
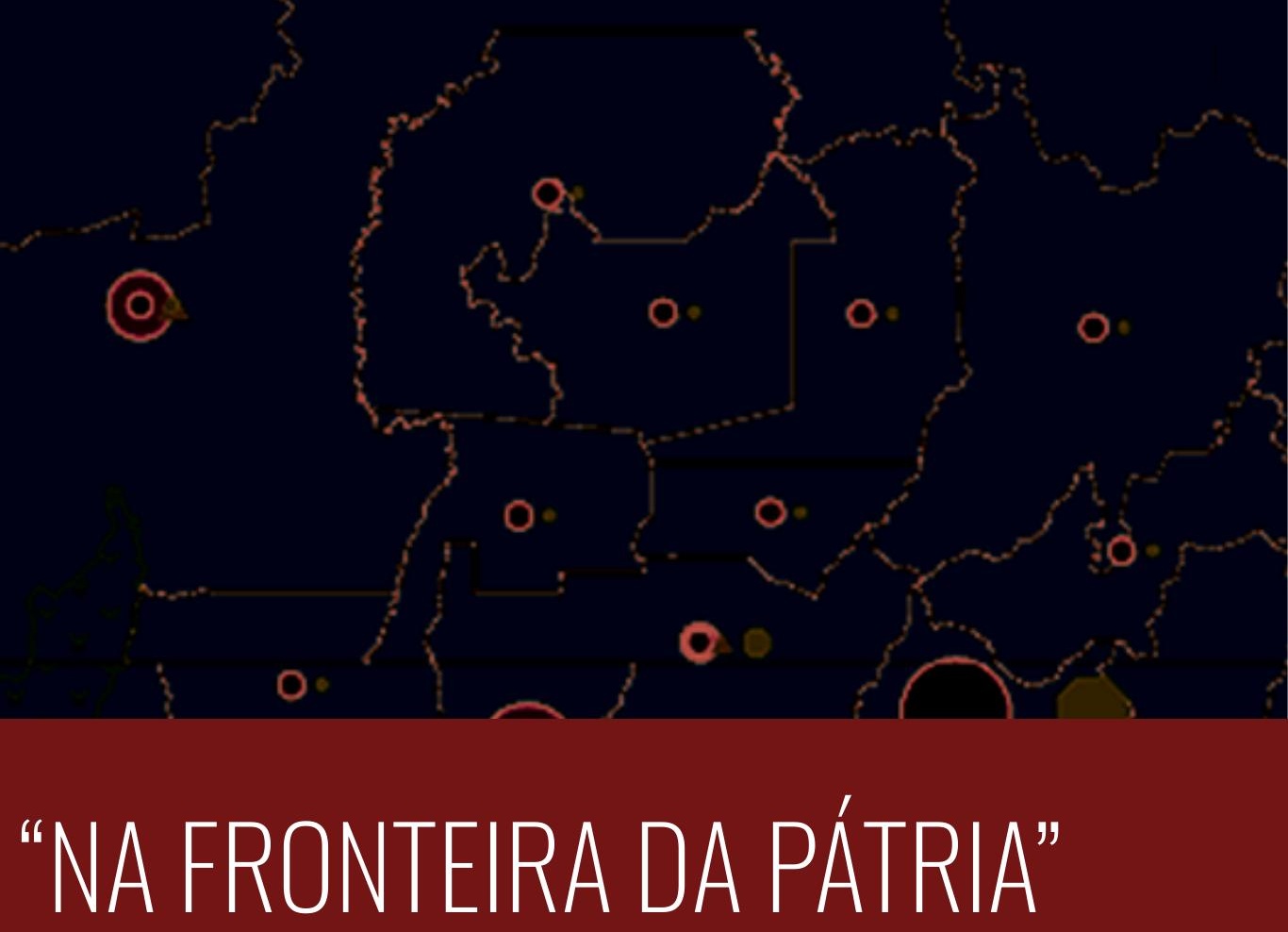

Movimentos sociais do campo em Rondônia, conflito, protesto e participação

Afonso Maria das Chagas

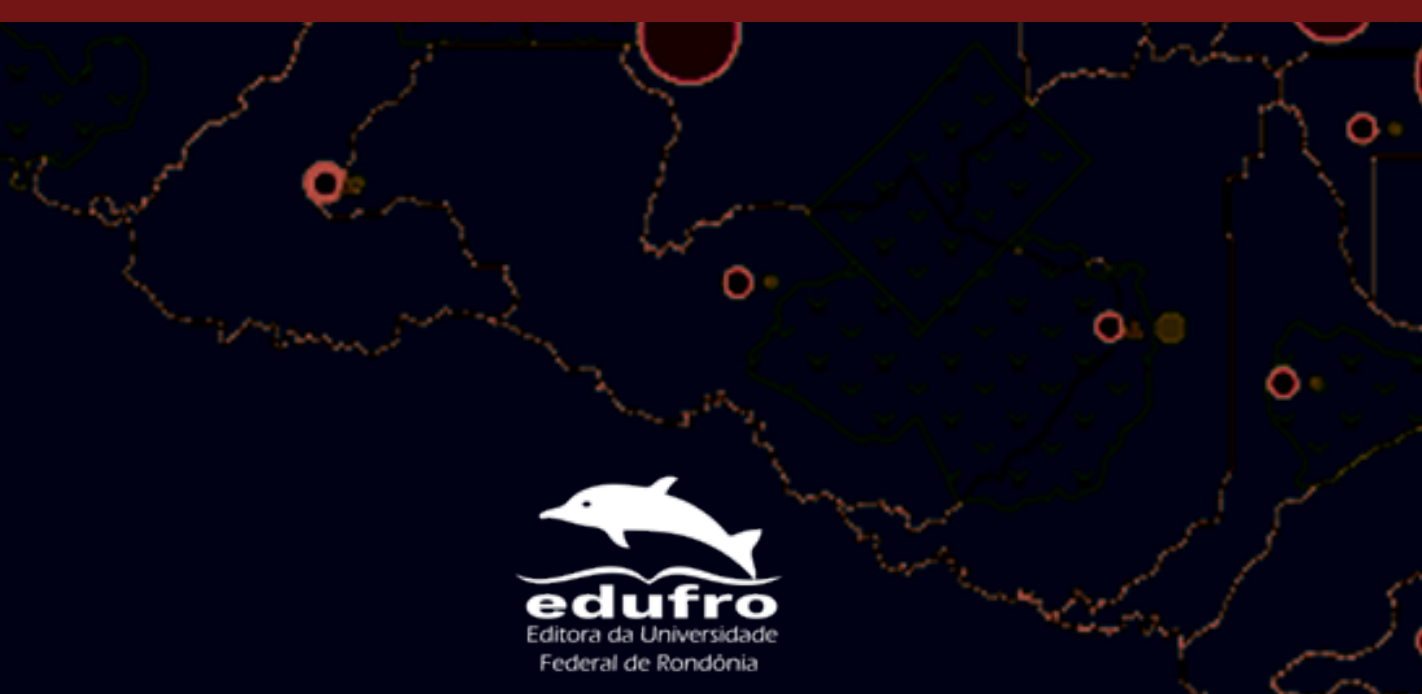


NA FRONTEIRA DA PÁTRIA

MOVIMENTOS SOCIAIS DO CAMPO

EM RONDÔNIA - CONFLITO,

PROTESTO E PARTICIPAÇÃO 
Reitor Ari Miguel Teixeira Ott

Vice-Reitor José Juliano Cedaro

EDITORA DA UNIVERSIDADE FEDERAL DE RONDÔNIA

$\begin{array}{ll} & \text { CONSELHO EDITORIAL } \\ \text { Presidente } & \text { Lou-Ann Kleppa } \\ & \text { Ariana Boaventura Pereira } \\ \text { Carlos Alexandre Trubiliano } & \text { Eliane Gemaque Gomes Barros } \\ & \text { Gean Carla Silva Sganderla } \\ \text { Leandro Soares Moreira Dill } & \text { Márcio Secco } \\ & \text { Marli Lúcia Tonatto Zibetti } \\ & \text { Pedro Ivo Silveira Andretta } \\ & \text { Ricardo Gilson da Costa Silva } \\ & \text { Xênia de Castro Barbosa }\end{array}$

Editora Filiada
Edufro - Editora da Universidade Federal de Rondônia BR 364, Km 9,5
Campus Unir
76801-059 - Porto Velho - RO
Tel.: (69) 2182-2175
www.edufro.unir.br edufro@unir.br




\section{NA FRONTEIRA DA PÁTRIA MOVIMENTOS SOCIAIS DO CAMPO EM RONDÔNIA - CONFLITO, PROTESTO E PARTICIPAÇÃO}

Afonso Maria das Chagas

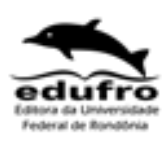

Porto Velho - RO 
(C) 2020 by Afonso Maria das Chagas

Esta obra é publicada sob a Licença Creative Commons Atribuição-Não

Comercial 4.0 Internacional.

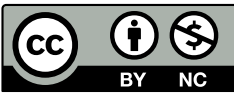

Capa:

Vitoria Gonçalves Morão

Revisão:

Dra. Jeane Mari Spera

Projeto gráfico:

Edufro - Editora da Universidade Federal de Rondônia

Diagramação:

Guilherme André de Campos

Impressão e acabamento:

Seike \& Monteiro Editora

Aprovado no Edital 02/2018/EDUFRO

Dados Internacionais de Catalogação na Publicação

Fundação Universidade Federal de Rondônia (UNIR)

Ficha Catalográfica elaborada pela Biblioteca Central da UNIR

C433f Chagas, Afonso Maria das.

Na fronteira da Pátria: movimentos sociais do campo em Rondônia - conflito, protesto e participação. / Afonso Maria das Chagas. - Porto Velho, RO: EDUFRO, 2020.

223 p; il.

ISBN: 978-65-87539-25-6 (físico)

ISBN: 978-65-87539-14-0 (digital)

1. Processos participativos. 2. Colonização. 3. Movimentos agrários. 4. Direitos e garantias. I. Titulo. II. Fundação Universidade Federal de Rondônia.

CDU 332.3(811.1):34 


\section{AGRADECIMENTOS}

Vivemos tempos em que até reconhecer tem se tornado um ato subversivo e revolucionário. Agradecer é uma forma genuína de reconhecer. Esta proposta carrega consigo muitas condicionantes, e não teria sido possível sem os Professores Dr. Fábio Rychecki Hecktheuer e Professor Dr. Alfredo Gugliano, pela dedicação, amizade, amor à Pesquisa e ao Ensino. De igual forma, esta gratidão estende-se à Universidade Federal de Rondônia e a todo apoio prestado.

No percurso, as formas de amizade, orações, motivação, ternura, amor e cumplicidade... Assim entendo e reconheço, na forma de sentimento, aquilo que se personifica na pessoa de minha amada. Gratidão incondicional a você, Cleo Leandra.

Aos que, de forma mais direta, intensos na cumplicidade, contribuíram na realização deste projeto, através do diálogo reflexivo, dos debates, das oportunidades gestadas em tantos compromissos junto aos setores populares, organizações e movimentos sociais: Ruben Siqueira, Paulo César, Jadir de Morais, Adilson Machado, Nancy Cardoso, Maria Petronilia, entre tantos e entre tantas.

Confessa gratidão aos Movimentos Sociais do Campo de Rondônia, militantes e lideranças, reafirmando de forma intensa a amplitude do conceito de luta, cidadania e democracia. Ainda que excluídos histórica e sistematicamente da palavra e dos direitos, insurgem, combatem e irrompem silêncios, cegueiras e o arbítrio hospedado em tantos poderes instituídos. Nesses coletivos, enxergo e agradeço a todos que me estenderam a mão e o olhar de coragem, respeito e companheirismo. Deles e delas, sou aprendiz. Os testemunhos dados, nas lutas cotidianas no Estado de Rondônia, são referência de esperança, transformada em movimento, de quem "faz a roda girar".

Enfim, a todos aqueles e aquelas que, na fala e no silêncio, mantiveramse presentes, na ajuda construtiva, no suporte emocional, nos encontros e abraços que marcaram e marcam a amizade e a parceria.

A Deus, sobretudo...... 

Um homem, uma família, expulsos de suas terras, esse veículo enferrujado arrastando-se e rangendo pela estrada rumo ao Oeste. Perdi as minhas terras; um trator, um só, arrebatou-as. Estou sozinho e apavorado. E uma família pernoita numa vala e outra família chega e as tendas surgem. Os dois homens acocoram-se no chão e as mulheres e as crianças escutam em silêncio. Aqui está o nó, ó tu que odeias as mudanças e temes as revoluções. Mantém esses dois homens apartados; faze com que eles se odeiem, receiem-se, desconfiem um do outro. Porque aí começa aquilo que tu temes. Aí é que está o germe do que te apavora. É o zigoto. Porque aí transforma-se o "Eu perdi minhas terras"; uma célula se rompe e dessa célula rompida brota aquilo que tu tanto odeias, o "Nós perdemos nossas terras". Aí é que está o perigo, pois que dois homens nunca se sentem tão sozinhos e abatidos como um só. $\mathrm{E}$ desse primeiro "nós" nasce algo muito mais perigoso: "Eu tenho um pouco de comida" mais "Eu não tenho nenhuma". Quando a solução desta soma é "Nós temos um pouco de comida”, aí a coisa toma um rumo, o movimento passa a ter um objetivo. Apenas uma pequena multiplicação, e esse trator, essas terras são nossas. Os dois homens acocorados numa vala, a pequena fogueira, a carne que se cozinha numa frigideira comum, as mulheres caladas, de olhos vidrados; atrás delas as crianças, escutando com o coração palavras que seu cérebro não abrange. A noite desce. A criança sente frio. Aqui, tome esse cobertor. É de lã. Pertenceu à minha mãe - tome, fique com ele para a criança. Sim, é aí que tu deves lançar a tua bomba. É este o começo da passagem do "Eu" para o "Nós" 



\section{LISTA DE ABREVIATURAS E SIGLAS}

ACARAM - Articulação Central de Associação Rural de Ajuda Mútua ADCT - Ato das Disposições Constitucionais Transitórias

BDTD - Banco Digital de Teses e Dissertações

CNDH - Conselho Nacional de Direitos Humanos

CPDA - Curso de Pós-Graduação em Desenvolvimento, Agricultura e

Sociedade

CNS - Conselho Nacional dos Seringueiros

CPT - Comissão Pastoral da Terra

EFAs - Escolas Família Agrícola

FETAGRO - Federação dos Trabalhadores da Agricultura de Rondônia FHC - Fernando Henrique Cardoso

GAINSA - Guaporé Agro-Industrial S/A

GEBAM - Grupo Executivo do Baixo Amazonas

GETAT - Grupo Executivo de Terras do Araguaia/Tocantins

GETSOP - Grupo Executivo para as Terras do Sudoeste do Paraná

GRET - Grupo de Trabalho de Regulamentação do Estatuto da Terra

INCRA - Instituto Nacional de Colonização e Reforma Agrária

LCP - Liga dos Camponeses Pobres

MAPA - Ministério de Agricultura, Pecuária e Abastecimento

MCC - Movimento Camponês Corumbiara

MDA - Ministério do Desenvolvimento Agrário

MEAF - Ministério Extraordinário para Assuntos Fundiários

MPA - Movimento dos Pequenos Agricultores

MST - Movimento dos Trabalhadores Rurais Sem-Terra

NAEA - Núcleo de Altos Estudos Amazônicos

OAN - Ouvidoria Agrária Nacional

ONG - Organização não governamental

PAD - Projeto de Assentamento Dirigido

PIC - Projeto Integrado de Colonização

PNRA - Progrma Nacional de Reforma Agrária 
PPG - Programa de Pós-Graduação

PT - Partido dos Trabalhadores

RIUNIR - Repositório Institucional da Universidade Federal de Rondônia SIPRA - Sistema de Informações de Projetos de Reforma Agrária

SR - Superintendência Regional

SUDAM - Superintendência do Desenvolvimento da Amazônia

UDR - União Democrática Ruralista

UFRJ - Universidade Federal do Rio de Janeiro

UFRGS - Universidade Federal do Rio Grande do Sul

UFSC - Universidade Federal de Santa Catarina

UFPA - Universidade Federal do Pará

UNB - Universidade Nacional de Brasília

UNIR - Universidade Federal de Rondônia 


\section{SUMÁRIO}

13

PREFÁCIO

15 INTRODUÇÃO

19 1. MOVIMENTOS SOCIAIS DO CAMPO: PERCURSO CONTEXTUALE LOCALIZAÇÃO DO DEBATE

201.10 estado da questão: os movimentos sociais na perspectiva teórica e acadêmica

301.2 Os intérpretes da questão agrária e dos movimentos sociais do campo

321.3 A centralidade da questão agrária como tópico emblemático para a compreensão da realidade social e política

431.4 A localização do debate: movimentos sociais e questão agrária em Rondônia

53 2. ESTADO E QUESTÃO AGRÁRIA: RELEITURAS POLÍTICAS E DIÁLOGOS COMPLEMENTARES

532.1 Antonio Gramsci e a questão meridional

592.2 José Carlos Mariátegui e a "Questão peruana"

632.3 Raymundo Faoro e os "donos do poder"

692.4 Contraponto analítico 1: patrimonialismo ou escravidão?

742.5 Diálogos complementares: dimensões no agrário no contexto político

822.6 Abordagens aproximadas: breve sumário analítico

872.7 Contraponto analítico 2: o mito da ausência do Estado

99 3. MOVIMENTOS E CENÁRIOS: PROCESSOS DE ENFRENTAMENTO E RESISTÊNCIA NAS LUTAS AGRÁRIAS EM RONDÔNIA

$100 \quad 3.1$ Pela posse e ocupação: ação e reação nas lutas sociais dos anos 1970

106 3.2 A década da destruição e as lutas de 1980 a 1995 
1163.3 Os processos de resistência e a ação articulada

1263.4 Mapeando a pesquisa: formas de abordagem e localização temporal

1313.5 Identificando as origens e as formas de organização coletiva

1383.6 Localizando a ação: repertórios e campos de interlocução

1483.7 Objetivando a ação coletiva: as "bandeiras de luta" dos movimentos sociais do campo

1513.8 Avaliando os resultados: autocompreensão da relação movimentos sociais e Estado nos "governos populares" (2003-2016)

157 4. MOVIMENTOS SOCIAIS DO CAMPO E PROCESSOS PARTICIPATIVOS: RELAÇÕES EM MOVIMENTO

1594.10 processo de redemocratização no contexto dos Projetos de colonização

1644.2 Pressupostos da relação Estado-movimentos sociais do campo: condicionantes e variáveis

1694.3 A percepção desde dentro: o Estado autocompreendido e a percepção do conflito

1754.4 Conexões participativas entre Estado e movimentos: disputas e arranjos num novo "espaço público"

1864.5 Movimentos sociais do campo e a inserção estatal: entre aporias e perspectivas

1924.6 Dinâmicas participativas e oportunidades políticas: "da ação ao movimento"

2024.7 Movimentos sociais e racionalidade política - legitimação pelo procedimento ou pela participação: desafios

208 Conclusão

211 Referências

223 Sobre o autor 


\section{PREFÁCIO}

É com alegria e muita satisfação que recebo o convite do Professor Doutor Afonso Maria das Chagas (UNIR) para prefaciar uma das suas recentes pesquisas, que teve como produto a presente obra, intitulada " $\mathrm{Na}$ fronteira da Pátria': movimentos sociais do campo em Rondônia, conflito, protesto e participação".

Faz-se, em sua obra, uma abordagem analítica dos movimentos sociais, decorrentes do processo de colonização do Estado de Rondônia, a partir da década de 1970. Colocam-se em evidência os elementos estruturais que pressupunham tal empreendimento estatal. No entanto, busca-se detectar igualmente outros componentes expressos ou ofuscados no interior de tal processo.

De um canto a outro do Estado, a colonização encontrou resistências, emergiram situações de conflitos, desvelaram-se equívocos, trazidos à margem por diversas e distintas formas de mobilização social, algumas organizadas, outros pontuais, contudo, sempre em dinâmica de movimento.

A ação coletiva desses grupos e movimentos sociais é, por sua vez, uma ação dinâmica, que se constitui e se reconstitui no dinamismo histórico e contextual das próprias demandas, e no contexto das alterações políticas e econômicas. Por vezes, a ação direta deu lugar à ação política e, por isso, se fala no decorrer do trabalho das disputas e controvérsias havidas também no interior das dinâmicas da ação coletiva.

De tal forma, aponta este trabalho para uma leitura política da relação entre Estado e movimentos sociais do campo, que desvela também os traços marcantes e profundos de nossa constituição social, política e econômica.

O discurso do desenvolvimentismo atual, tangenciado pela retórica do agro, do expansionismo do capital agroexportador, dos monocultivos, da reconcentração da propriedade e da grilagem de terras públicas, nada mais são do que um retrato perverso de um sistema originário de colonização dirigida. Assim, abordar a questão agrária, as resistências camponesas e o 
dirigismo estatal é colocar sob suspeita tudo o que significou o empreendimento da colonização, seus pressupostos, seu projeto e horizontes.

É em torno dessas contradições e sob o enfoque desses sujeitos sociais que, ao longo do período, demandaram e demandam pela atenção e responsabilidade do Estado, que este trabalho se exsurge.

Salienta-se que a cientificidade encontrada neste estudo garante a universalidade da obra para utilização como fonte de pesquisa e de dados para os diversos campos do saber, em especial, as ciências sociais.

Prof. Dr. Fabio Rychecki Hecktheuer Reitor da Faculdade Católica de Rondônia 


\section{INTRODUÇÃO}

A terceira estrofe do hino de Rondônia é emblemática. Após decantar a saga dos novos bandeirantes, das sentinelas avançadas e dos destemidos pioneiros, a letra nos faz lembrar que:

Desta fronteira de nossa Pátria, Rondônia trabalha febrilmente, nas oficinas e nas escolas, a orquestração empolga toda gente.

A ideia de fronteira nos remete aos limites, que podem inclusive simbolizar as limitações, ausências e esquecimentos. A perspectiva, entretanto, perpassa pela lógica do nada existe para a lógica de um destino manifesto: salvar a pátria, fortalecer e integrar a nação. Com um só golpe retórico, resolvem-se dois problemas: a superação dos “obstáculos", inclusive humanos, e a efetivação do progresso, a qualquer custo. $\mathrm{O}$ indígena, o quilombola, o ribeirinho e os povos tradicionais não encontram seu lugar, nem nesse texto, muito menos nesse contexto. Mas também o colono migrante não se assemelha muito a esse bandeirante destemido, nas "paragens do poente". Da ausência à contestação, emerge, pois, a questão da terra e dos grupos e movimentos sociais do campo. Há vidas que não se engalanam para além da poesia.

A questão da terra está entranhada na constituição social, econômica e política do Estado de Rondônia. Tal fenômeno, contanto, é dimensionado por uma pluralidade de sentidos nem sempre dizíveis, nem sempre visíveis, muitas vezes retoricamente desvirtuado. Desde a perspectiva de seus originários habitantes, indígenas e quilombolas, aos migrantes de todas as levas, coincidiu e coexistiu um processo de intensa e paradoxal percepção. Tal processo, em outro rumo, foi intensamente delineado e tangido pela ação estatal, materialmente legitimando e legitimado por claros e patrimoniais interesses, abstrata ou ideologicamente autenticada por retóricas e oficiais narrativas. O sentido da terra/território, então, visualiza-se como uma ideia em movimento.

A compreensão de movimento caracteriza, em essência, um referencial dialético de sentido e interpretação da realidade. A dinâmica dos movimentos sociais expressa e sinaliza tal dimensão, seja frente às instituições, seja no 
horizonte das transformações sociais, seja na forma como se constituem e se desenvolvem no campo contraditório da realidade. Mas os movimentos sociais também territorializam o campo da construção social, pontuada pela atuação e reconstituição dos sujeitos históricos e coletivos, em sua complexidade, tensionamento e contradições. Os movimentos sociais do campo referenciam o ponto fulcral do presente trabalho, em especial no contexto das lutas agrárias e na relação com o Estado.

A ação desses movimentos sociais do campo, sobretudo na luta pelo acesso à terra, tem sido histórica e sistematicamente relegada ao compartimento retórico da subversão, do atraso, como se fosse "coisa do passado". Esvazia-se, assim, de tal temática, o seu conteúdo político e social, ou seja, republicano e democrático.

No contexto mais próximo da colonização em Rondônia, a questão agrária revela não só a implementação de uma política de Estado ou de governo, mas, ainda, as lógicas do movimento de expansão do capital, embutidas na política pública, o direcionamento estatal e suas reais finalidades, assim como a questão social, em seus limites e possibilidades. Por outro lado, as resistências, enfrentamentos e atuações dos movimentos sociais do campo revelaram igualmente o contraditório da questão, desvelando tais contradições, a retórica do desenvolvimentismo e da integração, e os efeitos decorrentes.

É sobre essa dinâmica que este trabalho se projeta, tanto no plano da revisão teórica sobre o tema, no plano das justificativas retóricas instituídas, quanto no plano dos processos sociais que contextualizam o surgimento e a ação dos movimentos sociais do campo em Rondônia. Ilustra esse debate a pesquisa de campo realizada, buscando investigar origens, contexto e formas de interação dos movimentos sociais do campo e Estado. Descortina-se aqui um cenário complexo e revelador dos mecanismos e instrumentos de participação coletiva, novos espaços públicos de atuação e organização. Em tal processo, elementares questões são postas: podem os movimentos sociais ser expressão de transformação e rupturas? Superam a lógica do paternalismo ou da domesticação 
institucional? Sinalizam para um verdadeiro protagonismo social ou foram tragados pelo descompasso histórico?

Mas a pesquisa também descortina a autocompreensão do Estado. E, desvela, ao fim, uma complexa teia de relações, suscitando debate ou problematizando uma crucial questão que muito revela do nosso processo histórico-político, desvendando igualmente continuidades e insistências.

No primeiro capítulo, busca-se reconstituir o debate no plano teórico, reposicionando a temática inclusive no plano da pesquisa e compreensão da questão. Há um retrato significativo e simbólico, na presença/ausência da temática no plano acadêmico, suas interfaces, suas compreensões e sentidos de fundo.

No segundo capítulo, acessam-se os argumentos, em plano de revisão, que anteparam a centralidade da questão agrária e o papel constitutivo e garantidor do Estado. Aqui se vislumbram os elementos paradoxais de um sistema de colonização instituída e mantida, condicionando a dinâmica organizacional do poder político, tendo por base o regime da grande propriedade, culminando na apropriação estatal de tais interesses.

No terceiro capítulo, traz-se o itinerário e o contexto histórico das lutas sociais do campo em Rondônia, sua genealogia e a ressignificação da questão agrária como luta política. E, nesse contexto, também, apresentar-se-á a sistematização da pesquisa realizada, como forma complementar do debate teórico realizado.

No quarto capítulo, a partir da observação sistematizada pela pesquisa, buscar-se-ão demonstrar as percepções, conexões e inter-relações entre Estado e movimentos sociais do campo, em Rondônia. Analisa-se, aqui, o fenômeno da participação em movimento. 



\section{MOVIMENTOS SOCIAIS DO CAMPO: PERCURSO CONTEXTUAL E LOCALIZAÇÃO DO DEBATE}

Para além do amplo debate que vem sendo feito acerca dos movimentos sociais, como fenômeno tanto no campo das Ciências sociais quanto da Ciência política, a ideia central do recorte sobre os movimentos sociais do campo implica um esforço cognitivo e contextualizado. Trata-se de buscar compreender tal fenômeno, que se contextualiza como uma realidade pouco ou mal visibilizada no campo da análise da ação coletiva. Em regra, há muita literatura acerca dos movimentos sociais, mas em uma delimitação marcadamente no fenômeno urbano das ações coletivas. Assim, de início, esclarece-se que o meio rural, como território de análise, torna-se condição contextual de possibilidade para o outro recorte necessário.

O contexto histórico-político de Rondônia, compreendido aqui, especificamente, no período que vai da colonização até os dias de hoje, implementou-se sob uma perspectiva ou racionalidade ao mesmo tempo óbvia e ambígua. Óbvia, pelo fato de ser a política de colonização, claramente uma política de Estado e de governo, sob a forma de uma "ação dirigida". Ambígua, porque ocultou em suas estratégias geopolíticas, articulações e pragmatismo, uma disfarçada proposta de integração nacional e de desenvolvimento. A narrativa, no contexto, compunha-se de uma imagem e retórica onde se desenhava a "solução dos conflitos do campo", em alta evidência, nas regiões centro-sul do Brasil. Ambígua também pelo fato de que, ao se apresentar como resposta aos conflitos, gerou outros conflitos, que insistem em permanecer até os dias de hoje. Esse é um segundo recorte, indispensável, para contextualizar o presente estudo.

Dessa forma, a proposta volta seu olhar inicial, a fim de perceber o "estado da questão", ou seja, como se encontra o debate, no Brasil, acerca dos movimentos sociais do campo, ou movimentos sociais rurais, nas últimas décadas.

Agrega-se a isso um olhar mais atento sobre alguns elementos de abordagem, interpretação e compreensão sobre o tema. Incorpora-se, nessa 
dinâmica, ainda, uma rápida apresentação sobre a genealogia das lutas sociais do campo, em Rondônia. Considera-se, enfim, que há elementos surpreendentes que anunciam, no processo, situações de permanência e rupturas, que também se faz necessário desvelar, a fim de compreender em quê e por quê a dimensão de participação política dos movimentos sociais do campo foi e tem sido crucial no entendimento da formação político-social e econômica do Estado de Rondônia.

\subsection{O ESTADO DA QUESTÃO: OS MOVIMENTOS SOCIAIS NA PERSPECTIVA TEÓRICA E ACADÊMICA}

São muitas as análises que concordam em reconhecer que os movimentos sociais são imprescindíveis na vida social, pois sua presença ou ausência são balizas que constituem, determinam e dão sentido à ação coletiva. Seja na luta por direitos e garantias, seja nas formas de resistência à exclusão, a articulação dessas ações coletivas vem se reconstituindo e ganhando novas configurações, novos contornos sociais (McAdam, Tarrow e Tilly, 2009; Alonso, 2009; Touraine, 1998; Castells, 2013; Gohn, 2014; Scherer-Warren, 2006).

Trata-se do desenvolvimento de forças políticas, consideradas à luz de tais análises, imprescindíveis para a vida social ante a ordem constituída. Contudo, tais forças podem ser capturadas pelo Estado, que então reconduz as agendas políticas e mesmo o "capital simbólico" de tais ações para a esfera jurídica e administrativa. A constatação de tal possibilidade denota, portanto, que na lógica da ação coletiva a predominância do enfoque em somente um desses aspectos, seja ele jurídico, seja político-administrativo, pode resultar na armadilha de reprodução da própria estrutura social dominante. Manifesta-se, assim, sob um prisma mais ampliado, como é complexa a relação entre movimentos sociais e Estado (Dal Maso, 2004).

As lutas desempenhadas pelos movimentos sociais do campo, no Brasil, implicam ainda, enquanto ação coletiva organizada, na esfera da participação e dinamização de um novo espaço de atuação. Tal espaço vai constituindo-se como um campo diferenciado de atuação, impactando seja 
na construção ou resgate da cidadania, seja na efetivação de direitos, muitas vezes somente formalmente assegurados. Ao criar condições para que as demandas suscitadas se tornem públicas, no espaço da institucionalidade, os movimentos tornam visíveis, ou na sua gênese, ou no que caracteriza suas formas de ação, a contestação da realidade donde se inserem. Criam, assim, instrumentais políticos de denúncia, reivindicação, bem como potencializam a efetivação de direitos.

A luta pela terra, materializada pelos movimentos sociais do campo, desvela, antes de tudo, a constatação de que as relações sociais no campo refletem a história inacabada da questão agrária, contundentemente marcada pela permanência de relações coloniais. Entrementes, essa mesma luta enfatiza o protagonismo desses movimentos sociais nas suas diferenciadas formas de resistência e mobilização. Muitas vezes, tais lutas são talhadas no campo do enfrentamento onde se permeiam conflitos sociais e políticos, demandando por um esforço de observação mais atento, para além das interpretações teóricas prontas ou descuidadamente adaptadas.

Nas últimas décadas, em boa parte a ação coletiva dos movimentos sociais do campo fizeram emergir alguns elementos de compreensão que, ao invés de reduzir a perspectiva de atuação de tais movimentos somente no campo agrário, ampliava o horizonte dessa percepção. Por essa razão se analisa, sobretudo a partir dos anos 2000, se tais movimentos incorporaram ou não as ideias de democracia e cidadania integral, segundo as quais o "direito à terra”, como outros direitos, são elevados ao patamar de direitos fundamentais. A hipótese é que isso ocorreu e, dessa forma, tornou-se possível, projetar toda uma carga simbólica de que, para além dos direitos (cidadania social), se incrementasse também o reconhecimento das organizações como instrumentos de participação (cidadania política).

Em perspectiva mais orgânica (interna), a organização e fortalecimento dos movimentos sociais do campo contribuíram para a ideia de "politização da própria sociabilidade" (Scherer-Warren, 2011). Ou seja, a dinâmica de alavancar a solidariedade e a prática cooperativa numa dimensão política. É nessa prática que a "resistência" se efetiva como "R-Existência", conforme Carlos Walter Porto-Gonçalves (2006). Na prática, isso foi traduzido em 
novas relações societárias, com experiências práticas de democracia interna, autonomia perante o Estado, captação e influência na opinião pública.

Há que se ressalvar, contudo, que as experiências de "absorção" - sob a forma de cooptação de muitas lideranças que migraram para as esferas estatais, assim como um comportamento fixado mais no movimento de institucionalização das instâncias e movimentos - arrefeceram, em muito, essa projeção. No conjunto, o certo é que, a partir do período de transição democrática, os movimentos sociais do campo enveredaram na construção de uma nova - ou outra - "arena de atuação", principalmente para o Estado. Ao ressignificar sua atuação, com múltiplas formas de interação, manteve-se a questão agrária no debate público, gerando, nessas novas formas de atuação, um potencial emancipador, em constante processo de construção e, portanto, de diferenciação.

A especificidade do fenômeno aponta para a necessidade de rever os paradigmas de análise e interpretação dos movimentos sociais do campo. As leituras totalizantes acerca de um imaginário político, que concebem os processos de transformação em termos globais ou estruturais, precisam ser repensadas. Imaginar que tais mudanças se processam por um único eixo de luta, de forma hegemônica, é assingelar um universo de sentidos. A dinâmica de interação entre movimentos sociais e Estado, aliás, é dinâmica, e no dinamismo se refaz seguidamente. Assim, os processos de participação e de transformação política requer observar as rupturas, as brechas, as microrrevoluções no cotidiano, ressituando sempre as possibilidades e os limites da ação coletiva, nos casos específicos (Scherer-Warren, 1987).

A pesquisa voltada para o campo dos movimentos sociais ganha espaço também no meio universitário, através de programas de pós-graduação, pelo país. No entanto, cabe o registro das diferenças de abordagens, na perspectiva regional e na perspectiva da tradição que alguns programas têm sustentado na abordagem do assunto. Isso configura, em grande parte, a centralização dos investimentos em pesquisa em regiões tradicionais $(\mathrm{Su}-$ doeste e Sul), denunciando, por outro lado, para além dessa concentração, determinado desconhecimento, seguindo de omissão em investimento em 
ensino, pesquisa e extensão, a regiões historicamente relegadas ou marginalizadas, em especial, a região norte.

Entre os programas de pós-graduação no Brasil, destacam-se alguns, nas pesquisas orientadas para os movimentos sociais. Na Universidade Nacional de Brasília (UNB), sobretudo na área do Direito, as linhas de pesquisa "Sociedade, Conflito e Movimentos" e "Processos Institucionais de Administração de Conflitos e Acesso à Justiça”, com acento aqui para o projeto "Direito achado na rua", apresentam importantes pesquisas e contribuições acerca dos movimentos sociais. Na Universidade Federal de Santa Catarina (UFSC), na área de Ciências Sociais e Sociologia Política, há uma linha de pesquisa historicamente identificada com os estudos dos movimentos sociais: "Movimentos Sociais, Participação e Democracia”. Na Universidade Federal do Rio de Janeiro (UFRJ), em especial no Curso de Pós-graduação em Desenvolvimento, agricultura e Sociedade (CPDA), ligado à área de Filosofia e Ciências Humanas, há uma das mais destacadas instâncias de pesquisa sobre o tema. Destaca-se entre as linhas de pesquisa: "Estudos de Cultura e Mundo rural", "Conflitos, Movimentos sociais e Representação política”, "Desigualdades e Promoção da Cidadania”. Na Universidade Federal do Rio Grande do Sul (UFRGS), a temática é abordada pelo Instituto de Filosofia e Ciências Humanas (PPGs Sociologia e História), em algumas linhas de pesquisa como: "Sociedades, Participação social e Políticas Públicas”, "Sociedade, Ruralidade e Ambiente" "Violência, conflitualidades, Direito e Cidadania”. No campo específico do PPG em História, destaque para as seguintes linhas de pesquisa: "Relações sociais de Dominação e Resistência", "Minorias sociais, estigmatização, discriminação e Resistência".

No contexto da Amazônia, nos programas de pós-graduação da Universidade Federal do Pará (UFPA), a temática é abordada em várias áreas: Sociologia, Antropologia, Filosofia, Ciência Política, Ciências Sociais e História. Entre as linhas de pesquisa, se destacam: "Ações Públicas e Coletivas, Território e Ambiente", "Organização e Gestão de Território", "Processos Sociais de Territorialização, Direitos das Populações Tradicionais e Conflitos Sociais”, “Migrações, Diásporas e Etnicidades”, "Povos Indígenas 
e Populações Tradicionais”. Devido ao tratamento específico dado à temática dos movimentos sociais na Amazônia, em especial aos movimentos socioterritoriais, há de se destacar o Núcleo de Altos Estudos Amazônicos (NAEA), com quase 50 anos de existência e incentivo às pesquisas voltadas para a realidade amazônica.

No Amazonas, a Universidade Federal do Amazonas aborda pesquisas e análises sobre os movimentos sociais nos programas de pós-graduação em Antropologia Social, Educação, Geografia e História. Merecem destaque algumas linhas de pesquisa vinculadas a tais programas: "Amazônia indígena, Povos Tradicionais, Política e Territorialidade", "Estudos migratórios e Políticas territoriais", "Nova Cartografia Social da Amazônia - PNCSA". A temática, em específico sobre os movimentos sociais, é tratada no PPG em História, destacando as seguintes temáticas: "Políticas, Instituições e Práticas sociais", "Migrações, Trabalho e Movimentos sociais”.

$\mathrm{Na}$ Universidade Federal do Acre, a temática dos movimentos sociais é recepcionada e abordada no mestrado em Desenvolvimento Regional, com destaque na seguinte linha de pesquisa: "Movimentos sociais, Questão agrária e Desenvolvimento agrário”.

É possível observar que, no final da década de 2000, a perspectiva de atuação dos movimentos sociais do campo, para além da questão do acesso à terra (reforma agrária), vai perdendo espaço nas pesquisas para outras preocupações. Põe-se em evidência a questão ambiental e agroecologia, que conjuntamente com a questão das práticas educativas, sobretudo em nível das pedagogias do campo, passa a ganhar cada vez mais destaque.

Na sistematização dos dados recolhidos sob o mesmo parâmetro, no Repositório de Teses e Dissertações da Universidade Federal de Rondônia, percebe-se algumas alterações relativas ao trato acadêmico dado ao assunto. Reitera-se que os dados foram coletados junto ao sistema Riunir - Repositório Institucional da Universidade Federal de Rondônia. A busca principal pautou-se pelo verbete "movimentos sociais" e "movimentos sociais do campo", em um primeiro momento. Para filtrar ainda mais a busca, na perspectiva de demarcar a abordagem voltada para a questão abrangida, consultou-se as palavras-chave, dos resumos dos trabalhos publicados. 
$\mathrm{Na}$ tabela a seguir, expõe-se a sistematização feita do verbete "movimentos sociais do campo", no recorte temporal entre 2008-2017. Da pesquisa, resultaram 750 incidências. Dessas 750 incidências filtradas, ao analisar o tema e as palavras-chave, a busca chegou a 114 resultados que continham referências aos movimentos sociais do campo, ação coletiva, movimentos sociais rurais.

Tabela 1 - Temáticas abordadas (Repositório UNIR) - (2008-2017)

\begin{tabular}{|l|c|}
\hline \multicolumn{2}{|c|}{ Temáticas abordadas no Banco de Teses e Dissertação da Unir } \\
\hline \multicolumn{1}{|c|}{ Temáticas } & Repositório UNIR \\
\hline Questão ambiental, Reservas, Unidades de Conservação & 25 \\
\hline Agronegócio, mercado, pecuária, produção & 24 \\
\hline Agroecologia e produção alternativa & 14 \\
\hline $\begin{array}{l}\text { Sujeitos coletivos: indígenas, quilombolas, seringueiros, } \\
\text { ribeirinhos }\end{array}$ & 12 \\
\hline Territorialidade, território, geopolítica & 10 \\
\hline Assentamentos, agricultura familiar & 8 \\
\hline Educação do campo, Educação, pedagogia & 7 \\
\hline Hidrelétricas e Complexo do Madeira, atingidos & 6 \\
\hline Religiosidade & 2 \\
\hline Questão agrária & 3 \\
\hline Gênero, Mulher, juventude & 2 \\
\hline Literatura e movimentos sociais & 1 \\
\hline
\end{tabular}

Fonte: Própria Autoria com base no Repositório de Teses e Dissertações da UNIR, 2017

A temática ambiental apresenta-se como fator predominante nas escolhas, seguida da temática do agronegócio e da agroecologia. Uma parte da explicação pode ser encontrada pela procedência dos trabalhos. Dos 114 resultados obtidos, 43 são produções da Pós-Graduação em Administração, 45 produções da Pós-Graduação em Geografia, e 15 da Pós-Graduação em Desenvolvimento Regional, entre os mais referenciados. Conforme a Tabela 2, é importante observar como a questão relativa a assuntos dos movimentos sociais do campo e questão agrária estão relacionados (ou não) por áreas de estudo e pesquisa. 
$\mathrm{Na}$ perspectiva das Linhas de Pesquisa, os três principais programas, sobre os quais incidiu a sistematização dos dados, levaram a perceber que o enfoque de pesquisa pouco se volta para o fenômeno humano dos movimentos sociais, como tal. $\mathrm{O}$ direcionamento programático incide mais sobre questões de estratégia, gestão, governança e tecnologia (Administração), ambiente, desenvolvimento sustentável e políticas públicas (Desenvolvimento regional) e processos espaciais, gestão ambiental, território e sociedade na Pan-Amazônia (Geografia).

Por consequência, dos programas investigados, é no Programa de Geografia que se encontra uma maior proximidade com a temática, sem que, no entanto, se tenha evidenciado alguma pesquisa, especificamente, para os processos de enfrentamento e resistência dos movimentos sociais do campo, em perspectiva da geografia política. Dessa forma, as temáticas que sobressaem, em relação aos três programas de pós-graduação em destaque na Universidade federal de Rondônia, assim se retratam, pela pesquisa.

Tabela 2 - Temáticas abordadas (PPG/UNIR) - (2008-2017)

\begin{tabular}{|l|c|c|c|}
\hline \multicolumn{5}{|c|}{ Temáticas trabalhadas por PPG } \\
\hline $\begin{array}{c}\text { Questão } \\
\text { Ambiental, Resex, } \\
\text { Unidades de } \\
\text { Conservação }\end{array}$ & Agronegócio & $\begin{array}{c}\text { Agroecologia } \\
\text { e Agricultura } \\
\text { familiar }\end{array}$ \\
\hline Administração & 16 & 12 & 11 \\
\hline Geografia & 9 & 5 & 8 \\
\hline $\begin{array}{l}\text { Desenvolvimento } \\
\text { Regional }\end{array}$ & 3 & 5 & 4 \\
\hline
\end{tabular}

Fonte: Própria Autoria com base no Repositório de Teses e Dissertações da UNIR, 2017

Com base na coleta de dados, ao observar o período, é possível, em relação ao estado da arte da discussão sobre os movimentos sociais do campo em Rondônia, chegar a algumas breves constatações:

\section{Perspectiva política dos movimentos sociais do campo em} sua relação com o Estado. No período, pouca relevância é dada à pesquisa sobre os movimentos sociais do campo, em relação 
às ações de enfrentamento efetivadas por tais movimentos. $\mathrm{O}$ enfoque, substancial, volta-se para a dinâmica relacional desses processos, em relação à participação política ante o Estado ou instituições estatais. Além disso, há um enfoque evidenciado nas transformações, tanto do tempo quanto do espaço (dinâmicas territoriais), que envolvem, dinamizam ou, mesmo, criam obstáculos de atuação desses movimentos. Essa percepção é detectada, sobretudo, nas pesquisas e análises feitas, seja em matéria de publicação em instrumento em âmbito nacional (Scielo), seja em meio dos Programas de Pós-Graduação, fora do Estado.

2. Agenda ambiental e modelo de desenvolvimento. $\mathrm{Na}$ pesquisa no banco de dados, em sede regional (Repositório da Unir), aponta-se uma acentuação em relação à agenda ambiental e seus instrumentais, bem como a discussão voltada ao agronegócio e seus modos e meios de produção. Quanto à questão ambiental, ela é sobremaneira tratada na questão dos impactos, mas, também, por critérios bastante institucionais: sustentabilidade, governança ambiental, sobretudo nas perspectivas objetivas de proteção criadas na institucionalidade: Reservas, Parques e Unidades de Conservação. Sobre o Agronegócio, o enfoque da produção teórica e da pesquisa norteia sua perspectiva nas linhas de produção: pecuária de corte e leite, soja e lógica de comercialização. Há um indicativo de que, melhor amparado, o "movimento do agro", pela via da integração, suplanta ou incorpora em grande parte tanto a lógica de produção quanto a "ideologia" do campesinato e de suas lutas, nas primeiras décadas. Isso, em regra, pela via da “integração", impõe consensos, no meio rural e em sede da própria concepção de agricultura familiar.

3. Modos de produção alternativa e agroecologia. Nessa temática, a incidência pauta a ação dos movimentos sociais, em uma nova dinâmica de "fixação na terra", ou em imaginar e articular caminhos de sobrevivência dentro da lógica padrão do mercado 
e do consumo. As produções e pesquisas, neste campo, acentuam em muito, não só a experiência de povos ligados à questão territorial-tradicional, mas também o avanço das experiências de agroecologia, produção consorciada e agroflorestal etc.

4. Territorialidade e novos sujeitos coletivos. Se, por muitos anos, o campesinato e os movimentos sociais do campo (ou rurais) compreendiam apenas o público da agricultura familiar e dos "sem-terra", percebe-se, à luz da pesquisa, que cada vez mais vai se incorporando a questão territorial como forma de enfrentamento, resistência e forma de vida. Em âmbito amazônico, essa questão, em algumas regiões, sempre encontrou resistência, uma vez que os projetos de colonização colocavam frente a frente, em campo de disputa e luta, os colonos e migrantes e os povos originários: indígenas, quilombolas, ribeirinhos, extrativistas. A percepção dessa questão, como uma visão de conjunto, tem sido retratada na pesquisa como formas de resistência camponesa, incorporando esses diversos sujeitos coletivos diante da expansão do capital no agrário e fundiário, sob a forma e cultura do agronegócio na Amazônia.

5. Educação do campo, instrumental político. As pesquisas realizadas sinalizam, em muito, a dimensão instrumental da Educação como ferramenta a ser apropriada pelos movimentos sociais do campo. Essa perspectiva, no entanto, acontece de forma mais evidenciada nas temáticas produzidas e publicadas na Revista Scielo e BDTD do que no repositório da Universidade federal de Rondônia. É na perspectiva da Educação do campo que tem se travado um verdadeiro processo de mobilização e enfrentamento ao Estado, sobretudo em razão dos projetos de erradicar de vez, espacialmente, as "escolas rurais", como também, no projeto de implantar projetos de ensino médio pela "mediação tecnológica".

Cabe ressaltar que, na maioria dos trabalhos pesquisados, pouca referência se faz em relação à luta histórica, seja pela posse da terra, seja pela 
reforma agrária, seja, ainda, pelas vias da desapropriação ou arrecadação sumária (discriminação de terras públicas). Assim, quanto ao resgate histórico, o resultado é inexpressivo, ocorrendo sobretudo quando faz referência às lutas mais recentes, como o caso do "massacre de Corumbiara", de 1995. Não há registro, pois, de uma leitura política mais direcionada às lutas originárias pela terra, nos anos 1970 - 1990.

$\mathrm{Na}$ demarcação temporal investigada, pouca referência se faz à luta pela terra em si. $\mathrm{O}$ enfoque acaba direcionado mais às experiências localizadas, formas de produção e educação, como já salientadas. Aspecto a ser ponderado diz respeito ao fato de que, dos três programas de pós-graduação em destaque, dois deles (Administração e Desenvolvimento Regional), ainda que inserindo, como área de concentração, as possibilidades de enfoque sobre o assunto, isso não ocorreu, pelo viés, sobretudo, do enfoque institucional e tecnicista dado ao debate. No programa de pós-graduação em Administração, as linhas de pesquisa são: 1) Estratégia, Gestão e Tecnologia das Organizações, aqui, principalmente, à luz das motivações econômicas e socioambientais; 2) Governança, sustentabilidade e Amazônia, este inclusive delineando, em uma das suas linhas de pesquisa, a questão das "organizações e ações coletivas". O programa de pós-graduação em Geografia tem como área de concentração: "Ambiente e Território na Pan-Amazônia. Já o programa de pós-graduação em Desenvolvimento Regional e Meio ambiente traz como área de concentração: desenvolvimento sustentável e Diagnóstico ambiental.

Em relação, de forma generalizada, à escassez de produção sobre a temática dos movimentos sociais do campo, há que se considerar o fato de tais programas ainda não terem uma determinada tradição; são recentes. Em relação a outras regiões do Brasil, as temáticas dos movimentos sociais do campo são mais incidentes nas regiões com maior tradição nas pesquisas direcionadas para a questão agrária/fundiária, assim como para os conflitos, onde se expressa a ação coletiva dos movimentos sociais (regiões Sudeste, Sul e Nordeste). 


\subsection{OS INTÉRPRETES DA QUESTÃO AGRÁRIA E DOS MOVIMENTOS SOCIAIS DO CAMPO}

Naquilo que se refere à temática que recorta a discussão do presente trabalho, à luz também das pesquisas feitas nos bancos de dados, identifica-se um conjunto de pesquisadores brasileiros que, de certa forma, indicam a perspectiva de autores referenciais sobre o estado de debate da presente questão.

Movimentos sociais do campo. Uma das referências centrais, tendo como base uma perspectiva histórico-sociológica, é José de Souza Martins. Trata-se de um dos autores mais referenciados também em relação à questão na perspectiva das "fronteiras" (fronteira de expansão e fronteira pioneira). Há uma ampla margem de discussão e abordagem sobre os processos de colonização, avanço do capital e a questão indígena, no cenário amazônico. Em relação à questão dos movimentos sociais do campo, no contexto amazônico, importante a sistematização de Miguel Carter, em analisar sobretudo o papel do MST. O campesinato em suas múltiplas faces, no contexto amazônico, tem importante papel nas obras de Jean Hébette. Em plano geral, pelo acúmulo da produção e reflexão teórica, os movimentos sociais do campo, como tema acadêmico, aparece constantemente nas obras de Maria da Glória Gohn e Ilse Scherer-Warren. Há que se fazer referência, ainda, nessa perspectiva da ação coletiva, no contexto do campo amazônico, a Alfredo Wagner Berno de Almeida, Philippe Léna e Adélia Engrácia de Oliveira. Alfredo Wagner, íntimo conhecedor dos processos socioterritoriais amazônicos, oferece importantes chaves de leitura para se compreender os mecanismos de resistência e as perspectivas estratégicas de avanço do capital (agroestratégias). Léna e Oliveira organizaram importante produção sob forma de avaliação, com base na atuação dos sujeitos coletivos. Assim, esses pesquisadores pautaram a questão dos povos originários em relação à colonização, à dinâmica dos assentamentos, às formas e dinâmicas de produção, e à perspectiva do conflito em tais processos.

Questão agrária e Projetos de colonização. Esse é o campo de debate de farta literatura. Destacamos alguns autores que recorrentemente 
são referenciados. De certa forma os clássicos: Octávio Ianni, Bertha Becker e José de Souza Martins, Moacir Palmeira, Delma Pessanha Neves, para ficar em alguns. Na perspectiva de Rondônia, no contexto amazônico: Hervé Thery, Martin Coy, Philip Martin Fearnside, são pesquisadores que trabalham elementos mais estruturais dos projetos, numa perspectiva e olhar inclusive de fora, acerca desse fenômeno da década de 1970. Pesquisadores e analistas locais têm produzido importantes análises sobre os projetos de colonização, especificamente operacionalizados em Rondônia: Lenita Turchi, Maria Helena Henriques e Lilian Moser, com enfoque nos referidos projetos, ajudam a perceber as dinâmicas estruturais que moldaram nossa formação socioterritorial e política. Bernardo Mançano Fernandes e Klass Woortmann colocam em perspectiva os elementos de um campesinato amazônico.

Movimentos sociais, Estado e mediações: Em relação à dimensão dos processos interativos e participativos, na transversalidade da discussão proposta, faz-se destaque a alguns autores. Em relação ao alcance teórico do debate, recorre-se a Charles Tilly, Sidney Tarrow e Doug McAdam. No Brasil, essa discussão tem sido pautada insistentemente por Angela Alonso e Rebecca Abbers. No plano de análise mais contextualizado na Amazônia e em Rondônia, algumas importantes contribuições como: Miguel Carter, Delma Pessanha Neves, Gabriel Ondetti, Camila Penna de Castro, Lygia Sigaud, entre tantos. Apesar de tantas e valiosas referências, a ideia não é exaurir as referências para o debate. Outras tantas e de igual envergadura deixaram de ser aqui referenciadas. Muitas produções, principalmente na forma de dissertações e teses, pontuaram o debate, com profundidade e riqueza na análise. Apesar de tudo, é importante dimensionar a trajetória da presente pesquisa naquilo que lhe é característico, ou seja, a percepção de uma lacuna sobre o assunto, em âmbito de Estado. Sobremaneira, no campo da ótica política, é inédita a proposta de analisar o protagonismo dos movimentos sociais do campo na sua relação com o Estado. Assim como é inédito o desafio em buscar desvendar as múltiplas e diferenciadas formas de interação e mediação, decorrentes dessa relação. 


\subsection{A CENTRALIDADE DA QUESTÃO AGRÁRIA COMO TÓPICO EMBLEMÁTICO PARA A COMPREENSÃO DA REALIDADE SOCIAL E POLÍTICA}

Ao direcionar a análise para os movimentos sociais do campo, como sujeito político de importância fundamental na perspectiva do ordenamento socioterritorial de Rondônia, já se vislumbra o ponto emblemático da questão agrária como uma questão transversal que vincula outros debates. A transversalidade da questão agrária reflete, portanto, sua dimensão polissêmica, pondo em evidência não só a questão social, como também a questão política. A objetivação dessa questão comparece ora na atuação dos movimentos sociais, ora no papel das organizações patronais, ou ainda nas formas de intervenção/legitimação do Estado.

A questão agrária, como questão social, traz à evidência amplos aspectos das formas de organização da sociedade. No caso brasileiro, essa questão é acompanhada de uma carga semântica enraizada em elementos históricos da nossa economia e nas condicionantes que permeabilizam nossa forma de construção e reprodução do tecido social. Na Amazônia, isso é marcadamente influenciado pelas formas de ocupação/colonização das populações originárias, pelo avanço dos altos investimentos econômicos, subsidiados pelo Estado ou por repasses internacionais, produzindo seus impactantes e danosos efeitos. Em Rondônia, a dimensão social dessas iniciativas levou à constituição de uma sociedade extremamente diversificada, com dificuldades até hoje sentidas em estruturar vínculos, e exposta às vicissitudes do contexto e das conveniências apresentadas.

O tecido social que vai se desenhando no histórico do Estado engloba uma realidade moldada densamente por processos migratórios, com claros sinais de desenraizamento e, ainda, com profundas marcas de contradições culturais, resultado da ação colonizadora. Dessa forma, ao "importar cópias" de modelos e padrões exógenos, em muito reproduziram-se padrões estruturais de desigualdade. Historicamente, blindam-se, pelo esquecimento, muitos dos fatores causais dessa realidade. E isso, com certeza, mantém imune a responsabilidade, histórica e política, pelos danos físicos, culturais 
e econômicos dos povos que aqui viviam, no período precedente aos processos de colonização, a partir da década de 1970.

A questão agrária, como questão política, implica o reconhecimento das contradições e crises estruturais, integrantes do próprio sistema e forma capitalista de reprodução, bem como seus desdobramentos e impactos. Contudo, é importante destacar que essas contradições retratam igualmente outros cenários, como a questão urbana, ambiental, geracional e outras. Como se percebe, são relações entrecruzadas que, mesmo na multilinearidade de suas expressões, envolvem-se e permeabilizam-se de forma transdisciplinar. Do dito, então, ressalta-se que a questão agrária ganha centralidade política, inclusive pela forma como os movimentos sociais do campo se compreendem e atuam, ante o Estado.

Nesse sentido, conforme Delma Pessanha Neves, a questão agrária é dotada de uma multivocalidade, expressa sob os seguintes parâmetros:

Em termos mais consensuais, a questão agrária pode ser entendida como expressão de modos de problematização das formas de expansão do capitalismo no campo. Como ela está diretamente relacionada com o modo de produção geral da sociedade, pode ser entendida como a relação do modo de produção da sociedade com o uso da terra. A maneira como a terra é apropriada está diretamente ligada aos princípios hegemônicos (que não negam os contrastantes) de produção da sociedade. Melhor delimitando, a questão agrária, independentemente da perspectiva analítica adotada, abarca a construção de problemáticas decorrentes das historicamente datadas relações de produção no campo, mais especificamente, das formas de expansão do capitalismo nas relações agropecuárias (Neves, 2017, p. 82).

No cenário brasileiro, a questão agrária tem sido redimensionada historicamente por meio de estratégias de concentração e expropriação do campesinato. Correlaciona-se a isso o impacto que essas estratégias cometem em relação à destruição do patrimônio natural, sob a lógica da "mercantilização da natureza”, ou seja, nas distintas formas de inserção dos bens e recursos à lógica e retórica do mercado. No campo desses impactos, ainda, 
ao incorporar todo o seu "aparato técnico", esse empreendimento não apenas vincula a inserção de outro tipo de insumos na produção de bens, como de serviços. Assim, redefinem, de forma circunstancial, a vida ou as condições de existência e de sentido dos "agricultores familiares", nas diferentes formas de integração capitalista, bem como das populações tradicionais. Quer-se dizer que são impostas, na conveniência do contexto, outras formas de condições de vida e de autopercepção, sob o mote dessas formas dirigidas de integração.

Visto de fora, o impacto desse modelo não é facilmente perceptível, mas efetiva uma transformação profunda, nos modos de produzir, sentir, criar e viver desses grupos e comunidades. Em regra, tais grupos fundamentam seus "modos de vida", ambientando-se numa perspectiva que tem como referência a preservação de costumes. Trata-se de um atributo social essencial, construído, de forma imemorial, em torno da posse coletiva da terra, dos "usos em comum" e da convivência e coexistência integral com o meio. Constata-se, pois, que o impacto produzido simboliza o "choque de dois mundos", um deles infeliz e fatalmente condenado à integração pela via da expropriação. Esse debate ainda sinaliza para o histórico debate entre posse e propriedade no Brasil.

A dimensão de centralidade da questão agrária remonta toda a questão da luta política por reconhecimento de direitos e, por isso, configura-se como uma luta política. Esses sujeitos coletivos viram-se no contexto da elaboração da Constituição de 1988, incorporados ao debate político, não só quanto à questão agrária, mas em uma infinidade de formas de luta na consolidação da cidadania, objetivada e sistematizada, em grande parte, no arcabouço normativo do próprio texto constitucional. Dessa forma, matizadas pelo jogo de forças que representou bem aquele momento, um amplo anseio popular, materializado em múltiplas formas de organização, fizeram emergir para dentro do debate questões secularmente mantidas encobertas: direitos indígenas, quilombolas, relações de gênero, reforma agrária etc.

Graças a estas formas de intervenção que, no tempo e no contexto, diversificaram as formas de atuação, esses novos sujeitos coletivos vão se 
reconhecendo na defesa organizada dos bens da natureza, assim como do controle dos recursos públicos. Passam a adotar diversas estratégias de atuação e enfrentamento: maior participação nas elaborações legislativas, participação em instâncias de controle social, qualificação de agentes e mobilizadores etc.

Outro elemento que desvela a centralidade da questão agrária no atual debate são as diferentes formas de luta, que se encontram e se confrontam nesse cenário específico. Destaque, aqui, para a intervenção de agentes econômicos e financeiros, tanto em âmbito nacional quanto internacional. A apropriação das terras torna-se um instrumental politicamente estratégico para essas forças. Mas importa destacar também a diversidade de segmentos, grupos e organizações sociais, em diferentes frentes de enfrentamento, não só no plano econômico, mas também político e ideológico, contrahegemônicos, para além das fronteiras institucionais clássicas.

Por isso, é preciso agregar outros agentes nessa arena de debates, que incorpora pesquisadores, organizações, jornalistas, setores da Igreja católica, para dar visibilidade social e política de outros campos de conhecimento e de ação. A intuição da presente pesquisa, nesse sentido, busca enfocar, no contexto desse campo de enfrentamento, no Estado de Rondônia, a perspectiva de diversos movimentos que, através de ações práticas, promovem o enfrentamento e o combate das ações do agronegócio, da especulação imobiliária e da grilagem de terras públicas. São esses movimentos - como novas formas de luta - que garantem a objetividade de um conjunto de práticas que vão, desde a luta pelo acesso à terra, incluindo, inclusive, o debate sobre a adoção de práticas agroecológicas e feiras livres, por exemplo. Além disso, a prática de tais movimentos perpassa pela formação política de agentes, consciência e fortalecimento das políticas de gênero, assim como pelo estímulo ao protagonismo das mulheres.

No plano institucional, a questão agrária, como já mencionado neste texto, ganhou importante impulso nos processos de debate da Constituição de 1988 e, posteriormente, na mobilização pela efetivação das políticas lá definidas. Merece destaque, nesse sentido, a perspectiva política em torno da ideia de "agricultura familiar" que, aos poucos, impulsionada 
sobretudo pelo movimento sindical, foi se fortalecendo, inclusive forjando a elaboração de políticas públicas específicas, aplicadas ao setor. Igualmente, no contexto, toda a mobilização voltada para o contexto educacional, objetivada no debate sobre a "educação do campo", principalmente na diferenciação das práticas educacionais, pautadas no contexto do debate em torno da questão agrária.

Um aspecto, dentro do debate sobre a questão agrária, que constantemente comparece, diz respeito à contraposição desse próprio debate. Se, no contexto, foi possível perceber uma "mobilização social" centralizada na questão, é necessário constatar, igualmente, uma contrarreação ao debate. Nesse sentido, vale registrar que foi justamente no contexto da elaboração do $1^{\circ}$ Plano Nacional de Reforma Agrária - PNRA (1985) e na elaboração constituinte que as forças conservadoras do campo se estruturaram e praticamente interditaram a construção de uma autêntica Política Pública ou republicana de Reforma Agrária (Silva,1987; 1989). As iniciativas vinculadas ao patronato rural que reproduziam, com novas variáveis, a concentração estrutural fundiária intensificaram em igual medida o patrocínio da violência no campo. Usando de duas imagens, o médico e agrarista José Gomes da Silva retratou bem o destino da Reforma agrária no país. No contexto do PNRA, publicou sua obra explicativa do fenômeno: "Caindo por terra" (1987), e no contexto da elaboração constituinte, retratou o fenômeno da interdição de uma política agrária mais consequente como "Buraco negro".

Questão candente, seja no âmbito das reformas reclamadas pela sociedade, seja nas demandas dos movimentos sociais, a problematização da questão agrária chegaria, como chegou à Constituinte, sob a marca de um tensionamento inescapável. A pauta retrógrada, tangida pelo conservadorismo, alienado da realidade, esteve e manteve-se atuante e vigilante, em todos os debates, inclusive como aquele que objetivava conceituar a ideia de propriedade. Dessa forma, ainda com um pé no sistema colonial e outro na pressuposta modernidade, o Brasil não terá a propriedade subordinada à lei, nem sofrerá os efeitos republicanos sobre a ela, como em vários outros países “capitalistas e modernos”. Em terras brasileiras, tal direito será tratado como sempre foi, conjugando uma 
dimensão medievo-colonial com as tangências do liberalismo clássico, sem que o mundo tivesse andado.

Esse setor, aliás, também se articulou como movimento e de forma organizada (UDR). Em amplas articulações, recriaram novas relações capitalistas no campo, tangidas sempre pela apropriação da terra e dos recursos naturais. Para tal, demarcaram um verdadeiro campo de enfrentamento, onde, nas condições criadas, opunham-se, muitas vezes de forma agressiva, aos projetos de sociedade embasados na prática e na vida camponesa ou da agricultura familiar. Claramente tornava-se então visível o choque entre projetos de sociedade. Esse campo de disputa, aliás, transcendeu em muito o contexto físico da terra, penetrando nos espaços institucionais-administrativos, academia etc.

No cenário amazônico, instaurou-se um período de implementação de grandes projetos, que vão desde os empreendimentos da mineração, passando pelas hidrelétricas e chegando à consolidação do agronegócio: soja, cana, pecuária bovina. Como se vê, é à luz da disputa por esses projetos políticos que se propõe o debate atual da questão agrária brasileira. De um lado, se reforça a política de acumulação capitalista e, de outro, é onde se localizam as forças sociais que demandam pela objetivação de bens e benefícios, constitucionalmente assegurados.

A situação do capitalismo, nos países periféricos, plasma seus objetivos operando por meio de contradições. Descumprem-se as promessas retóricas da modernidade, uma vez que efetiva-se o aumento das distâncias sociais, uma desigualdade cada vez mais iníqua, e a manutenção, "a ferro e fogo", das seculares estruturas de dominação e injustiça social. Para Ana Clara Torres Ribeiro (2013, p. 216), o capitalismo demonstra, assim, o seu mais evidente "espelho de feiticeira", ou seja, as belas imagens representadas, sempre resultado de "acordos ocultos e indizíveis intenções", mas, a depender do olhar lançado, reflete sua face cruel, sem máscara, face da violência, do desespero, da anulação do futuro. É nessa contradição, no espelho refletida, que se expressa a experiência da modernidade latinoamericana.

Tanto no campo quanto no meio urbano, tais contradições não se operam sem resistências. Nas últimas décadas, esse fenômeno revela-se um 
tanto quanto diluído em distintas ações insurgentes, seja de forma explosiva, seja numa rotina surda e cotidiana, nas formas de ação organizada ou espontânea. Especificamente no contexto agrário e nas lutas socioterritoriais, diversas são as táticas de sobrevivência e resistência.

Em regra, há uma concepção de mundo, elaborada pelas classes patrimoniais no Brasil, que, associada à dinâmica de reprodução do capitalismo, cultiva uma histórica discriminação social em relação aos camponeses. Têm sido típicas desse modelo, entretanto, não só a discriminação social, como também a discriminação racial, de gênero etc., que impactam diretamente e, por vezes, em grau excessivo a classe camponesa. Em suma, a lógica é a eliminação ou a submissão, nas suas formas de produção "integradas" ao modelo reprodutivo capitalista. Dessa forma, no limite dessa sistêmica relação, o campesinato é desafiado a se construir ou reconstruir social e politicamente, diante de tal lógica.

Contrariando consensos, portanto, parece ser possível demonstrar que a diversidade das formas de organização e resistência camponesas portam, sim, um conteúdo político e, em grande parte, reagindo ou enfrentando a imposição do modo de produção capitalista, um conteúdo cognitivo, epistêmico. Justo nesse enfrentamento, contra a subalternização das imposições homogeinezantes do capitalismo, encontra-se, em grande parte, a especificidade camponesa.

Pode-se inserir, com muito mais propriedade, nesse contexto, as lutas socioterritoriais. A percepção de território, em sentido muito maior que terra, redimensiona o próprio conceito de propriedade. À ideia de pertença conjugam-se os pressupostos da identidade, dos modos de ser, fazer, criar, bem como os modos de viver e conviver. Em graus, ainda que distintos, portanto, a emergência dos direitos e sujeitos territoriais, em marcha por reconhecimento e defesa de seus territórios, guardam similaridade com as lutas camponesas, sobretudo contra a submissão ao modelo capitalista de 
produção, de relação e de vida ${ }^{1}$. As integrações, sugeridas e impostas, pela agricultura de mercado, sob a lógica da integração, nada mais são que, na prática, uma reorganização semântica e simbólica de novas formas e fórmulas de submissão.

Resistência e existência, assim, comungam de um único sentido, como numa dimensão ontológica, superando as barreiras da fragmentação ou desagregação. Na lição de Carlos Walter Porto-Gonçalves (2006), a resistência é mais que enfrentamento, é "R-Existência", mais que uma reação à ação de fora, é algo pre-existente, que afirma a existência, e por isso "R-Existe". Assim, pela ação que denega esta existência, como pela afirmação, reconhecimento e enfrentamento dessa condição identitária negada, ocultada, contra a violência que silencia ${ }^{2}$ e interdita, as lutas camponesas e a luta dos povos tradicionais, em sua diversidade, são lutas anticapitalistas, contra-hegemônicas.

O fato de acrescentar esses elementos, considerados essenciais para as chamadas "Teorias do Reconhecimento", não deve causar estranheza. Em primeiro lugar, reforça-se que o caráter transdisciplinar da presente abordagem permite justamente que se estabeleça, de forma incondicional,

\footnotetext{
${ }^{1}$ Reconhece-se a importância do pensamento de Axel Honneth, sobretudo ao detectar a ideia dos conflitos que nascem das experiências de desrespeito social, das agressões às identidades coletivas e individuais, e que acabam por suscitar uma ação que busque, na contramão, instaurar relações que sejam de reconhecimento mútuo. Para Honneth, é nesse processo de lutas por reconhecimento que se verbaliza e se simboliza uma força moral que impulsiona, enfim, o desenvolvimento social. Alega Honneth, contanto, que a experiência da modernidade e, diríamos, da pós-modernidade, tém possibilitado a emergência de distintos graus de desrespeito, a tal ponto generalizáveis, que a lógica moral desses conflitos sociais acabam evidenciando-se, saltando às vistas. Uma possível resposta deverá, segundo Honneth, considerar que junto às formas de reconhecimento mútuo deverão estar justapostos os valores materiais, uma relação jurídica desenvolvida, que potencialize a geração de condições efetivas de solidariedade (Honneth, 2003). Ressalta-se, portanto, que a luta por reconhecimento, vinculada ao fenômeno dos movimentos sociais do campo, compreende e repercute-se em tal análise.
}

${ }^{2}$ A discussão aqui trazida e sustentada coloca-se sob os parâmetros de importantes discussões que atestam a importância da erupção das falas contra os silêncios impostos. Neste sentido, destaca-se a análise de Patrícia Hill Collins, e a necessidade de novas categorias de análise e reflexão (raça, classe e gênero) que possibilitem "alcançar aquele pedaço de opressor que ainda está implantado em cada um de nós” e fazer emergir autodefinições independentes, de outros lugares de fala. E, também, com a contribuição de Gayatri Chakravorty Spivak, abordando diversas possibilidades de fala desses sujeitos localizados em espaços periféricos. Tal abordagem traz às claras, inclusive, a crítica contra as apropriações das falas oriundas dos setores subalternizados. Para aprofundamento, ver em Collins (2015) e Spivak (2010). 
o diálogo naquilo que indica pertinência e referência às demandas sociais levantadas. Em segundo lugar, pelo fato justamente de "reconhecimento, conflito e identidade", no cenário amazônico, serem elementos-chave contra os reducionismos, sobretudo, da ideia de conflito à mera questão de interesses ou da violência, pura e simples.

Em grande parte, a perspectiva de ação e mobilização dos chamados movimentos socioterritoriais (indígenas, quilombolas, ribeirinhos e comunidades tradicionais) encontra, nas chaves categóricas do reconhecimento, da identidade e dos conflitos, propósitos primordiais no impulso à ação e organização. Inclui-se, portanto, essa ideia de que a luta identitária, territorial, vincula-se à luta agrária e camponesa. A gramática dessas ações coletivas, expressas em distintos e diversos movimentos e segmentos, parte, assim, da suposição de que, inclusive em uma revisão teórica, se supere uma "epistemologia catequética" recentrada em suas próprias convicções, muitas vezes impermeável ao diálogo.

A compreensão desse pressuposto, entretanto, não supõe um encortinamento das contradições existentes no interior do modo de produção capitalista, que, no cotidiano, influencia na práxis social do campesinato, e das próprias lutas territoriais. Essa relação contraditória é extremamente evidenciadora das diferentes formas de opressão e desagregação promovidas pelo setor patrimonialista, na forma de contramovimento, contraorganização dos camponeses. Nem sempre a consciência política dessas práticas é perceptível, o que põe em evidência que as próprias lutas camponesas são dinâmicas, complexas e, em grande parte, mobilizadas e definidas pelos contextos em que se inserem (Carvalho, 2012).

A título de registro, nesse cenário, portanto, observam-se as possibilidades e os limites de se pensar acerca do comportamento de classe do campesinato, ante seu enfrentamento contra a burguesia capitalista ${ }^{3}$. Nessa perspectiva, entende-se que defender alguma postura intermediária

\footnotetext{
${ }^{3}$ Por mais relevante que seja tal debate, entende-se, pelos objetivos que circunstanciam os limites do presente trabalho, não ser este espaço oportunizado para essa digressão. Importante análise sobre o assunto pode ser encontrada em Horácio Martins de Carvalho (2012).
} 
de "integração", como conciliação possível, entre o campesintanto e o modelo capitalista de produção, cumpriria apenas a tarefa de ordenar ou reordenar o caminho de manutenção ou sustentação da subalternização camponesa ao segmento capitalista,no caso,ao agronegócio,como padrão elógica capitalista.

Em proporções distintas, a luta camponesa e a luta territorial são eminentemente lutas políticas. São ações coletivas, em graus distintos, espontâneas ou organizadas, que não se esgotam no formalismo jurídico, tradicionalmente compreendidas como a luta da sociedade civil contra o Estado. São ações coletivas que envolvem a materialização de direitos, condições de dignidade, justiça, ideais coletivos e coletivizados. Transcendem, pois, a esfera institucionalizada, os espaços públicos, historicamente configurados. Como se trata de "anseios legítimos", a ação desses sujeitos coletivos vão construindo espaços e repertórios possíveis, naquilo que sinaliza alguma perspectiva ou aproximação ante o Estado, concretizado em seus agentes públicos, agentes políticos etc.

Tão evidente quanto essa constatação é a análise de que a questão agrária no Brasil, sobretudo na forma como se configura, reveste-se de uma verdadeira negação da república. Talvez o maior, se não um dos maiores fracassos republicanos, encontra no campo a materilização dessa evidência. Isso se torna visível, sobretudo, na não democratização do acesso à terra, sacralizando, desde sempre, um abissal direito de propriedade. Outros indícios desse fracasso está na mínima universalização dos direitos civis à população do campo, bem como a tardia extensão do direito ao voto aos analfabetos, característica marcante de grande parte da massa rural brasileira (Guimarães, 2008, p. 276). Acrescente-se, ainda, nesse mesmo compasso, o sequestro ou a denegação de direitos políticos, sociais, laborais, ambientais, entre outros, cuja tutela estatal manteve-se ou mantém, em muito, desconsiderada a essas coletividades.

Relegada à margem das políticas, a questão agrária, especialmente nas últimas décadas, no plano gorvernamental, segue o caminho do arquivo. A homogeneização de um modelo de produção, centrado no negócio exportador, amplia seu espaço no cenário político, campo onde as grandes tramas para revogar direitos, anular conquistas e abafar demandas se consuma. 
Em regra, na história republicana, não houve um governo capaz de romper com a agenda patrimonialista e os interesses agrários hegemônicos.

$\mathrm{Na}$ base do poder, incluindo nos "governos de esquerda" ruralista sempre significou, em tese e na prática, o poder de veto à reforma agrária. Assim, a questão agrária no Brasil incorpora a cultura política do poder instituído, deixa de ser uma questão pública, ou republicana, corporificada em um segmento nacional privatista, secularmente alojado no aparelho do Estado. Para Juarez Rocha Guimarães, é essa hegemonia que criativamente remodela a questão agrária no Brasil:

Ora, na cultura política assim como no poder, não há espaços vazios, se há descontinuidade, silêncios e impasses, de um lado, é porque há permanência, hipervocalização e transformismo, de outro. Ou, em termos mais direitos, o domino de uma narrativa liberal da modernização explica a informulação de uma narrativa republicana da questão agrária. Sem esta doação de sentido que apenas uma narrativa republicana da questão pode fornecer não se constituem plenamente os sujeitos possíveis da reforma agrária, socialmente diferenciados desde sempre pelos ciclos regionais de nossa formação e pela ausência nacional de uma tradição camponesa, e, mais ainda, não se esclarecem os elos que podem sedimentar uma frente pluriclassista e politicamente plural capaz de formar uma vontade nacional pela reforma agrária. (Guimarães, 2008, p. 274)

\footnotetext{
${ }^{4}$ Há que se ponderar sobre a categorização de "governos de esquerda”. Em regra, capitalismo e governos de esquerda se incompatibilizam, ou seja, em amplo senso, governo de esquerda só se efetivaria por meio de uma revolução. Ressalvam-se, contudo, as especificidades da esquerda brasileira e latino-americana, em que muitas vezes a esquerda ganha as eleições, mas não governa. O que implica constatar que representatividade eleitoral, em uma conjunção de fatores, pode incidir inclusive em uma distorção democrática, ao sabor de uma legitimidade formal-burguesa. Revela, ainda, essa inflexão da esquerda, tocante ao assujeitamento a interesses contrários aos do país, a força das elites conservadoras. Nesse caso, teríamos ou tivemos "governos de esquerda" com políticas de direita, quando, no máximo, ocorreria uma maior sensibilidade às demandas populares. Sobre o tema, Bresser Pereira, 2006).
} 


\subsection{A LOCALIZAÇÃO DO DEBATE: MOVIMENTOS SOCIAIS E QUESTÃO AGRÁRIA EM RONDÔNIA}

Em Rondônia, a especificidade desse debate, necessariamente, reivindica um olhar atento, direcionado aos equívocos dos processos e projetos de colonização (anos 1970), a convulsão social e reestruturação fundiária, à luz das diretrizes da empresa rural (anos 1980), e aos desdobramentos e efeitos sociais e políticos, quanto, então, robustece a luta pela terra em Rondônia (final dos anos 1980 e década de 1990).

Dessa forma, após os dramas transformados em projeto de colonização, na Rodovia Transamazônica (1969-1974), iniciou-se o projeto de colonização dirigida do Estado de Rondônia. ${ }^{5}$ Importante registrar que, no Estado, a colonização privada precedeu a pública. Em tese, os modelos de colonização eram orientados pelas mesmas diretrizes, caracterizando, como resultado, por todos os equívocos governamentais, a exclusão de um grande número de camponeses, ao mesmo tempo que exercia forte incidência da acumulação de terras por interesses privados ou conglomerados empresariais (Aubertin, 1988). Repetiam-se, assim, em Rondônia, na experiência da contrarreforma agrária do regime militar, os erros da ocupação da Transamazônica.

O fenômeno restou agravado por um forte crescimento demográfico (grandes migrações), da década de 1980, acompanhado por fraca capacidade de absorção industrial e um modelo discricionário de repasse de terras públicas. Privilegiou a concessão de grandes latifúndios a empreendimentos empresariais, mais preocupados em reserva imobiliária e extração de madeiras que em colonizar. Assim, a região seria palco de conflitos sociais de toda sorte, sempre resultando em violência física, extermínio e devastação ambiental.

Impulsionados sob forte propaganda, institucional ou privada, os fluxos migratórios miravam o antigo território, intensificado sobretudo a

\footnotetext{
${ }^{5}$ O primeiro Projeto Integrado de Colonização foi o PIC- Ouro Preto, implantado em 19 de junho de 1970, na região de Ouro Preto do Oeste. Esse projeto assentou 5.162 famílias, cada qual em uma área de 100 hectares.
} 
partir de 1974. Assim, Rondônia vinha a se constituir não só como alternativa para os excedentes rurais, mas, também, no imaginário facilmente absorvido e alimentado, como "terra fácil", "terra de oportunidades", o "novo Eldorado amazônico” (Nóbrega, 2016). Nota-se que, desde o princípio, a questão agrária está intimamente correlacionada aos processos de ordenamento social e territorial em Rondônia.

Nesse cenário, molda-se a estrutura institucional, nominada de Projetos de Colonização, transparecendo uma clara opção em abdicar de um Programa de reforma agrária, o que representava, à época (e hoje), um fenômeno de evidência política extremamente perigosa. Mas, também, por meio de diversas formas de resistência, nem sempre organizadas, se processou o enfrentamento dessa política de colonização, desvelando tais equívocos.

O conteúdo político-econômico que envolve, portanto, a questão agrária, no contexto histórico da constituição do Estado de Rondônia, indica a forte influência do Estado, como um dos atores essenciais, no comando de tal processo. Salienta-se que não somente foi o antigo Território, e posteriormente o Estado, palco de fortes tensões sociais, em torno da questão fundiária, como também viu-se estruturar e ordenar seu destino, em torno do projeto econômico que envolvia essa perspectiva. Assim, sem deixar de considerar outros componentes históricos, primordiais, não é possível fazer uma inflexão sobre a questão, como se fosse apenas uma política pública, relegada a "mera questão social".

Posto assim, a questão agrária, no contexto, é extremamente elucidativa. De certa forma externaliza os equívocos, travestidos de planos de governo; por outro lado, expressa também os elementos de ligação que vinculam as estratégias do projeto de colonização, traduzidos no plano presente, em questão social e política ainda não resolvida. É nesse aspecto que algumas análises apontam para a permanência das relações coloniais, de um passado que insiste em permanecer, ao se tratar da questão agrária no Brasil, em especial na Amazônia (Paula, 2016; Souza Filho, 2003; Ballestrin, 2013; Fernande, 2015; Martins, 1994).

Outra perspectiva, trazida ao cenário dessa questão, diz respeito ao papel dos atores, no cenário onde as demandas são visibilizadas e 
enfrentadas. A questão posta é mediada por um amplo campo de debate, onde as controvérsias, os enfrentamentos e a construção de consensos vão definindo distintos e diversos papéis. Trata-se, portanto, da compreensão não só do que está em jogo, mas também dos papéis que esses atores representam e as dinâmicas que são criadas e recriadas. São esses os elementos que compõem um cenário fértil e, por vezes, improvável, no sentido de perceber as possibilidades e as potencialidades desses sujeitos em disputa. Em outros termos, a questão agrária, envolvendo as multifaces dos movimentos sociais, os interesses do patronato rural e o Estado brasileiro, quando enfrentada, põe em cena um conjunto de situações que são, ao mesmo tempo, constitutivas, mas também permeadas de influências, e cujo resultado não pode ser previsivelmente simplificado.

Aqui, sobrepesa a força inerente de camadas marginais da sociedade, especificamente dos camponeses, comunidades tradicionais, povos da floresta, indígenas, ribeirinhos e remanescentes dos quilombos, em dinamizar criativa e estrategicamente as ferramentas de resistência. Ainda que, em contexto atual, diametralmente adverso, a luta desses sujeitos coletivos indica um ponto de evidência do enfrentamento dos modelos históricos e estruturais, em sentido de garantia de direitos e de promoção de dignidade, por mais fortes que sejam os interditos e as repressões.

Nesse sentido, a Amazônia - e especificamente Rondônia - subsiste como um locus simbólico no campo das lutas agrárias e territoriais. Por ter sido palco dos primeiros enfrentamentos aos projetos privados e públicos de colonização, no início dos anos 1980, pela articulação dos seringueiros (Rondônia e Acre), na organização dos "Povos da Floresta”, em 1985, por ser contexto do gérmen da organização dos movimentos sociais, no início da década de 1980 (MST, MCC, LCP, MPA, FETAGRO), pelas lutas pelo acesso à terra, transformadas em assentamento, desde o início dos anos 1980, entre outras tantas lutas, é que esse lugar simbólico de resistência política ganha relevo.

Mas, também, não há como ignorar o quanto, na história recente de Rondônia, as questões pautadas na realidade fundiária, em retratos de morte e violência, puseram em evidência a questão agrária. São retratos 
que, na moldura dos programas de colonização, desnudam as evidências ocultas e o escândalo da violência inerente ao enredo, pondo em cena os efeitos perversos de um projeto excludente. Sem máscaras, essas fotografias reais são o contrassenso das "boas intenções", apresentadas nas intenções institucionais.

O destino exterminado dos índios Kanoê, Akuntsu e do "índio do buraco", retratado nas lentes de Vincent Carelli, em vinte anos de "grilagem autorizada" de terras públicas, somada a toda sorte de violência física, no cone sul de Rondônia (Carelli, 2009), foi um desses retratos. Em outro retrato, a "Década da destruição", Adrian Cowell e Vicente Rios (2010), em um documentário, dividido em onze reportagens, desvelam-se os dramas do Projeto de Colonização: o desastre dos contatos com povos indígenas, a colonização e o desmatamento, a abertura de rodovias, o saque da floresta, mineração e violência contra grupos e lideranças dos "povos da floresta". Acrescente-se ainda, a essas cenas, a repercussão do massacre dos camponeses em Corumbiara, em 1995, considerado e lamentado marco que insere, de novo, a questão agrária no debate nacional, no período pós-redemocratização.

Não sem luta e enfrentamento, portanto, a resistência dos grupos e movimentos sociais do campo, em Rondônia, materializou-se por todo o território, nos diversos sujeitos coletivos, objetivando reconhecimento, terra ou direitos. Esses movimentos socioterritoriais, então, incorporam e articulam, de formas e repertórios distintos, a ação coletiva contra-hegemônica, tanto em relação à violência institucionalizada, quanto à violência privada.

Como se percebe, na idealização dos Projetos de colonização, a lógica do "vazio demográfico" e sobretudo a perspectiva de destino da Amazônia tangeram os empreendimentos governamentais, agenciados financeiramente pelo capital internacional. Essa ideia de "destino manifesto" da Amazônia, a partir da década de 1970, é simbólica e pragmaticamente constituída, mobilizando um grande contingente populacional para a "fronteira desconhecida", que, pela propaganda, se tornou fronteira do progresso e da civilização.

Com o discurso do "novo bandeirantismo", vinculado ao anterior, à época solenizado como "marcha para o oeste", tal empreendimento será 
batizado como Projeto de Integração Nacional. Nesse sentido, as contradições se evidenciam, apontando as ambiguidades do intento colonizador:

O equívoco refletido em tais projetos de colonização revelou-se não somente pelo descompasso entre a propaganda e a realidade que as mithares de famílias do sul e sudoeste do Brasil enfrentaram, mas especialmente pela dizimação de dezenas de povos e comunidades indígenas, inclusive afetados por doenças até então não conhecidas, pela destruição dos seus recursos naturais, pelos inúmeros conflitos suscitados por parte de grileiros, madeireiros e pistoleiros contra as comunidades extrativistas, seringueiros e castanheiros, entre outros (Chagas, 2012, p. 84).

Assim, a expansão dos projetos de colonização atinge Rondônia, e a "terra dos sonhos" torna-se a "terra dos conflitos", substantivado no desencontro histórico, ainda que planejado, sustentado e subsidiado institucionalmente. Percebe, também, que essa nova gramática discursiva dos projetos de colonização, verbalizada ou traduzida, nos discursos, linguagens e imaginário, implicam pressupostos inexoráveis.

Em primeiro lugar, há a perspectiva exógena, pautada pela lógica do desenvolvimentismo, em detrimento da vida e sobrevivência dos ocupantes locais, originários. Em segundo lugar, a incorporação constitutiva da sociedade envolvente e mobilizada, planificada na desigualdade. Quer-se dizer que o projeto de colonização, desigual no pressuposto, desigualou no predicado da formação da sociedade, uma vez que está pautado e tangido pela lógica da exclusão, sobretudo nas formas de acesso à terra. Em terceiro lugar, devido à subserviência consentida, instrumentalizada na legitimação do Estado dirigente, potencializaram-se as condições de reprodução do capital, cartelizando os interesses privados, hoje visualizados, sobretudo, na hegemonia do agronegócio e seus efeitos.

Exemplifica essa dinâmica, inclusive, os interditos ao acesso à terra, promovidos pelo Estado, os limites das formas de reprodução camponesa, e o cerco coercitivo, público e privado, às formas de resistência, objetivado, principalmente, no cenário atual de violência agrária no Estado de Rondônia. Importante destacar que o patrocínio dessa violência se configura, 
em regra, pela "cobiça pelo Norte", perpetrada por um amplo processo de grilagem, abrindo, assim, os caminhos para a apropriação da terra pública pelos “donos da terra" (Asselin, 1982). As ocorrências de chacinas de povos indígenas e de camponeses, em Rondônia, são, indubitavelmente, os frutos colhidos desse perverso processo originado e sustentado pelos programas de colonização. A violência agrária, em Rondônia, é um campo emblemático para a análise política desse contexto.

Uma perspectiva de abordagem dos processos de colonização, enfim, convida também para uma mirada sobre a própria questão do campesinato. A frente de expansão e mesmo as fronteiras agrícolas constituem-se como um campo complexo, onde a presença camponesa é traduzida por diversas formas de percepção. No caso específico de Rondônia, nas mobilizações migratórias, dos anos 1980, duas concepções (ambíguas) predominaram, acerca da compreensão sobre o uso da terra: uma perspectiva, na linha do campesinato tradicional, fundada em valores morais (terra como valor de uso), e uma perspectiva utilitarista, moldada na percepção utilitarista (terra como propriedade econômica).

$\mathrm{Na}$ percepção das origens ou procedência, esse "migrante-colono" foi, em grande parte, "mobilizado" pelos valores de uma ordem econômica, vigente e convincente. Ou proveio de uma situação em que havia sido proletarizado, ou então, incorporou seus "sonhos proprietários" na propaganda da "terra fácil" ou "terra de oportunidades". Na análise de Otávio Guilherme Velho (1972), na frente pioneira ou novas fronteiras, esse sujeito seria o agricultor "recampisenado", fazendo de tudo para não voltar à antiga condição de pobreza ou de cativeiro.

Assim, uma questão que se coloca é se esse "camponês recampesinado" se compreende como força política no processo de colonização. Em caso afirmativo, cabe ainda a pergunta: isso acontece mesmo se sua atuação, circunstanciada pelas motivações que o mobilizam e pela conjuntura em que se percebe, reúne condições e possibilidades de organização, mobilização e resistência, sobretudo quando suas pretensões, alimentadas pelas promessas oficiais e oficiosas não foram atendidas? 
Sob o olhar etnográfico de Klaas Woortmann (1990), em situações de colonização, as comunidades amazônicas são apenas marginalmente ligadas/vinculadas à economia desenvolvimentista e monetária. Ocorreu uma espécie de incorporação precária e, muitas vezes, esses grupos, ainda que mantendo vínculos com a terra, tiveram que se assalariar. A hipótese aqui é a de que, em boa parte, essa realidade de colonização imposta, nas primeiras décadas (1970-1990), forjará ou fomentará, de forma mais articulada e organizada, a luta pelo acesso à terra, posteriormente. Constata-se, pois, que o empreendimento inicial proporcionou ao campesinato, ainda que na condição de "sem-terra", uma inserção no ciclo de desenvolvimento doméstico, não abstraindo, contanto, o sonho maior da conquista da terra, como terra de trabalho (Woortmann, 1990).

A ambiguidade, também retratada pelo autor, expressa a instrumentalização (domesticação) produzida pelo ímpeto colonizador, no imaginário migrante. Essa incorporação, bem trabalhada e imposta pela lógica do desenvolvimentismo, foi facilmente recepcionada pelo campesinato, num primeiro momento. A "recampesinização" na perspectiva da terra de trabalho, atendia, assim, ao mesmo tempo, a um objetivo materializado nas pretensões dos migrantes-colonos e às diretrizes de fundo, dos empreendimentos da colonização dirigida. Em condições de subalternização, esse campesinato, em maior ou menor grau, contribuiu, em muito, para o "amansamento da terra" para os grandes empreendimentos posteriores: abertura de estradas, derrubadas etc.

No campo das relações sociais, a trama da colonização, em maior ou menor grau, também “cuidou” para que a questão da terra não se politizasse. Ou seja, cuidadosamente criaram-se mecanismos que norteassem os padrões de estrutura, não aos moldes das "colônias" do Sudoeste e do Sul do Brasil, onde o sentido de identidade e pertencimento são um componente forte de organização e participação. No contexto da colonização em Rondônia, imprimiram-se medidas que impedissem tal "perigo político".

Ciente da diversidade das origens, muitas vezes os mecanismos de destinação das terras aos migrantes-colonos eram implementados de forma que inviabilizassem as iniciativas de organização. Ainda que não 
oficialmente assumido, temia-se que os laços de procedência, vínculos religiosos, ou outras influências, viessem a potencializar formas organizadas de ação. Entrementes, as próprias condicionantes do projeto, associadas ao intenso fluxo migratório, fez emergir, no meio rural, do Estado de Rondônia, uma realidade de múltiplas configurações sociais, de diferenciadas formas de uso da terra, de produção, e de outros vínculos, culturais e religiosos.

Há que se registrar, contanto, que, em especial na década de 1980, em Rondônia, foi a Igreja católica, organizada em suas dioceses, paróquias e comunidades de base, que alicerçou as primeiras organizações, seja na resistência contra a expropriação, seja na luta direta pelo acesso à terra. Assim, será criada a Comissão Pastoral da Terra em 1979 que, junto com centenas de Comunidades de base e outras Pastorais sociais, desenvolverão, sob a inspiração da Teologia da libertação ${ }^{6}$, uma perspectiva evangélica e emancipadora de participação, organização e mobilização dos camponeses, por terra, direitos e dignidade.

É possível, então, constatar que o migrante-colono experimenta uma forma de inserção marginal ou periférica, nas condicionantes dos projetos de colonização da fronteira agrícola, a partir dos anos 1970. As análises trazidas como suporte (Velho, 1972; Woortmann, 1990 e Murta, 2014) assinalam que, a par das ambiguidades dos processos de colonização, a força propulsora desses empreendimentos indica a hegemonização de uma lógica puramente econômica. A possibilidade, portanto, é que essa espécie de "recampesinização" implica não mais que uma forma de transição para um padrão tipicamente capitalista de agricultura.

\footnotetext{
${ }^{6}$ Acerca da importância da Teologia da Libertação nos processos de motivação, constituição e mobilização em torno dos movimentos sociais do campo, importante ressaltar a contribuição de Enrique Dussel e Leonardo Boff. Em Dussel, as categorias da alteridade, da identidade e ethos latino-americano, a ruptura epistêmica e uma releitura dos elementos de análise de Marx. Tais contribuições alicerçaram o plano da "Filosofia da Libertação" e influenciaram tanto as Comunidades de Base quanto os movimentos sociais rurais, por toda a América Latina. Já a importância de Leonardo Boff repercutiu sobremodo no campo da Teologia da Libertação, a partir da perspectiva de uma leitura sociológica dos acontecimentos, sua correlação com a prática libertadora dos cristãos e o protagonismo dos pequenos e empobrecidos, contra a lógica secular de opressão. Muitas são as obras produzidas e disponibilizadas por tais autores, algumas, inclusive, de fácil acesso.
} 
Objetivamente, não há muito de novo, uma vez que o padrão capitalista pátrio, não de hoje, tem se caracterizado pela cimentação dessa relação entre forças políticas e as forças econômicas. Dessa forma, a conjugação desses interesses colocam o Estado à disposição da efetivação de programas e projetos, em que o político e o econômico se suplementem. No cenário amazônico, resultou muito claro as grandes concessões minerárias ao capital extrativista, nacional e estrangeiro, e a forma discricionária com que se protegeram grandes áreas de terra na colonização da transamazônica etc. No caso de Rondônia, a confluência desses interesses possibilitou o favorecimento às iniciativas de colonização privada, a regularização de grandes áreas, visivelmente griladas, e as desoneradas licitações públicas, favorecendo a transferência de grandes áreas de terras a "empreendedores rurais" do Sul e Sudoeste brasileiro.

Ao propor, portanto, a questão agrária, como tópico emblemático, e Rondônia como locus simbólico, no presente estudo, pretende-se desvelar o objeto e o contexto em que as formas organizacionais e as estruturas de poder se articulam. Ainda que muitas análises já apontam para o descarte da questão agrária como questão política, não há como negar os impactos sentidos e ainda provocados na conformação socioterritorial, política e econômica de determinado território. Em tempos de hegemonização do agronegócio, não há como relegar essa questão aos bastidores dos cenários políticos e econômicos.

Naquilo que configura, no discurso oficial, como uma questão periférica, ou marginal, a questão agrária, posta em questão pelas ações coletivas dos movimentos socioterritoriais, indica o grande esforço em superar um duplo movimento. Primeiro, em afirmar e superar a opacidade imposta à realidade agrária, vista como inferior ou inexistente. A percepção dessa invisibilidade é o que legitima a precariedade de direitos. Contra isso, as insurgências. Em segundo lugar, interligado ao primeiro, o enfrentamento da desconsideração institucional, que historicamente mantém de forma inaudita os reclames de milhões de camponeses, assalariados rurais, agricultores familiares, populações tradicionais. Contra isso, as mobilizações e lutas dos movimentos socioterritoriais. 
No caso em estudo, Rondônia, a análise se faz preponderante, em virtude de ter sido e estar sendo uma região onde, sucessivamente nas últimas décadas, o Estado tem alocado recursos para os grandes projetos. É nessa mesma toada que também o agronegócio tem, recorrentemente, celebrado sua ampliação territorial, seus lucros e suas perspectivas. E não há espaço para dúvidas; na associação conjugada entre poder econômico e poder político, um setor precisa arcar com o ônus, a sociedade. 


\section{ESTADO E QUESTÃO AGRÁRIA: RELEITURAS POLITIICAS E DIÁLOGOS COMPLEMENTARES}

É inconteste a reflexão de que a luta pelo acesso à terra é uma luta eminentemente política. No caso analisado, o processo totalizador da colonização, em suas complexas relações e conexões, revela-se como elemento fundante e instituinte, na compreensão desse contexto. Em síntese, representou a colonização, sobretudo pelo protagonismo do Estado, um instrumento crucial de integração da Amazônia na lógica expansionista do capital.

Por isso, compreender essas imbricações, a um só tempo, remete à compreensão seja do papel do Estado, seja da percepção da centralidade da questão agrária, seja da atuação dos movimentos sociais. Assim, buscar-se-á, de início, promover a interlocução, na forma de diálogos cruzados, entre as ideias de Antonio Gramsci (1891-1937), José Carlos Mariátegui (1894-1930) e Raimundo Faoro (1925-2003), em relação à questão agrária e seus desdobramentos. De forma complementar, levantar-se-ão outras pontuações sobre o mesmo aspecto, buscando alargar o horizonte analítico de compreensão da temática e suas variáveis.

\subsection{ANTONIO GRAMSCI E A QUESTÃO MERIDIONAL}

A “Questão meridional” foi escrita em janeiro de 1926 e, sem a pretensão de adentrar na profundidade da teoria, a ideia é encontrar registros e sinais que ajudem a compreender duas questões fundamentais que se interligam. De um lado, o contexto da organização revolucionária, no quadro geral e, de outro, a possibilidade de um protagonismo nas lutas políticas por parte dos camponeses. Ressalta-se que, na obra, a questão meridional configura a situação agrária e fundiária do sul da Itália e das ilhas correspondentes.

Para os intelectuais comunistas da região de Turim, a questão posta se dava no sentido de perguntar: se, não tendo o campesinato as condições materiais para se autoemancipar, como se daria esse processo? A proposta 
de uma ala de vanguarda revolucionária elaborava a fórmula mágica para resolver o problema agrário: "dividir o latifúndio entre os proletários rurais", sem nenhuma referência aos camponeses. Nesse sentido, para Gramsci, faz-se imperativa a necessidade de uma aliança, sob a direção do proletariado, a fim de que este dirigisse a organização político-econômica camponesa (Gramsci, 1987, p. 137).

Assim, numa primeira impressão, Gramsci enquadra a luta camponesa numa ação revolucionária de classes, sob a direção do proletariado industrial. O mérito inicial, aqui, é justamente colocar a questão agrária em pauta, (des)isolá-la. Para o autor, o que pesa, aqui também, é a influência da cultura (camponesa), com seus anos de tradição, como instrumento fundamental para determinado projeto de sociedade.

Mas, para se chegar a isso, faz-se necessária a superação do senso comum e dos preconceitos na condução "intelectual e moral" do processo revolucionário. No caso da Itália, o preconceito era contra os povos do Sul, sobretudo os camponeses. Isso ganha relevância, porque a hegemonia não se dava apenas no plano político e econômico, mas também no plano moral e cultural. A constatação decorrente e óbvia: para Gramsci, faz-se necessário encontrar ou olhar para as particularidades da formação das regiões italianas, e encontrar nesses processos, no sentimento de revolta, aquilo que germina a revolução, os processos de transformação.

A pedagogia a ser adotada, conforme Gramsci, não diz respeito a um mimetismo de outras experiências, mas, antes, é preciso fazer um profundo estudo das particularidades de cada região, ou seja, superar, para além dos (pré)conceitos, os resíduos corporativos, despojar-se deles (Gramsci, 1987, p. 146). Dessa forma, uma leitura coerente da realidade buscará compreender a formação de determinado grupo social, sua subjetividade, e fazer dessa subjetividade, naquilo que se aproxima, um elemento que aglutine as diferenças. E, assim, poderá criar-se, na Unidade, ou tornar possível, a execução de determinado projeto hegemônico do proletariado, direcionado à revolução que se almeja.

Em sua obra, Gramsci evidencia que, quando a discriminação regional e cultural toma as formas de uma ideologia, é nesse momento que se 
sufoca a diversidade, interditando a possibilidade tanto do diálogo, quanto do consenso. E, naquela década de 1920, na Itália, era o que ocorria na leitura que o Norte fazia do Sul, cujos habitantes eram vistos como semibárbaros, atrasados e como obstáculo para a revolução (Gramsci, 1987, p. 139). No processo revolucionário das prioridades, essas são as primeiras a serem atingidas.

O nascimento do sindicalismo, como uma reação ao bloco da burguesia, não daria conta da articulação e mobilização do "setor do campesinato". Na essência, isso ocorrerá porque as motivações desse sindicalismo, por sua condução intelectual, e por sua essência ideológica liberal, tenderá para o nacionalismo, na retórica e na pragmática liberalista (Gramsci, 1987, p. 148-149).

Nesse compasso, Gramsci analisa o papel do intelectual que, segundo ele, é o elo entre o camponês meridional e o grande proprietário de terras (Gramsci, 1987, p. 157). Lembra, contanto, que em todos os países o estrato dos intelectuais foi radicalmente modificado pelo desenvolvimento do capitalismo. Alerta Gramsci, contudo, que a presença e a influência do intelectual, como elemento organizativo, tem forte relevância. E, assim, na Itália meridional (considerada uma sociedade atrasada e desagregada), o intelectual na sua face camponesa é democrático, na face voltada para o grande proprietário é reacionário e, perante o governo, é politiqueiro, corrupto e desleal (Gramsci, 1987, p. 155).

Nessa digressão feita por Gramsci, a perspectiva é compreender o papel do intelectual também pela sua origem que, para ele, na região meridional da Itália, deriva de uma camada notável, ou seja, da burguesia rural. Assim, não é camponês, não trabalha na terra, mas cede a terra (aluguel ou meação), para extrair disso renda, para pagar o estudo de seus filhos. Dessa dinâmica, constata-se uma cultura de aversão ao campesinato (Gramsci, 1987, p. 157).

Quanto à forma de organização dos grandes proprietários, há de destacar, na Itália meridional, a composição de um gigantesco bloco agrário que, no conjunto, não passa de intermediário e guardião do capitalismo do Norte. Mas também está vinculado aos grandes bancos, com o único 
objetivo de conservar a ordem estabelecida. Via de regra, pouca gente, ou organizações, trataram da questão meridional como um problema nacional. Em parte, considera-se que a desagregação da região meridional é também cultural e, assim, quando setores interferem no sentido de fazer que determinados problemas (regionais) não ultrapassem certos limites, a questão não se torna revolucionária (Gramsci, 1987, p. 162).

Adicione-se a isso a influência da estrutura religiosa que, limitada em analisar e compreender a realidade, inflexiona a questão. De tal forma, tende a inviabilizar projetos de mudança, não se desconsiderando que as próprias percepções de mundo estabelecem vínculos, que, em maior ou menor grau, conectam interesses. (Gramsci, 1987, p.162).

Com tais efeitos, as questões postas - na qualidade de elementos de conjuntura, que retratam cenários de desagregação regional e cultural, competitividade de interesses, limites e influência da religião - deslocam, em muito, a questão do campesinato meridional para os setores urbanos, sobretudo o proletariado. Se, por um lado, mapeiam os limites, por outro, demandam pela formação de uma aliança entre o proletariado e as massas camponesas da região meridional, como tarefa revolucionária. Essa tarefa implica, para além de fomentar formas autônomas e independentes entre os camponeses pobres, também a tarefa de desarmar e desagregar a massa intelectual, que blinda e resiste aos pressupostos do bloco agrário hegemônico (Gramsci, 1987, p. 165). De qualquer forma, a aliança do proletariado com os camponeses é aliança inexorável para a transformação, é essa aliança que representa a "porta do futuro".

$\mathrm{Na}$ "Questão meridional”, Gramsci, com sua abordagem de investigação próxima da realidade, percebe as contradições regionais que ocorrem nas condições da classe camponesa do Sul. No entanto, para além das respostas prontas, que sempre identificam causas, efeitos e culpados, entende que tais contradições são social e desigualmente construídas ao longo da história regional. Dessa forma, a própria organização política de classe reflete as relações específicas de um estrato social, que se comporta como massa amorfa e desagregada. Na maior parte das vezes, não se reconhece como classe, no espectro político. A origem desse problema e de suas 
multifaces está na lógica do capital, que assim faz porque lhe é inerente. A desigualdade e a injustiça social são a condição de possibilidade fundamental dessa lógica capitalista.

Nessa dinâmica, o Estado cumpre um papel, mais pela inação que pelos seus projetos e programas de ação. Assim, isso se traduz na falta de investimento do Estado, na ausência de um projeto nacional e nas questões de protecionismo seletivo. Por isso que, na "Questão Meridional”, a proposta de Gramsci é buscar sintonizar os anseios, os discursos e os interesses das classes operárias e camponesas. O que ocorrera é que, a lógica capitalista, fundada na exploração camponesa e na concentração fundiária, amplificou uma cultura do individualismo, que deverá ser mudada, juntamente com as condições de vida do camponês.

Para superar isso, que chama de "desvios de direita", Gramsci propõe a saída projetada nas formas coletivas de produção e com gestão coletiva, pela organização dos operários agrícolas (Gramsci, 1987, p. 123, 137).

No mesmo compasso, uma das principais transmutações na mentalidade camponesa, operada pela burguesia, foi a insistência e persistência na construção de uma mentalidade, segundo a qual o camponês continuava se imaginando como "servo da gleba" (Gramsci, 1987, p. 70). Nesse caso, atribuía-se ao operário industrial, representado pelo Partido, a missão de organizar e politizar o camponês. Esse equívoco conduziu a um fracasso pedagógico, deixando o caminho aberto para o aliciamento político da pequena burguesia (Gramsci, 1987, p. 91).

Configura-se assim tão sedimentada essa ordem que, para as forças conservadoras, abrigadas no Estado e na sua forma capitalista de se organizar, não bastava apenas o controle territorial ou geográfico. Igualmente deveriam promover os instrumentos de organização e direção do campo (Gramsci, 1987, p. 49). E, dessa forma, por meio do capitalismo de Estado, seja no estímulo aos grandes estabelecimentos monopolistas, seja no papel dos gastos públicos na agricultura, seja nas obras de infraestrutura, seria pelo poder burocrático que as forças dominantes manteriam sua união e articulação (Gramsci, 1987, p. 54). 
Por certo, sem haver traumas na ordem, a grande propriedade agrária seria mantida de fora, uma vez que o Estado moderno respeitou, programaticamente, sua essência feudal. Para tal, criaram-se artificialmente as fórmulas jurídicas, como a do fideicomisso, que mantinham intactas as investiduras e todos os privilégios feudais (Gramsci, 69-70). Resta claro, para Gramsci, que o Estado, então, não se resume a instituições de ordem administrativa. A governança, de fato, real e pragmática, fixaria no controle dos meios que permitissem uma transformação material do mundo (Gramsci, 1987, p. 92).

Para além do Estado, Gramsci não deixou de observar, também, a dinâmica organizacional dos movimentos revolucionários. Se tais movimentos não conseguem se constituir como organizações de massas autônomas, com uma percepção plural e diversificada dos processos, pelos quais passa o movimento, terminarão se reduzindo a articulações do aparato estatal. Esse é o caminho mais curto para as composições partidárias que, em tese, são controladas seja pelos intelectuais, seja pelos grandes proprietários ou por seus homens de confiança (Gramsci, 1987, p. 157).

Uma coisa, enfim, resta clara: para Gramsci, os contextos possuem uma força condicionante, capaz de determinar ou redirecionar as estratégias da ação coletiva revolucionária. Em relação às desigualdades regionais, na Itália, no início do século, elas não se estabeleciam somente pelo fato de o Norte ser urbano e industrial, e o Sul, rural, com forte concentração fundiária e intensa exploração camponesa. É nas raízes dessa estrutura que se precisa buscar a forma conservadora como se processou a unidade da Itália, processo chamado de "revolução passiva", que levou a produzir, de fato, as duas "itálias". Não que elas estivessem separadas, visto que são as relações estabelecidas entre o setor da elite industrial no Norte e a latifundiária no Sul que garantiu, em grande parte, a sobrevivência desse modelo (Gramsci, 1987). ${ }^{1}$

\footnotetext{
${ }^{1}$ A ideia de "revolução passiva" designa uma alegoria utilizada na nota à edição brasileira (1987), quando busca os elementos de aproximação entre as questões levantadas por Gramsci, sobre a formação socioeconômica e política da Itália, à época, e a comparação com o Brasil, incorporando ainda a lógica do "transformismo", como elemento de grande utilidade para compreensão dos processos de transição ocorridos na história brasileira.
} 
Dessa forma, é em termos de desigualdade, como instrumento incorporado às formas de desenvolvimento capitalista, que Gramsci vai buscar abordar o problema meridional. Mais que em termos reformistas, essa postura ou abordagem indica uma análise em termos revolucionários, que consigna os elementos de classe, de cultura, de organização desigual da sociedade sob o molde capitalista.

\subsection{JOSÉ CARLOS MARIÁTEGUI E A “QUESTÃO PERUANA”}

A questão agrária é posta em evidência na principal obra de José Carlos Mariátegui (7 Ensayos de Interpretación de la Realidad Peruana, 1928), sobretudo pela análise clara, com que argumenta. Adota, para tanto, os pressupostos do materialismo histórico-dialético, a fim de desvendar uma das condições estruturais da dependência e periferização da nossa realidade. Em primeiro plano, Mariátegui constata que, na realidade peruana, mais que um capitalismo de classe, reproduz-se uma situação de feudalis$\mathrm{mo}^{2}$, onde a velha classe feudal se disfarça de burguesia republicana. Assim, conservou suas posições, sobretudo pela manutenção do regime da grande propriedade. Essa dinâmica possessiva foi reforçada ou engrandecida, depois, pelo liberalismo teórico que, mesmo republicano, agia como intermediário, subalterno do capital estrangeiro e do imperialismo (Mariategui, 2010, p. 44).

Vai se tornando claro, para Mariátegui, que a questão agrária é uma questão estrutural que, uma vez não resolvida, bloqueia qualquer possibilidade de uma verdadeira emancipação:

O Regime de propriedade da terra determina o regime político e administrativo de toda nação. O problema agrário - que até agora a república não pôde resolver - domina todos os problemas de nossa nação.

\footnotetext{
${ }^{2}$ Para Mariátegui, a base de organização feudal ou semifeudal consistia basicamente na adoção e exploração de trabalho escravo, na lógica da agricultura prioritariamente produzida para a exportação, no Latifúndio, enquanto um poder paralelo ao Estado, mas com fortes vínculos de coexistência. Em relação ao trabalho livre, praticamente não há acesso, o que fomenta o trabalho baseado em relações obrigacionais e pessoais, sob péssimas condições de parceria, assim como a sujeição por meio da dívida (Mariátegui, 2010, p. 100-101).
} 
Sobre uma economia semi-feudal, não podem prosperar nem funcionar instituições democráticas e liberais. (Mariátegui, 2010, p.70).

A realidade peruana, tomada no específico, espelha a realidade latino-americana no conjunto. Dessa forma, os processos históricos vividos pelos países latinos, em grande parte retratam as "perdas de oportunidade", uma vez que, em muitos momentos, essas oportunidades de profundas e estruturais transformações estiveram presentes, mas não foram adotadas. Tome-se como exemplo os processos de independência, quando foram beneficiados apenas as antigas classes proprietárias agrárias. Da mesma forma, nos processos republicano-burgueses, a mudança processou-se pelo alto, passivamente, sem grandes transformações na ordem das estruturas.

Para Mariátegui, um pressuposto essencial deverá ser tomado, como reflexão, acerca das possibilidades revolucionárias no Peru, sendo que, em grandes termos, repassa-se a ideia de que a unidade nacional é um obstáculo da luta popular. Assim, a divisão geográfica, “costa, serra e selva”, não era, para Mariátegui, apenas uma divisão física. Em termos simplificados, a selva seria a região do domínio colonial, a costa, região espanhola e mestiça, e a serra, indígena (Mariátegui, 2010, p. 199-201).

$\mathrm{Na}$ serra, predomina o comunismo indígena ${ }^{3}$, sem propriedade privada. No entanto, a marca fundiária do Peru generalizava a cultura do latifúndio e o predomínio do feudalismo. Assim, na análise do autor, além das três configurações geográficas distintas, caracteriza-se, naquele momento, três modos distintos, em relação ao modo de produção e de vida, que influencia diretamente nas dimensões da vida cultural e política desse povo.

Como resultado do modelo de colonização, tanto a vida política quanto a cultura e a economia dos povos peruanos sofrerão os impactos do

\footnotetext{
${ }^{3}$ Mariátegui faz referência, na própria obra, ao comunismo indígena, comunismo incaico ou chamado também de comunismo agrário. Trata-se do modelo, adotado pelos Incas, da propriedade coletiva da terra cultivável pelos ayllus (comunidades familiares). Ainda que dividida em lotes individuais, esta terra era intransferível. Havia também, segundo Mariátegui, a propriedade coletiva das águas, das terras de pasto e das florestas (bosques), demarcadas às tribos ou federação de ayllus. Compunha também a ideia de comunismo agrário ou indígena as formas de cooperação no trabalho e a apropriação individual dos frutos (Mariátegui, 2010, p. 54).
} 
projeto, sobretudo nos conflitos derivantes dessa lógica latifundiária e feudalista. Esse fenômeno de violência institucionalizada e tolerada vai impactar na vida de seus povos, sob diversas formas de violência. Uma das teses principais de Mariátegui, portanto, é reconhecer que a questão da unidade, mesmo admitindo a pluralidade das tradições locais ou regionais, não é o grande problema. A questão central, contanto, é o problema da dualidade de raça, de língua e de sentimento, nascidas desde a invasão e a conquista, por parte de uma raça estrangeira (Mariátegui, 2010, p. 201).

Dessa forma, a mais importante e desafiadora saída é a superação do feudalismo, fundamentado no regionalismo, que se reconhece originário em sentimentos e interesses feudais. Junto a essa tarefa, fundamental, igualmente, é a superação da opressão imposta sobre os povos indígenas. Assim, a condição de possibilidade que cimenta essa face feudal da desigualdade regional é centralizada no latifúndio. Para Mariátegui, a opressão fundamental que garante vida a essa lógica feudal e latifundiária retrata-se no sistema de poder do gamonalismo ${ }^{4}$, que precisa ser extirpado (Mariátegui, 2010, p. 208). Nesse sistema, incorporam-se todas as formas de usurpação material e cultural, alteração de formas de vida e vivências, e sobretudo a violência. Tudo isso com o claro objetivo - travestido de legalidade - de imposição religiosa e expansão do latifúndio.

$\mathrm{Na}$ concepção programática e revolucionária de Mariátegui, a questão agrária, antes de ser regional, é uma questão nacional. Negase, assim, o regionalismo como forma de luta política, em busca de uma unidade de classe.

Uma das originalidades do pensamento de Mariátegui é sua atenção à questão indígena. Em muitos programas revolucionários ou socialistas da época, os povos indígenas não estavam inseridos. A ideia de Mariátegui é buscar propor um marxismo ou uma teoria da revolução,

\footnotetext{
${ }^{4}$ Gamonal, ou o sistema de gamonialismo, foi criado no Peru, pela metade do século XIX, e consistia em uma forma de organização de poder local, onde se configurava uma ordem social em que os proprietários urbanos expandiam suas terras e seu poder sociopolítico por sobre as terras indígenas, instituindo formas coloniais de expropriação e apropriação de terras, nos sistemas de arrendamento, e utilizando-se de meios violentos e ilegais para tal objetivo. Moviam-se, também, pelo estabelecimento de relações de clientelismo, no ímpeto de atingir seus objetivos.
} 
antes de tudo, calcada nas características histórico-culturais de seu país. Por isso, a percepção do indígena como sujeito histórico ativo nas dinâmicas de enfrentamento contra as formas de dominação, sobretudo da classe terratenente. Sob esse signo colonial, o problema da terra alijou-se nos três pilares da herança colonial: o gamonalismo, o latifúndio e a escravidão (Mariátegui, 2010, p. 41).

Como é claro que o regime da propriedade da terra determina o regime político de toda uma nação, em uma economia semifeudal, assim assentada, não pode prosperar nem funcionar instituições democráticas, muito menos liberais (Mariátegui, 2010, p. 42). A galvanização desse processo de saque e destruição opera-se, enfim, quando o feudalismo-capitalismo destrói não só a economia, mas também a cultura, as formas de vida autóctones, sem oferecer, em substituição, alguma forma superior de vida e de desenvolvimento (Mariátegui, 2010, p. 43).

Pelo lado da reflexão sobre o protagonismo indígena, ainda que para muitas correntes clássicas esse fato da inclusão do "não-operário" representasse um desafio e uma desconfiança, isso não ocorreu com a teoria política de Mariátegui. Margeando as ideologias "humanitárias" e mesmo "assistencialistas", muito em voga, no sentido social da incorporação capitalista do indígena, a proposta de Mariátegui, para a solução do drama dos povos originários, se processará através da luta revolucionária. E a primeira dessas lutas será contra o estrato do feudalismo e depois contra o capitalismo (Mariátegui, p. 81-82).

Ainda sobre essa análise, uma conclusão restava clara para Mariátegui: não seria possível qualquer projeto de transformação ou revolução, sem extirpar a opressão sobre os indígenas. $O$ inédito nessa ideia é justamente esse ponto de partida, ao incorporar os indígenas como sujeitos coletivos, até então invisibilizados ou não considerados pelos europeus. Onde muitos revisionistas enxergavam obstáculos, Mariátegui avista possibilidade. Nesse sentido, afirma que a geração peruana sente e sabe que o progresso do Peru será uma ficção, ou seja, não será um progresso peruano, enquanto não seja obra e não se traduza em bem-estar da massa 
peruana, sendo que de cada cinco peruanos, quatro são indígenas e camponeses (Mariátegui, 2010, p. 37, 64).

\subsection{RAYMUNDO FAORO E OS “DONOS DO PODER”}

Iniciemos com Raymundo Faoro, para compreender as principais chaves de leitura que ajudam a analisar a questão fundiária, em suas permanências, no contexto socioeconômico e político. Assim, por consequência, torna-se possível perceber em que incidem tais elementos, na compreensão acerca dos limites e possibilidades de atuação e participação dos movimentos sociais do campo.

Há, segundo Faoro, uma transitividade na questão agrária que cruza a história política brasileira. Em regra, o caminho da legitimidade ou sustentação da ordem proprietária, como causa e resultado de poder, sempre encontrou nas formas legislativas seu arcabouço. Quando essa ordem normativa descumpria o seu papel, o ajuste se fazia pela repressão, sempre atenta, do Estado. Esse indicativo aponta para um repertório de arranjos, sempre funcionais, que na forma de "influências recíprocas" ditavam o caminho da manutenção da ordem. Assim, se houvesse discordância em aspectos periféricos, não poderia haver divergência na ordem estrutural, que significava, na forma e no conteúdo, a manutenção vinculante das grandes propriedades com o Estado central. Dessa forma, os donos do poder se mantinham.

Um dos elementos de fechamento deste status era o regime escravocrata. Para Faoro, então, o mundo rural fecha-se em torno da matéria, interditando também a mobilidade interna e vertical, uma vez que a escravidão, ou ter escravos, significa recursos e créditos (Faoro, 2012, p. 200). Com razão, Caio Prado Junior (2000) vai dizer que, na verdade, a célula fundamental da economia agrária brasileira tem no trabalho escravo seu elemento essencial. E não só, vai dizer também que o DNA que compõe e recompõe a sociedade brasileira é a lógica inscrita no seu passado escravocrata e na grande propriedade (Prado Junior, 2000, p. 121).

Sem traumas, portanto, ocorre, quando preciso, uma simbiose agrário-liberal, para que se proclame a República sem alterar em nada a 
estrutura agrário-feudal. Dessa forma, e sob novas vestimentas, o agrarismo republicano se trasveste, sobretudo na configuração do coronelismo que, como diz Faoro, representa um verdadeiro casamento, onde o regime de bens e relações pessoais será, posteriormente, "acertado" com as oligarquias estaduais (Faoro, 2012, p. 541).

Dessa forma, vai se consolidando a estrutura do patronato político, que não cuida somente de empregos e cargos, mas também "enriquece e empobrece seus protegidos e adversários" (Faoro, 2012, p. 388). Arranjos assim forjaram a Lei de 1850 (lei de terras), quando o latifúndio expansionista investiu contra o regime de posses. Frustrando a possibilidade de uma redistribuição de terras e ressalvando a grande propriedade, pode-se então torná-la terra de mercado, transmissível e avaliável (Faoro, 2012, p. 363).

Em relação ao estamento, Faoro a ele se refere como uma camada político-social, moldada pela solidariedade de interesses, inserida na burocracia do Estado e movida pelo espírito de cruzada, rapina e pirataria (Faoro, 2012, p. 66). Na sua forma, se apresenta esquivo, ou melhor dizendo, não se apresenta, pela sua natureza encoberta e impessoal. Dessa forma:

Este estamento é filho legítimo do Estado patrimonialista, uma vez que ampara estas atividades que lhe forneceram ou fornecem os ingressos, com os quais alimenta sua nobreza e seu ócio de ostentação, auxilia o sócio de suas empresas, estabilizando a economia, em favor do direito de dirigi-la de forma direta e íntima. O encadeamento das circunstâncias históricas, que parte do patrimonialismo e alcança o estamento, fecha-se sobre si mesmo, com a tutela do comércio de trânsito, fonte do tesouro régio, do patrimônio do rei, fonte das rendas da nova aristocracia, erguida sobre a revolução do Mestre de Avis, engrandecida na pirataria e na guerra que incendeiam os oceanos Índico e Atlântico. (Faoro, 2012, p. 68).

Resulta claro, para o autor, que a criatura a quem chama de estamento tem na "solidariedade de interesses" seu perfil organizativo. Para tal, adota uma doutrina pragmática, para criar em torno dela sua ideologia, como se fosse uma abstração que se corporifica em valores de sustentação do 
próprio patrimonialismo. E, quando preciso for, será verbalizada em convicções ideológicas que sufoquem o aparecimento de um pensamento social novo. $\mathrm{Na}$ forma de arranjo, é nesse território estamental burocrático que se coadunam os interesses da classe comercial, mas também a tradição do Estado patrimonial, alocados oportunamente nos encaixes instrumentais do estamento. Firma-se, assim, o Estado patrimonial do estamento como uma estrutura política, em que os interesses econômicos e do mercado sobreviverão imunes.

A burocracia é entendida aqui não no sentido moderno, de aparelhamento racional, mas como apropriação do cargo, cargo esse carregado de poder próprio e sistematicamente aberto e articulado com o poder de plantão no Estado. Assim, pode o estamento, nesse quadro administrativo, reproduzir as estruturas de mando e domínio, configurando, pois, um governo de minoria (Faoro, 2012, p. 91). Não deixa de ser, assim, uma forma de estratificação social. Nessa forma organizacional, a elite pode estar presente, ou pode apenas delegar. Assim também como o povo, uma vez que, na forma orgânica do estamento, ele não entra; afinal, quem remove, consolida os cargos de chefia é o grupo de domínio, quanto ao povo, adotar-se-ão estratégias de captação de assentimento popular (Faoro, 2012, P. 94).

Uma das formas prediletas e instrumentais, adotadas pelo estamento, é a "produção da realidade" pela lei. Aqui, já que o "cargo público" uniformiza em tese os procedimentos, e também onde o "princípio da legalidade" se exaustiva, é o lugar do estamento que "unifica" todas as classes. Com se percebe, em grande parte o estamento é o palco, abstrato, mas por onde desfilam os atores principais, onde as vestes legais ou constitucionais são apresentadas para o apreço da assistência. E nesse e desde esse palco, as entranhas e artimanhas do poder se mobilizam, se transmutam, se preciso for, a fim de representar esse outro país-plateia, país real, disperso e amorfo, porém manipulado (Faoro, 2012, 98).

Assim, o estamento burocrático e aristocrático se sustenta e se expande no patronato. É a economia destacando os representados que se entregam à atividade política, no interior do estamento. Portanto, e por sempre, o estamento será sempre fiel ao patrimonialismo. Se assim se processa 
quanto ao patronato rural, não será diferente quanto à burguesia comercial, muito menos quanto ao exército, que será um grupo profissional vigiado pelo estamento. Em suma, quer-se dizer que, desde as origens, o domínio patrimonial constituído pelo estamento é que se apropria das oportunidades econômicas, das concessões, no desfrute dos bens. Estabelece-se, a um só momento, a confusão entre o público e o privado, onde o patrimonialismo pessoal se torna o patrimonialismo estatal, possível assim de harmonizar prováveis conflitos de interesses por uma orientação política (Faoro, 2012, p. 636).

Estabelecem-se igualmente, nesse estamento burocrático, as condições de possibilidade de comando do campo civil (relações econômicas interpessoais, assim a vida das pessoas: nascimento, casamento, sucessões), o campo militar, podendo invadir a esfera econômica política e financeira, e por ela ser editada (Faoro, 2012, p. 638).

Quanto à relação Estamento-Sociedade, Faoro é sarcástico, porém real. Denuncia quanto valem os ideais republicanos, os apelos democráticos, as promessas do progresso:

As duas partes, a sociedade e o estamento, desconhecidas e opostas, convivendo no mesmo país, navegam para portos antípodas: uma espera o taumaturgo, que, quando a demagogia o encarna em algum político, arranca de seus partidários mesmo o que não têm; a outra permanece e dura, no trapézio de seu equilíbrio estável (Faoro, 2012, p. 640).

Quanto à relação entre o estamento e as elites, e nas estratégias adotadas por cada segmento, Faoro destaca as diferenças. Para o comando elitário, funciona a astúcia, a habilidade e a capacidade de manipular, como qualidades psicológicas de ajuste. Nos estamentos, o que prevalece é a decisão de usar a violência, os instrumentos jurídicos, o calculismo, nas intervenções e na direção voltada para a eficiência. $\mathrm{Na}$ tentativa de emergência de qualquer classe, o patrimonialismo busca blindar o poder, apropriá-lo, para que se dilua na elite (Faoro, 2012, p. 642). Justifica-se, assim, que nem 
sempre quem chega ao governo, na forma estamental, alcançou o poder, na forma como ele se estrutura e se instrumentaliza no estamento. Assegurada no estamento, a elite política pode, portanto, ordenar e ter o comando político, numa ordem de conteúdo aristocrático. Historicamente, no Brasil, o estamento burocrático fundamenta a estrutura patrimonial do capitalismo, tornando-o aristocrático, sobretudo nas camadas da nobreza de toga e do título (Faoro, 2012, p. 647).

Para Faoro (2012), nada é tão claro como a constatação de que é do patrimonialismo que brota a ordem estamental (Faoro, 2012, p. 188). O estamento, nessa dinâmica, será o território de uma extensa rede de clientelismo, demandado e disposto, que faz que as formas de domínio do poder patrimonial se acentuem, no tradicionalismo feito cultura, e no institucionalismo das formas burocráticas (Faoro, 2012, p. 633). Transitando, pois, das formas do sistema feudal para as novas formas capitalistas, resta claro que o patrimonialismo vai se amoldando às circunstâncias, fazendo do Estado seu mecanismo primordial de intermediação. Ali, fecunda-se e se reproduz, com suas manipulações financeiras, monopólios, concessões públicas, controle de crédito, padrões de consumo, totalizando-se num complexo de possibilidades que vai da gestão à regulamentação material e formal da economia (Faoro, 2012, p. 636-637)

Assim se constitui o Estado patrimonial de organização do poder: os chamados bens públicos são apropriados por esse grupo mandatário, que governa mediante funcionários como verdadeiras extensões do local de comando. Nesse sistema patrimonial de feitio estamental-burocrático, sempre periférico ao poder patrimonial, o quadro administrativo vai progressivamente se burocratizar, num processo de mudança que simboliza mais para o arranjo que alteração de estrutura (Faoro, 2012, p. 18).

Para o autor analisado, a resposta ao enigma sobre a evolução de um regime feudal para o molde patrimonial explica-se pela resiliência da forma patrimonial em contratar a rigidez das estruturas feudais. Esse cimento cultural feudal, em boa parte da história, obstou o caminho para a modernidade econômica e política (Faoro, 2012 p. 19). O confronto dessas modalidades de um processo de patrimonialismo vai sendo aos poucos incorporado 
pelas inovações do capitalismo liberal perante as regras do feudalismo. Da condição de satélite do soberano, de forma centralizadora, sobretudo em relação à terra, passará à representação das condições tardias do desenvolvimento econômico e político do Brasil.

Quanto aos aspectos relacionados às relações sociais, a forma de Estado patrimonialista e de estamento, como forma de domínio, se projeta de cima para baixo, ou seja, submete-se às regras convencionalmente fixadas por quem governa (elite dirigente). Reproduzido em escala ampliada, nos Estados, Territórios e Regiões provinciais, semeiam-se aqui, as bases do patronato local, do clientelismo e suas variáveis. Na questão dos cargos de domínio, chefia e gestão, os arranjos são operacionalizados de forma que impeçam revisões desnecessárias, ou que as escalone, quando inevitáveis. (Faoro, 2012, p. 168). Conjuga-se, pois, no patrimonialismo de comando, os instrumentos de controle político da economia: protecionismo, manipulações financeiras intervenções estatais, entre outras (Faoro,2012, 460).

Ao que se constata, na leitura de Faoro (2012), houve uma "resistência e persistência" do patrimonialismo à experiência capitalista. Resistência em razão das transformações evocadas pelo liberalismo capitalista e que "agredia” o status desse patrimonialismo. Persistência, pelo fato de que agradava muito a essa ordem patrimonial os mecanismos de ajuste e manutenção da estrutura social e econômica, fundada em profundas desigualdades sociais.

Assim, quando "manter-se conservador" e reticente às mudanças não se tornou mais possível, adotou-se, à brasileira, a técnica, as máquinas, as empresas, sem, contudo, a necessidade de mudança. Ainda que gerenciada pelo que Faoro detecta como "estamento burocrático", não há como considerar, sem reflexão, que a linha tênue que "separa" esse estamento dos reais interesses do patrimonialismo de Estado é praticamente imperceptível. Quer-se dizer, contudo, que é a elite proprietária, seja ela industrial, agroindustrial, rentista, ou corporativizada, que se aloja no interior do Estado, dando-lhe sentido e impondo-lhe caminhos. 


\subsection{CONTRAPONTO ANALÍTICO 1: PATRIMONIALISMO OU ESCRAVIDÃO?}

$\mathrm{Na}$ busca por entender as correlações entre questão agrária, movimentos sociais e relação com o Estado, já se acentuou o plano da complexidade, nem sempre perceptível a olho nu. No entanto, em qualquer sociedade, busca-se apoio nas ideias, a fim de interpretar o Brasil ou a realidade brasileira. Nas seções anteriores, amparou-se, em grandes linhas, na perspectiva de pensar seja a questão agrária, seja a atuação de sujeitos históricos, seja a organização ou estruturação do Estado. No entanto, o campo das ideias é, e deve ser, campo de debate. A compreensão de uma realidade, de um País, permeabiliza-se por tal debate.

No Brasil, na forma de consenso compartilhado, grande parte da intelectualidade brasileira tem buscado interpretar o Brasil por meio desses grandes autores-geradores, numa espécie de naturalização interpretativa da realidade brasileira: Gilberto Freire, Sérgio Buarque de Holanda e Raymundo Faoro, entre tantos. Trata-se de planos analíticos que, de certa forma, descrevem como a sociedade se organiza, que prioridades recorrentemente são mantidas, que linhas políticas tendem a tornar hegemônicas etc. Assim, a proposta aqui oferecida, é justamente a de demarcar um contraponto no posicionamento teórico do autor brasileiro analisado anteriormente (Raymundo Faoro), para que se estabeleça uma possibilidade de ampliar o debate, sobretudo sobre um dos pontos cruciais da nossa formação histórica. Dessa forma, ao buscar outra referência de análise, postula-se pelo alargamento do horizonte de debate, trazendo outros elementos que possibilitem interpretar ou compreender a realidade agrária, o Estado e a atuação dos movimentos sociais do campo.

Jessé Souza (2017) estabelece em sua obra um esforço para desconstruir alguns paradigmas de interpretação do Brasil. Assim, dois eixos temáticos são tomados como pressupostos para que se possa fazer um diagnóstico da realidade brasileira. Em primeiro lugar, para o autor, foi a experiência da escravidão, e não a suposição abstrata da herança portuguesa (patrimonialismo), que criou entre nós uma dimensão singular de exclusão perversa, 
como raiz de nossas desigualdades. Um segundo pressuposto é que a eterna demanda por privilégios, de determinada classe, leva a uma sistêmica construção de alianças e preconceitos que, na forma de uma construção sociocultural, esclarece o padrão histórico das hegemonias e do poder no Brasil.

Jessé Souza (2017) busca analisar as dimensões da formação social, econômica e política do Brasil, debatendo principalmente com Sérgio Buarque de Holanda (1936/1995) e Raymundo Faoro (1957). Para o autor, faz-se necessária uma revisão teórica, porque se trata de leituras dominantes, que moldaram não só o pensamento liberal, como a própria intelectualidade da esquerda brasileira, mantendo-se como parâmetro e leitura até os dias de hoje.

A leitura recorrente desses clássicos, diga-se de passagem, é utilizada inclusive por arautos do combate da corrupção, que buscam enxergar de forma exclusiva no Estado as raízes dos problemas brasileiros. Para tanto, faz-se necessária, de forma clara e cada vez mais, uma "limpeza política" no Estado, onde foram semeados e frutificados todos os problemas pátrios.

Grande parte dessa tese baseia-se no "culturalismo racista e liberal", ou seja, busca as explicações dos fenômenos sociais, em especial do patrimonialismo e do estamento, em nossas heranças culturais ibéricas, acima de tudo, com olhar míope, para o que acontecia no interior do Estado, na dinâmica interna da classe proprietária e oligárquica, e na questão da ordem da escravidão, como pressuposto fundamental.

Por essa leitura compartimentada, é no Estado que se aloja o patrimonialismo, camuflando de certa forma o "mandonismo real", na forma como realmente se reproduz. Assim, nesse fundamento, evolui-se o conceito de patrimonialismo, a ideia de clientelismo e de populismo, no contexto brasileiro. Por tal clivagem, ainda dilui-se a oposição entre o público e o privado, assumindo a forma do senso comum, que percebe apenas o Estado como uma configuração de interesses organizados. Em outras palavras, é como se apenas sujeitos privados se opusessem ao Estado, seja na intencionalidade individual, seja na perspectiva do homem cordial, nos arranjos possíveis, gravitando em torno do poder instituído. 
A ação do mercado capitalista, nesse contexto, é competitivo e ocultada. Souza (2017) chega a afirmar que nesse pressuposto, a partir de Faoro, o mercado "é percebido como o verdadeiro céu na terra, prenhe de virtudes democráticas que apenas o Estado não permite florescer”(Souza, 2017, p. 80).

Nesse caminho revisitado, revolve-se a própria concepção de "vira-lata" brasileiro, como uma espécie de legitimação perfeita do protofascismo pátrio. Ajeita-se o sintoma à receita uma vez que, se o brasileiro é malformado de nascença, como fruto de uma herança cultural, é nas mesmas moldagens que o racismo da cor da pele, de antes, fora instrumentalizado. E, assim, ajusta-se tudo à narrativa histórica de longa duração, na linearidade conduzida desde o Estado português, transposto para o Brasil

$\mathrm{Na}$ crítica de Souza (2017), a tese de Faoro faz muito bem a tarefa de vincular o caráter patrimonialista do Estado a toda a sociedade brasileira. $\mathrm{E}$ aqui, então, estariam aprofundadas as condições não democráticas do individualismo baseado em privilégios, que teria, desde sempre, marcado o exercício do poder político no Brasil. É nesse ponto crucial que o patrimonialismo substitui, no lugar e no tempo, a noção de escravidão e das lutas de classes que se formam a partir dela. Facilmente, e sem traumas, a corrupção patrimonial toma lugar da análise das classes sociais e de suas lutas por apropriação de recursos materiais e imateriais em falta.

Dessa forma, como o Brasil herda a forma de exercício de poder político de Portugal, vemos a herança ibérica fundando suas raízes em nossa sociedade, e achamos, assim, o responsável pela nossa forma de relação com o capitalismo "para inglês ver", ou a modernização capitalista, pretendida pelos ingleses.

A ação demonizada do Estado, agora apropriado, valida a tese política da contraposição do Estado ao virtuoso mercado. Essa é a ideia-força fundamental para o liberalismo brasileiro. Por essa razão, nas poucas vezes em que se acentuou alguma preocupação política com as reivindicações das classes populares, o ponto de partida era e sempre foi o Estado. Opera-se, desse modo, um deslocamento da questão de sua substantiva desigualdade, dos conflitos, tácitos ou expressos. Essa linha de cognição e interpretação 
da sociedade brasileira é nossa peculiaridade, e estabelece-se em nome do pseudo-conflito entre mercado (virtuoso) e Estado (corrupto).

A noção de público/privado, na verdade, não se aplica, uma vez que essa noção é bem posterior, do ponto de vista histórico. A lógica de privatização do "público", tomada de assalto, é feita por agentes que estão fora dele, principalmente na dinâmica do mercado que controla e "permite" a noção substantiva do que é público. Assim também a ideia de "soberania popular”, que delimita a oposição público-privado, na esfera política; apesar de começar no século XVII, só se materializa ainda mais tarde.

Portanto, o patrimonialismo, como apropriação (privatismo) do público, para Souza (2017), é uma ideia a-histórica, portanto, fora do contexto. Dessa forma, a dinâmica que impõe o mercado sobre o Estado, como liberalismo de mercado, carece de incluir o poder de controle do mercado, na condição de base do capitalismo e da democracia.

O cálculo dessa lógica, em termos atuais, levaria indubitavelmente à criminalização da política. Quando a economia dispensa a mediação da política, resulta extremamente conveniente que lá sejam colocados seus arautos, burocratas, indicados, sem voto, muitos, inclusive, vangloriados da própria impopularidade. No entanto, são eficientes, uma vez que representam a garantia cega à elite econômica, em seu processo de rapina e saque, seja dos bens públicos, seja do povo, como um todo (Souza, 2017, p. 128).

De tal forma, para Souza (2017), o Brasil não tem como herança de Portugal sua estrutura social, mas essa estrutura se baseia no regime sistêmico da escravidão, que não existia em Portugal. E, em consequência, a regra estruturante do patrimonialismo, fixado no Estado estamental, não se contrapõe ao desenvolvimento capitalista. E, assim, a centralidade desse sistema, quando localizada analiticamente na corrupção como herança portuguesa, invisibiliza as desigualdades sociais instauradas secular e colonialmente no interior da sociedade, assim como as classes estigmatizadas e perseguidas. Por esse prisma, a análise centralizada no discurso moral da corrupção esconde o sistema de dominação nas relações entre as classes sociais, assim como reduz os problemas à mera dimensão econômica, uma retórica palatável inclusive para manutenção sistêmica das desigualdades. 
Em termos modernos, sustenta Souza (2017) que o "patrimonialismo moderno" ${ }^{5}$ não aceita correção de rota no seu itinerário. Qualquer aceno no rumo de respeitar direitos constituídos, de respeitar contratos celebrados, de pautar políticas vinculadas a direitos sociais, é prontamente percebida como um ato em si mesmo expropriatório, sendo, portanto, passível de uma forte e violenta reação contrária. E, assim, a "lógica consentida" de uma narrativa do patrimonialismo estatal esconde a lógica de funcionamento do mercado, restringindo a ideia de elite dominante apenas à esfera estatal. Tal narrativa, para Souza (2017), reflete a hegemonia do liberalismo conservador, que coloniza o pensamento crítico, inclusive da esquerda, no Brasil.

Um registro contemporâneo merece espaço, no entanto. Para o establishment, inerente a essa condição discursiva, a manipulação midiática tem sido essencial, uma vez que manipula a conjuntura política concreta, de forma funcional, permitindo que a elite econômica se dê o luxo da sombra, sem a necessidade de se envolver em disputas políticas. Esconde-se, então, de forma ainda mais sutil, a relação demasiadamente obscura entre economia e política. Ajustadas as roupagens, o patrimonialismo pode assumir inclusive determinadas gramáticas (patrimonialismo social-democrata), pragmática o suficiente para assegurar popularidade e adesão das massas.

Enfim, é fundamental deixar interligada a percepção de uma realidade que se reedita ao sabor das conveniências. A sociedade brasileira, ao não romper com as velhas estruturas, mantém no seu DNA as possibilidades de autorreprodução de tais estruturas, asseguradas por uma legitimidade excludente em essência, e naturalizadas por novos mecanismos de persuasão e de fabricação de consensos. Por isso, conclui Souza:

A história da sociedade brasileira contemporânea não pode ser compreendida sem que analisemos a função da mídia e da imprensa conservadora. É a grande mídia que irá assumir a função dos antigos exércitos de cangaceiros, que é assegurar e aprofundar a dominação da elite dos proprietários sobre o restante da população. A grilagem agora não

\footnotetext{
${ }^{5} \mathrm{O}$ autor, no entanto, entende que o termo "patrimonialismo moderno" é um contrassenso conceitual, amparando-se inclusive na ideia de Max Weber, inventor do conceito, para quem a ideia de "patrimonialismo" é inseparável de precondições que são pré-modernas.
} 
assumirá mais apenas a forma de roubo violento da terra dos posseiros pobres, mas sim também a forma da colonização das consciências com o fito de possibilitar, no entanto, a mesma expropriação pela elite. Substitui-se a violência física, como elemento principal da dominação social, pela violência simbólica, mais sutil, mas não menos cruel (Souza, 2017, p. 119).

\subsection{DIÁLOGOS COMPLEMENTARES: DIMENSÕES NO AGRÁRIO NO CONTEXTO POLÍTICO}

Outras leituras políticas deram conta de analisar a questão agrária e patrimonial e seus efeitos na ordem social, econômica e política brasileira. Isso implica dizer que tal questão, para além da sua centralidade analítica, condensa os efeitos que refletem características marcantes da sociedade brasileira. O pressuposto essencial assenta no destaque de que o problema agrário reflete não só padrões de distribuição de terra, mas também de poder, define ou constrói o espaço social e suas relações, ajustando no conteúdo e na forma a hegemonia do padrão econômico sobre a situação política e, sobretudo, social do país.

Neste sentido, Alberto Passos Guimarães (1981) reconhece o vínculo entre o latifúndio e a monocultura de exportação, sempre em detrimento da produção de gêneros alimentares para o consumo interno. Essa, aliás, é uma condição de existência de características feudais em nossa vida rural, para o autor. Ao estabelecer o monopólio feudal da terra, como uma espécie de condição colonial, atinge não somente as relações de domínio sobre coisas e pessoas. Acentua também o nível de dependência ao mercado e capital internacionais, numa verdadeira relação umbilical. Essas características, presentes em nossa estrutura fundiária, inclusive atual, se efetivam como herança direta do regime colonial, secularmente instituído em nosso país.

Para Caio Prado Júnior (1942), não há dúvida de que um dos fatores principais que resguarda a concentração da propriedade agrária provém de nossa herança colonial, que insiste em se perpetuar, impedindo uma mais equitativa distribuição da propriedade agrária ao lado de uma atividade 
comercial mais dinâmica. Conforme o autor, um dos atributos desse condicional vínculo é a isenção fiscal de que goza a propriedade fundiária, sobretudo a grande propriedade, sob a forma de um autêntico privilégio fiscal. Para Prado Júnior, em resumo, três elementos (grande propriedade, monocultura e escravismo) se conjugam num sistema típico, numa mesma unidade produtora da formação social, da economia agrária e dos fatores de poder.

Com Nelson Werneck Sodré (1962), é possível constatar que a consolidação da classe senhorial no poder reflete, paradoxalmente, um anacronismo que vai evoluindo. Do escravismo evolui para o trabalho livre, para o trabalho assalariado, sem, contudo, desconstituir a natureza e a dimensão latifundiária. Confirma, ainda, que as consequências da escravidão são tão profundas que, na impossibilidade de explicar as causas e os efeitos, busca-se alimentar a consciência do povo, alimentando-a por abstrações. Assim é que se constroem as narrativas da "preguiça brasileira", da "luxúria", do gosto pelo ócio e não pelo negócio, da influência climática como condição anestesiante, e por aí vai.

Na mesma perspectiva, no entanto, a partir de outra abordagem, Josué de Castro (1946) foi incisivo em constatar que a deficiência alimentar que a monocultura impõe se efetiva através da fome que o latifúndio gera. E vai mais longe, ao dizer que, nas origens, ao lado dos fatores de categoria biológica constatáveis, há de se considerar, como essencial, os fatores de natureza cultural. Trata-se, pois, de fatores vinculados ao latifundismo agrário-feudal que tanto deformou o desenvolvimento da sociedade brasileira. Os efeitos são evidenciáveis, uma vez que as pequenas propriedades, voltadas à produção alimentar, são "engolidas" pelo latifúndio. Assim, entre os resultados dessa prática econômica e política, temos o subdesenvolvimento, que nada mais é que a expressão da monocultura, do latifúndio e do feudalismo agrário.

Já Victor Leal Nunes (1947) buscou dar evidência à intrínseca relação existente entre a arquitetura proprietária e as relações de poder e domínio, em âmbitos também locais ou regionais. Há no Brasil um sistema que descreve um compromisso, uma espécie de troca de favores e proveitos entre o poder público e a decadente influência socialmente construída dos chefes locais, especialmente os "senhores de terras". A compreensão de tal fenômeno não 
se fundamenta sem a referência à nossa estrutura fundiária. Pela lógica dessa estrutura, assimétrica nas origens, encontram-se as bases do poder privado, às expensas conhecido no Brasil. Paradoxalmente, entretanto, esses remanescentes do privatismo são retroalimentados pelo Poder público. Como isso se dá? Justamente em função do regime representativo e do sufrágio amplo. Assim, desse compromisso fundamental, resultam as características secundárias do "sistema coronelista", travestido no "mandonismo" (favoritismo, nepotismo), no falseamento do voto, na desorganização dos serviços públicos locais ou regionais. Consagra-se, assim, a propriedade da terra entre os fatores da liderança política local.

Na perspectiva de Nestor Duarte (1966), é a forma de apropriação e exploração (latifúndio monocultor) da terra que conforma a realidade econômica, social e política brasileira. Essa predominância latifundiária traz como efeito a submissão dos trabalhadores rurais a condições degradantes, evidenciando profundas repercussões políticas. De tal forma, faz-se imperativo superar essa contingência presente do feudalismo para fazer do país uma nação "moderna”. No entanto, reconhece o autor, é esta estrutura agrária desigual, configurada no latifúndio, que sustenta e apoia os esquemas e a lógica do poder. Em regra e na prática, havendo algum direito social conquistado, tais direitos não se estendem aos camponeses, como foi claro o caso da legislação trabalhista. Conclui-se, assim, a existência de um aparato jurídico-político, manejado porque se aloja no exercício do poder, que institui e reproduz uma narrativa ou conteúdo ideológico da propriedade fundiária, como e enquanto instituição de Estado.

Para a analista Elisa Pereira Reis $(1982 ; 1989)$, é na herança do patrimonialismo, desde suas origens europeias, que se pode compreender ao autoritarismo brasileiro. De forma específica, no contexto agrário, tal herança foi permanentemente reeditada. A secular estrutura de escravidão, para a autora, serviu para atrasar ainda mais a penetração do Estado no campo. Mesmo quando, formalmente chega-se ao fim da escravidão, em nada se altera o panorama do campo brasileiro. Assim, o projeto de modernização, quando é pensado para a agricultura brasileira, no regime militar, não alcança os pobres do campo. De outra perspectiva, os grandes proprietários 
sempre quiseram manter a alta produção em baixíssimo custo de trabalho, o que resultou em novas formas de escravidão. $\mathrm{Na}$ República Nova, de Vargas, pouco se fez para desmontar a estrutura de poder no campo. Manter inalterado esse sistema, aliás, era uma forma de não comprometer as posições das elites que sustentavam a coalização conservadora de apoio. $\mathrm{E}$, quando se entra no período militar, emerge uma onda de repressão que impactou a mobilização camponesa emergente. A questão agrária, então, torna-se uma questão militar, na verdade uma questão de polícia.

No entanto, pondera Reis (1989), mesmo ante tanta repressão, houve resistência que acabou fazendo que alguns processos fossem implementados em relação à questão agrária. Entre tais iniciativas, pode-se citar uma mais visível da atuação do Estado no campo, através de sua máquina burocrática, alterando uma prática que até então era essencialmente clientelista. Adota-se um novo modo de intervenção. No mesmo compasso, são implantadas políticas mais agressivas, de aspecto modernizante, resultando no surgimento de uma força de trabalho baseada no proletariado, acompanhada de uma intensa capitalização agrícola.

Nesse conjunto, ainda, por força de intensas mobilizações, começa-se um processo de incentivo à elaboração de políticas públicas, significando, ainda que de forma mitigada, melhorias de condições aos habitantes do campo, uma espécie de "cidadania limitada". Em tal contexto, o movimento sindical vai se fortalecendo, forjando, como novo ator social, espaços de participação e intervenção. No contraefeito desse contexto, uma onda de proletarização do campo vai deixando grandes levas de camponeses sem alternativa, fomentando uma espetacular mobilização humana para as "fronteiras”. Ainda assim, alguns grupos, não "encaixados" no sistema e na lógica da modernização, vão construindo alternativas de resistência e enfrentamento, dando voz, vez e objetivo nas lutas por acesso à terra e aos direitos, a exemplo do MST, em meados de 1980.

Contudo, o resultado desse processo histórico materializa-se numa complexa relação do Estado brasileiro com o campo, e sobretudo com os poderes oriundos do capital. Resta claro, nessa dinâmica, a contradição que se impõe, uma vez que tal modernização vai deixando cada vez mais sem 
alternativas o futuro da estrutura agrícola. Tão certo quanto a isso, contanto, é que sempre houve e sempre haverá resistência.

Para Cândido Grzybowski (1987), é de suma importância uma análise que investigue a forma pela qual a terra vem sendo apropriada e explorada no país. Tal pressuposto ajudaria na compreensão dos processos de articulação entre a extremamente diferenciada luta social no campo e o plano do debate político, propriamente dito. Ao mesmo tempo, sob tal enfoque, tornar-se-ia possível identificar qual seria o elemento homogeneizador possível dessas lutas sociais. Encontrado esse denominador comum, seria colocado em questão o atual padrão de desenvolvimento da agricultura, desvelando, inclusive, as contradições. Este padrão, concentrador da propriedade da terra e excludente da força de trabalho, é o mesmo que expulsa o homem da terra, reincorpora-o ao trabalho agrícola, na forma de trabalhador assalariado temporário.

No plano analítico e cognitivo, entretanto, Grzybowski entende que o estudo dos movimentos sociais do campo se apresenta de forma fragmentada e desordenada, sobretudo ante um processo de mudanças aceleradas. Ainda que constatando uma evolução de cenários, onde as políticas públicas passaram também a contemplar a questão do campo, não há mudança possível sem mudar a lógica do processo de desenvolvimento capitalista e de sua estrutura social, concentradora, predatória, mercantilizadora e privatizadora.

Assim, retóricas à parte, o Brasil tem sido um exemplo de social democracia de bem com o capitalismo. Em tese, há sempre um lado afetado socialmente, uma vez que a expansão capitalista no campo se apresenta ou na forma de expropriação (terra e produção), ou na forma de exploração (relações de trabalho e sobretrabalho). Nessa moldura, o campo, feudal na estrutura, encaixa-se sem rumor e sem traumas. De tal forma, a atuação dos movimentos sociais do campo deve ser analisada como parte dessas contradições entre as classes e a relação de forças, entre si mesmas.

Já para José de Souza Martins (1994), a história contemporânea se apresenta como a história da espera do progresso, reconhecida e revelada na persistência do passado. É, portanto, uma história inacabada. 
Imprescindível, nesse cenário, que a propriedade da terra se revista de uma dimensão política, tanto na estrutura em que se configura, quanto na atuação dos sujeitos envolvidos. De tal forma, a persistente aliança entre capital e propriedade da terra pode ser concebida como a "aliança do atraso". E foi assim, na aliança entre o escravismo e o latifúndio, verbalizada numa agressiva resistência social à mudança. Mas, também, é preciso admitir que, historicamente, as grandes mudanças sociais e econômicas no Brasil não estiveram relacionadas ao protagonismo de novos sujeitos sociais e políticos. No "mais do mesmo" dos personagens, os novos ideais e os radicais projetos políticos e econômicos reincorporavam os mesmos protagonistas. Sequer se davam o trabalho de alternância, uma vez que os arranjos sociais e econômicos cimentavam no poder político os mesmos interesses de classe, dos senhores de engenho, das oligarquias rurais ou da burguesia liberal.

Um dos elementares achados, por parte de setores da elite, foi o uso político das graves questões sociais. Graças a essa "tomada de consciência” é que se tornou possível instrumentalizar politicamente os dramas da miséria social e o uso político da seca, por exemplo. Há, sempre, afinal, uma boa justificativa para um grande projeto. A forma como essa justificativa é narrada, então, se amolda à conveniência de quem discursa. Um pouco mais tarde, por exemplo, no período do regime ditatorial, uma vez mais a aliança entre capital e terra não terá problemas para que ocorra a intervenção militar na questão agrária (GETAT - Grupo Executivo de Terras do Araguaia/Tocantins; GETSOP - Grupo Executivo para as Terras do Sudoeste do Paraná).

Relevante o indicativo do apoio da Sociedade Rural Brasileira (São Paulo) na preparação do golpe militar: foram os grandes organizadores da "Marcha da Família com Deus pela Liberdade). O que se viu no curso histórico, portanto, foram "construções arranjadas" suficientes, que garantissem uma base estável para a aliança com as "forças econômicas" rurais (aristocracia, oligarquia), garantindo, como resultado, uma aliança política, na forma de um conglomerado de poder.

Para Souza (1994), mesmo quando o "pêndulo da política brasileira" oscilava da ditadura para a democracia, ainda que empurrado pelas esquerdas, foi puxado pelas oligarquias. Isso restou cristalino na ideia da "Nova República" 
e, claro, também na elaboração da Constituição de 1988. Inclusive uma série de avanços em potencial, na legislação fundiária dos militares, foram revogados pelos constituintes, tangidos pela força conservadora do chamado "centrão".

No compasso dessa convergência, um dado fundamental na aliança de classe se estabelecia e fortalecia na atuação do Poder judiciário. E este é um elemento analítico pouco visível. Em regra, segundo Souza, os juízes das comarcas do interior, assim como os tribunais estaduais, começaram a pautar grande parte dos julgamentos em uma exegese articuladamente ambígua. Isto é, começaram a adotar o conceito de empresa rural, fixado no Estatuto da Terra, para interpretar a atividade de "empresa rural", pouco importando o concreto do conceito de produtividade, agora abstratizado.

Assim, opera-se uma sistemática onda de despejos, consolidando uma conduta coesa dos magistrados em defesa de concepções extremamente conservadoras da propriedade da terra. Anula-se, uma vez mais, a pressão dos movimentos do campo que esbarra na barreira feito cerca, que vincula capital e propriedade fundiária contra qualquer possibilidade de alteração substantiva na ordem social e política.

No resumo da ópera, a estratégica e estrutural aliança entre "capital e terra”, regimentada pelos militares, enfraqueceu a eficácia dos movimentos sociais que, à época, representavam uma possibilidade real de reivindicação, reconhecimento e ampliação dos direitos sociais em favor das classes marginalizadas, sobretudo as do campo.

Concluindo essa breve revisão teórica, considera-se relevante a obra de Alceu Luís Castilho (2012), baseado em pesquisa investigativa, retratando de forma objetiva a conexão explícita entre a lógica proprietária de terras e a política. Para o autor, há um "sistema ruralista no Brasil", que se caracteriza como um movimento suprapartidário. Trata-se de um sistema mais amplo que o conceito de "bancada", mas que reúne sob uma nova roupagem e ação a dinâmica do coronelismo e dos clãs políticos. Esse sistema teve uma atuação protagônica experimental, na aprovação do "Novo Código Florestal”, em 2012. Completamente à revelia dos alertas de importante grupo de cientistas acerca dos efeitos, o que se percebeu foi toda uma estratégia que visava, 
sobretudo, o avanço ruralista sobre as florestas amazônicas. Além disso, a aprovação da lei florestal (Lei no 12.651/2012) significou, na prática, além dos retrocessos e ameaças ambientais, uma lógica de anistia aos desmatadores.

Tais retrocessos, todavia, para além das negociatas e composições, em nome da "governabilidade", foram apresentados como um "consenso da sociedade" e como a salvação da pequena propriedade. Uma vez mais, portanto, aquilo que é retoricamente transmitido pouco corresponde ao que é efetivamente experimentado. Ou seja, velhas retóricas, editadas em novos contextos.

Como se percebe, o tratamento analítico relativo à grande propriedade ou ao latifúndio no Brasil estabelece consensos e ao mesmo tempo demarca nossa especificidade. Por outro lado, caracterizar o Estado brasileiro como patrimonial ou neopatrimonial não distancia de uma análise das nossas desigualdades, fincada na divisão de classes sociais. Na mesma linha de raciocínio, tal caracterização não nega a condição capitalista da nossa organização econômica. O que manifesta, contanto, é que, em termos históricos, políticos e culturais, essa característica patrimonial, seja no econômico, seja no político, põe em evidência nossas relações sociais, familiares, culturais, nossos valores e ideologias.

Nesse percurso, parece indissociável a ideia de perpetuação de um colonialismo, enraizado no patrimonialismo, mas que permeia um amplo leque de sentidos. É possível, assim, pensar na dimensão cultural dessa colonialidade mantida e sustentada em diversos e distintos campos da nossa formação histórica, econômica e política contemporânea.

Tais dimensões (patrimoniais e coloniais), incorporadas no organismo estatal ou nas relações e conexões estabelecidas, manifestamse por todos os cantos. Pode ser na utilização de recursos e poderes públicos para fins privados, pode ser nas inter-relações, recriando formas e conteúdos de cooptação, clientelismo, pode ser, ainda, influenciando ou ressignificando as formas de participação política. É nesse cenário que a representação conspurca-se na personalização do poder, que o exercício da justiça transmuta-se em concessões meritocráticas, ou que 
o cargo público converte-se em domesticação de privilégios ou interesses privados, ou corporativos.

A história é pródiga em registrar que há resistências, e que elas se consolidam, sobretudo, na força orgânica dos movimentos sociais, como resultado sempre inacabado da construção de uma outra consciência política, desvelando as contradições e as máscaras, por traz dos discursos e dos programas oficiais. Não sem dor, o parto dessa consciência, que vai se tornando mobilização, resistência e enfrentamento, se concretiza. Mas não deixa de ser indicativo, assim, o fato de que é no campo, como locus real e simbólico, que se processam os enfrentamentos e onde se constroem alternativas. Contra o que se impõe como sistêmico, opõe-se o movimento.

\subsection{ABORDAGENS APROXIMADAS: BREVE SUMÁRIO ANALÍTICO}

A questão agrária, refletida nos diversos matizes que a compõem, faz parte, secularmente, do cenário latino-americano, em suas lutas e resistências, na estruturação de uma ordem patrimonial, nas conexões políticas, nas muitas formas de violência, e também nas incessantes e multivariadas formas de resistência. Se o colonialismo histórico foi reduzido a processos demarcados, a colonialidade não. Vive de reproduzir continentalmente processos de apropriação de terra, territórios e bens da natureza, de manter uma agenda de exclusão social, que atinge socialmente aqueles grupos e povos, sempre relegados à margem, e vive também de impor uma narrativa de esquecimento e desmemória.

Em seu tempo e em seus territórios de atuação, Mariátegui, Gramsci e Faoro se propuseram a oferecer elementos de leitura, seja da realidade italiana, seja da realidade peruana, seja da brasileira. A contribuição desses autores na leitura política aponta para uma temática de fronteira, e por isso versa também sobre questões periféricas. Projetam olhares e abordagens, que direta ou indiretamente incidem em questões estruturais na análise dos processos de democracia, transformação e ação política, por parte dos setores organizados. Ajudam também a entender, na gênese, a gramática dos conflitos atuais, 
de forma a (des)montar enquadramentos, saberes e categorias, muitas artificialmente manejadas. Por isso mesmo, tal contribuição traz em muito um "olhar no espelho" das práticas coletivas, mas também um "olhar para dentro", das convicções, valores e paradigmas, que ainda nos mobilizam.

O que se propõe, agora, de forma parcial, e por isso pouco exaustiva, é aproximar alguns elementos que conjugam entre os autores, e que, portanto, projetam alguma reflexão sobre a práxis coletiva de nossas organizações.

1. O passado e a reprodução, pela via dos projetos de colonização, de estrutura feudal ou semifeudal, são analisados por nossos autores, sobretudo, nas formas de apropriação da terra. Impõe-se, nesse novo ordenamento, igualmente, novas formas de produção, direcionando, no plano econômico, para o atendimento às demandas da agroexportação rumo à metrópole e centros europeus.

2. Nos autores, a centralidade da questão agrária é moldada e regida pela lógica da expansão e acumulação capitalista de terras (latifúndio). O vínculo entre terra e poder sempre esteve muito próximo; são inerentes e delineiam, através de uma cultura patrimonialista, as regras de inserção/exclusão dos povos originários, ou camponeses.

3. A escravidão, como estrutura genética do capitalismo expansionista, ao lado da expansão proprietária, orienta o grande empreendimento, seja econômico (acúmulo de terras), seja rentista (bens e valor), seja no ordenamento social (manutenção legal e ideologicamente sustentada da massa de excluídos), seja, enfim, política (composição elitária, de uma aristocracia rural, em rota circular sobre as estruturas de poder).

4. As possibilidades de emancipação, transformação ou revolução são marcadas pelo contexto próximo ou aproximado. No entanto, a fragmentação social, os níveis de desigualdades regionais e as mediações instrumentais (tentáculos administrativos, poder religioso e intelectuais) tornam-se, em grande parte, obstáculos. Isso se dá pelo fato que tais sujeitos orgânicos pacificam o conflito na base (domesticam), em muito pela retórica 
da integração ou pelos arranjos ideológico-religiosos. Nesse contexto, alargam-se as margens para o clientelismo de ocasião, para os "favores-mútuos", docilizando qualquer possibilidade de insurgência.

5. A proposição do protagonismo dos camponeses e dos povos indígenas (Gramsci e Mariátegui) é suscitada como condição inevitável para um processo revolucionário. No primeiro caso, os camponeses da Itália meridional, desvencilhados das artimanhas da burguesia local, necessitam incorporar-se nas lutas revolucionárias proletárias, salvaguardando suas especificidades regionais e culturais. No caso peruano, o protagonismo indígena e campesino é inexorável, uma vez que a estrutura feudal-capitalista suplanta-lhes a expectativa, negando-lhes inclusive aquilo que os unia: formas de vida, terra, cultura, costumes.

6. No caso brasileiro, concordando com a estrutura feudal importada e aplicada, remanesceu na questão agrária o regime da grande propriedade e da escravidão. Os mais de três séculos de insistência desse regime moldou uma forma de organizar a sociedade, cuja elite dirigente, seja oligarquia rural, seja burocracia, sempre contou com a questão patrimonialista, como ponto de conjunção e interseção. Assim, o patronato rural torna-se patrimonialismo de Estado, e pode tornar-se "bancada". Importa, pois, que se mantenha a convergência de interesses econômicos e políticos, resguardados por um Estado, em essência, patrimonialista.

7. A intuição de Faoro, a respeito do patrimonialismo, transcende em muito a perspectiva de análise centrada no Estado, estamental-patrimonialista. $\mathrm{O}$ patrimonialismo, na verdade, incide na análise das relações entre o público e o privado, mas incide também nas conexões Estado-cliente, nas suas multiplicadas e variadas formas. Grosso modo, cria-se, na sociedade brasileira, o patrimonialismo como cultura política, que invade todos os espaços, todos os cenários e sujeitos. Ao criar e recriar, como forma de pensamento e cultura, o patrimonialismo gera práticas 
que interferem nas formas de participação, ou processos participativos. O patrimonialismo, enquanto cultura, também mobiliza imaginários, sobretudo entre as classes subalternizadas, quando projetam suas expectativas ou objetivam seus afazeres em ideias criadas e reproduzidas: o "sonho de ser proprietário", "a terra como status social e mais valia” etc. O ideário proprietário é a senha prática da cultura do patrimonialismo, que pode estar nos grandes projetos ou na propaganda governamental da "terra de oportunidades". Pode se constituir em grandes narrativas, "Eldorado amazonense", ou pode embalar e mobilizar a quimera do colono-migrante que veio "tentar algo melhor". Ou seja, nossos cinco séculos de história, enraizados na assimétrica e substantiva desigualdade agrária, germinaram e por muito tempo alimentaram a utopia proprietária. Não que reinasse absoluta, porque, para os povos originários, indígenas, quilombolas, ribeirinhos, coletores, a ideia de reconhecer-se na terra, de a ela pertencer, fazia emergir outra cosmovisão, tão política quanto a outra, e que engendrou e engendra resistências, lutas e conquistas: a "utopia camponesa". E ela, no campo de debate, de enfrentamento e disputa, se verbaliza nos "gritos de ordem" e se materializa nas ocupações, resistências, defesa da posse, atuação política, em vários níveis e instâncias. Ainda que essa intuição não estivesse, por não ser o objetivo, presente em Faoro, foi detectada e analisada tanto por José Carlos Mariátegui quanto por Antonio Gramsci.

8. $\mathrm{Na}$ perspectiva de vários pensadores brasileiros, constrói-se o consenso de que, sob a égide da condição feudo-colonial, criaram-se as condições de possibilidade de instalar e reproduzir no Brasil não só a escravidão, como todos os seus efeitos. Transformada em cultura, essa condição colonial ganhou substrato, principalmente na classe proprietária (grandes propriedades). A terra, assim, não seria apenas um bem material, mas um capital 
social ${ }^{6}$, ideológico e político, que organicamente repropôs, sempre que necessário, a dinâmica do poder. No Estado, tal poder encontrou também as condições efetivas de sustento e reprodução e, mais que isso, a garantia da inalterabilidade estrutural e social. Nessa dimensão possessiva de organizar economia e política, traçaram-se compromissos fundamentais, direcionados para apropriação de bens e pessoas - e posteriormente do público -, e para a exploração, criando e recriando condições subumanas de trabalho, ou precarização de condições de vida. Mas se reproduziram também as dinâmicas de reincorporação que, embaladas por retóricas promessas, mantiveram e mantêm, em condição subalternizada, grande camada da população brasileira.

A sumarização aqui proposta não se presta, enfim, para capturar o sentido da ação coletiva no entorno exclusivo da questão agrária. Essa é, ou tem sido, uma mola propulsora para os processos de organização e mobilização dos movimentos e segmentos sociais do campo. Assim, pretendeu-se não recopilar, de forma inconsequente, a densidade teórico-interpretativa da questão agrária no Brasil, mas acenar para o fato de que há leituras instrumentais importantes, que clivam a abordagem.

De igual forma, buscou-se, na mesma linha de Gramsci, Faoro e Mariátegui, detectar os elementos essenciais, sem os quais, a própria interpretação do Brasil e de seus fenômenos sociais resultaria míope ou limitada. A percepção desses elementos resulta, portanto, em uma abordagem dialógica e complementar. Não há ambiguidades, assim, em constatar nossa condição colonial (feudal), que se perpetua em privilégios proprietários, normatizados como direitos. De igual forma, há que se auscultar as "narrativas patronais", visto que buscam legitimar não só as novas versões do desenvolvimentismo, como impor o "consenso" da precarização do campo,

\footnotetext{
${ }^{6}$ A ideia de capital social ampara-se em Pierre Bourdieu (1998) que a define como um conjunto de relações, estas mais ou menos institucionalizadas, que vinculam determinado grupo. Tais relações se estabelecem em graus de confiança e traduzem, nesta união, não só propriedades comuns, mas também ligações duráveis e úteis. Para maior aprofundamento, ver Pierre Bourdieu (1998).
} 
como sacrifício natural para o progresso econômico. E, enfim, perceber, igualmente, que a "arquitetura proprietária" arma-se de uma "cultura" de privilégios, tolerante com os desmandos, justamente para assegurar os interesses de um "parlamento do patronato".

Por isso que a revisão teórica, aqui proposta, não tem o condão de ampliar as margens de compreensão e análise, mas justamente afunilar elementos que possibilitem refletir, a partir dessas categorias, a atuação dos movimentos sociais do campo, na fronteira de relação com o Estado. Essa abordagem acerca do Brasil agrário, na perspectiva dos intérpretes apontados, indica tanto fontes quanto margens. Fontes, uma vez que esse olhar para a história é crucial para cartografar o lugar de fala e de ação dos movimentos sociais hoje. Margens, porque, para além das complexidades que dão o contorno do fenômeno, o que fica claro é a perspectiva dialética desse confronto que, no Brasil, se estabelece entre a sustentação e a ruptura. $\mathrm{Ou}$ seja, entre a insistência das estruturas coloniais e o rompimento com essa lógica sistêmica de dominação, uma insubordinação, portanto.

\subsection{CONTRAPONTO ANALÍTICO 2: O MITO DA AUSÊNCIA DO ESTADO}

O mito da "ausência do Estado" precisa ser revisitado, no contexto dos processos de colonização. Tem sido um "consenso perigoso" associar a pobreza ou a marginalização de zonas de fronteira, sua falta de incorporação aos processos econômicos, sobretudo, a um mito: "a ausência do Estado". Assim, parte-se da ideia de que o "abandono estatal”, seja por parte da mediação de suas instituições, seja por meio de programas de fomento e desenvolvimento, se tal não tivesse ocorrido, a situação teria sido outra. Pressupõe-se, contanto, a necessidade de desmistificar essa noção da "ausência do Estado", tentando compreender como historicamente esse Estado tem se feito presente continuamente. Tal presença, de forma expressa ou implícita, é percebida nas ações e omissões dos grupos ou segmentos que incorporam ou encarnam o próprio Estado, o constituem e o compõem. 
Assim, distintas e diversas narrativas compõem o sentido da imprescindibilidade do Estado. Tais narrativas, aliás, se materializam e são verbalizadas igualmente nas imagens expressas pelos atores políticos, nas quais a mediação do Estado é sacralizada como caminho de mão única, que ao mesmo tempo esconde e expõe. Esconde as tramas estruturais da construção mítica e mágica da ordem do poder e expressa a imagem de redenção pela figura do Estado necessário. A prática discursiva, portanto, ganha força constitutiva e mobilizadora, já que as grandes massas acabam se mobilizando mais facilmente pela força da imaginação que pela força física, como ensinava Ernst Cassirer (2003).

Não só a construção geográfica ou geopolítica, mas a construção de certo tipo de ordem social, acaba sendo definida por essa presença do Estado. As próprias categorias políticas, como se tem demonstrado, as escolhas e as formas de organização social, perceptíveis nessas regiões de fronteira, são tidas, não ingenuamente, como "territórios de exceção". Em tais espaços, com trato político e jurídico, na forma de exceção, ajustes e tolerância, constituem, ao contrário do senso comum, não uma ausência, mas uma presença programada do Estado.

$\mathrm{Na}$ região amazônica, a presença do Estado revestiu-se muitas vezes de um potencial simbólico, canalizado sempre pela ação estratégica de algum órgão desse Estado. Nessa região, portanto, o Grupo Executivo de Terras do Araguaia-Tocantins (GETAT) simbolizou muito mais que uma orientação de Política pública. De igual forma, esse foi o desenho, por exemplo, da Superintendência de Desenvolvimento da Amazônia (Sudam) e, sobretudo, do Instituto Nacional de Colonização e Reforma Agrária (INCRA), a partir de 1970. Foi por meio destes órgãos que, de forma direta ou indireta, o Estado se fez presente, projetando, definindo e efetivando as iniciativas de governo que demarcariam profundamente o espaço econômico, físico, político ou social da região. Com essa "presença" é que as mobilizações massivas (migrações), com grandes deslocamentos regionais, se dinamizaram. E foi por essa intervenção, no que se fez ou no que se omitiu, deliberadamente, que o Estado, por meio de seus programas, 
criou as condições para a instalação de grandes empresas agropecuárias e dos grandes latifúndios na região.

Encerraro debate sobre a inação do Estado como decorrente da "ausência" do ente estatal, responsável pelas políticas públicas, corresponde a um erro de análise irretratável. Margarita Serje (2012) aponta que essa lógica consiste em um dispositivo de desenvolvimento do capitalismo com objetivos claros de reorganizar o espaço com propósitos explicitamente políticos ou econômicos. A lógica do Estado ausente, portanto, comporta uma função social muito concreta, sobretudo de manter encoberta uma série de possibilidades políticas de intervenção, controle e submissão à lógica capitalista mundial.

A Amazônia, locus concreto, desvela-se como um espaço-lugar onde redefinem-se essas estratégias estatais, impõem-se as dinâmicas territoriais e constitui-se ambiguamente como "espaço de inclusão" e de penetração (colonização). Isso se faz mediante dispositivos concretos (categorias políticas e jurídicas), reconstruindo determinada ordem social, como espaço legitimado de intervenção.

No mito do Estado ausente, as narrativas primeiras são de que tal "ausência" é pressuposto de uma violência que ali se instala, como forma de solução de conflitos, sempre coercitivo. Esse cenário, na verdade, acaba gerando as condições de possibilidade para o exercício de práticas clientelistas. Justifica-se, desse modo, todo tipo de intervenção, e é nesse contexto que sobretudo as elites locais - apropriando-se do Estado - são percebidas como se Estado fossem. Esses “espaços de excepcionalidade”, definidos pelo Estado, acabam conferindo a este mesmo Estado um poder de exercício revestido de total impunidade. Assim, esse espaço excepcionado acaba se tornando lugar também do "direito de exceção".

A forma de presença estatal na Amazônia, induzindo uma fórmula de colonização dirigida, atenua inclusive os horrores e a barbárie dessa ação. Visibiliza tal cenário nos males causados aos povos e comunidades tradicionais, no seletivo processo de concessões e favores e na arbitrária escolha de beneficiários (terra e investimentos). É importante anotar, ainda, que, cumprindo o Estado a essencial tarefa de reproduzir a ordem capitalista, no ordenamento fundiário, nos modos de produção e nas formas de relação 
social, ele contará historicamente com os grupos de poder local, que corporificam esse Estado no exercício de seu poder e soberania.

A narrativa do "mito da ausência do Estado" cuida de fazer crer que tal ausência é fator de desordem, e é onde impera a lei do mais forte. Assim, tais territórios acabam representando um obstáculo para a integração nacional e para o desenvolvimento nacional. É donde emerge a ideia do "vazio demográfico", ou seja, dos "espaços vazios". Nesses espaços - vazios somente na perspectiva cartográfica - os habitantes originários, as comunidades tradicionais "desaparecem". Ou, se aparecem, se caracterizam como pessoas marginais, carentes e sem capacidade de pensar seu próprio futuro ou de tomar decisões sobre seu desenvolvimento.

$\mathrm{Na}$ perspectiva do Estado moderno, portanto, é nesse "vazio demográfico" que o poder estatal será exercido, instaurando nova ordem, "domesticando" os humanos e a natureza, imprimindo ali uma nova ordem econômica, social e política. Incorpora a essa estratégia a dinâmica da acessibilidade, ou seja, é o Estado que faz a mediação do acesso dos "selvagens" ao mundo moderno, à civilização. Essa incorporação, por outro lado, faz referência ao potencial econômico que tais regiões escondem, riqueza esta que precisa ser colocada a serviço de uma estratégia de integração e de desenvolvimento.

Voltando às narrativas, é importante notar que há deliberadamente uma prática discursiva, por parte do Estado, que produz contextos de interação com essas regiões. Trata-se de um verdadeiro dispositivo de "nomeação", através de imagens e metáforas, como uma espécie de produção simbólica, que tanto "reifica" quanto "sataniza" essas regiões por meio de reiteradas categorias (Serje, 2012). Assim agindo, implementam-se todas as condições, fundadas nesses consensos, no sentido de desenvolver tanto a gestão de pessoas quanto do ambiente, caminho explícito da geopolítica instituída.

O caráter seletivo do empreendimento colonizador dependerá, para tanto, de um autêntico exercício de conveniências e inclusões. São aqueles (alguns) que cuidarão em "ser o Estado", no exercício de gestão das políticas possíveis. Constituem os heróis, militares, pioneiros, que simbolizarão 
essa presença do Estado, como um verdadeiro e manifesto propósito de sedimentar e dar sustentação à lógica da expansão do Estado, e não a articulação regional. As desigualdades regionais, assim, se expressam no iníquo processo de exclusão das populações locais, da imposição do silêncio e da invisibilização dos problemas estruturais da região.

Nenhuma medida, entretanto, se efetiva, sem um anteparo jurídico que assegure e legitime essa ação estatal. É a forma, moldada em figuras jurídicas, com que se enquadram as medidas políticas e administrativas. No caso estudado, no Estado de Rondônia, foram os projetos dirigidos de colonização, as concessões públicas aos empreendimentos privados, a criação de estruturas administrativas, entre outras, essa série de medidas que tornaram possíveis a implantação macroestrutural do Plano de Integração Nacional, como desenho geopolítico na região.

Por tais dispositivos, eliminam-se "obstáculos" pelo caminho, sejam eles humanos ou da natureza, para atender às necessidades de intercâmbio, comércio e expansão do capital. A própria concepção de infraestrutura, como premissa de desenvolvimento regional, acaba se convertendo em obstáculo. Por essa lógica, as estruturas como rodovia, portos, rotas aéreas, são implementadas respondendo, muito mais às necessidades de expansão do capital do que às demandas regionais. Não se trata de viabilizar articulações regionais, ou de promover intercâmbios e aproximações entre regiões vizinhas. Para a lógica do investimento estatal, acaba, assim, proporcionando um efeito de inacessibilidade para os próprios habitantes. Efeito este, percebido, paradoxalmente, como indícios de inação ou ausência do Estado (Serje, 2012).

Ocorre que, para que se concretize a reprodução e expansão do capital, não se impõem limites ante as agressivas iniciativas do desenvolvimento. A lógica expansionista, igualmente, não comporta limites, análises, diagnósticos e estudos de efeitos ou impactos. Tudo é regido pela eficiência e obtenção de interesses a curto prazo, não importando custos sociais ou ambientais. Nessa perspectiva, a atuação intervencionista interage com os grupos de poder local, que representam o Estado, sua causa e seus projetos. Nas "fronteiras do progresso", são tais grupos os arautos do desenvolvimento. 
Trata-se, pois, de um amplo processo de extrativismo das riquezas, efetivado em um contexto reeditado de colonialismo, sob a retórica do desenvolvimentismo e da integração nacional. A forma mais visível e evidente desse processo de mercantilização dos bens naturais, hodiernamente, reflete-se nos megaprojetos. São eles que demandam e obtêm grandes investimentos públicos e vastas extensões de território, reconfigurando o espaço humano e o espaço natural ao seu redor.

Impõe-se uma dinâmica de desterritorialização, como resultado imediato de outras formas capitalistas de produção, especialmente a monocultura e o agro e hidronegócio. Consolida tal "idiossincrasia estatal capitalista”, por arranjos estratégicos que potencializam - via um esquema de concessões, por meio de contratos - uma política de "enclaves" capitalistas, caracterizados pela lógica da apropriação e exploração dos recursos naturais e humanos. De tal forma, o ponto nodal da reprodução capitalista desenha-se na forma política estatal (Mascaro, 2013).

No plano administrativo, mais que entraves geográficos, no aspecto da inserção colonizadora, são os grupos humanos que se interpõem como problemas ou obstáculos. Nesse aspecto, cabe ao Estado uma dinâmica de práticas específicas de colonização (domesticação ou pacificação). A questão das diferenças (modos de ser, fazer e relacionar) é tratada politicamente, por meio de práticas de homogeneização. Mais que um Estado ausente, é o Estado que passa a implementar mecanismos e dispositivos políticos de "normalização" para as comunidades e para suas formas de vida: reconhecimento quilombola, demarcação de terras indígenas, regularização fundiária etc. Trata-se de categorias formalizadas e fundamentadas em um abstrato "Estado de Direito", que dá direito ao Estado de classificar, ordenar e normalizar as vidas humanas, territórios e os bens naturais.

$\mathrm{Na}$ forma imposta de disciplina (legalização) e domesticação (civilização), dimensiona-se uma postura paternalista, por parte do Estado. Exemplificando, mais que uma ausência das instituições público-estatais, ocorre uma transferência das funções de tipo "social" para organismos de tipo "assistencial", que tendem a reproduzir, mais que superar, as condições de exclusão e marginalidade (Serje, 2012). 
A naturalização dessas relações é imposta muitas vezes por consensos pragmáticos, estrategicamente elaborados. Rescindem-se os enfrentamentos na arena do debate, por meio de uma inserção domesticadora dos órgãos de gestão, como intervenções legítimas ou legitimadas. Assim, naturaliza-se a conquista de direitos ao cumprimento de determinados procedimentos, aplicando-se formas e meios para atingir objetivos e uma coexistência razoável de interesses e liberdades.

No cenário em perspectiva, não escapa do confronto analítico, portanto, a gestão da Fundação Palmares ${ }^{7}$ no reconhecimento das identidades e direitos quilombolas, da atuação de setores não governamentais e governamentais, no reconhecimento das demandas territoriais indígenas. Essa dinâmica ilustra, ainda, a atuação setorizada de órgãos jurídico-administrativos, e do próprio Incra, no sentido de se interpor, enquanto condição de possibilidade, na efetivação de direitos das comunidades/povos tradicionais, bem como dos camponeses. Na relação Estado-Sociedade, assim, vai subsumir uma forma de atuação paternal-clientelista disciplinada e naturalizada pela retórica estatal.

Há que se anotar, ainda, que a doutrinação estatal, sob a nuance da domesticação, anda de mãos dadas com as práticas de repressão e coerção, públicas ou privadas. A atuação contratada das práticas privadas de violência contra camponeses e povos tradicionais conta muitas vezes com a "vista curta" dos agentes estatais, quando não, com a própria cooperação (Serje, 2012). Em casos assim, a "naturalização da violência" está longe de caracterizar-se como decorrência de um "Estado ausente". Pela ação ou pela omissão, a presença do Estado caracteriza-se por conciliar violência com "formas toleráveis" de coerção.

Para Margarita Serje (2012), uma dessas formas de coerção reside na "obrigação de consentimento implícito", nas chamadas "consultas prévias" (audiências públicas), sobretudo em relação a pautas que envolvem

\footnotetext{
${ }^{7}$ Conforme se autoidentifica, a Fundação Palmares é uma Instituição pública que tem como enfoque a promoção e preservação da arte e da cultura afro-brasileira, fundada em 1988. Está vinculada ao Ministério da Cultura e presta serviços institucionais, em especial a certificação da autodeclaração das Comunidades remanescentes de quilombo.
} 
direitos territoriais indígenas. Ocorre que o direito reconhecido de ser informado pressupõe não o direito de decidir sobre projetos que impactem os interesses e a vida dos grupos coletivos, muito menos sobre projetos de "interesse nacional".

Nota-se, aqui, que o pano de fundo dessa lógica baseia-se, evidentemente, na ideia clássica do assimilacionismo e da homogeneização insuperada. Põe-se em xeque a possibilidade de considerar os interesses das minorias, tanto na elaboração quanto na interpretação, ou seja, na aplicação de um Direito oficial ou Público, que reconheça e efetive tais direitos, que afirme e promova as diferenças como direitos fundamentais.

No esforço de compreender e desmistificar esse sentido de presença/ ausência do Estado, Carolina Tedesko (2010) se propõe a analisar a questão. Para a autora, a "presença ausente" do Estado ocorre quando essa presença ignora e não envolve a sociedade civil na produção das políticas públicas. Identifica-se, aqui, a incapacidade por parte do Estado de gerar respostas às necessidades da população, sobremaneira, dos setores à margem dos projetos oficiais. Por outro lado, a "ausência presente" do Estado opera-se na descentralização (terceirização) da produção de políticas públicas, como forma de o Estado desempenhar seu papel específico na produção do espaço e na construção social. Em vez de exercer sua forma de atuação, o Estado a modifica, delegando tal função.

$\mathrm{Na}$ realidade, há uma função social por trás do mito da ausência do Estado. A instrumentalidade efetiva dessa narrativa se estipula como condição de possibilidade de uma série determinante de estruturas e situações políticas. Exemplo claro disso é o fato de que, ao buscar manter "invisível” a ação do Estado, implicitamente supõe que aqueles grupos que corporificam o Estado estão imunes na sua ação. Ou seja, não precisam prestar contas de suas ações na região. Ainda que generalizada e aparente superficial, essa afirmação implica admitir que, nas "lacunas" de atuação do Estado, as responsabilidades e responsabilizações se diluem. O "vácuo" de democracia instiga comportamentos públicos de exceção, gerando nesses "vazios de Estado", situações que, em maior ou menor grau, "justifiquem” 
inclusive violações do Estado de Direito. Nesse caso, as medidas de exceção são facilmente instrumentalizadas.

O contraponto dessa estratégia geopolítica assume dimensões que transcendem os aspectos econômicos. É nesse contexto que nutrir expectativas de forma acrítica, na tutela do Estado, resultaria muito mais em perpetuação de interesses, no binômio Estado-cliente, que em possibilidades de compreender os processos como não lineares, e em profunda dinamicidade, o que requer consciência crítica, mobilização, organização e atuação.

Por isso, o "filtro econômico" é instrumentalizado pelo Estado como via inexorável de sustentação da ordem estabelecida. Ao passo que, na perspectiva dos setores marginalizados, em via de organização e mobilização, essa perspectiva deve transcender, no sentido de desvelar, os paradoxos dessa ordem mantida. À luz desse desvelamento, sucede a ruptura, pelo protagonismo social, com o padrão de conservadorismo mantido. Ante tal processo, abrem-se as possibilidades históricas, mediante o déficit histórico das promessas incumpridas da República, do Estado democrático e do Estado Social de Direito.

Nota-se que, seja naquilo que os setores sociais reivindicam como efetivação de direitos já constituídos, seja na demanda por proteção social, a presença ou a "ausência” do Estado demarcam uma ordem constituída. Essa ordem acaba sendo legitimada, de forma expressa, pelos aparelhos legais de controle e coerção, representados neste Estado. Mas também é legitimada de forma simbólica, quando se tenta naturalizar as assimetrias, por meio de práticas e procedimentos "oferecidos" e "normalizados", onde muitas vezes a vítima se transforma em cúmplice.

Assim, cria o Estado essas estruturas cognitivas, que são estruturas de "convencimento" e de submissão, traduzidas na forma de relações de força e relações de sentido, em termos bourdieanos, "o poder simbólico do Estado”(Bourdieu, 2014, p. 227). Importante recordar que, para o sociólogo francês, é o Estado o maior contribuinte para a produção e reprodução de determinada ordem simbólica, através de uma série de ritos ou procedimentos que definem essa ordem social. 
Observe-se, a título de exemplo, o caso retratado a seguir. Em 2016, o Conselho Nacional de Direitos Humanos (CNDH) realizou uma missão no Estado de Rondônia, com o objetivo de identificar, mapear e analisar a realidade exponencial de conflitos agrários no campo, no Estado. Buscou, para fins de encaminhamento, explicitar, de forma justificada, uma série de recomendações ao Estado e suas instituições, no sentido de mediar soluções para tal realidade.

Gráfico 1 - Recomendações ao Estado e Instituições públicas de Rondônia - CNDH, 2016

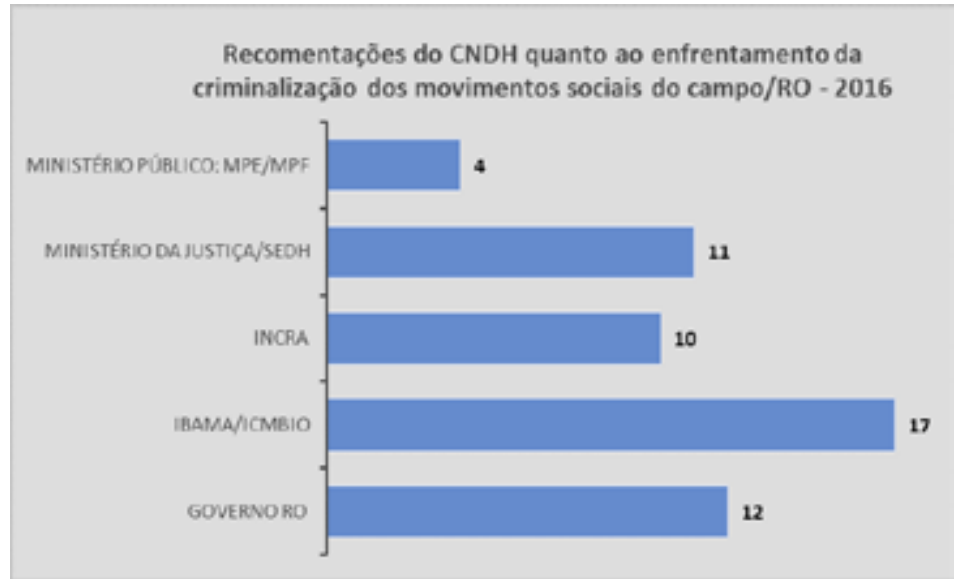

Fonte: Própria Autoria com base em CNDH/Relatório de missão, 2016

Trata-se, numa expressão inclusive contraditória, de relembrar, ao próprio Estado, as suas funções. Poder-se-ia dizer ainda que remete à ideia de que se torna legitimamente possível admitir que há, por parte dos fatos, uma narrativa em disputa, uma vez que a realidade dos fatos e sua versão acabam dependendo da localização do narrador. Assim, se compreende que muitas vezes é na lógica do funcionamento das instituições, do espaço burocrático, que se encontra a racionalidade estatal, e não em seus princípios sociais, políticos e republicanos (Bourdieu, 2014).

As formas coercitivas de intervenção do Estado, nesse contexto, passam a ser legitimadas. Esse foi, por exemplo, o traço característico da presença do GETAT (Grupo Executivo de Terras no Araguaia e Tocantins) e do GEBAM (Grupo Executivo para a Região do Baixo Amazonas), em 
1980, que tinham como Presidente um representante da Secretaria-Geral do Conselho de Segurança Nacional. Na contraface dessa estratégia, a própria violência privada encontra, por parte do Estado, tolerância. Resulta, pois, que a violência passa a ser, em si mesma, um eixo do modelo econômico, com a finalidade de manter uma situação de "anarquia ou caos" necessária, para articular as estruturas do capitalismo em expansão.

É sob tal paradigma de expansionismo global que se sistematizam os vínculos das estratégias locais com o sistema global de ordenamento social e territorial, visíveis no fundamentalismo jurídico da propriedade privada em suasdeterminantes (apropriação,privatizaçãoe concessão desmedidade terras públicas a particulares). Da mesma forma, isso se opera no ordenamento/ concentração geográfica das áreas de produção e mercado de trabalho. É o que se percebe, igualmente, na edição/reedição de categorias jurídicas, na forma de regras articuladas à modelagem dos interesses capitalistas: "fronteiras agrícolas", "empresa rural”, "Amazônia legal", "Terra legal” etc.

O dirigismo estatal, no caso dos processos de colonização em Rondônia, tangia-se por um claro favorecimento à grande propriedade, considerando a pequena produção como uma atividade marginal (Turchi, 1981). Cumpria-se assim uma dupla função, aparentemente contraditória. De um lado, esse Estado, como agente econômico das classes dominantes, criava condições para a expansão do capitalismo, por outro lado, como agente político, cumpria a função de legitimação, promovendo, enquanto agente político, a articulação dos distintos interesses de classe. Tais interesses se consumavam na forma de arranjos e ajustes sociais, de modo a não criar embaraços ao processo de acumulação capitalista na região. De tal forma, pelas “despesas sociais" implementadas, buscava-se evitar/mitigar pressões e reivindicações dos setores mais explorados, criando uma sensação de atendimento estatal às necessidades de tais grupos. (Turchi, 1981, p. 302).

Dessa forma, manteve-se intocado o sistema de propriedade no campo, naquilo que costumeiramente nomeou-se como "modernização conservadora”, excluindo, pela política adotada (colonização), qualquer possibilidade de efetivar um amplo e democrático projeto de reforma agrária ou de democratizar o acesso à terra. 
Como se constata, no plano estrutural, tal situação ativa e alimenta a narrativa da "ausência do Estado", no sentido de garantir e manter e retroalimentar a história hegemônica de um único setor, o da classe dominante, como afirma Florestan Fernandes (2005). Cerceia-se o acesso à inclusão social, pelos direitos básicos, mantendo-se, ao mesmo tempo, a subordinação ao capital externo, sua lógica e suas diretrizes. Os repertórios que refletem essa realidade mantêm-se pelos pilares dessa composição Estado-capital, e são recorrentemente reeditados e reinseridos, sempre que o contexto desafia a conveniência hegemônica ou dominante. 


\section{MOVIMENTOS E CENÁRIOS: PROCESSOS DE ENFRENTAMENTO E RESISTENNCIA NAS LUTAS AGRÁRIAS EM RONDÔNIA}

A busca pela genealogia dos movimentos sociais do campo em Rondônia, além de demonstrar o contexto onde se desenvolvem as práticas coletivas, ajuda a compreender também as condições objetivas, tanto socioeconômicas quanto políticas de tais práticas. Os elementos dessa compreensão e análise serão especialmente buscados em Felske et al. (2014), Santos (2001), Oliveira (1994; 1988), Fernandes (1999; 2005), Martins (2009) e Souza (2011).

Em regra, os conflitos agrários "acompanharam" os Projetos de colonização, tanto aqueles dirigidos pelo Estado, quanto os da iniciativa privada. Em janeiro de 1960, dá-se início à construção da BR 364, no trecho entre Cuiabá e Rio Branco. Em onze meses, o projeto foi concluído e oficialmente inaugurado pelo então Presidente Juscelino Kubitschek, em fevereiro de 1961 (Théry, 2012). Estava, então, estruturada a maior condição instrumental que tornaria possível a implantação dos Projetos de colonização na parte noroeste do Brasil. Comentava-se, em Rondônia, à época, que "depois dela (Rodovia), esta terra nunca mais seria a mesma”.

A luta política, protagonizada por distintos segmentos sociais, indica que ainda não é possível falar em movimentos sociais, por falta de seus elementos organizacionais e capacidade mais elaborada de articulações em torno de uma pauta política. No entanto, esses movimentos expressam um importante campo onde ações coletivas, ainda que pontuais, demarcavam ao mesmo tempo um campo de "(re)ações coletivas ao projeto de colonização”, impetrado pelo Estado brasileiro.

Assim posto, indica que a questão agrária, sinalizada e demarcada pela colonização, não é só uma questão social, mas essencialmente política. Em termos bastante consensuais (Ianni, Martins, Fernandes, Oliveira), são lutas assim, de enfrentamento e resistência mobilizada, que problematizam e expõem as contradições da própria lógica de expansão 
do capitalismo pela apropriação e concentração de terras. Isso resulta caracterizado na maneira como essa terra é arrecadada e discriminada, sobretudo, na forma como é destinada. Tal destinação, em regra, busca privilegiar os empreendimentos agropecuários e as licitações de grandes áreas - diretamente ligada aos objetivos macropolíticos, tecidos pelo ideário desenvolvimentista do Estado brasileiro.

$\mathrm{Na}$ reação das lutas por parte de posseiros e ocupantes, ressoava a "utopia proprietária", ou seja, no sonho do despossuído, a terra prometida, a realização de seu anseio em se tornar proprietário, criador de gado, "alguém na vida”. Na dimensão cultural, portanto, tais reações evidenciavam sim um enfrentamento, mas acentuava também, e sobretudo, a vontade de inserção, ainda que tardia, na lógica capitalista de se tornar proprietário. Portanto, em grande parte, tais resistências são desconstituídas de um ideário, ou ideologia de democratização da terra, da produção cooperada, ou de laços mais profundos de uma utopia camponesa. Trata-se, muito mais, de desnudar as contradições do próprio modelo capitalista adotado e incorporado aos projetos de colonização.

\subsection{PELA POSSE E OCUPAÇÃO: AÇÃO E REAÇÃO NAS LUTAS SOCIAIS DOS ANOS 1970}

Coube à iniciativa privada os primeiros empreendimentos da colonização. Assim, a partir de 1964, a empresa Calama S/A, pretensamente amparada na regularização de concessão de antigo seringal, dá início ao processo de comercialização de terras para fins de instalação de colonos na região central do território (Felzke, 2014). A área pretendida foi dividida em sete grandes glebas, denominadas pelas letras do alfabeto (A a $G$ ). A Gleba $G$, no entanto, não seria comercializada no primeiro momento, por claras razões de especulação imobiliária (Cunha, 1985). A empresa, cujos proprietários eram do norte do Paraná, mantinha fortes vínculos com o governo de então, arrogando uma área de 1.084.627 hectares de terra.

Com a notícia de que provavelmente as terras da Calama eram terras públicas, teve início a ocupação, e também os conflitos que perduraram 
até 1982, quando ocorreu a desapropriação da Gleba G, para fins de regularização fundiária, mediante uma vultosa indenização. $\mathrm{O}$ movimento de resistência da "Gleba G" insere-se, portanto, como um dos primeiros movimentos de resistência dos posseiros e sitiantes, perante a repressão violenta promovida pela colonizadora. Registre-se, ainda, o quanto essa prática de "compensação" da grilagem de terras públicas (via indenização) seria utilizada posteriormente, por parte do Estado.

No emblemático ano de 1970, o gerenciamento militar do empreendimento de colonização propagaria suas principais estratégias. Restaura-se o Incra, que é instalado em Rondônia naquele ano. Através de Decreto-Lei (1.106 de 16/06/1970), oficializa-se o Plano de Integração Nacional, assinado pelo governo Médici, traçando as principais estratégias geopolíticas da colonização. Assim, estavam dadas as condições de possibilidade para implementar as iniciativas governamentais (estruturas), econômicas (investimento e financiamento) e político-estratégicas (forma de integração da região).

Conforme a análise de Octávio Ianni (1979, p.81), o básico da estratégia governamental era reduzir os tensionamentos sociais, no contexto da modernização agrícola do Sul e Sudoeste, com falsas promessas. E, assim, "distribuir alguma terra para não distribuir as terras". Com a criação da Superintendência do Desenvolvimento da Amazônia (SUDAM), em 1966, incorporada à mesma estratégia de colonização, o foco era promover incentivos fiscais, subsidiando os interesses dos investidores privados, descerrando a cortina que encobriria toda a situação de conflitos, então já existentes.

Consolidando o favorecimento aos grandes monopólios, com a ajuda da "mão coercitiva" do Estado e da violência privada, a grilagem de terras públicas efetiva-se como a principal marca do período. E, assim, sob a batuta diretiva do Estado, via Incra, poderiam ser criados os Projetos Integrados de colonização (PIC), os projetos de assentamentos dirigidos (PAD), os Projetos de Assentamento Rápido (PAR), as grandes licitações, a custo mínimo (via contratos), e os incentivos e subsídios aos investidores privados. Destaque-se que o empreendimento - que foi o Projeto de colonização, seletivo e excludente, na forma e no objetivo - estabeleceu a lógica da colonização como um programa de contrarreforma agrária (Ianni,1979; Mesquita, 2001). 
Figura 1 - Áreas públicas destinadas a projetos via licitações ${ }^{1}$

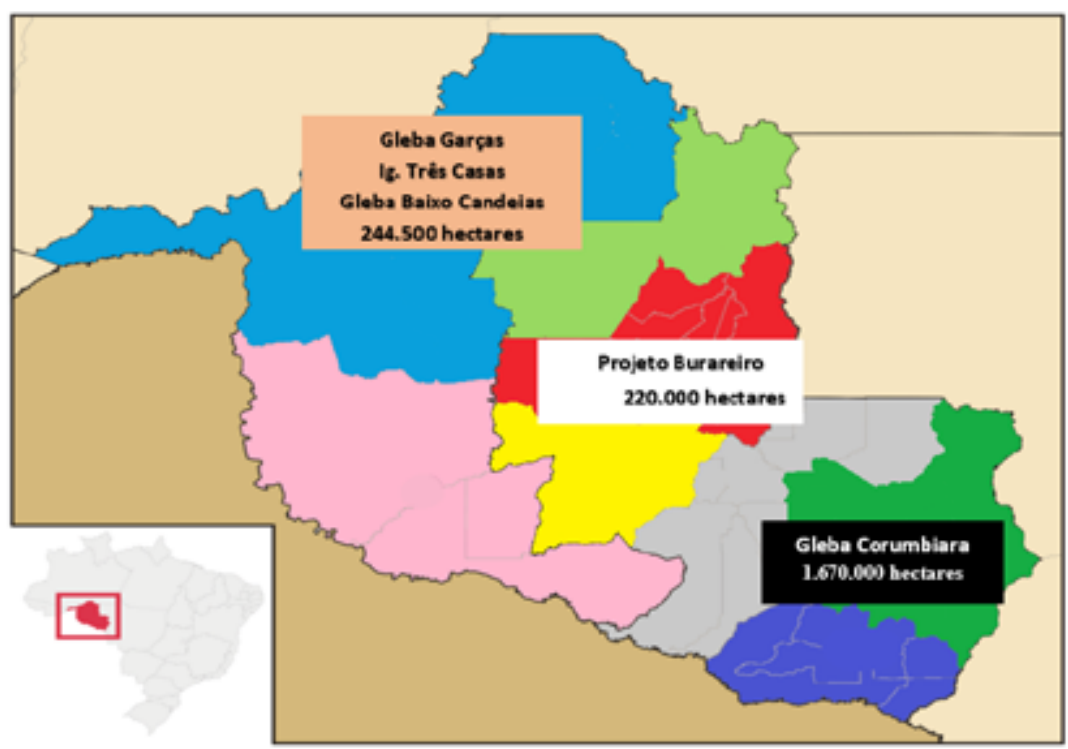

Fonte: Própria Autoria (adaptado) com base em: Perdigão, Basségio, 1992; Mesquita, 2001; Coimbra, 2015; Ferreira, 2012

Se a prioridade era para quem tinha capital (condições) de realizar derrubadas, é de perceber o caráter assimétrico na destinação das terras. Isso explica, em muito, as condições impostas para a ocorrência de inúmeros conflitos envolvendo posseiros, madeireiros, garimpeiros, especuladores, grileiros, indígenas etc. Esse panorama de desigualdade e violência perdurará até 1984. Atende-se, em grande parte, aos reais objetivos do empreendimento colonizador: favorecimento do latifúndio, reprodução e ampliação do capital financeiro internacional, direta e indiretamente expressos na exploração da madeira, extrativismo dos recursos naturais, pecuária e monocultura. É nesse quadro de exclusão explícita que se intensificarão

\footnotetext{
${ }^{1}$ As modalidades das concorrências se formalizavam nos Contratos de Alienação de Terras Públicas, principalmente. Tratava-se de institutos de domínio expedidos pelo Incra para áreas alienadas, através de licitação pública sem preferência. Vários membros de uma mesma família arrematavam um lote cada um (2.000 hectares), e assim formavam os latifúndios. O governo gastou mais demarcando os lotes do que cobrava pelas terras. Por outro lado, os fazendeiros fizeram mais dinheiro vendendo madeiras do que pagaram pelos lotes (Corumbiara, 2009).
} 
as ocupações de terras improdutivas ou públicas, em vários cantos do Estado, amplificando naquele momento a luta pela terra (Amaral, 2004).

Na região de Espigão do Oeste, em fins da década de 1960, instala-se a colonizadora Itaporanga (Irmãos Melhoranza). Tal empresa apropriou-se de 1.300.000 hectares de terras, sendo boa parte de terras indígenas, e passou a revendê-las, gerando na região mais um foco de conflito agrário (Souza, 2011). Esse conflito, marcado não só pelo enfrentamento aos processos de grilagem e violência (pistolagem), promovido pela colonizadora, também envolveu povos indígenas, ante o conhecimento público de grilagem e comércio imobiliário de terras indígenas. Quando, por intervenção dos órgãos estatais, a colonizadora é desmascarada, grande parte dos colonos que haviam sido enganados são expulsos à mão armada pelo Incra, depois de inúmeros conflitos, em 1976 (Mindlin, 2006; Nobrega, 2016).

Com semelhantes estratégias, na região entre Ariquemes e Jaru, no antigo seringal Nova Vida, outra história de massacres e resistência ocorreu. Trata-se do caso em que os Irmãos Arantes, que chegam em Rondônia no ano de 1973, utilizando-se de influências e manobras estatais, apropriam-se de uma área, inicialmente de 25 mil hectares, ampliando sua pretensão, posteriormente, para 300 mil hectares. Mais de trezentos posseiros resistiram enquanto puderam. Em 1979, ápice do confronto, são expulsos à bala, havendo inclusive mortes, entre os posseiros-ocupantes (Souza, 2011; Cruz, 2007).

Ainda na década de 1970, na Gleba Prosperidade, região de Cacoal, a soldo dos proprietários-fazendeiros paulistas Sílvio Lázaro e Moacir Ravagnani (Grupo Bonanza), um cenário de terror, violência e perseguição foi ali implantado. Em regra, as ações de repressão, ameaças e destruição eram comandadas por Antônio Domingos Sanson, ex-militar que pretendia terras, também na Gleba Prosperidade, e que gozava de trânsito livre e favores dos poderes locais, inclusive policiais. Os posseiros resistiam nas ocupações e, com apoio da Igreja católica, do Sindicato dos trabalhadores rurais e da intervenção do Advogado Agenor de Carvalho, procuraram se defender como podiam. $\mathrm{O}$ ápice desse conflito ocorreu nos anos 1978-1979 (Cruz, 2007). 
A apropriação da terra, às custas da violência e nas margens da legalidade, sobretudo na década de 1970, mobilizava, de um lado, grandes interesses nos processos de concentração e grilagem de terras. Ao mesmo tempo, há outra perspectiva para a defesa da posse da terra que reflete o sonho, mobilizado pela promessa e pela propaganda, de que a colonização resolveria os grandes problemas sociais, sobretudo dos despossuídos, marginalizados do progresso mais ao sul do país. Assim, desenha-se um cenário de intensos e variados conflitos.

Conforme Martins (1997), o avanço da frente pioneira sobre a frente de expansão potencializou a multiplicação dos conflitos entre grandes proprietários de terras e os posseiros, entre latifundiários e povos indígenas, sem mencionar os conflitos internos, entre os grupos subalternizados. Dessa forma, é possível ampliar a perspectiva e compreender que, mais que confronto entre sujeitos coletivos com interesses conflitivos, tratava-se de conflito entre "historicidades desencontradas" (Martins, 1997, p. 155).

Em publicação, no ano de 1974 (Acervo ISA, 1974), relatava-se o caso da Empresa Guaporé Agro-Industrial S/A - GAINSA. Inicialmente, a empresa "adquiriu" 275 mil hectares, na Gleba Boa Esperança (margeando a rodovia que vai de Porto Velho a Guajará-mirim), e decidiu apropriar-se de um montante de 600 mil hectares, operando assim um "verdadeiro milagre da multiplicação de terras". Walter Arantes, diretor do empreendimento, se justifica: "o que nos levou a Rondônia foi o apelo do Governo". De certa forma, essa seria sempre uma "senha autorizativa" para a grilagem de terras no Estado. Tal fato reflete, assim, à época (1973), estreitos vínculos da empresa com o governo federal. $\mathrm{Na}$ retórica de Mauro Arantes, outro sócio-diretor, o objetivo era "implantar na região a mais moderna técnica em assuntos agropecuários e agroindustriais”, com o estímulo e influência direta do então Ministro da Agricultura.

Centenas de pequenos ocupantes foram expulsos de suas posses, incluindo antigos "soldados da borracha", com títulos de ocupação expedidos pelo próprio Incra. Ainda que havendo, por parte dos pequenos posseiros, algum tipo de resistência, o processo de expulsão e perseguição dos ocupantes foi intenso. Em todas as situações, inclusive diante da oposição 
do Incra, a Justiça federal se postou ao lado da empresa Gainsa. A "farra cartorial”, em Porto Velho, amparava as pretensões da grilagem, em nome da presunção da verdade do Registro público. Fato é que a Gainsa acabou abocanhando dois milhões de hectares, em glebas esparsas pelo território. Em relatório de gestão do Incra (2011), no levantamento dos imóveis registrados no Estado, com área superior a 10 mil hectares, constam dois registros em nome da Gainsa: uma parcela desmembrada, correspondendo a 2/3 da Gleba Boa Esperança, com área de 275.022,43 hectares, e uma fração um pouco menor, também desmembrada da mesma gleba, com área de 37.100,00 hectares.

Assim, a empresa dos Irmãos Arantes, incluindo a Agropecuária "Nova Vida”, estendeu seus tentáculos proprietários por todo o Estado, sem antes se assegurar que, de alguma forma, recebesse ou encontrasse no Estado algum estímulo ou legitimação. (Acervo ISA, 1974; Cunha; Moser, 2010).

É possível, assim, constatar, à primeira vista, que as lutas no campo, dos anos de 1970, em parte foram a luta em defesa da posse. Havia elementos evidentes que mobilizavam o imaginário do colono-migrante, de que a terra era pública, que o Estado era o Incra, e que a posse, seguida do trabalho (desmatamento), lhe assegurava direitos. Em segundo lugar, tais lutas, além de tornar claros os equívocos estatais da colonização, gerenciados pelo órgão de terras, apontaram abertamente os dispositivos utilizados pelo latifúndio e pela grilagem. Se a ideia de "terra fácil” foi "vendida” pela propaganda estatal, na prática, muito mais era, para os poderosos e suas articulações governamentais. Grande parte dos que se arrogaram, ostentando títulos precários, donos de grandes áreas de terra, acabaram sendo indenizados pelo Estado, ou seja, "ninguém perdeu". E, assim, as formas de violência, de toda sorte, inclusive a estatal, foram utilizadas em vários cantos do Estado, para proteger tais pretensões. Em terceiro lugar, o fato de que, neste primeiro momento, ainda que fossem lutas desprovidas de conteúdo mais político, por vias indiretas representaram uma resistência aos projetos e programas políticos do Estado, e que em muito influenciaram as lutas futuras. 


\subsection{A DÉCADA DA DESTRUIÇÃO ${ }^{2}$ E AS LUTAS DE 1980 A 1995}

Outras lutas pela posse e permanência nas áreas, a maioria em áreas ainda não discriminadas, ocorriam por todo o Estado de Rondônia, na década de 1980. O Grupo Zorzi fundiu dois empreendimentos (Agropecuária Candeias e Madeireira Urupá), com a pretensão de se apropriar de área de 103 mil hectares, na região que envolve a Gleba Itapirema, parte do município de Urupá e parte do município de Ouro Preto do Oeste. Na região havia ocupações de vários posseiros, que aguardavam junto ao Incra a regularização de suas posses. A empresa contratou um grupo de jagunços para fazer a "limpeza" da área, mas os posseiros, pela resistência e organização espontânea, adotando táticas de represálias, conseguiram resistir e permanecer em suas ocupações (Barbosa, 2017). O auge desses acontecimentos ocorreu entre os anos de 1983 e 1984. Mesmo que o imóvel possuísse todas as configurações de área pública a ser arrecadada e destinada, após a desapropriação, o proprietário recebeu alta indenização pelo imóvel, não sem antes ter extraído enorme quantidade de madeiras.

Registra-se, também, a luta e a resistência dos posseiros na Fazenda Cabixi, entre Vilhena e Colorado do Oeste, com intenso apoio da Igreja local, em especial agentes religiosos da Igreja Evangélica de Confissão Luterana, nos anos 1981 e 1982. Nesse episódio, foram presas 34 pessoas entre lideranças, posseiros e religiosos. Entre o final da década de 1970 e início da década de 1980, há o registro da resistência dos pequenos posseiros na Fazenda São Felipe (que deu nome ao município), então município de Pimenta Bueno. Destaque-se, nesse episódio, além do protagonismo e organização dos trabalhadores que pegaram em armas para defender seus lotes, o apoio e influência do Padre João Zanotto, que foi ameaçado de ser

\footnotetext{
${ }^{2}$ Utilizou-se o conceito "A década da destruição", de Adrian Cowell e Vicente Rios, em razão de ser a melhor tradução temporal do período. Sob uma lógica interativa que reunia em um único contexto: projeto de colonização, investimentos do Banco Mundial, desmatamento intensivo e dizimação de povos indígenas, a década de 1980 representou, no Brasil e fora dele, a materialização dos equívocos irreversíveis direcionados pela política de Estado da época.
} 
enquadrado, por causa de tal apoio, em crime contra a Lei de Segurança Nacional. Conforme registro da CPT (1989), na conquista dessa área, os posseiros sofreram todo tipo de violência, expulsão e ameaças, inclusive tendo sido suas roças destruídas por desfolhantes jogados de avião, a mando dos proprietários da Fazenda Reunidas.

Adrian Cowell (2010) retratou, de forma testemunhal, a década de 1980 como a "década da destruição". Os equívocos do Projeto de colonização da Rodovia transamazônica não somente estavam se repetindo, como se amplificavam. A violência, ao grau máximo, era o retrato fiel dessa década e se efetivava não só pela destruição da natureza, como também pela extinção dos povos indígenas, repressão aos posseiros, seringueiros etc. A grilagem de terras se consolidava, exibindo os vínculos que envolviam o próprio Estado com empresas e latifundiários na dinâmica da grilagem das terras públicas. Por isso, por onde ocorreu essa violência promovida pelo latifúndio e pela grilagem, havia a marca digital do Estado.

A impunidade era a regra, mas a resistência, ainda que pontual ou espontânea, por parte dos posseiros, era constante. Assim foi na ocupação da Fazenda Pirajuí (1985) e Fazenda Dimba (1987), no município de Pimenta Bueno. De igual forma, foi o enfrentamento e resistência dos posseiros no Seringal Muqui, onde o famoso e terrível "bando do Muqui" operava, a mando do fazendeiro José Milton de Andrade Rios. Tal grupo, conforme Cruz (2007), era o alicerce do "Sindicato de Pistoleiros de Aluguel", com sede em Ji-Paraná, na década entre os anos 1970 a 1980.

O processo de constituição e estruturação do MST em Rondônia ocorreu entre os anos 1984 a 1989. Nesse período, o grupo, que articulava o Movimento no Estado, transitava entre o Departamento Rural da CUT, dos debates da CPT, e direta ou indiretamente apoiava a luta dos posseiros. Um dos marcos originários desse processo tem início com a ocupação da Fazenda Aninga, à época no município de Ouro Preto do Oeste. Foi um processo longo de ocupações, repressões e despejos (1984 a 1990). No entanto, essas primeiras mobilizações ajudaram a estruturar as bases do MST na região, onde hoje estão os assentamentos Palmares e Margarida Alves (Nova União). No ano de 1985, uma delegação de Rondônia participou do 
$1^{\circ}$ Congresso do MST, em Curitiba. E, no final de 1988, em um encontro ocorrido em Vilhena, de que participaram inclusive lideranças nacionais do movimento e organizações de apoio, como CPT e Sindicatos, é que foram oficialmente lançadas as bases de constituição do MST em Rondônia (Martins, 2009; Souza, 2011).

Das primeiras lutas, registra-se a ocupação promovida na região de Machadinho, com características ainda de pouca organização (1988), na Fazenda/Mineração “Oriente Novo", em Machadinho do Oeste. Havia ainda muito a aprender e essa ocupação acabou enfraquecida e desmobilizada principalmente por muitas perdas em razão da malária. $\mathrm{O}$ acúmulo e o aprendizado da experiência ajudaram o Movimento a se organizar. Dessa forma, se concretiza aquela que seria uma das mais simbólicas ocupações do MST, na Fazenda Seringal (1989), em Espigão do Oeste, que viria a se tornar Assentamento 25 de julho. Nos anos seguintes, um processo intenso de mobilização e ocupações (Parecis, 1992; Ouro Preto e Nova União, 1995) resultaram, ao final, na criação de três Projetos de Assentamento, consolidando, naquela região (Ouro Preto do Oeste e municípios vizinhos), a base central do MST no Estado: Assentamento Zumbi, 1996, Assentamento Palmares, 1996 e Assentamento Margarida Alves, 1997, beneficiando cerca de 700 famílias assentadas (Monteiro, 2004; Martins, 2009; Souza, 2011).

No processo de estrutura e fortalecimento, o MST também se fará presente no apoio à luta pela terra no Cone Sul do Estado, sobretudo na região de Corumbiara, característica por fazer parte de uma região-polo de grandes concessões públicas de terra e do berço do agronegócio no Estado. Nessa região, as primeiras lutas contaram com uma forma de organização pontual, espontânea, por parte dos trabalhadores, e ainda com forte apoio da Igreja e do movimento sindical. Sob forte repressão, a resistência custava caro aos grupos que, além de despejos, também enfrentavam a violência física por parte da repressão privada e contratada, por meio de bandos armados. (Martins, 2009). Nesses casos, como nas demais regiões, a atuação do Estado sempre amparava as pretensões do latifúndio. No entanto, do conflito ocorrido, da ocupação Vitória da União (1979-1981), nasceu o assentamento no ano de 1986. Na ocupação 
da fazenda Verde Seringal/Fazenda Guarajus (1980-1983), o assentamento foi criado em 1988, e na Fazenda Adriana (1990-1993), onde já se fazia presente o apoio das lideranças do MST, o assentamento, pela via da desapropriação do imóvel, foi criado em 1993. Ao todo, nessas três áreas de luta e resistência, no cone sul do Estado, conforme Martins (2009), mais de 800 famílias foram beneficiadas. O MST, a CPT e os Sindicatos de trabalhadores rurais da região fizeram da ocupação e resistência da Fazenda Adriana um marco de organização fundamental, que serviria de inspiração e motivação para, pouco mais tarde, a Ocupação de Santa Elina, onde ocorreu o "Massacre de Corumbiara", em 1995.

Muitas vezes, a "forma-ocupação" assumia também uma dimensão instrumental, na política de negociação. Foi através da ocupação Lambari (MST), no município de Espigão do Oeste, no ano de 1990, em meio a ameaças e pressões organizadas, que se conseguiu, negociadamente, a ocupação de outro imóvel, em Ariquemes (Assentamento Migrantes), onde as famílias foram assentadas (Fernandes, 1999).

A expansão territorial das ações coletivas do MST, em meados da década de 1980 em diante, confirmava o fim, e em grande parte os equívocos, dos Projetos de Colonização Dirigida implementados pelo Incra de 1970-1984. Sinaliza também o "fim do encanto" com a terra prometida, uma vez, que vai ficando cada vez mais distante, para as famílias dos colonos-migrantes, a expectativa de obterem seus lotes. Esse, na verdade, era o cenário da luta dos camponeses por toda a região amazônica. Explica-se, portanto, no primeiro momento, a tática de apoio pontual à luta existente, protagonizada pelos posseiros, seja pela articulação pastoral da Igreja, seja por setores embrionários dos movimentos. (Souza, 2011).

A ocupação da fazenda Santa Elina, em 1995, há que ser tomada como um marco histórico referencial, também para os movimentos sociais do campo, em Rondônia. Já exaustivamente analisado, sob muitos enfoques, o acontecimento do "Massacre de Corumbiara", ocorrido em 9 de agosto de 1995, sinalizou, pela primeira vez, a divergência de pensamento e estratégias de atuação em relação à luta pela terra. Conforme Martins (2009), o desentendimento sobre a viabilidade da ocupação, 
enquanto estratégia, afastou tanto o apoio do MST quanto da CPT, em relação à ocupação. No entanto, o acontecimento "Santa Elina”, daquele agosto de 1995, forjou, na consciência nacional, uma outra sensibilidade em relação à questão agrária. Igualmente mobilizou a opinião internacional, desnudando o contexto de contradições políticas, assim como a ação refinada do patrocínio da violência pelo poder do latifúndio. No caso, não se trata apenas de nomes, como o de Hélio Pereira de Moraes, beneficiado pela transferência pela União de 20 mil hectares de terra, ou de Antenor Duarte, que conjuntamente idealizou e subsidiou a ação da pistolagem, onde jagunços e militares agiram conjuntamente. A ação arquitetada do massacre contou com amplo e logístico apoio do governo do Estado da época (Valdir Raupp), e suas Secretarias operacionais (Martins, 2009).

A Tabela 3, sem a pretensão de totalizar os processos de luta dos movimentos sociais do campo, busca elencar os principais conflitos ocorridos no período de 1970 a 1995 . Toma-se o recorte do ano em que ocorre o "massacre de Corumbiara", pelo fato de que esse trágico acontecimento representou, de forma prática e simbólica, um "despertar do debate agrário", no cenário nacional. Não ignorando outras formas de enfrentamento, sobretudo na violência sofrida pelos povos indígenas, a opção pelos conflitos no campo, no seio dos projetos de colonização, destina-se, a por em evidência as próprias contradições de tal projeto.

Três formas principais de organização/resistência caracterizavam as lutas por terra na década de 1970 e 1980: a ocupação "espontânea", a ocupação controlada e a ocupação organizada (CPT/RO, 1991). A ocupação "espontânea" consistia de pequenos grupos que, sem conhecer as implicações e consequências da luta, enfrentavam as dificuldades. Em geral, muitas dessas ocupações acabavam sendo expulsas sem qualquer forma de resistência. Ocupação controlada eram as ocupações em que a coordenação estava, em regra, centralizada em uma das lideranças, sendo que esta era dirigida por alguém de fora, que poderia ser um parlamentar ou parlamentares que acabavam interferindo no movimento para fins eleitoreiros. Por fim, a ocupação organizada contava com uma coordenação assumida pelos próprios posseiros, com o apoio de um ou outro sindicato combativo e da Igreja. 
Em parte, concorda-se com tal distinção, defendendo porém uma classificação mais ampliada do fenômeno, em termos de "mobilização autônoma ou espontânea", que seriam grupos organizados para fins pontuais, localizados; "mobilização organizada", quando a mobilização detinha um componente político, com uma coordenação e com fins mais ampliados.

Em relação aos processos de resistência em si, concorda-se com Bernardo Mançano (1999), ao referir-se ao duplo processo de espacialização (inserir-se, registrar-se no espaço) e na territorialização (socialização política) das lutas agrárias. Dessa forma, pelas ações concretas, por meio de ocupações, manifestações e mobilizações, se inscreve, no espaço, o processo. E, pela territorialização, tendo a ocupação como condição, se trava a luta política, simbólica, quando a luta é politizada.

Tabela 3 - Territorialização das resistências em Rondônia (1970-1995)

\begin{tabular}{|c|l|l|l|c|}
\hline \multicolumn{5}{|c|}{ Luta pela terra em Rondônia (Anos 1970-1995) } \\
\hline $\mathbf{1}$ & \multicolumn{1}{|c|}{ Local } & \multicolumn{1}{|c|}{ Imóvel/Empresa } & \multicolumn{1}{c|}{$\begin{array}{c}\text { Formas de } \\
\text { resistência } \\
\text { do Oeste }\end{array}$} & Período \\
\hline $\mathbf{2}$ & Espigão do Oeste & $\begin{array}{l}\text { Itaporanga } \\
\text { Colonizadora } \\
\text { (Grupo Melhoranza) }\end{array}$ & Ocupação/posse & $1966-1976$ \\
\hline $\mathbf{3}$ & Ji-Paraná & Posseiros Rio Urupá & Posse & 1978 \\
\hline $\mathbf{4}$ & $\begin{array}{l}\text { Espigão do Oeste e } \\
\text { Cacoal }\end{array}$ & $\begin{array}{l}\text { Projetos de } \\
\text { Colonização/ } \\
\text { Madeireiras }\end{array}$ & $\begin{array}{l}\text { Território } \\
\text { indígena } \\
\text { (Suruís) }\end{array}$ & $1970-1989$ \\
\hline $\mathbf{5}$ & Presidente Médici & $\begin{array}{l}\text { Seringal Muqui (José } \\
\text { Milton de Andrade } \\
\text { Rios) }\end{array}$ & Posse & $1970-1980$ \\
\hline $\mathbf{6}$ & Ariquemes & $\begin{array}{l}\text { Fazenda Nova Vida } \\
\text { (Irmãos Arantes) }\end{array}$ & Posse & $1973-1979$ \\
\hline $\mathbf{7}$ & Porto Velho & $\begin{array}{l}\text { Guaporé Agro- } \\
\text { Indústria S.A } \\
\text { (Gainsa) }\end{array}$ & Posse & $1973-1980$ \\
\hline
\end{tabular}




\begin{tabular}{|c|c|c|c|c|}
\hline \multicolumn{5}{|c|}{ Luta pela terra em Rondônia (Anos 1970 - 1995) } \\
\hline & Local & Imóvel/Empresa & $\begin{array}{l}\text { Formas de } \\
\text { resistência }\end{array}$ & Período \\
\hline 8 & BR 429 (abertura) & $\begin{array}{l}\text { Projetos de } \\
\text { Colonização }\end{array}$ & $\begin{array}{l}\text { Território } \\
\text { Indígena } \\
\text { (Uru-eu-wau- } \\
\text { wau) }\end{array}$ & $\begin{array}{l}1974 \mathrm{em} \\
\text { diante }\end{array}$ \\
\hline 9 & Jaru & $\begin{array}{l}\text { Seringalistas/ } \\
\text { Seringueiros }\end{array}$ & $\begin{array}{l}\text { Território } \\
\text { Indígena } \\
\text { (Uru-eu-wau- } \\
\text { wau) } \\
\end{array}$ & 1974 \\
\hline 10 & $\begin{array}{l}\text { Presidente Médici/ } \\
\text { Castanheiras }\end{array}$ & $\begin{array}{l}\text { Igarapé Grande } \\
\text { (Fernando Iberê x } \\
\text { Posseiros) }\end{array}$ & Ocupação/Posse & 1976 \\
\hline 11 & Rolim de Moura & Fazenda Reunidas & Posse & $1976-1986$ \\
\hline 12 & $\begin{array}{l}\text { Pimenta Bueno/ } \\
\text { São Felipe }\end{array}$ & Fazenda São Felipe & Ocupação/posse & $1977-1988$ \\
\hline 13 & $\begin{array}{l}\text { Cacoal/Rolim de } \\
\text { Moura }\end{array}$ & $\begin{array}{l}\text { Gleba Prosperidade } \\
\text { (Grupo Bonanza) }\end{array}$ & Ocupação/posse & $1978-1979$ \\
\hline 14 & Colorado do Oeste & $\begin{array}{l}\text { Fazenda Verde } \\
\text { Seringal }\end{array}$ & Ocupação & $1978-1983$ \\
\hline 15 & Pimenta Bueno & Abaitará & Ocupação/posse & 1978 \\
\hline 16 & $\begin{array}{l}\text { Ouro Preto do } \\
\text { Oeste }\end{array}$ & $\begin{array}{l}\text { Comissão Pastoral da } \\
\text { Terra } \\
\text { (camponeses) }\end{array}$ & $\begin{array}{l}\text { Organização/ } \\
\text { Movimento }\end{array}$ & 1979 \\
\hline 17 & Colorado do Oeste & $\begin{array}{l}\text { Fazenda Guajarus/ } \\
\text { Vitória da União }\end{array}$ & Ocupação & $1979-1981$ \\
\hline 18 & Ariquemes & $\begin{array}{l}\text { Seringalistas/ } \\
\text { Garimpeiros/ } \\
\text { Seringueiros }\end{array}$ & \begin{tabular}{|l|} 
Território \\
Indígena \\
(Uru-eu-wau- \\
wau) \\
\end{tabular} & 1979 \\
\hline 19 & Colorado do Oeste & Fazenda Cabixi & Ocupação/posse & $1981-1982$ \\
\hline 20 & Monte Negro & $\begin{array}{l}\text { Igarapé Nova } \\
\text { Floresta/Garimpeiros } \\
\text { clandestinos }\end{array}$ & $\begin{array}{l}\text { Território } \\
\text { Indígena } \\
\text { (Uru-eu-wau- } \\
\text { wau) }\end{array}$ & 1982 \\
\hline
\end{tabular}




\begin{tabular}{|c|c|c|c|c|}
\hline \multicolumn{5}{|c|}{ Luta pela terra em Rondônia (Anos 1970 - 1995) } \\
\hline & Local & Imóvel/Empresa & $\begin{array}{l}\text { Formas de } \\
\text { resistência }\end{array}$ & Período \\
\hline 21 & Ariquemes & $\begin{array}{l}\text { Projetos de } \\
\text { Colonização/Garimpo }\end{array}$ & \begin{tabular}{|l} 
Território \\
Indígena \\
(Uru-eu-wau- \\
wau) \\
\end{tabular} & $\begin{array}{l}\text { Década de } \\
1980\end{array}$ \\
\hline 22 & $\begin{array}{l}\text { Alvorada do Oeste, } \\
\text { São Miguel, Urupá }\end{array}$ & $\begin{array}{l}\text { Projetos de } \\
\text { Colonização/Garimpo }\end{array}$ & $\begin{array}{l}\text { Território } \\
\text { Indígena } \\
\text { (Uru-eu-wau- } \\
\text { wau) }\end{array}$ & $\begin{array}{l}\text { Década de } \\
1980\end{array}$ \\
\hline 23 & Urupá/Ji-Paraná & \begin{tabular}{|l} 
Agropecuária \\
Candeias/Madeireira \\
Urupá (Grupo Zorzi) \\
\end{tabular} & Ocupação/posse & $1983-1984$ \\
\hline 24 & Chupinguaia & T.I Rio Omerê & \begin{tabular}{|l|} 
Território \\
Indígena \\
(Akunsu- \\
Canoé) \\
\end{tabular} & $1980-1985$ \\
\hline 25 & Pimenta Bueno & Fazenda Camapuã & Ocupação/posse & $1983-1984$ \\
\hline 26 & Ji-Paraná & $\begin{array}{l}\text { Projetos de } \\
\text { Colonização }\end{array}$ & $\begin{array}{l}\text { Território } \\
\text { Indígena } \\
\text { (Povos Gavião e } \\
\text { Arara) } \\
\end{array}$ & $1983-1986$ \\
\hline 27 & Ji-Paraná & $\begin{array}{l}\text { Articulação/Aliança } \\
\text { Indígena } \\
\text { (Gavião, Arara, Zoró, } \\
\text { Cinta-Larga e Suruí) }\end{array}$ & $\begin{array}{l}\text { Organização/ } \\
\text { Movimento }\end{array}$ & 1984 \\
\hline 28 & \begin{tabular}{|l|} 
Ouro Preto do \\
Oeste/Nova União \\
\end{tabular} & \begin{tabular}{|l} 
Fazenda Aninga/ \\
Firasa
\end{tabular} & Ocupação & $1984-1990$ \\
\hline 29 & Cacoal & $\begin{array}{l}\text { 1a Assembleia Geral } \\
\text { dos Povos Indígenas/ } \\
\text { União das Nações } \\
\text { Indígenas (Suruí, Cinta } \\
\text { Larga, Oro-Wari, } \\
\text { Gavião e Mequéns }\end{array}$ & $\begin{array}{l}\text { Organização/ } \\
\text { Movimento }\end{array}$ & 1985 \\
\hline 30 & Pimenta Bueno & Fazenda Pirajuí & Ocupação & 1985 \\
\hline 31 & Ariquemes & $\begin{array}{l}1^{\circ} \text { Encontro Nacional } \\
\text { de Seringueiros } \\
\text { (Rondônia, Amazonas } \\
\text { e Acre) }\end{array}$ & $\begin{array}{l}\text { Organização/ } \\
\text { Movimento }\end{array}$ & 1985 \\
\hline
\end{tabular}




\begin{tabular}{|c|c|c|c|c|}
\hline \multicolumn{5}{|c|}{ Luta pela terra em Rondônia (Anos 1970 - 1995) } \\
\hline & Local & Imóvel/Empresa & $\begin{array}{l}\text { Formas de } \\
\text { resistência }\end{array}$ & Período \\
\hline 32 & \begin{tabular}{|l|}
$\begin{array}{l}\text { Seringueiras (Bom } \\
\text { Princípio) }\end{array}$ \\
\end{tabular} & $\begin{array}{l}\text { Projeto Primavera/ } \\
\text { Fazendeiros }\end{array}$ & Ocupação & 1985 \\
\hline 33 & Pimenta Bueno & Fazenda Dimba & Ocupação & 1987 \\
\hline 34 & Costa Marques & $\begin{array}{l}\text { Santa Fé } \\
\text { (Pascoal Novaes x } \\
\text { Posseiros) }\end{array}$ & Posse & 1987 \\
\hline 35 & Costa Marques & Madeireiras & $\begin{array}{l}\text { Território } \\
\text { Indígena } \\
\text { (Uru-eu-wau- } \\
\text { wau) }\end{array}$ & 1987 \\
\hline 36 & Jaru & \begin{tabular}{|l|} 
Fazenda Belo \\
Horizonte \\
\end{tabular} & Ocupação/Posse & 1987 \\
\hline 37 & Ji-Paraná & $\begin{array}{l}1^{\text {a }} \text { Romaria da Terra } \\
\text { (tema: migração) }\end{array}$ & $\begin{array}{l}\text { Organização/ } \\
\text { Movimento }\end{array}$ & 1987 \\
\hline 38 & Alto Paraíso & $\begin{array}{l}\text { Mineração Bom } \\
\text { Futuro }\end{array}$ & Posse & 1987 \\
\hline 39 & $\begin{array}{l}\text { Machadinho do } \\
\text { Oeste }\end{array}$ & $\begin{array}{l}\text { Mineração Oriente } \\
\text { Novo }\end{array}$ & Ocupação & 1988 \\
\hline 40 & Vilhena & $\begin{array}{l}\text { Fundação do MST/ } \\
\text { RO }\end{array}$ & $\begin{array}{l}\text { Organização/ } \\
\text { Movimento }\end{array}$ & 1988 \\
\hline 41 & Costa Marques & $\begin{array}{l}1^{\circ} \text { Encontro dos } \\
\text { Povos da Floresta } \\
\text { (Seringueiros, } \\
\text { Extrativistas e } \\
\text { Ribeirinhos) } \\
\end{array}$ & $\begin{array}{l}\text { Organização/ } \\
\text { Movimento }\end{array}$ & 1989 \\
\hline 42 & Espigão do Oeste & Fazenda Seringal & Ocupação & 1989 \\
\hline 43 & Ji-Paraná & $\begin{array}{l}\text { Articulação Central } \\
\text { das Associações } \\
\text { Rurais de Ajuda } \\
\text { Mútua - ACARAM } \\
\text { (fundação) } \\
\end{array}$ & $\begin{array}{l}\text { Organização/ } \\
\text { Movimento }\end{array}$ & 1989 \\
\hline 44 & Ji-Paraná & 2a Romaria da Terra & $\begin{array}{l}\text { Organização/ } \\
\text { Movimento }\end{array}$ & 1989 \\
\hline 45 & Espigão do Oeste & Fazenda Lambari & Ocupação & 1990 \\
\hline 46 & $\begin{array}{l}\text { Colorado do } \\
\text { Oeste/Corumbiara }\end{array}$ & Fazenda Adriana & Ocupação & 1990 \\
\hline
\end{tabular}




\begin{tabular}{|c|c|c|c|c|}
\hline \multicolumn{5}{|c|}{ Luta pela terra em Rondônia (Anos 1970 - 1995) } \\
\hline & Local & Imóvel/Empresa & $\begin{array}{l}\text { Formas de } \\
\text { resistência }\end{array}$ & Período \\
\hline 47 & $\begin{array}{l}\text { Alta Floresta do } \\
\text { Oeste }\end{array}$ & $\begin{array}{l}\text { Área Indígena } \\
\text { Mequéns x posseiros }\end{array}$ & $\begin{array}{l}\text { Território } \\
\text { Indígena } \\
\text { (Povo Mequéns) }\end{array}$ & 1990 \\
\hline 48 & Ji-Paraná & $\begin{array}{l}\text { Assembleia dos } \\
\text { Povos Indígenas de } \\
\text { Rondônia e Mato } \\
\text { Grosso (várias etnias) }\end{array}$ & $\begin{array}{l}\text { Organização/ } \\
\text { Movimento }\end{array}$ & 1991 \\
\hline 49 & Ji-Paraná & $\begin{array}{l}\text { Movimento dos } \\
\text { Atingidos por } \\
\text { Barragens em } \\
\text { Rondônia - MABRO } \\
\text { (Camponeses, } \\
\text { indígenas, Sindicatos) } \\
\end{array}$ & $\begin{array}{l}\text { Organização/ } \\
\text { Movimento }\end{array}$ & 1991 \\
\hline 50 & Ariquemes & Fazenda Shangrilá & Ocupação & 1992 \\
\hline 51 & Ji-Paraná & $\begin{array}{l}\text { Ato Anti-Barragens } \\
\text { (diversas organizações } \\
\text { camponesas, pastorais } \\
\text { e indígenas) } \\
\end{array}$ & $\begin{array}{l}\text { Movimento / } \\
\text { Organização }\end{array}$ & 1993 \\
\hline 52 & Ji-Paraná & $\begin{array}{l}\text { Federação dos } \\
\text { Trabalhadores } \\
\text { na Agricultura } \\
\text { de Rondônia } \\
\text { - FETAGRO } \\
\text { (fundação) } \\
\end{array}$ & $\begin{array}{l}\text { Organização/ } \\
\text { Movimento }\end{array}$ & 1993 \\
\hline 53 & $\begin{array}{l}\text { Ouro Preto do } \\
\text { Oeste }\end{array}$ & Fazenda Triângulo & Ocupação & 1995 \\
\hline 54 & Corumbiara & Fazenda Santa Elina & Ocupação & 1995 \\
\hline
\end{tabular}

Fonte: Própria Autoria com base em: Cruz, 2007; Souza, 2011; Felzke, 2014; Cunha; Moser, 2010; Martins, 2009; Perdigão; Bassegio, 1992; Nobrega, 2016; Arquivos CPT/RO. 


\subsection{OS PROCESSOS DE RESISTÊNCIA E A AÇÃO ARTICULADA}

Dentro da mesma dinâmica que caracterizou aquilo que José de Souza Martins retrata como avanço da frente pioneira sobre a frente de expansão (Martins, 1997), o caso de Rondônia, a um só tempo, delineia uma dupla situação de enfrentamento e conflito. De um lado, na mesma lógica colonizadora, o conflito entre grandes latifundiários e grileiros e pequenos colonos e posseiros; de outro, entre esses grandes proprietários, madeireiros, grileiros e os povos e comunidades originárias, tradicionais.

Em grande escala, o projeto do Estado objetivava, no destino, o estímulo à empresa rural e a grande propriedade. $\mathrm{O}$ pequeno colono seria oportunamente incorporado, e o colono-migrante, que se aventurou em busca de seu sonho, ainda que fosse um desvio de rota, poderia ser, posteriormente, incorporado. De qualquer forma, medidas foram tomadas para conter as migrações, e o Estado judicial e policial foi ativado para manter imunes as grandes pretensões proprietárias ${ }^{3}$. A luta dos povos originários, sobretudo indígenas, foi por muitos meios silenciada. Se alguma repercussão teve, foi muito mais pelas barbaridades do extermínio e pela repercussão de agentes internacionais.

Anota-se, então, que a dinâmica compreendida como "territorialização das lutas" refere-se, para fins de análise, mais aos fenômenos ocorridos na frente pioneira, ou seja, no bojo dos processos e projetos de colonização. Representa, assim, tal contexto, o tempo da transformação da terra, na lógica tanto estatal quanto mercadológica, ou seja, vinculada aos modos de produção e relações capitalistas. Impõe-se, nessa dinâmica, a construção e organização do espaço social nos moldes negociais. Para tanto, a terra se

\footnotetext{
${ }^{3}$ Entre essas medidas, destaca-se a contrapropaganda patrocinada pelo Governo, a partir da segunda metade da década de 1970, buscando demonstrar o caos cotidiano dos migrantes em Rondônia, o que revelava um verdadeiro paradoxo. Além disso, medidas governamentais foram tomadas no sentido de "fechar fronteiras", inclusive por meio de decreto-lei federal, autorizando o Departamento Nacional de Estradas e Rodagem a barrar entrada de migrantes ilegais em direção a Rondônia. Para maior aprofundamento, consultar Nóbrega (2016).
} 
torna negócio/mercadoria, legitimada em regra pelo estatuto da propriedade privada e seus determinantes (Silva, 2015).

Dessa forma, as lutas retratadas no item anterior, ainda que exponham esses desencontros históricos, refletem um processo de resistência e enfrentamento que ajudou a moldar a consciência política nos anos posteriores. Foram esses enfrentamentos que contribuíram para gestar as bases possíveis para uma melhor organização e consciência de classe, bem como para forjar, pela própria autocrítica, a consciência da necessidade de uma luta mais ampliada, no horizonte futuro. É nessa dinâmica que começam a se articular os processos de apoio e alianças, assim como a criar bases para que essas articulações pudessem atuar de forma mais qualificada, em outros ambientes ou espaços de participação.

Dessa maneira, outros atores comparecem nesse cenário, seja em forma protagônica, seja no apoio e nas mediações. O papel da Igreja foi fundamental nesse momento, uma vez que representava, no contexto, não apenas como um fator de agregação, mas também por envolvimento direto em parceria com as lideranças. Tal atuação, inclusive, projetava uma maior visibilidade ao que acontecia no meio rural: os processos de resistência e os dramas sofridos pelos migrantes, colonos, posseiros e povos indígenas.

Com tal percepção, passou-se a considerar não somente a ação prática e a mobilização como instrumentos, mas também o processo de formação e capacitação, pelo conhecimento dos próprios direitos e pela qualificação, em relação às ferramentas de denúncia e atuação junto aos órgãos públicos.

Em regra, esse trabalho de acompanhamento, assessoria e articulação, no caso de Rondônia, sempre foi assumido pela Comissão Pastoral da Terra, que é formada no Estado, no ano de 1979, na cidade de Ouro Preto do Oeste, pelo Pe. José Simionatto, Ir. Augusta, Ir. Antonieta e várias lideranças das Comunidades de Base. Na esfera institucional, a CPT foi sempre estimulada e apoiada pelos bispos das três dioceses do Estado, mas sobretudo por Dom Antônio Possamai, que esteve à frente da Diocese de Ji-Paraná, entre os anos de 1983 a 2007. Entre outras atuações da CPT, na segunda metade da década de 1980, destaca-se a denúncia insistente do 
trabalho escravo em vários municípios da região, sobretudo no cone sul do Estado (CPT/RO, 1989).

Revisitando a genealogia das organizações e movimentos sociais do campo, em Rondônia, plausível reconhecer que, no primeiro momento, a luta pela posse da terra teve muito forte esse ethos camponês ${ }^{4}$ de enfrentamento ao latifúndio. Isso se dava pela resistência estruturada em torno do núcleo familiar, contra os empreendimentos rurais (empresas), que simbolizavam naquele momento a expulsão, a miséria e a destruição do sonho.

Já naquela época, algumas análises apontavam para uma realidade que mais tarde viria a ocorrer como fenômeno no campo: a questão da pecuarização x agricultura camponesa. Martins (1980) acentuava que uma "vaca amazônica" significava a expulsão de uma família inteira de posseiros, uma vez que ela ocupa a mesma área que esse posseiro precisaria em um ano para prover o sustento da família e inserir o excedente no mercado. Dessa forma, a expulsão dos colonos, ou posteriormente a inversão da agricultura para a pecuária, incidiria na expulsão dos posseiros, desemprego, precarização das suas condições de vida (Martins, 1980, p. 24).

Objetiva-se o esforço dessa investigação, portanto, por ser uma tentativa de homogeneizar discursivamente as contradições históricas, muitas vezes permeadas por lacunas e silêncios. Assim, à evidência, é preciso insistir que Rondônia não é uma terra sem passado, muito menos não se pode ignorar processos de luta e resistências, como se parecessem não existir ou existindo apenas no silêncio. E, portanto, a ruptura contra o

\footnotetext{
${ }^{4}$ Conforme Murta (2014), o ethos camponês manifesta-se em um conjunto de valores externados nos elementos terra, família e trabalho. A categoria terra é compreendida como espaço social da família e não mero bem ou mercadoria. $O$ trabalho expressa a integração da força familiar e sua potencialidade transformadora. Vincula-se ao sustento da família. E a família, para além de ser uma unidade de produção, manifesta-se como núcleo aglutinador, a base orgânica e social camponesa. Todas essas categorias se entrecruzam. João Carlos Tedesco (1998) indica que é a propriedade da terra e a autonomia do trabalho os elementos fundamentais da constituição desse ethos camponês, que também chama de ethos colono. A representação como camponês simboliza também uma marca de resistência identitária, que legitima esse camponês no momento em que se vê efetivada sua subordinação ao modo de produção do capitalismo. A natureza desse ethos camponês, enfim, firma-se nas relações familiares e na convivência (sociabilidade), de forma dinâmica e (re)construtiva, não sem tensão, em relação ao passado e aos processos com relação à sociedade que o engloba. Para maior aprofundamento sobre o debate, inclusive sobre a noção de "diferenciação social camponesa", ver Ricardo Abramovay (2007).
} 
"silêncio das genealogias" é também a insurgência contra o "silêncio dos vencedores" (OLIVEIRA, 2000). Em outras palavras, a memória ${ }^{5}$ revolvida, no chão do esquecimento, é condição de análise essencial, sobretudo contra os processos de colonialismos perpetuados, que alimentam e estruturam a identidade dos segmentos dominantes. Nesse campo, a identificação dessas lutas ajuda a decifrar os processos contemporâneos de enfrentamento, resistência e mobilização.

À luz desses requisitos, compreende-se que a ideia de territorialização das lutas camponesas, no contexto, revela importantes significados. Primeiramente, expõe as contradições e ambiguidades das políticas estatais e governamentais. Em segundo lugar, revela, no plano circunstancial e no acúmulo das ações, o enfrentamento das ações do capitalismo no campo, seja pela apropriação indébita de terras públicas (grilagem), seja pelo modo de produção capitalista: agronegócio e monocultivo. Em terceiro lugar, a territorialização das lutas camponesas traduz a afirmação concreta e simbólica do anseio da democratização da terra e do trabalho, elevando tal situação ao patamar de um direito social a ser conquistado.

\footnotetext{
${ }^{5}$ A ideia de memória, como instrumental de abordagem e compreensão dos fenômenos humanos, aqui se ampara em importantes autores contemporâneos que utilizam distintas categorias como "camadas" de memória, memórias subterrâneas, memória como produto social e investigação da memória não como versão, mas como narrativa. Para maiores aprofundamentos sobre essa forma de abordagem, ver: Elcléa Bosi (2003), Alessandro Portelli (2016) e Verena Alberti (2004).
} 
Figura 2 - A territorialização das lutas de resistência dos anos 1970-2000

\section{Territorialização em Rondônia}

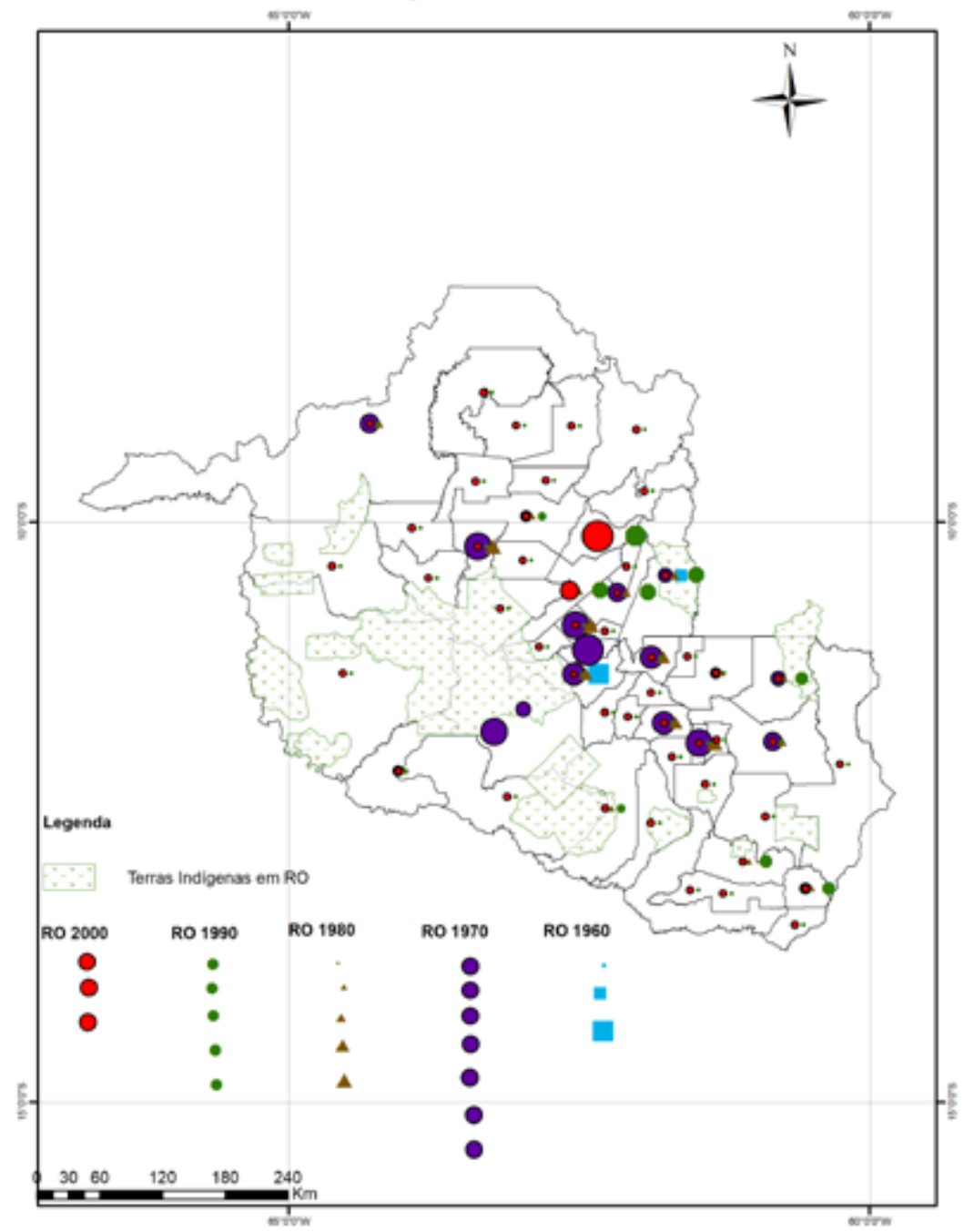

Ricardo Gilson da Costa (adaptado) com base em: Cruz, 2007; Souza, 2011; Felzke, 2014; Cunha; Moser, 2010; Martins, 2009

Conforme a Figura 2, os conflitos dos anos 1970 e 1980 seguiram territorialmente o itinerário dos Projetos de colonização, expondo suas lacunas e equívocos. Devido ao intenso movimento migratório estimulado à época pela propaganda oficial, os grupos, organizados ou semiorganizados, entendiam que bastaria ao Estado destinar as terras arrecadadas, uma vez que eram 
públicas. Assim, a estratégia da ocupação e resistência na posse vinculava inclusive a própria lógica de colonização objetivada pelo Estado. No entanto, pela adoção da prática de "reserva de terras" a grupos de conveniência, os conflitos se tornaram iminentes. Em maior evidência, os conflitos ocorriam na região centro sul do Estado (Ji-Paraná e região da bacia do Rio Machado), e no coração da experiência colonizadora, ou seja, na região central, onde tinha sido implantado o primeiro Projeto (PIC Ouro Preto), em 1970.

Assim vai se compondo, no cenário, uma série de atores no processo de colonização, gestado no Território de Rondônia, nas décadas de 1970-1980. Coexiste nessa realidade, portanto, os colonos tradicionais, atraídos pela primeira propaganda oficial, os colonos que haviam sido atraídos pela especulação imobiliária da Colonização privada, e a imensa leva de migrantes-colonos que, em um segundo momento, ainda pela propaganda e pelo "boato", dirigiam-se a Rondônia, em busca de realização do sonho da terra. Em tudo isso, agindo, permissionando ou se omitindo, o Estado constrói e reproduz a lógica da colonização, na moldura anteriormente planejada, uma vez que reúne poder (intencionalidade) e condições objetivas para tanto.

Hebétte (2004), ao analisar o papel desse sujeito institucional na colonização, o Incra, dirá que tal órgão funciona como o Estado dentro do Estado. A função de selecionar, demarcar e abrir estradas, além de propiciar assistência (saúde, educação, comercialização), era do Incra, pelo menos em teoria. $\mathrm{Na}$ prática, a história era outra. Ainda que a intensa mobilidade migratória fosse argumentada como justificação para a inefetividade do órgão, não subsiste o argumento, sobretudo em vista dos vultosos repasses, mobilizados pelo Programa do Banco Mundial POLONORESTE (Souza, 2006).

A geopolítica da colonização de Rondônia firmava-se na materialidade estrutural daquilo que o Estado considerava estratégico: continuidade à frente de expansão e pioneira, para além do Mato Grosso. Implementou-se, para tanto, a construção da Rodovia (BR 364), e reservou grande contingente de áreas públicas a serem arrecadas pelo Estado (COY, 1986). No entanto, além dessas condições materiais, o que funda- 
mentaria o empreendimento dirigido ou tolerado pelo Estado é fundado em outra lógica: instrumentalizar, pelo processo de colonização, as condições de implementação da empresa rural. Para tal, serão criadas ou manejadas as condições possíveis para a estruturação do capitalismo numa região de fronteira, que poderia ser, portanto, a fronteira do agronegócio. Dessa forma, de 1970 a 1984, em definitivo, a colonização foi a contrarreforma-agrária. Ao mesmo tempo que contribuía para "despolitizar" a questão agrária, candente no sul do país, viabilizava-se o latifúndio, sem traumas e sem dor (Santos, 1993).

Pelos diversos enfrentamentos e formas de resistência, seja na luta dos camponeses, seja nas formas mais organizadas dos movimentos sociais do campo, a questão agrária, assim como seu forte apelo de transformação social, assume um caráter político. Ainda que inserida na pauta desenvolvimentista da "modernização conservadora"6 do ruralismo patronal, as lutas por reforma agrária na Amazônia desmentiram o "Estatuto da terra" e seus intérpretes. A aniquilação da reforma agrária pelos projetos de colonização ressuscitava a velha lógica do latifúndio, de reformar para que tudo permaneça como sempre foi, ou de modernizar a retórica num reacionarismo prático, para que a dinâmica patrimonialista persista.

No caso de Rondônia, a expansão do agronegócio, pela via da pecuarização e do monocultivo da soja, ganha cada vez maior contorno. As estratégias econômicas, como também a gestão estatal, atualmente, operam as políticas públicas, que reeditam a reprimarização econômica, pela objetivação da matéria prima à disposição: boi e soja. E assim, sob tal lógica, monopoliza-se ou reordena-se o território, ao passo que se avultam as contradições desse modelo, sobretudo pelos conflitos socioterritoriais ou agrários (Silva, 2015). Paradoxal que políticas e subsídios de proteção à

\footnotetext{
${ }^{6}$ Dois autores são tomados aqui como referência para aplicar o conceito à questão da colonização amazônica: Guimarães (1977) e Azevêdo (1982). A lógica da modernização conservadora, no caso da reforma agrária, anula seu sentido, uma vez que o objetivo é a produção da agropecuária e da renovação tecnológica, sem alterar a estrutura agrária no país. Por outro lado, a "modernização conservadora" sinaliza também para o interior do Estado, sendo que é lá que se vinculam os compromissos da nova com a velha elite no poder, criando assim interditos ao acesso das classes sociais às instâncias de decisão do Estado.
} 
produção e comercialização de tais bens sejam editadas com prioridade, a despeito das demandas sociais.

A ideia de refazer o itinerário daquilo que se chama de genealogia dos movimentos sociais do campo insere-se na percepção de que há muito a ser desvendado (tirar a venda), dos processos instituídos, feito consenso, na forma como se descreve a colonização. Fato é que, grosso modo, resguardadas as variáveis, o modelo de ocupação, pela via colonização, reproduziu o que há de congênito nesses processos: não reconhecimento das realidades e sujeitos locais (invisibilidade), o sentido instrumental feito missão civilizadora, e a imposição do silêncio, uma vez que a alteridade é negada, entre outras.

Essa cultura da colonização é performativa e molda, ainda hoje, não só as formas de ocupação ou a territorialização objetiva do capital, como também elabora e emoldura as mentalidades, o imaginário. Dessa forma, perscrutar pelos caminhos das origens é também uma forma de ruptura com os "contos e narrativas oficiais" instituídas, para que, desvencilhando do "lugar comum", da zona de conforto, evite-se claudicar, intelectual e politicamente, na interpretação dos acontecimentos.

Isso, por óbvio, implica em não aceitar como "normal" o que foi naturalizado: extermínios físicos e culturais dos povos originários, "silenciamento" escarnecedor ante as atrocidades cometidas no campo, cumplicidade ante uma racionalidade embrutecedora e persistente, travestida das formas mais "cosméticas" possíveis. Por isso, a ideia da genealogia, como busca por uma "outra história" dos movimentos sociais do campo, no sentido de ouvir as vozes silenciadas.

Mais do que tratar nosso passado como prólogo, realça-se a importância de observar esses processos de colonização, tanto no discurso, quanto na prática, e localizar as ausências. Ao acionar tais elementos é que se percebem, de forma mais clara, fenômenos que foram relegados ou então subalternizados.

Tais fenômenos se corporificam em sujeitos coletivos que tiveram suas vozes abafadas pelas narrativas institucionais. No entanto, insistem em permanecer, existir e expressar suas memórias insubordinadas, seus gritos 
de resistência. É a passagem de uma polifonia ensurdecida para a "emergência” das falas, contra o silêncio ${ }^{7}$. No entanto, sabe-se que, mais que resgate histórico, fundamental é problematizar tais "emergências", caminho possível de acolhimento de outros olhares, outras perspectivas.

Vale aqui, nesse momento, referenciar Michel Foucault (1979), a fim de elucidar esse processo de reconstrução do conhecimento, na perspectiva de buscar perceber, nessas origens, indicativos e luzes para interpretar o hoje das lutas dos camponeses:

Chamemos provisoriamente genealogia o acoplamento do conhecimento com as memórias locais, que permite a constituição de um saber histórico das lutas e a utilização deste saber nas táticas atuais. Nesta atividade, que se pode chamar genealógica, não se trata, de modo algum, de opor a unidade abstrata da teoria à multiplicidade concreta dos fatos e de desclassificar o especulativo para lhe opor, em forma de cientificismo, o rigor de um conhecimento sistemático. Não é um empirismo nem um positivismo, no sentido habitual do termo, que permeiam o projeto genealógico. Trata-se de ativar saberes locais, descontínuos, desqualificados, não legitimados, contra a instância teórica unitária que pretenderia depurá-los, hierarquizá-los, ordená-los em nome de um conhecimento verdadeiro, em nome dos direitos de uma ciência detida por alguns (Foucault, 1979, p. 152).

Por fim, é necessário constatar que, especificamente no processo de colonização em Rondônia, no período de 1970 a 1984 (Colonização dirigida),

\footnotetext{
${ }^{7}$ Conforme Djamila Ribeiro (2017), é fundamental pensar em “outros lugares” de fala, uma vez que secularmente, as comunidades, sujeitos coletivos e grupos subalternizados, "foram falados" e não falaram. Esta alternativa supõe aquele que fala por si, que é sujeito da fala e não seu objeto. Foi, por sinal, graças à essa "fala sozinha" que se constituíram as hegemonias. $\mathrm{E}$ tais hegemonias fundaram-se em opressões, que por sua vez criaram hierarquias. Assim, é que coletividades e grupos explorados foram oprimidos para manter tal hierarquia. A ideia de lugares múltiplos supõe vozes múltiplas, possibilitando pensar em outra epistemologia, que nasce justamente destes outros lugares, destas outras falas. Para maior aprofundamento, ver Djamila Ribeiro (2017).
} 
coube ao Estado a gestão da destinação das terras, do controle ${ }^{8}$ e seleção das famílias, inclusive destinatários de créditos. É o Estado que cria, produz e reproduz formas assimétricas na dinâmica das relações sociais no campo. Mas também é esse Estado que, quando lhe convém, coopta lideranças da sociedade, ou mesmo cria lideranças e as "ocupa" no aparelho de Estado da região (Becker, 1990).

Por outro lado, como já demonstrado, a ação da população também retrata seu poder e influência, através das lutas e resistências, através do movimento associativo, mas, sobretudo, na força organizacional, espontânea ou articulada na luta pela terra, e diante dos conflitos. Se é possível dizer que nessas interações se reproduz ou mantém-se o espaço para a integração da organização do capital? Sim, mas não nos mesmos moldes, e nem sempre com as mesmas inspirações.

O espaço agrário/agrícola, então, será o espaço-lugar, não só onde o transcurso da história se mostra, mas também onde se constituem os atores sociais e os espaços de relação (Santos, 2001, p. 80). É nesse espaço, ainda, que hegemoniza uma "lógica exógena", ou seja, onde se anuncia o discurso da integração, desde que mantida a estrutura substantiva da desigualdade. Igualmente, nesse espaço, processa-se uma "dialética exógena”, uma vez que se trata de um espaço onde coexistem diferentes perfis e interesses, com expectativas igualmente distintas. Nesse cenário e sob tais determinantes, as lutas sociais do campo materializaram-se em distintas organizações e movimentos sociais, conforme tabela abaixo.

\footnotetext{
${ }^{8}$ Questiona-se se esse controle não objetivava, estrategicamente, propiciar as condições adequadas à transformação do excedente migracional em reservas de subsistência e mão-deobra para os empreendimentos agropecuários na nova fronteira agrícola (Turchi,1981). Além disso, reflete-se que a política institucionalizada deixou a grande maioria dos camponeses migrantes relegados à própria sorte, tendo que encontrar soluções por seus próprios meios. Isso se tornou evidente, uma vez que a "política de contrarreforma agrária" objetivava apenas a monopolização das terras pelos grandes negociantes, grileiros e empresários. Ver, nesse sentido, Moser e Ernesto (2016).
} 
Tabela 4 - Relação das principais organizações do campo em Rondônia e ano de fundação

\begin{tabular}{|l|l|}
\hline \multicolumn{1}{|c|}{ Organização } & Ano \\
\hline Comissão Pastoral da Terra - CPT/RO & 1979 \\
\hline Movimento dos Trabalhadores Rurais Sem Terra - MST & 1988 \\
\hline Articulação Central Assoc. Rural de Ajuda Mútua - ACARAM & 1989 \\
\hline Associação dos Produtores Alternativos de Ouro Preto - APA/OPO & 1992 \\
\hline $\begin{array}{l}\text { Federação dos Trabalhadores na Agricultura de Rondônia - } \\
\text { FETAGRO }\end{array}$ & 1993 \\
\hline Movimento dos Pequenos Agricultores - MPA/RO & 1995 \\
\hline Movimento Camponês Corumbiara - MCC & 1996 \\
\hline Liga dos Camponeses Pobres - LCP & 2000 \\
\hline
\end{tabular}

Fonte: Própria Autoria, 2017

\subsection{MAPEANDO A PESQUISA: FORMAS DE ABORDAGEM E LOCALIZAÇÃOTEMPORAL}

Dados e números muitas vezes comportam uma frieza que não condizem com a dura face da realidade. $O$ que não pode ser traduzido em palavras, muitas vezes, também permanece invisível. Nesse sentido, tanto a cegueira quanto a desmemória acabam cumprindo uma importante finalidade: a sustentação das narrativas oficiais e instituídas, de modo que legitime as coisas como são dadas, contadas e constituídas. Dessa forma, a resistência no campo, na história de Rondônia, via de regra foi submersa por controversas narrativas. Afinal, resistir é contestar, é sair do plano, e isso subverte e incomoda.

Para o procedimento da pesquisa, aqui sistematizada, adotaram-se os seguintes instrumentais: 1) pesquisa documental em documentos e acervo em geral, especialmente do Incra; 2) entrevista em profundidade com 
atores-chave dos movimentos sociais do campo e servidores públicos ${ }^{9}$; e 3) levantamento e coleta de dados, em caráter qualitativo e exploratório, em eventos, reuniões, seminários e cursos realizados pelos movimentos sociais do campo. Combinaram-se, portanto, elementos quantitativos, qualitativos e exploratórios, articulando, assim, tanto as abordagens de dados objetivos como a percepção de elementos de percepção subjetiva, elementos simbólicos e observações experienciais que constroem, ordenam e sinalizam as "construções sociais" da atividade humana coletiva.

A pesquisa de campo ${ }^{10}$ se configura, ainda, como de caráter exploratório, ou seja, buscando estudar o fenômeno dos movimentos sociais, na forma como atuam, como se representam. Por isso, foram levantadas algumas hipóteses, feita uma demarcação temporal, para a observação do caso concreto, no âmbito em que se constituem, na forma como se representam e nas maneiras como se relacionam com agentes externos, especificamente o Estado, através de suas autarquias. Assim, a meta prioritária, mediante a pesquisa de campo e coleta de dados, visou à compreensão da ação de sujeitos coletivos, em um território específico, o campo ou a área rural, além das explicações dadas como evidentes ou amparadas pelo senso comum teórico, inclusive.

Já em relação ao Órgão Público (Incra), a abordagem se deu nos quadros funcionais dos servidores públicos, concursados ou nomeados. Distribuem-se por seções, como Gabinete, Sala da Cidadania, Ouvidoria Agrária, Secretarias, Divisões de desenvolvimento e obtenção, entre outras. Tratou-se, em sentido mais amplo, de um processo de sondagem com vistas

\footnotetext{
${ }_{9}$ Tais entrevistas tiveram um caráter de abordagem qualitativa e exploratória, para levantamento de dados, opiniões, tendências, que viessem, posteriormente, ser analisadas sob critérios teóricos e analíticos. A escolha dos servidores se deu de forma espontânea e aleatória, mas envolvendo tanto aqueles "antigos" da casa (INCRA) quanto os "novos". Nesse sentido, moldou-se também, pela disponibilidade e oportunidade, assim como contou com entrevistas (gravadas e anotadas), seja daqueles que estavam na ativa, seja daqueles que já passaram pela autarquia. Ainda, em sede informativa, a pesquisa junto ao INCRA em Rondônia, contou também com análises comparadas de pesquisa, de caráter assemelhado, realizada na Superintendência Regional do Incra em Marabá (Castro, 2013).

${ }^{10}$ Informa-se que o objeto específico na pesquisa de campo e colheita de dados dos movimentos sociais mirou, sobretudo, a perspectiva de perscrutar a compreensão da relação Movimentos-Estado, no olhar dos participantes desses grupos e movimentos sociais em relação ao marco temporal delimitado nos "governos de esquerda" (2003-2016).
} 
a aprimorar o conhecimento sobre o processo interativo entre Movimentos sociais do campo e Estado.

$\mathrm{Na}$ análise e sistematização, os dados foram relacionados por temas. Dessa forma, tornou-se possível verificar a triangulação dos elementos ou evidências, e assim justificar ou legitimar os resultados obtidos pela investigação.Junto aos segmentos dos movimentos sociais docampo,foram realizadas 160 entrevistas entre pessoas que estão vinculados (diferenciadamente) aos movimentos sociais do campo: lideranças, militância e simpatizantes.

Para que pudesse manter um horizonte aberto para as análises, buscou-se levantar um perfil dos entrevistados na perspectiva de inserção ou vínculos de origem e manutenção. Por isso, buscou indagar sobre o tempo que eles passaram a atuar em algum tipo de movimento ou organização social do campo, ou que ainda mantivessem, em seus objetivos, aqueles correlacionados às demandas específicas do meio rural.

No Gráfico 2, retrata-se, portanto, o tempo de adesão à militância dos entrevistados em relação aos movimentos e organizações sociais do campo em Rondônia. Para melhor visualização, optou-se, na sistematização, por dividir essa categoria temporal em décadas, a fim, inclusive, de perceber melhor os elementos de continuidade nos distintos contextos da recente histórica socioeconômica e política de Rondônia.

Gráfico 2 - Adesão à militância

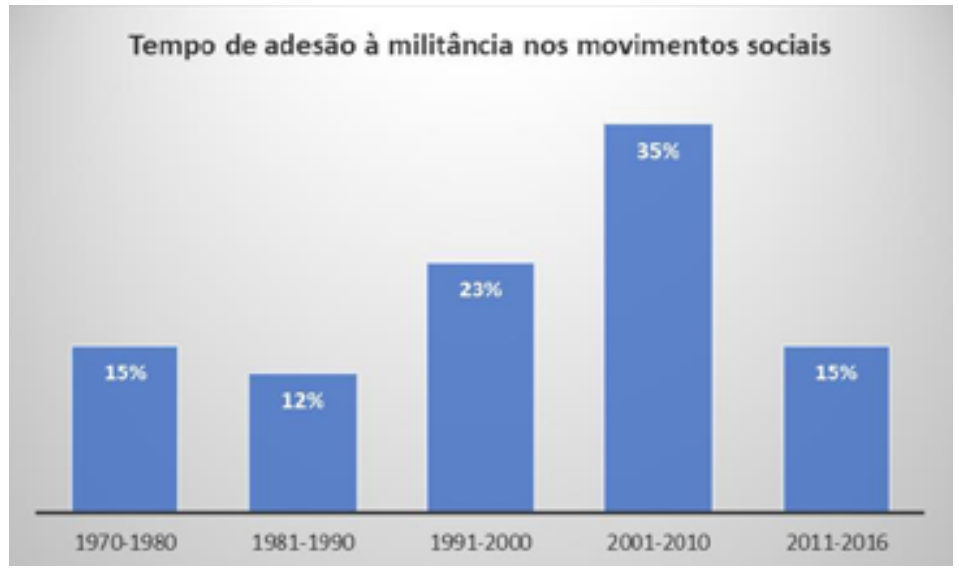

Fonte: Própria Autoria (adaptado) de Pesquisa de campo, 2016/2017 
A maior parte dos entrevistados iniciaram suas atividades nos movimentos sociais do campo, entre o final da década de 1990 até 2005 . No contexto, o Estado de Rondônia vive um período de forte mobilidade interna, ante a abertura de novas frentes agrícolas, ao passo que, nas áreas de colonização originária, avança o modo de produção voltado para a pecuária, o que ativa ainda mais o ciclo migratório. A abertura de novas frentes, tal qual antes, no adensamento da ocupação, ao longo do eixo viário, reproduz a velha lógica do desmatamento irracional, da extração ilegal de madeiras, nomeado por muitos como "amansamento da terra". Trata-se de um período de forte atuação dos movimentos sociais, bem como de fortalecimento do associativismo, entre eles das associações com práticas de ajuda mútua.

Quanto à perspectiva da Reforma agrária como política de Estado e de governo, há que se contextualizar, brevemente, o radical recuo da política agrária no Governo Temer, a partir do segundo semestre de 2016. A consumação do golpe ${ }^{11}$ mudou radicalmente a conjuntura da questão agrária. Assim, um conjunto de medidas passou a ser rapidamente implementado, compondo os novos arranjos institucionais com as restrições orçamentárias, sobretudo em áreas sociais. Esse contexto está intimamente associado ao empoderamento do espaço político da Bancada ruralista, como moeda de troca em relação ao seu apoio "incondicional" ao impeachment. Vislumbrava-se o cenário do enfraquecimento das políticas fundiárias.

Cumprindo uma agenda negociada de apoio no Congresso Nacional, junto a esta mesma Bancada ruralista, o governo editou a Medida Provisória no 759/2016, camuflando a questão agrária com a questão da regularização fundiária urbana. $\mathrm{Na}$ narrativa oficial, a ideia foi imprimir transparência no processo de reforma agrária e regularização fundiária. Assim, apresentou-se, entre os principais motivos, dar celeridade aos processos de privatização de terras públicas, via titulação, bem como "consolidar" os

\footnotetext{
${ }^{11}$ Muitas são as abordagens analíticas e interpretativas acerca do golpe de 2016. Em geral, tratou-se de uma insurgência daqueles que não aceitaram o resultado das eleições de 2014. Mas também há elementos que o classificam como "a retomada dos privilégios", por parte de um setor da sociedade. Constata-se, portanto, que, além de um golpe de Estado, foi um golpe patriarcal, sexista, capitalista e midiático, com forte anteparo no Poder Judiciário. Para abordagem e análise mais aprofundadas, consular Elen Cristina Geraldes et al.(2016).
} 
assentamentos, pela via da regularização, como principal mecanismo para emissão de títulos. (Cleps Junior, 2017).

Em breve, sob as "tramas internas" do Congresso Nacional, a Medida Provisória seria aprovada na forma da Lei no 13.465/2017. Assim, uma política de titulação alterna um programa político de Reforma agrária, nos termos constitucionais (Reforma agrária de papel). Tal medida, em muito, conforme a contranarrativa dos movimentos sociais, reaquece o mercado de terras, facilitando o comércio de terras em áreas de assentamento.

$\mathrm{Na}$ Amazônia, a proposta imunizou a grilagem de terras, ao criar condições, a custo baixíssimo (10\% do valor real), de regularizar extensas propriedades de até 2.500 hectares de terras. Consumando tal proposta, o Governo Temer extinguiu o Ministério do Desenvolvimento Agrário e instituiu procedimentos administrativos que neutralizaram a participação dos movimentos sociais do campo, nos procedimentos de indicação de áreas, cadastramento e seleção de possíveis beneficiários. A dinâmica proposta objetivou, na prática, municipalizar, ao máximo, os procedimentos de efetivação da política agrária. Os cortes orçamentários e a suspensão de programas de financiamento, como uma espécie de obituário político da Reforma agrária no país ${ }^{12}$, sucederam as alterações legislativas.

Nesse sentido, os movimentos sociais do campo, em muito, resultaram em "reféns do contexto", vivenciando uma realidade que transitava entre a "confusão administrativa" ante às novas regras à espera de regulamento, e os processos de enfrentamento, tanto em nível nacional, quanto regional. A atuação dos movimentos sociais pautou-se, assim, por mobilizações em torno de agendas locais, enfrentando essa inação do Estado, corporificada na burocracia dos órgãos agrários. No entanto, os processos de resistência, enfrentamento e mobilização, mesmo no cenário adverso, permanecem. Afinal, essa contraofensiva, roteirizada pelo governo, não é localizada, ou seja, advém desde os governos anteriores, também comprometidos com a lógica burguesa-patrimonial.

\footnotetext{
$\overline{{ }^{12} \text { A lei no } 13.465 / 2017}$, considerado o novo marco legal da reforma agrária, retrata e ampara esta análise, sem subterfúgios. Tal visão, inclusive, está claramente manifesta na exposição de motivos, do referido estatuto legal.
} 
Portanto, aquilo que os movimentos sociais do campo têm, e mantêm, de específico avança em seus repertórios de ações coletivas, adequando-se aos atuais desafios. A inflexão, entretanto, no conjunto das ações organizadas, se deve muito mais à conjunção de dois fenômenos que, cada vez mais, vão se tornando expoentes: a radicalização da violência privada e patrocinada contra os movimentos sociais (despejos por milícias, assassinados, violência física) e a criminalização jurídico-policial dos movimentos sociais, em especial de suas lideranças. Essa, aliás, é a principal marca contemporânea na repressão aos movimentos sociais. Essa lógica de criminalização, inclusive, em regra, é precedida e preparada por uma ofensiva em meios de comunicação, com o objetivo de difamar a ação dos movimentos e qualificar suas ações como atos de subversão, baderna e ações criminosas (crime organizado).

\subsection{IDENTIFICANDO AS ORIGENS E AS FORMAS DE ORGANIZAÇÃO COLETIVA}

Buscando compreender, pelo menos em parte, o perfil dos entrevistados e, via de regra, compreender como se caracterizam os movimentos sociais do campo em Rondônia, na forma como se organizam coletivamente, dois outros aspectos foram levantados. $O$ primeiro abordou o envolvimento nas origens e assim procurou entender os vínculos primeiros que ensejaram a inserção do entrevistado a alguma forma de organização social ou movimento social. $\mathrm{O}$ segundo aspecto diz respeito à organização à qual está vinculado o entrevistado, seu vínculo atual de militância. Nesse sentido, conforme a pesquisa realizada, indagados sobre a origem da militância ou da participação em movimentos sociais do campo, manifestaram-se, conforme o Gráfico 3.

As origens e a forma de organização coletiva estão inseridas no recorte espaço-temporal que compreende o contexto da colonização. Há que se registrar, portanto, que a contextualização da "questão agrária" a coloca sob a perspectiva de uma intervenção dirigida (estatal), ou seja, de "fora para dentro". Tal recorte está aqui demarcado pelo fato de se reconhecer 
que, no conceito ampliado de campesinato, deveriam estar incorporadas as lutas territoriais, os enfrentamentos e resistências dos povos originários. No entanto, não é esse o enfoque da pesquisa.

Nesse recorte, ainda, não se objetivou demarcar um perfil coletivo desses atores da colonização: grandes contingentes de migrantes-colonos. Não é a mobilidade humana o objeto da pesquisa, muito menos o aprofundamento das causas e efeitos desse fenômeno. A preocupação de fundo mira nos processos mais ou menos organizativos e participativos dos grupos e movimentos sociais. Naquilo que se caracterizou, sob a forma de enfrentamento, resistência e mesmo sobrevivência perante o dirigismo político do Estado nos programas fundiários e agrários. Percebe-se, assim, que o enfoque investigativo tem como centro a questão agrária (conflitos por terra) e fundiária (ordenamento socioterritorial) da propriedade da terra. Assim, buscando entender, nas origens, as possibilidades e as condições que determinaram a militância em setores mais ou menos organizados, bem como nos movimentos sociais, é que se investigou a origem da militância.

Gráfico 3 - Sobre a origem da militância ou vínculo original

\section{Origens da militância/engajamento}

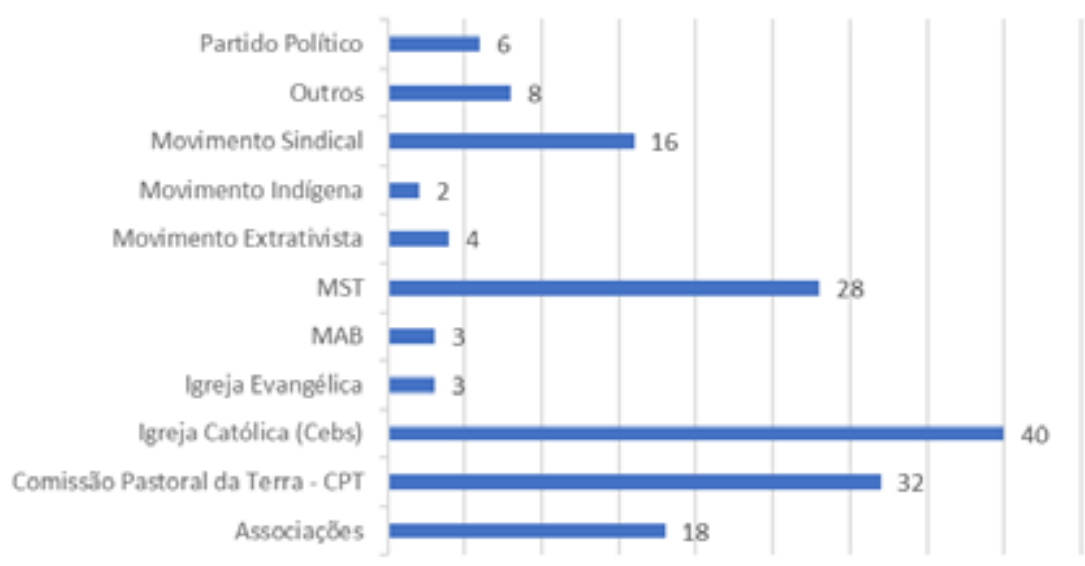

Fonte: Própria Autoria (adaptado) de Pesquisa de campo, 2016/2017

As informações expressas no Gráfico 3, sobre a origem da militância, mostram algumas variáveis que merecem, ainda que parcialmente, alguma 
análise. Em primeiro lugar, a influência da Igreja católica na "produção" do engajamento e militância nos movimentos sociais do campo. Conforme Ilse Scherer-Warren (1987), a atuação e a vivência das Comunidades Eclesiais de Base (Cebs) representam, à época (anos 1980 em diante), um caráter "novo", uma "revolução no cotidiano", que impulsiona o engajamento nas lutas sociais. Trata-se de um modelo alternativo, no interior da Igreja, com uma forte pregação à vivência da solidariedade, ou ao estabelecimento de um relacionamento solidário, entre os homens. É alternativo, porque frequentemente foi vivenciado de forma ambígua, ou seja, em um espaço onde esse "novo" se confronta com as tradições de dominação hierárquica, fortemente vinculadas a uma dinâmica hierárquica e centralizadora, portanto. No interior desse contexto, a proposta das Cebs desenvolve um projeto básico de democracia e socialismo, no sentido que esses sejam vivenciados no nível da prática cotidiana (Scherer-Warren, 1987).

Em Rondônia, em grande parte, o protagonismo dessa experiência foi dinamizado pela Diocese de Ji-Paraná, com forte apoio de setores da hierarquia, especialmente na atuação de seu bispo, à época, Dom Antônio Possamai. Importante ressaltar que, no plano de uma Igreja mais vinculada à base, os colonos-migrantes também resgatavam as experiências trazidas de seus locais de origem. Assim, a ideia de constituírem-se em comunidades de base, de desenvolverem trabalhos pastorais, de se engajarem na multiplicação da proposta, por meio de missões populares, conjugava-se com o estímulo do clero local. Nessa forma de "Igreja de base", caracterizava-se, além de uma proposta descentralizada de organização, o protagonismo de lideranças, respondendo, assim, à carência de agentes de pastorais clérigos, na condução dos trabalhos religiosos.

Além disso, as Cebs acabaram se tornando as referências originárias na multiplicação de lideranças que passaram a ingressar diversos segmentos e organizações que tinham como objetivo a luta pela terra, contra o êxodo rural, a agroecologia etc. Dessa referência, surge a Comissão Pastoral da Terra, fortalece-se o movimento sindical, o associativismo de ajuda mútua, Projetos de assessoria e acompanhamento dos camponeses (Projeto Pe. Ezequiel), e Escolas Família Agrícola (EFAS). É das fileiras das Cebs que 
provém, igualmente, grande parte dos militantes e agentes dos movimentos sociais do campo, no Estado de Rondônia. Foi através desta atuação conjugada da Igreja de base (leigos e hierarquia) que se foi firmando o papel de denúncia dos vários tipos de injustiça e violência, como também o papel de mediação, demandadas em outras instâncias. De um lado, portanto, organiza-se todo um trabalho de consciência política, de protagonismo e participação e, de outro, potencializa-se a inserção atuante nos movimentos, lutas e organizações sociais.

O fundamento dessa atuação está contextualizado também pela preponderância da Teologia da Libertação, como ferramenta de leitura e motivação, quanto ao papel da Igreja e da prática cristã. Rompendo com uma tradição eurocêntrica, a Teologia da Libertação inova, no método e nos fundamentos. Em primeiro lugar, propõe uma dimensão histórica para a perspectiva teológica. É no interior dos contextos históricos, submetidos à situação de opressão, que essa Igreja exerce sua missão. Assim, o objetivo fundamental dessa teologia é propiciar mecanismos que potencializem a libertação ante essas múltiplas formas de opressão (Scherer-Warren, 2011). $\mathrm{E}$, assim, o principal princípio orientador é a "opção preferencial pelos pobres", com o consequente engajamento dos cristãos contra a opressão.

Em segundo plano, é o próprio homem e a própria mulher que devem ser os protagonistas e sujeitos de seu destino, histórico e pessoal. Para tanto, seja no engajamento nos movimentos sociais, seja na atuação política comprometida, seja na defesa de valores universais, é nesses espaços que vai ser reconstruída a dignidade humana, à luz do evangelho. Em terceiro lugar, vincula-se a libertação histórica à libertação integral. Em outras palavras, a salvação inicia-se no "aqui e agora" históricos. Portanto, a luta contra as servidões temporais, fruto das injustiças sociais, acontece não no abstrato ou no porvir, mas nas condições estruturais, no plano econômico, político, social e cultural. A salvação opera-se no interior da história humana e não depois (Scherer-Warren, 2011).

Em relação ao segundo aspecto, a sondagem acerca da forma de organização coletiva em que se encontram vinculados, $51 \%$ dos entrevistados informaram que atuam em algum movimento social; $22 \%$ militam no 
movimento sindical, e $28 \%$ atuam sob a forma de organização do associativismo. Para fins de uma rápida caracterização, baseada na literatura contemporânea, entende-se que as ações coletivas organizadas, na perspectiva de movimentos sociais, guardam, entre outras, as principais características, donde se destacam:

- Seja uma ação coletiva de caráter sociopolítico e cultural, através de formas organizadas a fim de que a população ou setores dessa população possam expressar suas demandas;

- Adotem diversas e distintas estratégias, que vão da denúncia a formas de pressão, inclusive mobilização por meio de redes sociais (repertórios de atuação);

- Possuam uma identidade coletiva, ou busca-se construir tal identidade no processo dinâmico de mobilização, articulação e ação;

- Suas demandas sejam politizadas e estabeleçam pela própria ação uma "arena específica”, um campo de disputa, um espaço onde sua força social se expresse e se articule;

- Atuem em oposição, ou mesmo em situações de conflitos, litígios e disputas. Pressupõe que tais ações acabem desenvolvendo um processo social e político que defina ou redefina a própria identidade coletiva do movimento, em vista de interesses em comum;

- Orientem-se pelo princípio da solidariedade, como um processo que se constrói a partir da própria base;

- Possua liderança, em geral colegiada;

- Portem, ou sejam movidos por um projeto de vida e de sociedade. ${ }^{13}$ No cenário específico de Rondônia, os movimentos e organizações sociais do campo retratam diferenciadas formas de estruturação. Para uma melhor compreensão, considerou-se, nas formas de organização, quatro grupos distintos que, eventualmente, articulam-se, mas que, via de regra,

\footnotetext{
${ }^{13}$ Tais características dos movimentos sociais são fundamentadas, sobretudo, em Maria da Glória Gohn (2011) e Ilse Scherer-Warren (2006). No entanto, ainda que de caráter normativo ou ideal, a constituição e caracterização do fenômeno dos movimentos sociais são essencialmente moldados nos contextos específicos em que se estabelecem, revelando assim um caráter de dinamicidade que conjuga diferentes pressupostos e caracterizações, de acordo com as condições e oportunidades em que tais movimentos são criados e se difundem.
} 
seguem parâmetros distintos. Essa distinção ocorre, seja na organicidade, seja nos repertórios de ação, seja nos vínculos estabelecidos. Trata-se, pois, de: movimentos sociais ${ }^{14}$, movimentos sindicais, movimento associativo, Organizações Não Governamentais.

Tabela 5 - Formas de organização e repertórios dos movimentos sociais do campo

\begin{tabular}{|c|c|c|c|}
\hline \multicolumn{4}{|c|}{ Formas de participação nas lutas agrárias em Rondônia } \\
\hline Movimentos & $\begin{array}{c}\text { Campo } \\
\text { institucional }\end{array}$ & Repertórios & Organicidade \\
\hline $\begin{array}{c}\text { Movimentos } \\
\text { Sociais (MST, } \\
\text { LCP) }\end{array}$ & Vínculo nacional & $\begin{array}{c}\text { Acampamento, } \\
\text { Ocupações e } \\
\text { Audiências }\end{array}$ & $\begin{array}{c}\text { Centralizada na } \\
\text { coordenação }\end{array}$ \\
\hline $\begin{array}{c}\text { Movimentos } \\
\text { Sindicais } \\
\text { (STRs e } \\
\text { Federação) }\end{array}$ & Vínculo nacional & $\begin{array}{l}\text { Mediação, } \\
\text { Audiências }\end{array}$ & $\begin{array}{c}\text { Centralizada } \\
\text { na coordenação } \\
\text { coletiva }\end{array}$ \\
\hline $\begin{array}{l}\text { Movimento } \\
\text { Associativo }\end{array}$ & $\begin{array}{l}\text { Base local - } \\
\text { registro }\end{array}$ & $\begin{array}{c}\text { Audiências/ } \\
\text { Reuniões } \\
\text { Participação em } \\
\text { instâncias } \\
\end{array}$ & $\begin{array}{c}\text { Centralizada na } \\
\text { Presidência }\end{array}$ \\
\hline $\begin{array}{l}\text { Organizações } \\
\text { Não } \\
\text { Governamentais }\end{array}$ & $\begin{array}{l}\text { Vínculo regional } \\
\text { e Internacional }\end{array}$ & Mediação & $\begin{array}{c}\text { Centralizada na } \\
\text { direção }\end{array}$ \\
\hline
\end{tabular}

Fonte: Própria Autoria (adaptado) de Pesquisa de campo, 2016/2017

A leitura política das formas de participação nas lutas sociais do campo expõe não só a diversidade, nas formas de atuação, como também a própria complexidade que envolve o fenômeno. Em outros termos, há que se constatar que tais formas de atuação e engajamento, além de se contingenciarem pelo contexto histórico das lutas e resistências, podem conjugar formas eventuais nos repertórios da ação coletiva. Isso faz que ora se aproximem, ora se distanciem, conforme o cenário do enfrentamento ou da luta

\footnotetext{
${ }^{14}$ Maria da Gloria Gohn refere-se a esses movimentos como "Movimento Popular Rural", e Ilse Scherer-Warren adota a nomenclatura: "Movimentos Sociais Rurais".
} 
específica. Assim, a depender do momento, os movimentos e organizações sociais do campo lançam mão de múltiplas estratégias e práticas, desvelando a complexidade do fenômeno das ações coletivas.

Lúcio R. Rennó (2003), tomando como base uma sistematização do Banco de Dados do Latinobarômetro, identificou a diversidade nas formas de participação dos grupos sociais e políticos no cenário latino-americano. $\mathrm{O}$ autor reconhece, entretanto, que o fenômeno da participação não pode ser considerado como um fenômeno social único. Mas alerta também que, muito menos, se pode justapor ações combinadas, de forma indiscriminada, em um único indicador. Mediante isso, propõe quatro variáveis possíveis quanto à forma de engajamento:

1. Participação em associações, em nível nacional, motivados por claros objetivos. Nesse caso, tais organizações representam-se como instrumentos de mediação dos interesses organizados;

2. Participação mais localizada, a exemplo do associativismo. São voltados mais para os temas e agendas locais e não nacionais ou de determinada classe;

3. Atuação dos movimentos ambientalistas, com uma dimensão participativa e organizacional diversa da atuação nos movimentos sociais tradicionais. Distinguem-se, em regra, nas estratégias de ação, no recrutamento, no perfil dos membros e na disponibilidade de recursos;

4. Participação em formas específicas de protesto político, consideradas e nomeadas como formas de atividade ilegal e como desobediência civil: invasões de propriedade privada, bloqueios de trânsito etc. (Rennó, 2003).

As duas primeiras formas delineadas são consideradas formas tradicionais ou clássicas de engajamento ou de atuação cívica. No entanto, já é consenso o fato de, recentemente, surgir inúmeras formas de participação não tradicionais, qualificadas como Novos Movimentos Sociais. Tal fenômeno se evidencia, sobretudo, em época de multiplicação de instrumentos de comunicação e mobilização via o instrumental da rede (internet). As duas últimas formas apresentadas têm crescido em relação à articulação em 
forma de rede, margeando as questões paradoxais da desigualdade econômica e das causas estruturais geradoras de injustiças sociais.

Quanto à dimensão do protesto político, sinaliza para um caráter mais temporário e, portanto, menos estruturado da ação coletiva. No entanto, é adotado também pelos movimentos sociais tradicionais, como forma de fazer o enfrentamento direto, garantir a visibilidade política do fenômeno e como mecanismo alternativo à pragmática burocrática de resolução institucional dos problemas sociais.

É nesse campo que se trava uma verdadeira "guerra de propaganda" contra os movimentos sociais, qualificados como "prejudiciais à democracia”, como "grupos de baderna e subversão". É no bojo dessas "conformações normativas", em forma de categorias, que se constitui o verdadeiro motivo condutor (leitmotiv) para a adoção por parte do Estado na repressão, coação e criminalização dos movimentos sociais do campo. Via de regra, cabe à retórica oficial, assim como aos grupos midiáticos, tal tarefa, muito adotada aliás nos últimos anos contra os movimentos sociais do campo em Rondônia.

\subsection{LOCALIZANDO A AÇÃO: REPERTÓRIOS E CAMPOS DE INTERLOCUÇÃO}

$\mathrm{Na}$ pesquisa sobre os movimentos sociais do campo, foi possível detectar que, em relação à forma de atuação, na perspectiva do interlocutor e da "arena pública" do debate, há importantes variáveis a serem consideradas. Em primeiro lugar, o locus específico de atuação define o alcance das estratégias a partir da "arena pública", onde tal interação ocorre. Isso ocorre, por exemplo, em relação à participação em conselhos municipais ou regionais. Em regra, esse é um espaço criado ou definido pelas Instituições ou Estado, em geral sob suas regras e controle. A participação de atores dos movimentos sociais nesse espaço pode garantir visibilidade em determinados setores da agenda pública, mas pode se tornar um espaço também de legitimação de tal agenda, mais que de efetivação ou concretização das demandas suscitadas. 
Em segundo plano, o papel do interlocutor ou interlocutores pode redefinir, em muito, o resultado das demandas dos movimentos sociais. Se, por exemplo, a interlocução se dá entre um deputado e uma liderança, ou conjunto de lideranças, a caracterização dessa relação dependerá do grau de envolvimento e compromisso desses determinados atores. A partir deste "laço afetivo", pode-se suscitar a adoção de estratégias pré-definidas, em vista dos objetivos esperados. A mediação, nesses casos, estará objetivamente mais refém de práticas clientelistas ou eleitoreiras, influenciando direta ou indiretamente no resultado buscado.

Um aspecto indicativo da pesquisa foi a constatação de que, na fronteira das relações entre Estado e movimentos/organizações do campo, a participação em Conselhos revelou-se como a mais ativada forma de "participação" em nome das coletividades do campo. Há, sim, muito que indagar sobre as condicionantes dessa forma de ação coletiva, seus limites ou problemas que enfrenta. No entanto, na forma como os militantes/agentes dos setores organizados do campo se retratam, há de considerar esse espaço como um espaço participativo sobre questões relevantes atinadas às questões rurais ou do campo.

Quanto à participação em conselhos, mesmo que, nas origens e na forma como operam, prevaleça, em muito, uma "ordem estatal”, não há como deixar de evidenciar, nesse espaço, situações que potencializem tanto a visibilidade dos problemas enfrentados, como de publicização das principais questões. Tal visibilidade, entretanto, é permeada direta ou indiretamente por conteúdos e motivações políticas a incidir, em maior ou menor grau, na concretização de direitos destinados ao público ali representado. 
Gráfico 4 - Formas de atuação dos movimentos sociais em relação à interlocução

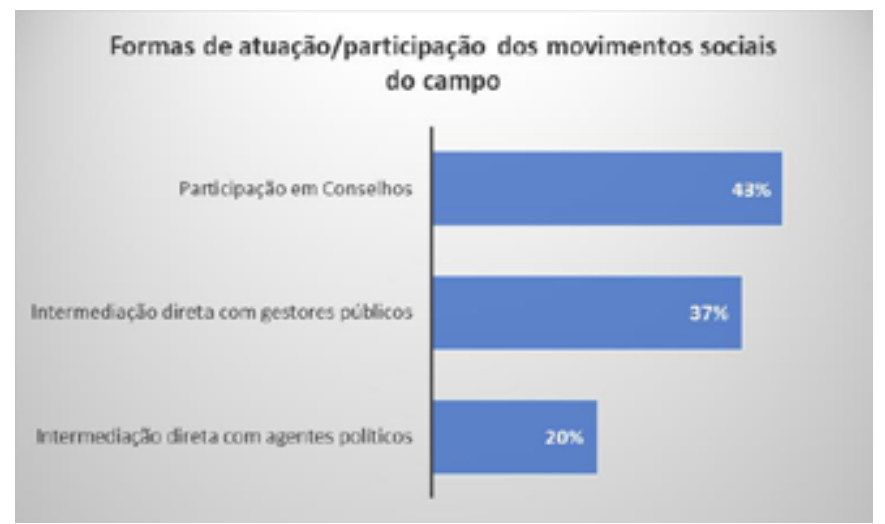

Fonte: Própria Autoria (adaptado) de Pesquisa de campo, 2016/2017

Conforme o modelo de engajamento das lideranças e ativistas dos movimentos e organizações sociais do campo em Rondônia, é a participação em Conselhos municipais ou regionais que define sua militância, para a maioria. Percebe-se, também, que a forma de participação, mediante a intermediação direta com gestores públicos, reflete uma tendência dos movimentos sociais mais organizados, enquanto a intermediação com agentes políticos (Governador, Deputado, Prefeito e Vereadores) sustenta-se como uma estratégia, em regra, bem utilizada. É nesse tipo de intermediação, aliás, que configura, conforme o contexto, as relações fundadas em conhecimento, amizade e clientelismo (troca de favores). Aqui, a perspectiva se desdobra em duas situações concretas: a possibilidade de intervenção conforme o alinhamento de determinado agente político, e o contexto político no qual se desenha o governo de plantão (situação ou oposição).

É possível também considerar que novas formas de interação se processam decorrentes da presença de atores ou ativistas dos movimentos sociais no aparato estatal. Nesse caso, é preciso superar o enfoque que se dá na atuação dos movimentos sociais do campo perante o Estado, além da ação contenciosa dos movimentos (Abers; Serafim; Tatagiba, 2011).

Essa abordagem, que pressupõe formas culturalmente codificadas de atuação, sob forma de conflito, redimensiona a ação coletiva dos movimentos 
sociais na forma como tais coletivos se engajam em determinada ação coletiva. Assim, para essa abordagem, é preciso pensar inclusive em "repertórios de interação", a fim de perceber relações colaborativas ou padrões colaborativos de relação entre movimentos sociais do campo e Estado. Isso, inclusive, leva a conferir a diversidade de estratégias adotadas e incorporadas, sobretudo pelos movimentos sociais do campo, estratégias estas usadas, combinadas e transformadas no âmbito da relação nessa nova dinâmica de interação (Abers; Serafim; Tatagiba, 2011, p. 332).

As autoras aqui referenciadas, observando o cenário brasileiro, consideram que os movimentos sociais não apenas se posicionam no campo da negociação com o Estado (o que sugeriria a dinâmica da contenção ou contenciosa), mas investem em formas de atuação no interior do próprio Estado (o que sugere a dinâmica da interação). Ou seja, acabam transformando o próprio Estado em "espaço de militância política" (Abers; Serafim; Tatagiba, 2011, p. 331). E, nesse sentido, numa visão conjuntural, sistematizam quatro rotinas de interação:

- Protestos e ação direta - inclusive quando há colaboração com o Estado, então inserido no ciclo da negociação;

- Participação institucionalizada - ou seja, pelos meios institucionais: conselhos, conferências etc;

- Política de proximidade - nos contatos pessoais entre atores do Estado e dos movimentos;

- Ocupação de cargos dentro do aparelho estatal - via aproximação de conhecidos que facilitem a conexão entre os dois polos (Abers; Serafim; Tatagiba, 2011).

À luz do levantamento sistematizado pela pesquisa, é possível compreender alguns elementos que caracterizam a atuação dos movimentos sociais do campo. Em primeiro lugar, a forte dimensão das "interações colaborativas". A ocupação dos espaços locais (Conselhos) e dos espaços regionais da administração pública (gestão) realça a presença dos agentes na "arena estatal", porém, redimensionada. Ou seja, esses espaços possíveis de participação combinam performances de enfrentamento, mas 
também de negociação. Ao mesmo tempo, é o espaço ocupado onde as demandas são apresentadas.

Em grande parte, a opção por essa forma de mediação estabelece-se nas "limitações" do próprio Estado, na sua inação ou na falta de recursos ou investimentos. Retrata, numa leitura mais ampliada, o "descaso político" com a questão agrária e camponesa. Em segundo lugar, essa forma de interação, no cenário político, expõe ainda um campo de relações, em grande parte, personalizadas. Há fortes indícios de que os espaços instituídos, principalmente os "conselhos", são um campo de influência e de vínculos, dependendo, em muito, do governo de plantão ou de aliados políticos.

A prática associativista (associativismo) comumente é tida e mantida como espaço de clientelismo eleitoreiro, onde muitas vezes o atendimento da demanda é vinculado a simpatias demonstradas na forma de "trocas de influência”. Em terceiro lugar, é relevante ponderar que a força dos movimentos sociais é muito influenciada pelos ciclos políticos, econômicos e, por associação, ideológicos. As condições de possibilidade - ou o conjunto de oportunidades (que muitas vezes fomentam uma ação coletiva organizada) - estão sujeitas às circunstâncias e contextos, seja na adversidade encontrada, seja nas mudanças ou alterações conjunturais.

Em relação ao espaço da interlocução, ainda há um indicativo importante que merece atenção: a relação com a Ouvidoria Agrária Nacional. Criada em 1999, ainda no Governo de Fernando Henrique Cardoso, a Ouvidoria Agrária Nacional objetivava, sobretudo, a negociação e a prevenção dos conflitos no campo. Ainda que limitada em sua autonomia, por ser biônica, representava um espaço, em que, pouco a pouco, os movimentos sociais foram redimensionando não somente sua forma de interlocução, como a própria funcionalidade do órgão.

Em 2010, pelo Decreto $n^{\circ} 7.255$, de 4 de agosto, a Ouvidoria é incorporada ao Ministério do Desenvolvimento Agrário. Além da função de mediação de conflitos, passa a ser um espaço no qual as lutas agrárias vão ganhando expressão. Isso ocorre tanto em relação ao Incra, órgão de gestão da política agrária, mas também em relação à atuação do Judiciário, do Ministério da Justiça, da Secretaria de Direitos Humanos etc. Verifica-se, ao 
observar estudos e documentos elaborados e difundidos pela própria $\mathrm{Ou}$ vidoria (Brasil, 2013), uma precisão no diagnóstico das causas dos conflitos agrários, em regra gerados e mantidos por grandes pretensões privadas e grandes empresas rurais: grilagem de terras, despejo sem ordem judicial, impunidade, extração ilegal de madeira, reconcentração de lotes em assentamentos, porte ilegal de armas, pistoleiros, ocupação de terras públicas e privadas (Brasil, 2013, p, 93). Registra-se, entretanto, pouca ou nenhuma responsabilização da inação do Estado ou mesmo de intervenções ou legitimações judiciais, em completo desatendimento às regras processuais básicas, previstas na legislação.

Há que consignar ainda que, no âmbito da atuação, como instrumento de mediação, a ação da Ouvidoria agrária não se caracteriza apenas mediante a provocação formal dos movimentos sociais ou mesmo instituições públicas. A Ouvidoria possui capacidade de agir de ofício, a partir da tomada de conhecimento do conflito. Enfim, constata-se que a atuação da Ouvidoria, enquanto espaço institucional, objetiva-se tanto pela mediação dos sujeitos sociais e instituições do sistema de justiça, quanto pela mediação dos órgãos estatais, a fim de veicular as questões suscitadas pelos sujeitos coletivos e buscar soluções para a situação específica fundiária, envolvida.

Gráfico 5 - Audiências da Ouvidoria Agrária Nacional

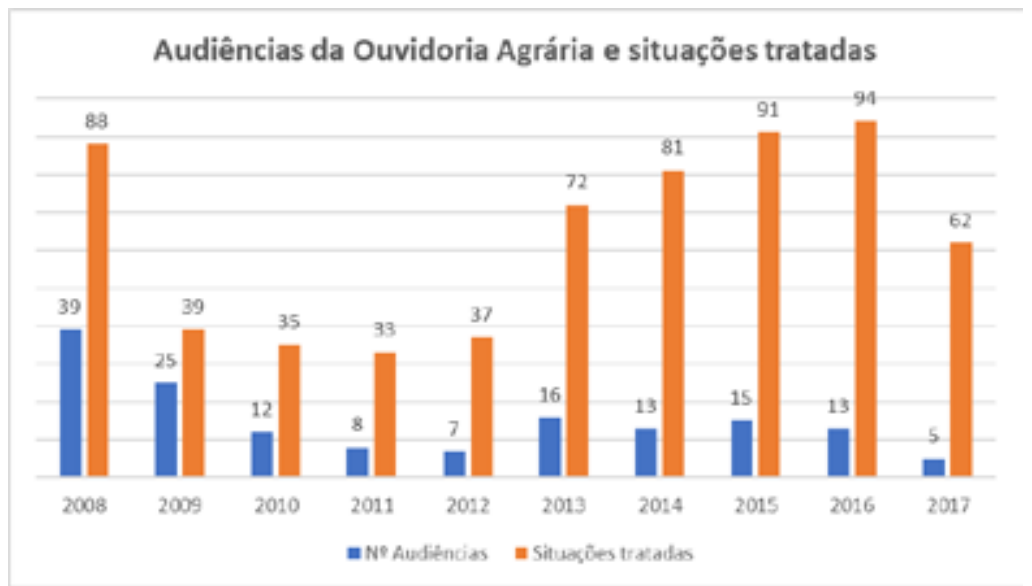

Fonte: Própria Autoria (adaptado) com base em: Ouvidoria Agrária Nacional (OAN), 2016/2017 
Conforme projeção expressa no Gráfico 5, a “instrumentalização” da Ouvidoria Agrária Nacional, como repertório de participação e interlocução dos movimentos sociais do campo, retrata um indicativo importante, no contexto das lutas agrárias em Rondônia. Da multiplicação de reuniões e agendas dispersas, os movimentos sociais do campo vão tomando consciência da importância em transformar tais audiências em grandes eventos, onde se ampliam a análise dos casos e o acesso às informações dos procedimentos e entabulam-se as medidas reivindicadas.

No entanto, a verticalização das demandas trazidas para tais audiências, nos últimos quatro anos, dimensiona um período de agravamento da violência, bem como da paralisia política da questão agrária. Assim, o espaço "forjado" das audiências públicas reveste-se de um novo repertório e recriação do espaço de relação entre Estado e movimentos sociais. Trata-se de um formato indicativo também da participação autônoma dos segmentos sociais, um pretenso exercício de democracia direta, voltado à agenda e às demandas do campo.

Contanto, com o golpe de 2016, a atuação dos movimentos sociais do campo passou a sofrer também, nesses novos espaços de atuação, uma série de limitações. No segundo semestre de 2016, o Ministério de Desenvolvimento Agrário foi extinto, como extinta também foi a Ouvidoria Agrária Nacional. A integração do MDA, agora com status de Secretaria vinculada à Casa Civil, e a recriação da Ouvidoria Agrária Nacional, via Decreto 8.955 de 11 de janeiro de 2017, vinculada à Presidência do Incra, são fatos políticos reveladores.

Ninguém extingue algo em funcionamento para recriar sob outros moldes, senão para alterar seus objetivos, ampliar os mecanismos de controle e reeditar sua forma de atuação. Essa é a única leitura possível da recriação da Ouvidoria Agrária. Ao retirar sua autonomia, resta claro que mais que vincular a Ouvidoria à direção da Presidência do Incra, o que se efetivou foi a limitação do espaço da participação dos movimentos e segmentos sociais. Retira-se o caráter da mediação, transformando o órgão em espaço de gestão, discricionariamente condicionada ao humor e à vontade do Presidente do Incra. 
Como se sabe, setores como o Incra e o Ibama tornaram-se, nos últimos anos, um verdadeiro campo de pressões políticas, orientadas pela Bancada representativa do latifúndio-agronegócio. Assim, consolidado o golpe, que foi igualmente apoiado por parcela da sociedade civil, o que se apresenta para os movimentos sociais do campo é uma conjuntura adversa. Isso resulta caracterizado, sobretudo, por um retrocesso democrático ou avanço de uma lógica fundamentalista e retrógrada, em especial, quando se trata de direitos sociais. Além disso, a repressão às lutas agrárias se acirrou, nos últimos dois anos, traduzindo uma forma conjugada de repressão tanto do Estado quanto dos setores patrimonialistas, por meio da violência sob encomenda. Por parte do Estado, a criminalização jurídica e policial é um dos principais instrumentos de refreamento das lutas agrárias.

No entanto, em tempos de repressão, o acirramento da questão agrária acaba vertendo em formas insurgentes, reativação das lutas, resgate de antigas demandas e insurreição de novos segmentos. Se o período atual vai se caracterizando pela narrativa de que agora é o "tempo do agronegócio", imposto como consenso homogeneizador, há de se constatar, todavia, que, no campo, há um amplo espaço e condições de possibilidade de retomadas, de mobilização e de articulação.

Conforme os dados do Incra/RO (SR/17), demonstrados na Tabela 6, no ano de 2017 ocorreram 105 casos de conflitos agrários no Estado, envolvendo em torno de 8.317 famílias articuladas nos movimentos sociais.

Tabela 6 - Conflitos agrários em Rondônia - movimentos, áreas, no de famílias (2017)

\begin{tabular}{|c|c|c|}
\hline Movimentos & No áreas & No famílias \\
\hline INDEPENDENTES & 70 & $5.534^{1}$ \\
\hline LCP & 24 & 1.904 \\
\hline MST & 7 & 662 \\
\hline OUTROS & 4 & 217 \\
\hline Total Geral & 105 & 8.317 \\
\hline
\end{tabular}

Fonte: Própria Autoria (adaptado) com base em: Ouvidoria Agrária Nacional (OAN), 2016/2017 
Uma leitura rápida desses indicadores assinala que é na forma independente (Associações, movimentos espontâneos) que se caracterizam as lutas agrárias no Estado. Não é possível, no entanto, afirmar que se trata de lutas "desorganizadas", uma vez que sustentam um mínimo de organização, em regra via constituição de Associação formal, com registro público e composição de diretoria. Por outro lado, os dados apontam para um protagonismo da Liga dos Camponeses Pobres (LCP), como movimento nacionalmente articulado. Nos últimos dez anos, inclusive, são as lideranças e militantes da LCP quem têm sido alvo prioritário da violência estatal e privada, no contexto regional.

No contexto, há que pontuar que um cenário de violência apresenta, nos últimos anos, um quadro de ofensiva generalizada contra os movimentos sociais do campo: na luta pelo acesso à terra, na defesa dos territórios extrativistas e nas lutas territoriais dos povos originários. Essa ofensiva encontra-se inserida também em um quadro de expansão do protagonismo judicial. Por isso, ganha a conotação de atuação do Estado, de diversas formas: despejos judiciais, em grande parte precariamente fundamentados, "patrulhamento rural" (militar) de forma coibitiva às ocupações de terras pelos movimentos sociais, indiciamento, prisão e denúncias generalizadas contra militantes de movimentos sociais. Em regra, o repertório desse "contramovimento" segue um roteiro de exposições difamatórias nos meios de mídia, cobrança direta das associações patronais e intervenções estratégicas e pontuais de agentes públicos, ligadas a setores de Segurança pública.

Dessa forma, na perspectiva da "judicialização da questão agrária", alinha-se também o que tem se caracterizado como repertório ou estratégica jurídica para a paralisação da política agrária. Uma vez que a questão agrária demanda por conhecimento das próprias determinantes, e sendo uma realidade complexa, tem sido comum o fato de as questões em torno dos conflitos agrários serem analisadas e interpretadas a partir de uma exegese superficial do direito de propriedade. Adota-se, sem nenhum esforço por conhecer a realidade, a aplicação por subsunção de fórmulas prontas, aplicadas a situações históricas amplas. Ignora-se toda uma série de fatores, nem sempre facilmente percebíveis. Assim, a cultura institucional de 
mediação instrumentaliza-se no anseio por tutela de meros interesses, em oposição assimétrica, e muitas vezes acrítica, ao direito à terra, como questão de interesse público e como questão política e social.

Essa lógica, pelo olhar jurídico, alimenta a saída policial e não política para o conflito. Entendimentos como "desordem", "desobediência judicial”, "organização criminosa" ou "associação para atividades ilícitas", não raro, figuram na forma de jurisprudência, na tratativa jurídica da atuação dos movimentos sociais do campo e de suas lideranças.

Conforme levantamento e registro do Incra e da Ouvidoria Agrária Nacional, a demanda por Reforma agrária, materializada nas organizações e movimentos sociais, aponta para um repertório de ação mais pontual, em torno de demandas bastante localizadas, como modo de organização. Nesse cenário, é ainda na forma associativa (associativismo formal) que o maior número de organizações se constitui como ação coletiva, referente às demandas por políticas agrárias.

Gráfico 6 - Proporção das famílias por organizações/movimentos em Rondônia (2017)

\section{\% Famílias por movimentos em atuação em Rondônia}

\section{(2017)}

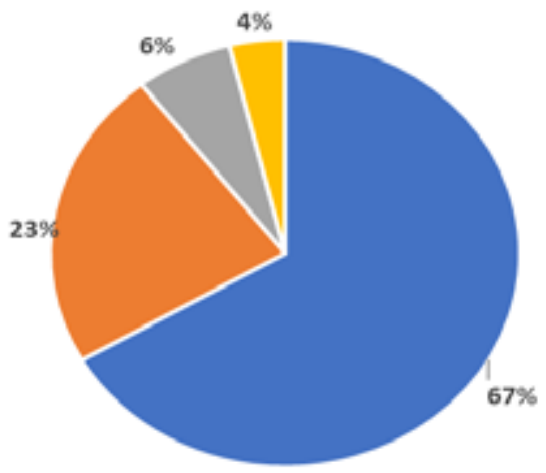

- INDEPENDENTES

- LCP

- MST

- OUTROS

Própria Autoria (adaptado) com base em: Ouvidoria Agrária Nacional (OAN), 2017

O Gráfico 6 ajuda a entender que o fenômeno das ações e mobilizações de grupos autônomos, nos últimos dez anos em Rondônia, refletem, na contraface, a inflexão dos movimentos sociais históricos. Indica também, 
de forma gradativa e insistente, a "construção" de um novo "espaço público", na fronteira entre Estado e Sociedade. Esse espaço, aliás, ajuda a alicerçar e alimentar esse novo tipo de mobilização e repertório.

\subsection{OBJETIVANDO A AÇÃO COLETIVA: AS "BANDEIRAS DE LUTA” DOS MOVIMENTOS SOCIAIS DO CAMPO}

Em uma periodização sumária, referente à questão das lutas sociais no campo, é possível caracterizar o período entre 1970 a 1990 como o tempo da "luta pelo acesso à terra, ou a sua permanência nela, na condição de posseiros. É possível afirmar que o Assentamento 25 de julho (Espigão do Oeste), primeira conquista da organização do MST no Estado, com ocupação iniciada em 1989, reflete um novo estágio da luta pela terra e do protagonismo dos movimentos sociais do campo em Rondônia. Dos anos 1995 a 2005, sob a "sombra" da tragédia de Corumbiara, os movimentos sociais do campo ampliam sua organicidade, fazendo das ocupações o principal repertório. Nesse período surgem, na forma de movimentos sociais organizados, além do MST, o Movimento Camponês de Corumbiara (MCC), e a Liga dos Camponeses Pobres (LCP).

Trata-se, nesse período, da intensificação da luta por reforma agrária strictu sensu, ou seja, na prática dos movimentos sociais, o objetivo, amparado na Constituição, é a democratização da terra. Com isso, questionam também a existência criminosa dos latifúndios improdutivos, em descumprimento da função social. Na prática, a atuação dos movimentos pauta suas reivindicações nas demandas sugeridas para uma política de desapropriação e para efetivação do Programa de Reforma agrária. Em meados dos anos 2000 em diante, intensifica-se a atuação da LCP, dos grupos independentes, organizados em associações, motivados em grande parte pela possibilidade das ações judiciais de retomada (a partir de 2004) e pelas análises e cancelamentos administrativos de áreas de concessões públicas, consideradas inadimplentes.

Dessa forma, as "bandeiras de luta", conforme Gráfico 7, refletem também o contexto político, em âmbito nacional. Reflete, ainda, no perío- 
do, um crescimento do debate sobre a situação fundiária, bem como sobre o papel do Estado. Essa consciência resulta de um processo de organização, mas também transita entre um período de enfrentamento para um período de expectativa e inflexão dessa expectativa, no período dos governos do Partido dos Trabalhadores (2003-2016).

Registra-se ainda que, em âmbito estadual, mesmo com a direção dos órgãos institucionais em "mãos aliadas", não se consumou uma política mais efetiva, voltada para as demandas agrárias no Estado. A ambiguidade representada no contexto não só refreou a política agrária, enquanto política de Estado e de governo, como também multiplicou o apoio financeiro e político ao setor adversário. Em outros termos, aumentaram os subsídios e o apoio aos grupos que se opunham à Política agrária e à Política de reconhecimento territorial dos povos originários: o setor do agronegócio.

Galgado à condição de "paladino do desenvolvimento", o setor do agro $^{15}$ assumirá um protagonismo político cada vez mais influente nos "governos de esquerda”. Essa situação - cenário e perspectiva política contra-hegemônica - é refletida nas bandeiras das lutas nos movimentos sociais. É no "espaço público" (das relações construídas), portanto, que as principais demandas e reivindicações camponesas, territoriais e sem-terra vão perceber a disputa política se tornando cada vez mais adversa.

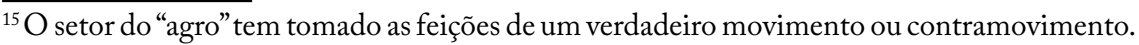
Refletindo sobre o assunto, Regina Bruno (2012) analisa as estratégias e o babitus do setor do agronegócio. Trata-se de uma verdadeira cruzada de convencimento, na qual a ideia principal passa a ser reconstruir a identidade deste setor, sobretudo no sentido de capturar a simpatia do meio urbano. Para tanto, utiliza-se de táticas de mídia, marketing e imagens, buscando corporificar, nas chamadas "agrogentes", a ideia e o símbolo do "agro". Outra área temática que enfrentam é a "questão ambiental", buscando diluir no público a imagem de que este movimento do agronegócio é ecologicamente sustentável, na mesma lógica, anteriormente difundida, da "revolução verde". Atualmente, para a campanha em curso ("Agro - Indústria riqueza do Brasil”), desenvolve-se a ideia mistificadora do agro como tudo: natureza, pessoas, animais. Para maior aprofundamento, portanto, o artigo de Regina Bruno (2012), sobre o movimento "sou agro".
} 
Gráfico 7 - Reivindicações/bandeiras de lutas contemporâneas

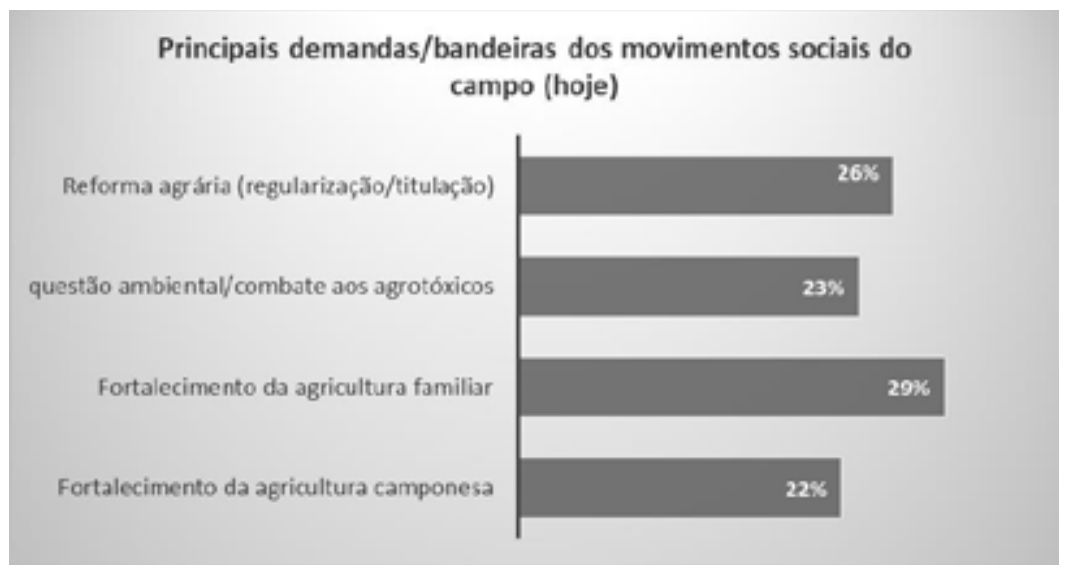

Fonte: Própria Autoria (adaptado) de Pesquisa de campo, 2016/2017

Em relação às demandas dos povos tradicionais, a temporalidade dos processos de luta por direitos e reconhecimentos se divide em três situações específicas. No contexto das lutas indígenas, muitas situações emergiram e agudizaram, sobretudo na década de 1970, ante os equívocos dos Projetos de colonização. As primeiras áreas reconhecidas são do início da década de 1980, contudo, persistem, até hoje, situações dramáticas enfrentadas pelas Organizações indígenas na luta por seus direitos.

Em relação aos seringueiros e soldados da borracha, as articulações de tais movimentos ganharam forma e força com a criação da Organização dos Seringueiros de Rondônia, em dezembro de 1990 (Ferreira, 2009) e, no mesmo período, com a criação de Associações locais. No entanto, no Estado de Rondônia, conforme Mary Helena Allegretti (2002), foi onde aconteceram, concomitantemente no Acre, as primeiras reuniões que deram origem ao Conselho Nacional de Seringueiros (CNS), oficialmente fundado em 31 de agosto de 1985, no $1^{\circ}$ Encontro Nacional de Seringueiros, em Brasília. Conforme Allegretti (2002), a ideia mais inovadora, que consistiu em propor a criação de áreas protegidas para o extrativismo (Resex), na mesma lógica das reservas indígenas, foi proposta pelos seringueiros de Rondônia, em reunião realizada em Ariquemes, em agosto de 1988. 
As lutas por direitos e reconhecimento dos povos tradicionais remanescentes de quilombolas, por sua vez, foram potencializadas em torno da Assembleia Nacional Constituinte (1985-1988), e ganharam impulso, sobretudo, com a edição do Decreto no 4.887/2003. Tal Decreto regulamenta o processo de identificação, reconhecimento, demarcação e titulação das terras ocupadas por comunidades remanescentes dos quilombos ${ }^{16}$. Em Rondônia, portanto, as demandas socioterritoriais quilombolas ganham expressão e capacidade de articulação, a partir da edição de tal Decreto, representando tanto a emergência dessa situação e desses povos, quanto a visibilidade de suas lutas por reconhecimento e direitos.

\subsection{AVALIANDO OS RESULTADOS: AUTOCOMPREENSÃO DA RELAÇÃO MOVIMENTOS SOCIAIS E ESTADO NOS “GOVERNOS POPULARES”(2003-2016)}

Em boa parte das análises, há consenso de que a prática dos movimentos sociais transita, no final da década de 1980, de uma rejeição e negação das agências estatais, campo de interação, para uma reaproximação com o Estado, no final da década, na chamada "era da participação"17 (Ricci, 2013; Martins, 2016, Scherer-Warren e Lüchmann, 2004; Gohn, 2014). Ao que tudo indica, sobretudo a partir da Constituição de 1988, boa parte das demandas sociais e seu debate foram deslocados para novos espaços institucionais. De tal sorte, os movimentos sociais populares acabam perdendo parte de sua força mobilizadora, uma vez que as "políticas de integração" passam a exigir a interação e diálogo com as organizações institucionalizadas (Gohn, 2014, p. 299). São as Organizações Não Governamentais (ONGs) que passam a ganhar importância.

No entanto, na década de 1990 (era da globalização), ainda que aos poucos, vai se fortalecendo uma nova concepção de sociedade civil, inclusive pela reelaboração de uma "política de parceria". Na mesma dire-

\footnotetext{
${ }^{16}$ Tal Decreto do Poder Executivo objetiva dar a regulamentação do Art. 68 do Ato das Disposições Constitucionais Transitórias - ADCT.

${ }^{17}$ Maria da Glória Gohn (2014) entende que a "era da participação” corresponde ao período entre 1978-1989.
} 
ção, recria-se e se fortalece um novo sentido de "esfera pública”, segundo o qual os conflitos são reconhecidos e não reprimidos, e nele se imprime uma nova linguagem, potencializando-se, assim, uma reconstituição do "tecido social”, dilapidado anteriormente pela lógica de regras totalitárias e antidemocráticas.

No campo, é o período de fortalecimento dos movimentos sociais, ainda que evidenciando um tempo de forte repressão e recrudescimento. Exemplo desse cenário foi a violência privada e estatal contra os trabalhadores, consumada em massacres como o de Corumbiara, em 1995, e de Eldorado dos Carajás, em 1996. Dessa forma, sob muitos aspectos, as demandas da década de 1990, por parte dos movimentos sociais do campo, se estabeleceram no campo do enfrentamento, não sem repressão. No entanto, as lutas desses movimentos demarcou, na década, um fortalecimento dos movimentos como atores sociais, que expunham, à nação e ao mundo, as mazelas de uma estrutura agrária viciada, consumada em um patrimonialismo, ainda de feições coloniais.

E assim, por parte dos camponeses, havia, no final da década de 1990, um acúmulo de expectativas, recorrentemente frustradas em articulações palacianas. O sonho constitucional de uma efetivação de direitos no campo e da democratização da terra foi revogado pela Nova República. Poucas eram as perspectivas no final da década de 1990, ainda que o "reformismo agrário" do governo Cardoso prometesse um "Novo Mundo Rural”. O que se viu, na verdade, foi um pacote de políticas públicas endereçadas mais para refrear a ação dos movimentos sociais do campo, bem como tentativas de efetivar uma "reforma agrária de mercado". A proximidade de Lula com os movimentos sociais do campo, desenhado em sua biografia, recompôs as expectativas de implementação de uma série de propostas que tirasse a Reforma agrária do papel e, pelo menos, ativasse os dispositivos constitucionais para tanto.

Esse foi o contexto vivenciado pelos movimentos sociais do campo, e a abordagem da pesquisa considerou esse período dos governos do Partido dos Trabalhadores (2003-2016), para sondar a impressão dos entrevistados sobre a relação entre movimentos sociais do campo e Estado, no período. 
Há que se ressalvar, contanto, que cerca de $40 \%$ das entrevistas foram feitas no segundo semestre de 2016, quando já concretizado o impeachment da Presidenta Dilma.

Quanto à percepção dos entrevistados na relação estabelecida entre os movimentos sociais e o Estado, a pesquisa buscou investigar como se processou tal relação com a ascensão do Governo Lula da Silva. Em relação a esta sondagem, percebeu-se que a compreensão dos que entendem ter havido um alinhamento entre a intervenção dos movimentos correspondeu a $47 \%$ da opinião dos entrevistados, conforme Gráfico 8.

No cenário captado pela pesquisa, é possível perceber, ainda, que houve um gradativo crescimento em relação à consciência e leitura política do fenômeno. Assim, desenhou-se um retrato de uma dupla insatisfação. De um lado, a frustração da expectativa ou da promessa de reforma agrária, no governo do Partido dos Trabalhadores. De outro, uma frustração em relação ao próprio apelo político e simbólico dos movimentos, quanto à importância da organização e mobilização. Em boa parte, isso explica as mobilizações mais pontuais, voltadas para um centro de interesse mais localizado, resultando, muitas vezes, em formas espontâneas e bastante localizadas de mobilização.

Gráfico 8 - Movimentos sociais e Governos populares (2003-2016)

\section{Movimentos sociais e Estado - formas de relação (2003-2016)}

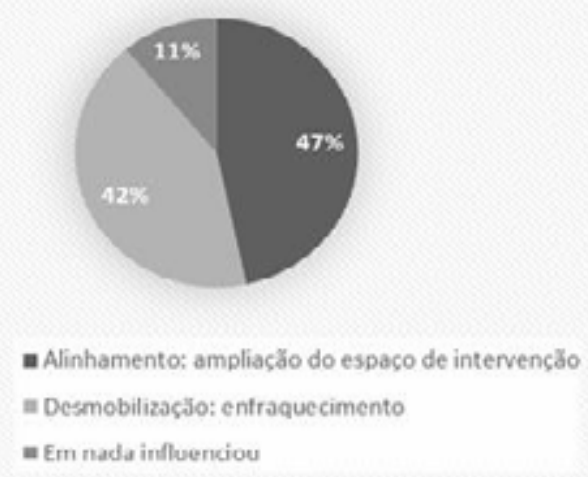

Fonte: Própria Autoria (adaptado) de Pesquisa de campo, 2016/2017 
Essa constatação de que o "alinhamento" significou, em grande parte, a "absorção" dos movimentos sociais, e não só igualmente das forças antagônicas, no aparato do Estado, é evidenciada por muitos analistas, que nomeiam tal fenômeno de "hegemonia às avessas". Destaque-se, aqui, a contribuição analítica de Francisco de Oliveira, Ruy Braga e Cibele Rizek (2010), que organizaram um evento e texto, sobre o assunto, sob várias perspectivas. $\mathrm{E}$ do que se trata a lógica da hegemonia às avessas? Nada mais do que consolidar uma situação na qual parte "dos de baixo" dirige o Estado pelo programa "dos de cima”, ou seja, a vitória política, intelectual e moral "dos de baixo" acaba fortalecendo, de forma dialética, a lógica da exploração, em benefício e privilégio dos de cima (Oliveira; Braga; Rizek, 2010, p. 8).

O curso pragmático dessa "absorção", ou nomeado também de "sequestro", dos movimentos sociais, outro resultado não provocaria a não ser um processo gradativo de desmobilização. De tal forma, se despolitizam as questões sociais, a desigualdade substantiva, que se transformam em meros problemas de administração. Por aí se desvela o "desaparecimento" de profundas e históricas questões sociais, como a questão agrária, da agenda política, no período. De certa forma, e esta é uma crítica bastante comum, ao considerar as questões sociais como questão de gestão, funcionalizam-se tais questões. Estas são transformadas, pois, em questão de gestão, incorporando outras narrativas, inclusive a dos "pactos pela governabilidade" e a questão das prioridades.

Adotaram-se, pois, os instrumentais necessários para que demandas subalternas, historicamente, fossem incorporadas. Assim, a legitimação se fazia acompanhar de práticas de "absorção" via incorporação de cargos no aparato do Estado, repasses para projetos cooperativos etc. Para Ruy Braga (2010), essa tal "subserviência inorgânica” acabou transformando-se em um oportuno consentimento ativo para muitos militantes sociais. É quando a narrativa para assegurar determinada posição se circunscreve no mesmo molde, antes combatido. Assim, em grande parte, os movimentos sociais se viram incorporados à burocracia estatal, integrados numa 
agenda alienígena, em nome de uma aparente e, portanto, inconsequente realização de bandeiras históricas dos próprios movimentos.

Em análise parecida, Rebecca Abers e Marisa Von Bülow (2011) detectam que essa lógica de incorporação de ativistas de movimentos sociais em cargos governamentais tem sido um dos pressupostos essenciais para uma necessária revisão da literatura sobre os movimentos sociais brasileiros. É preciso constatar, portanto, que alguns movimentos têm utilizado a instância (campo) do Estado como uma plataforma de onde se tornem tanto mais visíveis quanto mais eficazes as suas reivindicações (Abers; Von Bülow, 2011, p. 66). No entanto, há que se registrar que outros movimentos têm rejeitado, contundentemente, essa alternativa.

Aplicando essa análise ao cenário da pesquisa, uma das questões exploradas ressalta o "desencanto", a partir dessa lógica, de assujeitamento dos movimentos sociais em relação ao Estado. Ao indagar sobre os resultados efetivos atingidos, até então, pelos movimentos sociais, em relação às principais demandas, diante das alternativas, $48 \%$ responderam que tais reivindicações simplesmente ficaram paralisadas. Sobretudo em função do atendimento a novas demandas, principalmente burocráticas: atendimento de requisitos para viabilização de recursos destinados, levantamentos, cadastramentos, participação em instâncias deliberativas. Em sentido paralelo, 30\% informaram que, em relação aos pleitos dos movimentos sociais, recuaram, em razão do distanciamento dos movimentos de suas bases. Dos entrevistados, $12 \%$ admitiram que as demandas avançaram no resultado concreto, e 10\% informaram que tais demandas se descaracterizaram, sobretudo em razão de fatores estruturais, como o fortalecimento do agronegócio, no período de tais governos. 



\section{MOVIMENTOS SOCIAIS DO CAMPO E PROCESSOS PARTICIPATIVOS: RELAÇÕES EM MOVIMENTO}

Muitas e acaloradas discussões têm sido travadas, no plano da pesquisa e da análise, nesse campo das relações entre os movimentos sociais do campo e Estado. E, nesse sentido, as contribuições de Carter (2010), Palmeira (1994), Ondetti (2008), Neves (2017), para citar apenas alguns, têm aprofundado tais questões. Dessa forma, a perspectiva aqui trazida molda-se na abordagem exploratória do Incra, enquanto Estado, sua carga histórica, sua instrumentalidade, verbalizadas tanto nos discursos adotados por parte de seus servidores, quanto materializadas expressa ou tacitamente em suas ações e funções.

Partindo da realidade de que se trata de abordar e estudar um fenômeno humano, humano este que corporifica coletividades e instituições, outro não seria o caminho senão o de atentar-se para as dimensões históricas, processos de interação e relação, ideias, valores, normas de comportamento e hábitos, ali constituídos. Portanto, ainda que não se configure como uma pesquisa etnográfica, lança-se mão de instrumentais etnográficos para perceber como esse fenômeno se manifesta, localizado na fronteira dessa relação entre Sociedade e movimentos.

Há, sim, de certa forma, uma perspectiva discricionária, na interpretação dessa observação. No entanto, tal abordagem seguiu caminhos já percorridos, apontando sempre o específico da realidade de Rondônia. Não de forma exaustiva, mas ampara-se essa perspectiva em trabalhos já realizados (Le Tourneau; Bursztyn, 2010; Penna; Rosa, 2015; Almeida, 1989).

Em primeira mão, é importante constatar que não se trata de buscar compreender as interações ou conexões entre movimentos e Estado, à luz 
de mera generalização dicotômica, entre processos de institucionalização ${ }^{1}$ versus ação coletiva. No processo de elaboração e constituição de políticas públicas, há variáveis na forma de como se estabelecem e dinamizam essas interações e na forma como elas se operacionalizam, nem sempre fácil de perceber em leituras de primeira ordem. Assim, já se alerta para o risco de pensar a dinâmica relacional entre Sociedade-Estado, de forma prêt-à-porter, ou seja, nas explicações prontas, instituída e que, por vezes, encobrem mais que revelam.

Há que se pôr em destaque, ainda, o paradoxo traduzido nas recorrentes tentativas do próprio Estado brasileiro em cumprir ou "mitigar", nas formas programáticas, as promessas de democratização do Estado social, das garantias fundamentais projetadas na Constituição de 1988, mas em muito burladas no contexto subsequente. Tais contradições articulam-se no interior do Estado, variando conforme as condições e oportunidades políticas, nas quais as decisões são tomadas. Mas, também, essas formas de intervenção são incorporadas em um leque maior de possibilidades: contexto local, capacidade de sensibilização e mobilização de segmentos sociais, práticas políticas instrumentais etc.

Assim, a ação do Estado, materializada em seus agentes, vai se diversificando nessa arena de atuação e disputa. Vislumbra-se um conjunto heterogêneo de ações, envolvendo influências externas, relações consensuais, na forma de parcerias, coexistindo no mesmo processo e influenciando no modo de gestão. Assim, torna-se possível compreender e analisar o comportamento de atores políticos, as formas como as decisões são tomadas e o papel dos movimentos sociais, que se incorporam, voluntária ou automaticamente, ao processo.

\footnotetext{
${ }^{1}$ Esclarece-se que a perspectiva de leitura, à luz da pesquisa realizada, não se prende muito à discussão acerca da institucionalização dos movimentos sociais, enquanto elemento de ambiguidade ou contradição. Isso ocorre pelo fato de que o fenômeno observado se revela mais como espaço de mediação e, portanto, um lugar de tensão e de disputa. Reconhece-se, sim, que o fenômeno da institucionalização pode ocorrer e como de fato ocorreu, mas, em perspectiva relacional (Estado-movimentos sociais), representou, na pesquisa, a perspectiva dos movimentos sociais em negociar e interagir com o Estado. Ressalva-se, contanto, que há um leque maior de análises, que possam contemplar outros elementos. Trata-se, assim, de um processo em que a luta pelo espaço político leva ou potencializa, justamente, a politização e publicização das demandas tangidas pelos movimentos sociais do campo.
} 
A gramática dessas interações, portanto, exterioriza pluralidade e dinamismo. Define formas de integração, reelabora práticas de atuação, incorpora e ressignifica, inclusive em mudanças de perspectiva e de método. Por um lado, esse fenômeno estabelece a distância das diretrizes ortodoxas, que sistematizam as definições de tais práticas. Por outro lado, ao desvelar a fragilidade das perspectivas dualistas no trato interpretativo dessas questões, projeta a necessidade cada vez maior de incorporar elementos transdisciplinares em relação aos fenômenos políticos, demarcados nas ações coletivas.

Assim, a observação possibilitou perceber que as interações devem ser analisadas e valoradas no interior ou no ambiente das instituições, mas, também, nos espaços recriados, dentro dessa arena, na forma de diálogo, enfrentamento, pressão ou confirmação. Possibilitou compreender, ainda, que não se trata de uma interação entre sujeitos abstratos, mas, mesmo que em planos diversos, de atores concretos, com percepções distintas ou aproximadas, com interesses expressos ou simbólicos, e que assim constroem e reconstroem o sentido social da ação coletiva, enquanto ação política.

\subsection{O PROCESSO DE REDEMOCRATIZAÇÃO NO CONTEXTO DOS PROJETOS DE COLONIZAÇÃO}

Há um recorte temporal necessário que se faz importante apreender. $\mathrm{Na}$ perspectiva dos processos de colonização no Estado de Rondônia e nos impactos a respeito da participação dos movimentos sociais do campo em sua relação com o Estado, o contexto histórico foi fundamental. A década de 1960 representou, sobretudo em sua segunda metade, os arranjos do Estado (militarizado) com os empreendimentos da colonização privada. Os grandes projetos de colonização, concebidos à luz da "Operação Amazônia" (1966), se consubstanciariam na década de 1970, entrando em boa parte da década de 1980 (Souza, 1977).

A segunda metade da década de 1980 processa, no interior da sociedade brasileira, toda uma expectativa transformada em dinâmica de redemocratização. No país, a partir de 1985, grandes e articulados debates sobre temas da reforma constituinte são incentivados. Na Amazônia, mais 
ao noroeste, povos e comunidades tradicionais se articulam em torno de um emblemático movimento por reconhecimento, na perspectiva territorial de suas demandas, consolidado no termo "Povos da Floresta".

A efervescência político-social foi causada, no contexto do movimento migracional (anos 1970 e 1980), à luz de todo o debate da redemocratização e da elaboração constitucional. A narrativa constituinte atinge também a "questão agrária", em seus novos e reeditados desafios, fazendo emergir a necessidade de um Programa Nacional de Reforma Agrária (PNRA).

No contexto amazônico, ocorre, na década de 1980, o agravamento dos conflitos pela posse da terra. Tais conflitos são tratados, antes de mais nada, como questão política, na perspectiva dos governos militares, à sombra ainda de todo o contexto de debate e articulação da época do golpe civil-militar (1964). Ao leste amazônico, a questão fundiária ganha contornos de estratégia geopolítica e são criados o Ministério Extraordinário para Assuntos Fundiários (MEAF, 1982)2 , o Grupo Executivo de Terras do Araguaia/Tocantins (GETAT, 1980) e o Grupo Executivo Baixo Amazonas (GEBAM, 1980).

$\mathrm{Na}$ outra ponta da Amazônia (Noroeste), para atender as diretrizes do Programa de Integração Nacional bem como os pressupostos dos programas de colonização, a direção política dos órgãos públicos estava a cargo dos militares, ou por eles indicada. Em Rondônia, desde 1968, chefiava o Órgão de terras o Capitão Silvio Gonçalves Farias, responsável tanto pelo direcionamento da Política de Colonização dirigida, quanto pelo repasse de grandes áreas de terras a empresários e empresas, via contratos de licitação.

Em Rondônia, é igualmente na década de 1980 que diversas e distintas formas de resistência, por parte de grupos de camponeses, esquecidos ou traídos pelos projetos de colonização no Estado, começam a se constituir, organizando-se, seja através de resistências pontuais, via enfrentamentos diretos, seja através da organização de movimentos sociais, apoiados, em grande parte, pela Igreja Católica local.

\footnotetext{
${ }^{2}$ Para José Gomes da Silva, o MEF foi constituído mais para manter o controle militar sobre as questões de terra, que se agravaram a partir dos anos de 1970, e ainda para resolver um problema de agenda de promoções do Exército (Silva, 1987).
} 
O programa governamental de integração e colonização da Amazônia foi acompanhado e motivado por incentivos fiscais, incidindo, assim, em um dinamismo migratório sem precedentes. Isso precipitou um aumento e agravamento de conflitos agrários na Amazônia, paradoxalmente associados ao chamado "milagre brasileiro", no início do período militar. A ideia veiculada pelo paradigma desenvolvimentista havia, na verdade, sido planejada estrategicamente na chamada Operação Amazônia, em 1966, e a base do modelo de desenvolvimento agrário para a região direcionava para a pecuária em larga escala (Hall, 1989; Costa, 2012).

Mesmo diante de evidentes equívocos (como a colonização ao longo da Transamazônica), o governo realizou muitos investimentos, associado, por sua vez, ao capital transnacional, sobretudo do Banco Mundial. Em regra, o obstinado projeto se efetivaria sob os ditames e moldura da "modernização conservadora", na qual fluem e se solidificam grandes empresas, o capital estrangeiro e famílias latifundiárias na Amazônia. Pela lógica da colonização, como negação da reforma agrária, o latifúndio improdutivo se transformaria em empresa moderna. Grandes áreas de domínio público seriam transferidas ou destinadas a empreendimentos agropecuários privados e, assim, modernizaria também as relações técnicas sem que preciso fosse alterar as relações patrimoniais no campo brasileiro (Costa, 1992, p. 13).

Garantia-se, assim, tanto por parte dos altos incentivos fiscais, quanto pela opção clara de não realização de uma política agrária, o fortalecimento de um modelo de concentração da propriedade, vinculado sempre aos fatores locais constitutivos do poder político e econômico de uma determinada base social, que evidentemente significasse, politicamente, a sustentação do regime (Martins, 1995).

A opção pela pecuária ou pelo incentivo aos estabelecimentos agropecuários, na década de 1970, conjugava uma lógica que incidia, no caso da implementação de grandes empreendimentos agropecuários, em potencialização da entrada do Grande capital na região. A grande empresa pecuária torna-se peça fundamental para a análise dos processos de colonização na Amazônia. Importante ressaltar que esse ramo econômico não só traduz o âmbito de inserção e acúmulo do capital, na forma de projeto econômico, 
como também se materializa como instrumental político fundamental e programático, configurando, assim, no contexto local, as pretensões governamentais de projeto de desenvolvimento.

Rondônia, em abordagem específica, desenvolveu-se inicialmente sob o discurso da "fronteira agrícola", mote bussolar do projeto de colonização, seja privado, seja público. No entanto, a coexistência de grandes áreas de terras, assenhoradas pela grilagem e imunizadas pelas concessões de terras públicas, acenava para o ideário da empresa rural, como projeto fundiário estruturante. Essa orientação, portanto, como já visto, não só de cunho econômico, mas eminentemente político, converteria a "frente agrícola" em "frente agropecuária".

Reconstituía-se, assim, a montagem das "velhas" estruturas nas "novas regiões”, potencializando, de forma funcional, extremamente efetiva, a acumulação capitalista em territórios de colonização dirigida pelo Estado. De tal forma, pela via da conveniência econômica, a gestão política se estabelece tanto nos termos do patronato rural proprietário, quanto nos projetos políticos da ditadura. Sem condições, incentivos e recursos, a "frente agrícola" padece de um (pre)destino manifesto: uma vez que não atrai mercados, demonstra-se inapropriada.

Face a esse conjunto de inadequações, a modernização conduzida pela ditadura orientava-se pela assertiva: 'contenham-se as estruturas camponesas que conduzem o desenvolvimento extensivo da agricultura e poder-se-á intensificar com maior rapidez a produção organizada em moldes capitalistas'. Para que tal objetivo fosse atingido, jogou-se o grande capital 'na fronteira', colocando, assim, em questão o principal fator que fazia a produção familiar seu fundamento: o acesso à terra (Costa, 2012, p. 53).

José Gomes da Silva (1987), um dos mais importantes analistas do problema agrário brasileiro, do período militar em diante, presenciou e refletiu sobre o impacto da questão agrária, enquanto política de Estado. Como fazia parte do Grupo de Trabalho de Regulamentação do Estatuto da Terra (GRET) e, posteriormente, do grupo constituído para a elaboração do primeiro Plano Nacional de Reforma Agrária (PNRA), percebeu de perto 
o drama da questão agrária brasileira. Na sua percepção, a questão agrária, sob o imbróglio de uma oligarquia rural e patrimonialista, fez "cair por terra" qualquer possibilidade suscitada pelo próprio Estatuto da Terra de 1964.

Em outro momento nacional importante, o da Assembleia Nacional Constituinte, testemunhou o drama e todos os impasses em relação ao que estava sendo posto no texto constitucional acerca do tema. Resume o resultado de todo o embate e mobilização da própria sociedade acerca da relevância e importância do tema, ao concluir que se trata de um verdadeiro problema institucional, alvejado por forças e interesses conjugados, doutrinariamente articulados, decidindo desde sempre pela não-realização ou paralisação da reforma agrária no país (Silva, 1987).

É nesse panorama que, paradoxalmente, conjuga-se a "volta da democracia" com a polarização de setores ultraconservadores, patronais, no cenário do campo brasileiro. Surge a União Democrática Ruralista (UDR), com diretrizes programáticas de extremismo reaceso, e com práticas radicalmente antidemocráticas e anticonstitucionais.

Em Rondônia, com o suposto fracasso das atividades da colonização particular, o modelo, agora, em plena década de 1980, é o da colonização oficial dirigida, a cargo do Incra. Mesmo se tratando de colonização pública, tal proposta contará e se constituirá sempre com reserva ou "estoques de terras" a serem transferidas para o domínio privado, ou ao empresariado rural. De tal forma, há lugar, sim, na Amazônia, para que a oligarquia agrária, sobretudo do Sudoeste e Sul do Brasil, possa angariar vultosas áreas de terras, sob o manto legal e administrativo do Estado brasileiro. No caso específico de Rondônia, o "arranjo” se deu pelas licitações, a custo mínimo. Conforme a narrativa vídeo-documental de Vincent Carelli (2009), já abordada neste livro, "o governo gastou mais demarcando os lotes (de 2.000 hectares) do que cobrava pelas terras”. 


\subsection{PRESSUPOSTOS DA RELAÇÃO ESTADO- MOVIMENTOS SOCIAIS DO CAMPO: CONDICIONANTES E VARIÁVEIS}

Uma das conclusões da pesquisa qualitativo-exploratória realizada reage contra a possibilidade de generalização ou padronização acerca da controversa relação Estado-sociedade. Isso resulta muito claro nas posições que tanto os servidores públicos ${ }^{3}$, quanto os integrantes dos movimentos sociais enunciam. A ideia inicial foi justamente buscar compreender a forma dessa relação entre movimentos sociais e Estado, os efeitos da atuação desses movimentos em relação às políticas públicas e os diversos níveis desta interação. Constatou-se que a compreensão dessas políticas supõe um olhar mais atento sobre as relações e as conexões estabelecidas.

Tanto em relação aos servidores quanto aos integrantes dos movimentos sociais do campo, chamados ora de "beneficiários", ora de "clientes da reforma agrária", ora de "parceiros", todos sofrem, nesses "empréstimos mútuos", influências e impactos que interferem na implementação das políticas públicas, sobretudo de reforma agrária.

Uma ampla gama de atores é incorporada nesse processo, formando uma rede complexa. Trata-se de um campo que envolve Partidos políticos, movimentos sociais, o INCRA, órgãos de controle, Ministério Público Federal, Ouvidoria Agrária Nacional, prefeituras municipais, associações, advogados etc. Essa rede materializa-se em diversas conexões, que afetam ou interferem em todos os atores em cena.

Por outro lado, uma teia de procedimentos nessas relações dá conta dessa complexidade nas mais diversas formas e rotinas. Inclui a interferência

\footnotetext{
${ }^{3}$ Trata-se de agentes públicos concursados ou nomeados (cargos de confiança/políticos), numa gama ampliada de funções: chefia (gabinete), divisões técnicas, atendimento e protocolo, arquivo e documentos, entre outras. Para a pesquisa, optou-se, em primeiro lugar, por coleta qualitativa acerca dos temas vinculados à questão central: relação com os movimentos sociais, repertórios utilizados, avanços e limites da política agrária, modos de tratamento e relações com lideranças e "beneficiários-clientes", politização da Autarquia, entre outros. Não houve seletividade no processo de contato ou escolha de entrevistados, baseando-se mais em critérios de oportunidade e tempo. Além de contatos informais, anotações, contou-se também com entrevistas gravadas e operacionalizadas por meio eletrônico. Analisaram-se ainda, documentos disponibilizados e relatórios de reuniões, audiências e intervenções em eventos públicos, como seminários, simpósios etc.
} 
de partidos e dos próprios movimentos, enquadra-se na pressão dos processos de controle, estipula-se sob a forma de convênios. Por vezes, tais convênios/acordos são mediados por representações dos beneficiários, por vezes, instrumentalizados por interesses localizados.

Assim, o Estado que se manifesta através de seus Órgãos, no caso do Incra, reproduz seu sentido e sua função, constituindo-se como ator-rede, na complexidade dessas relações. Isso estabelecido como pressuposto, por si só descarta o imediatismo da análise enquadrada tão somente nos esquemas de relação Estado-sociedade civil, que, por esse ângulo, seria insuficiente para a compreensão dessas múltiplas relações e seus efeitos.

Conforme assinala Becker (1990, p. 40), este Estado é o próprio Incra, com sua política institucionalizada, orientando (dirigindo) as formas de ocupação e controlando, por diversas formas, os “movimentos migratórios”. Para tanto, é efetivo em impor a monopolização das terras, sobretudo por parte de grandes imobiliárias, latifundiários, fazendeiros, sob a chancela disciplinar e jurídica do Estatuto da terra, ou Estatuto da empresa rural e da colonização dirigida. Ianni (1979) vai se referir a essa estratégia de Estado como "colonização e contrarreforma agrária na Amazônia", onde seja possível "dar um pouco de terra para que nenhuma terra seja dada" (Ianni, 1979, p. 127).

No contexto dessas ponderações, há que clivar a questão, também complexa, de perceber a ação política nos processos democráticos em termos de confronto-consenso. Sabe-se que, nas últimas décadas, sobretudo a partir de 1990, tem ganhado proeminência o discurso do consenso, por vezes imiscuído na lógica da passividade. Tal fenômeno tem sido tratado como resultado inexorável de uma racionalidade liberal inconteste. Em ambos os casos, desloca-se o lugar das narrativas, então centradas na ideia de dominação, mas também impacta as interfaces plurais e pluriperspectivas do próprio liberalismo.

Em terras brasileiras, não há como ilusoriamente descartar a histórica e colonial performance da questão agrária, como problema do século XIX não resolvido no século XX e amplificado e repaginado em pleno século XXI. Essa abordagem acusa as assimetrias sociais decorrentes dessa 
constituição histórica, desafiando textos e contextos, inclusive aqueles que, em particular, associam à ideia de liberdade e democracia a ideia de igualdade, para além do seu apelo formal. A questão que se impõe é se há alguma autêntica possibilidade de construir consensos democráticos e participativos, aceitando que grupos despossuídos, desterrados, existam, como sinal evidente e manifesto de uma desigualdade jurídica e política ambivalente.

Igual, ou mais que em qualquer outro campo, é na realidade agrária que o litígio se constitui, seja como resultado circunstancial das relações assimétricas atuais, seja na forma de perpetuação de uma estrutura histórico-colonial. Assim, o contencioso assinala essa perspectiva de disputa, ressituando o antagonismo entre dominantes e dominados. Tal antagonismo pode até, e inclusive, ser invisibilizado, no entanto, não há recurso mágico ou artimanha retórica que o transcenda.

Toda a análise da luta política deve ter como fundamento as determinantes econômicas e sociais da divisão do trabalho político, para não ser levada a naturalizar os mecanismos sociais que produzem e reproduzem a separação entre os 'agentes politicamente ativos' e os 'agentes politicamente passivos' e a constituir em leis eternas as regularidades históricas válidas nos limites de um estado determinado da estrutura da distribuição do capital (Bourdieu, 1989, p. 163).

A unanimidade, muitas vezes reportada sob a moldura da sociabilidade, da pacificação, dos consensos, nubla a compreensão do fenômeno político que envolve de forma performática os movimentos sociais. Em específico, no caso dos movimentos sociais do campo, não foram poucas as vezes, em nossa recente história, que se tentou aniquilar o dissenso ou o conflito lançando mão, em muito, do aparelho de dominação política.

De igual forma, os modelos de ajuste econômico, sobretudo aqueles redimensionados pelo patrimonialismo, incidem na insistência da reprimarização da economia ou mercantilização dos bens da natureza, instrumentalizados por múltiplas formas extrativistas (mineração, petróleo, energia, monocultivos, exploração de madeira). Esse modelo provocou e provoca, no cenário amazônico, intensas pressões sobre os territórios dos 
povos e comunidades tradicionais, suscitando numerosos conflitos, tanto sociais (luta pelo acesso à terra), como socioambientais e territoriais (reconhecimento, pertencimento e defesa dos territórios).

Trata-se de um campo de conflito e disputa que põe em cena processos de desterritorialização e reterritorialização, enfrentamento dos modelos de agroprodução, nos quais os atores ou sujeitos envolvidos se relacionam, se confrontam, e os processos de disputa se configuram e se constituem. Assim, o conflito comparece como categoria estruturante da narrativa política e pauta, nas relações estabelecidas, o sentido dessa conflitualidade.

Para Bourdieu, buscando entender os entremeios do campo político, nada teria sentido fora do campo das relações. E assim ocorre como se a distribuição de posições políticas resultasse em uma distribuição de papéis, onde cada ator constitui-se em sua posição pela concorrência que ameaça. Tais atores, enfim, tendem a organizar-se na oposição entre dois polos, sendo que, no interior desses polos, constituem-se, igualmente, verdadeiros campos. $\mathrm{O}$ antagonismo, a concorrência e a oposição que se materializa nessas relações, estabelece as condições de sentido e compreensão. Completa Bourdieu que "nada, nem nas instituições ou nos agentes, nem nos atos ou nos discursos que eles produzem, tem sentido senão relacionalmente, por meio do jogo das oposições e das distinções” (Bourdieu, 1989, p. 179).

Em Rondônia, o dimensionamento ideológico do conflito social revela-se pouco filtrado, na perspectiva da relação entre agentes públicos e lideranças dos movimentos sociais. $\mathrm{Na}$ esfera institucional da autarquia responsável pela questão agrária, o caráter de política pública se sobrepõe na instância do debate público, das reuniões e audiências programadas. Nesse sentido, a "tensão social” gerada nessas ocasiões é absorvida pela dinâmica rotineira do órgão público, suas questões procedimentais, burocráticas e técnicas. É no campo específico da análise do conflito em si, sobretudo no âmbito da Comissão Nacional de Combate à Violência no campo (CNVC), que a questão é reproposta no campo do lícito-ilícito (Dimensão penal-criminal) e onde se adota, nos meios vinculados à política de segurança, por parte dos agentes do Estado, o caráter ideológico, que ganha publicidade nas análises governamentais. 
A incidência dessa realidade localizada no campo fronteiriço da relação entre movimentos sociais do campo e Estado perpassa por várias dimensões da conflitualidade. Tal conflitualidade, no entanto, não se reduz apenas ao enfrentamento com o Estado, uma vez que é também um conflito de classe. Além do mais, o enfrentamento é apenas um momento (agudo) do conflito, localizado no âmbito interno no processo de desenvolvimento imposto, na sua forma de organização social e territorial. O cenário visível desse enfrentamento foi retratado pelos dados da CPT, em relação ao ano de 2016, com a seguinte estatística:

Tabela 7 - Dados da violência contra a pessoa - Rondônia/2016

\begin{tabular}{|l|c|}
\hline \multicolumn{1}{|c|}{ Violência contra a pessoa em 2016 } \\
\hline No de conflitos & 172 \\
\hline Assassinatos & 21 \\
\hline Tentativas de assassinato & 10 \\
\hline Ameaçados de morte & 40 \\
\hline Agredidos fisicamente & 141 \\
\hline Presos & 88 \\
\hline Detidos ou ameaçados de prisão & 121 \\
\hline
\end{tabular}

Fonte: CPT, 2017

O conflito, aqui mapeado, retrata a materialização da violência sofrida pelos trabalhadores rurais, sejam eles sem-terra, posseiros, povos tradicionais etc. Tal violência, via de regra, é uma violência, sobretudo, promovida ou agenciada por grandes interesses patrimoniais (grandes fazendeiros, grileiros, madeireiros). Trata-se de repressão privada, estipulada por contrato, utilizando-se de milícias paramilitares, crimes de pistolagem etc. No entanto, atenta-se para o fato da participação do Estado, cada vez mais incisiva, como forma de repressão institucionalizada.

$\mathrm{Na}$ relação Estado-movimentos sociais, no campo institucional, a conflitualidade ganha outros contornos que, no entanto, precisam ser apreendidos no conjunto da questão da Política agrária. Em cenários mais recentes, a conflitualidade avança para além dos elementos que circunstanciam 
a violência física; no campo dos enfrentamentos, também há a violência simbólica. Essa violência simbólica é posta em evidência nos retrocessos legislativos, estrategicamente calculados, e na verticalização da judicialização da questão da terra e dos movimentos sociais do campo. Assim, enquanto dispositivo de poder, lança mão o Estado de seu aparato, seja no campo policial, seja no campo judicial, utilizando-se de formas sofisticadas e facilmente legitimadas para empreender a contenção do conflito.

\subsection{A PERCEPÇÃO DESDE DENTRO: O ESTADO AUTOCOMPREENDIDO E A PERCEPÇÃO DO CONFLITO}

$\mathrm{Na}$ busca em compreender como - e em que bases - se configura a relação entre os agentes do Estado e a sociedade (cliente), perpassa uma compreensão na qual se mesclam inúmeras variáveis. São vetores que demarcam, mas também permeiam essa relação: forma do vínculo do servidor (contratado/nomeado), contexto histórico político envolvente (Ditadura/ Redemocratização), graus de afinidade, trajetória política, vínculos religiosos etc. Pode-se dizer que a identidade deste Estado transmuta-se no seu agente, é por ele incorporado ou nele se incorpora.

Quando a questão é deslocada para o âmbito interno das disputas políticas institucionais, é possível perceber e identificar, no caso pesquisado, pelo menos quatro questões centrais que envolvem controvérsias e disputas acerca de diferentes temáticas: 1) o tempo de casa do servidor e sua compreensão e visão; 2) a relação-interferência partidária junto ao Incra; 3) a relação intrínseca com os movimentos sociais; 4) as relações intrínsecas e o jogo burocrático na perspectiva do patronato rural institucionalizado.

Em um cenário de confronto político, onde as situações de disputa são evidenciadas, a percepção desse conflito reclama por uma racionalidade, que se operacionaliza nos argumentos e opiniões, ajeitadas ou não, na forma de justificativas. $\mathrm{O}$ alicerce da legalidade, como fundamento das ações de Estado, tem sido intensa e recorrentemente utilizado nesse sentido 4 .

\footnotetext{
${ }^{4}$ A esse respeito, veja-se a própria compreensão da região, como "Amazônia Legal”, assim como a criação de programas de regularização fundiária, entendido como "Programa Terra Legal".
} 
Em relação à compreensão da questão agrária, função do Incra, e a sua relação com os movimentos sociais, o item "tempo de casa do servidor" demarca uma questão primordial sobre como se processam as disputas de visão política e da prática do cotidiano, no órgão pesquisado. No caso do Incra, os servidores contratados antes da década de 1990, ou então aqueles que se incorporaram ao órgão no período militar, refletem, em regra, um posicionamento diferenciado quanto ao papel do Incra, do Estado e dos próprios movimentos sociais.

A missão do Incra era colonizar a Amazônia, sempre de olho no que o fantasma do comunismo podia representar. Mormente, quando corriam rumores que a semente de "Che" Guevara vingava na vizinha Bolívia. Um militar deveria assumir o posto de coordenador. Assis Canuto continuaria prestigiado, mas seria remanejado para o vizinho Estado de Rondônia. Para o Alto Comando das Forças Armadas, a região da faixa de fronteira não poderia ficar à solta. E não era por acaso que no sul do Pará, o Grupo Executivo das Terras do Araguaia e Tocantins (Getat), braço militar da instituição, dava as cartas. $\mathrm{O}$ momento exigia que o comando das ações do órgão na Amazônia ocidental fosse entregue a alguém que tivesse a cara e o espírito nacionalistas do momento (Nascimento, 2006, p. 136).

A dinâmica funcional se caracteriza mais pela competência e capacidade em administrar tal política nas condições desafiadoras do contexto do "desbravamento da Amazônia" que no nível técnico e profissional demandado de um servidor atual, concursado. Jean Hébette (2004) esclarece que, na perspectiva da colonização, sempre na lógica do "vazio demográfico", o Incra foi investido de enormes poderes, inclusive se encarregando de funções públicas relacionadas aos colonos, tornando-se, enfim, um Estado dentro do Estado.

Percebe-se, em primeiro plano, o protagonismo do Incra como Estado, em dar efetividade à lógica da colonização dirigida, como projeto do governo militar à época, na década de 1970. O papel evidenciado do órgão cumpriu uma agenda elaborada sob a sistematização estrutural e ideológica 
do Programa de Integração Nacional, de 1970. A política de Reforma agrária, como instrumento e função do Órgão, será redimensionada no contexto da redemocratização, entre o final dos anos 1980 e o início dos anos 1990. Essa distinção conceitual e temporal é fundamental, sobretudo para compreender a atuação do Órgão, na atualidade (CASTRO, 2013).

Essa distinção aparece claramente demarcada no primeiro Plano Nacional de Reforma Agrária. Distinguiam-se os processos do período da colonização, substantivamente cumprindo uma função de povoamento e concessões de terras públicas, dos programas de assentamento, como projeto técnico, contando com a participação direta dos beneficiários, sobretudo no que se refere às decisões sobre as formas de posse e uso das terras (Decreto $\mathrm{n}^{\text {o }}$ 91.766, de 10 de outubro de 1985).

Em geral, os servidores da época se autocompreendem como pioneiros, agindo com destemor e cumprindo uma função estatal imprescindível, visto que a colonização da Amazônia era questão prioritária para o governo militar. Os executores do Incra ou eram alinhados aos militares ou eram egressos do próprio oficialato, como o foi, no caso de Rondônia, executor do Incra, o Capitão Silvio de Faria, ligado ao Conselho de Segurança Nacional (SOUZA, 2011).

Em observação de campo dos contratados do Incra, de especial maneira aqueles servidores que remanescem desde o tempo da militarização do Órgão, é recorrente ouvir o relato sobre a "organização militar e sua eficiência" na década de 1970 e 1980. A percepção, igualmente, sobre os movimentos sociais do campo em sua relação com o órgão, também se distingue. Conforme esses funcionários, "não se falava em movimentos sociais naquela época".

Em relação à forma de atuação, "ninguém falava em invasão de fazenda e muito menos em invasão do Incra”. Em estudo etnográfico realizado por pesquisadora, na Superintendência Regional de Marabá, conforme depoimento relatado, a funcionalidade do Órgão evidenciava-se por outro papel. Conforme testemunho de Servidor do Incra, lotado no Órgão, desde 1983: 
O público vinha aqui na Unidade. Nessa época dos militares, do GETAT, a ideia era dar celeridade para a emissão de títulos, era muito célere a entrega de títulos. Eu acho que com a chegada do INCRA tanto a Unidade como a SR(27) começaram a fazer aquele papel, aquela coisa de assistencialismo ao colono (Castro, 2013. p. 141).

Percebe-se em tais narrativas, que a lógica do "tempo de casa” é substancial para demarcar o papel do Incra. O "Incra de antes", um órgão muito mais aparelhado de recursos, com sua agenda pautada em efetivar uma política estruturante do Estado brasileiro: o programa dirigido de colonização. O "grupo dos antigos" representava e representa os servidores do tempo da militarização, "do tempo do GETAT", com sua visão de estratégia política evidenciada como um dos principais braços do Estado, desenvolvendo um trabalho pioneiro, cumprindo quase de forma "salvacionista" as sagradas funções do Programa de Integração Nacional.

Em relação aos "servidores novos", a partir de 2004 e 2005, uma primeira questão que sobressai é a compreensão acerca da "grande demanda de trabalho" associada à constatação de que o Incra não teria "estrutura para acompanhar tal demanda”. Esses funcionários constatam assim a amplitude da questão agrária, entendida sistemicamente como um processo, de contornos muito mais técnicos que políticos. Um dos entrevistados aborda, nos efeitos, nas causas e nas motivações, a dinâmica de tal processo: "Somos contratados para atender um grande número de atribuições, sem preparo devido, tendo que enfrentar, inclusive todas as dificuldades de adaptação e ambientação. Dá para perceber que há, de forma clara, uma intenção de sucatear e desmantelar o Incra, como órgão responsável pela política agrária”. (Servidor no Incra desde 2004).

Ponto recorrente, essa constatação de falta de estrutura e manutenção sofrida pelo Órgão é entendida, sobretudo por parte dos "servidores novos”, como um descaso em relação ao resultado final da política de reforma agrária. Nesse sentido, a fala de um dos entrevistados, sistematiza essa percepção: "Parece cada vez mais claro, e isso pode ser percebido no desgaste e na falta de estrutura de trabalho, que o governo federal tem 
uma intenção clara que é a de acabar com o Incra”. (Servidor no Incra desde 2004). Outros, no entanto, vão além, ao comparar os investimentos destinados ao Incra com os investimentos e os recursos destinados ao Ministério da Agricultura, Pecuária e Abastecimento (MAPA), inclusive em relação à equiparação salarial. Resta claro, conforme alguns servidores, uma oposição baseada em uma preferência, "do agronegócio sobre a agricultura familiar".

Nessa linha de argumentação, que reflete uma heterogeneidade de percepção e mesmo da forma como se autocompreendem, há no âmbito da Superintendência Regional do Incra, em Rondônia (SR-17), alinhamentos nítidos acerca do papel do Órgão em relação aos grandes proprietários e aos pequenos agricultores.

Como, no caso específico de Rondônia, a colonização privada precedeu a pública, constata-se que, em vários casos, isso se deu em razão do alinhamento de interesses particulares com os governos militares da época. São os casos como o da Imobiliária e Colonizadora Calama, a Colonizadora Itaporanga etc. que ilustram bem essa análise. Remanesce, ainda hoje, no Órgão, servidores que assumem claramente um posicionamento em favor de regularização de grandes imóveis públicos a empreendimentos privados, de oposição a ações administrativas e judiciais de retomadas de grandes áreas, concedidas a particulares sob condição resolutiva e comprovadamente inadimplentes etc.

Contudo, há igualmente um grupo de funcionários que se autorretratam como "servidores da reforma agrária", muitos militantes e favoráveis às bandeiras dos movimentos sociais, assumidamente. Essa oposição sinaliza, por sua vez, também, um alinhamento político, estabelecido no período da chamada redemocratização, incluindo aí todo o debate em torno da questão agrária constituinte, suas contradições e "possibilidades”.

E mais, à luz dessa chave de observação, no contexto em que, não raro, tramitam "acusações mútuas”, é possível constatar um "recorte geracional" na força e na forma de trabalho do Incra. A dicotomia que se estabelece entre os "antigos" e os "novos" evidencia-se, não só pela percepção do próprio papel do Órgão e de seus agentes, mas enuncia-se também na linguagem 
utilizada. Em relação aos beneficiários do Programa de Reforma agrária, os "antigos", os percebem, como "colonos" ou "clientes". Já para os "novos servidores", são "agricultores, trabalhadores rurais, assentados e beneficiários".

Outra questão a ser posta é justamente a da influência política no âmbito interno do Órgão. Ocorre que, no passado, a ingerência política não se fazia tão presente no Incra. A ressalvar a diferença de contexto e de regime, já que o Órgão cumpria, na região, papel preponderante da política de Estado. Conforme as narrativas dos servidores, a presença da política, sobretudo em sua tangência partidária, compõe o cotidiano da instituição. No entanto, admitem que também a interferência política dos movimentos sociais influencia as ações do Órgão.

Ocorre que, na atualidade, conforme os acordos e ajustes de composição partidária, são as forças políticas locais, atreladas ao partido da situação, que indicam cargos de chefia no Órgão. Isso vale para a função de superintendente e cargos como chefia de gabinete e ouvidor agrário regional. Essa conexão incide diretamente no direcionamento político das ações da superintendência e atravessa as estruturas do Órgão de diversas formas e em distintas circunstâncias. Assim o foi recentemente, nos dois períodos do governo Lula (2003 e 2010), quando os indicados a superintendente e alguns cargos de chefia eram egressos de filiados ao partido da situação e, posteriormente, nos governos Dilma/Temer, indicados alinhados ao maior partido que dava sustentação ao governo, o MDB.

Essa característica que permeia a estrutura das superintendências regionais aponta outros liames, significativos no plano das controvérsias e conflitos internos no órgão. Para os "servidores da casa", invariavelmente a presença desses "servidores de fora”, ou "servidores políticos" manifesta um aspecto crítico negativo, uma vez que esses "servidores nomeados politicamente" acabam por fazer um "uso político partidário e eleitoreiro" tanto da função, quanto do órgão.

Outro aspecto apreendido, na observação qualitativo-exploratória, diz respeito à distinção entre a atuação "técnica" e a atuação "política". Para boa parte dos funcionários da Autarquia, sobretudo os mais novos, a dimensão técnica refere-se mais à natureza do órgão, "uma pessoa da casa 
acaba demonstrando mais cuidado, mais conhecimento e maior responsabilidade" no seu campo ou área de atuação. Conforme a afirmação de um servidor, concursado, no Incra desde o ano de 2005: "eu acho que uma pessoa que atua no plano político aqui, acaba não fazendo um bom trabalho. Se a pessoa pauta uma carreira política no Incra, esta preocupação acaba comprometendo a qualidade do trabalho e de sua função junto ao órgão”.

\subsection{CONEXÕES PARTICIPATIVAS ENTRE ESTADO E MOVIMENTOS: DISPUTAS E ARRANJOS NUM NOVO "ESPAÇO PÚBLICO"}

Via de regra, é possível constatar, por parte das lideranças dos movimentos sociais do campo, a ideia de que é essencial levar e manter a discussão sobre a demanda de tais movimentos no espaço público do debate. Isso implica repropor outras formas de mediação, no caso, ocupando a instância na instituição estatal. Assim, diminuir a distância entre o Estado provedor e o possível "beneficiário" implicaria, por parte dos movimentos sociais do campo, verticalizar as formas de atuação, sobretudo em tempos de correntes adversas, ou mesmo, pela inação do próprio Estado.

Nesse contexto, entra em cena todo um repertório de ação articulada, por parte das lideranças dos movimentos sociais, envolvendo uma teia de relações com agentes públicos (representantes do Estado), sob o impacto de contextos e influências externas, questões conjunturais, de viés político, ou mesmo de contextos locais, que reforcem - expressa ou simbolicamente - a intenção ativa e reativa dos referidos movimentos.

Nesse sentido, captou-se como reveladora a forma como os "servidores”, ou seja, o Estado, percebe a ação e a relação do órgão com os movimentos sociais do campo. O ponto de embate gira em torno das diversas formas dessa relação, sobretudo quanto aos efeitos na execução das políticas públicas de reforma agrária. Em regra, tanto os funcionários quanto as lideranças utilizam o conceito de "parceria" ao fazerem referência a essa relação entre movimentos sociais e Estado/Incra. Na prática, contanto, essa relação de parceria ganha diferentes sentidos e articulações. 
Um desses sentidos traduz-se na forma de "pressão" exercida pelos movimentos sociais, caracterizada pela "ocupação" da sede do Incra e Unidades Avançadas. O que se objetiva, claramente, é estabelecer determinadas prioridades, seja em termos das demandas por retomadas de terras públicas, seja por regularização fundiária. Pode ser, ainda, referindo à ampliação ou efetivação das políticas de crédito, agendamento de ações prioritárias ou emergenciais etc. De qualquer forma, tais demandas são incorporadas, na estratégia da ocupação, como evento político que influencia e mesmo altera a rotina de trabalho dos servidores.

Há, em regra, todo um ritual que vai do agendamento e oferta de pauta, convocação de funcionários específicos da área, hierarquia de demandas, conforme a situação emergencial. Os compromissos serão lavrados em ata, como meio de formalização de compromissos. Em tudo, assume tal repertório, por parte dos movimentos sociais, uma forma de protesto, mas também de pressão.

Não é unânime a opinião acerca dessas intervenções, por parte dos servidores. Em regra, aqueles mais antigos ressaltam o aspecto negativo da interrupção do trabalho, a "desordem" provocada, mas reconhecem o aspecto da "parceria", quando tais mobilizações resultam, por exemplo, no acréscimo orçamentário.

A nominação de "relação de parceria", não raras vezes, também é assumida pelas lideranças dos movimentos sociais. Os contatos que caracterizam essa aproximação se efetivam na rotina e cotidianidade de reuniões, na identificação das demandas por parte dos servidores, nas visitas destes nas áreas, em geral acompanhados pelas lideranças dos movimentos sociais. Esses vínculos, inclusive, caracterizam-se por uma certa familiaridade, como em conversas telefônicas, instrumento este, inclusive, muito utilizado para um contato direto entre as lideranças e os servidores, incluindo os cargos de superintendente e cargos de chefia. É possível identificar que tal 
proximidade foi de certa forma melhor constituída e aperfeiçoada, a partir da perspectiva de atuação da Ouvidoria Agrária Nacional e Regional 5 .

Por parte dos agentes públicos vinculados à Ouvidoria, a questão do levantamento das famílias, assim como o controle do acampamento, é, em geral, um papel do movimento por meio de suas lideranças. Dessa forma, a lista das famílias, para fins de Cadastro no sistema (SIPRA), nos termos dos critérios formais do órgão, é papel incorporado pelas lideranças do movimento. Inclui-se, nesse caso, a negociação acerca inclusive dos casos específicos, em que a liderança pleiteia e advoga as exceções. Nesse mecanismo, inclui-se, ainda, a questão do acesso e distribuição das cestas básicas, das lonas e das referidas destinações.

Nesse sentido, tanto a constituição quanto a organização em "acampamento" institui-se como repertório fundamental, como ação político-coletiva dos movimentos e organizações sociais, na luta pela terra. Tornou-se, em regra, a lógica de que estar no acampamento torna-se a forma de legitimação da pretensão de ser assentado. Ressalta-se a ideia de parceria entre o movimento e a Superintendência, uma vez que caberia aos movimentos o papel de organização e controle dos acampamentos, configurando-se, assim, um canal em que o vínculo e o compromisso são definidos por essa troca mútua.

Em tal processo, a "forma acampamento" é definidora como repertório de ação para o acesso à política de reforma agrária e, ainda que alguns servidores critiquem ou discordem de tal prática, padroniza a forma como se concretiza a relação de parceria entre o Órgão público e os movimentos. Percebe-se que subjaz, nessa dinâmica de relação, o estabelecimento de atribuições recíprocas, a priorização de agendas políticas por parte do órgão e, em outra ponta, a indicação de terras a serem desapropriadas, retomadas

\footnotetext{
${ }^{5}$ A Ouvidoria Agrária Nacional (OAN) funcionou como um órgão ligado ao Ministério do Desenvolvimento Agrário (MDA), criado com o objetivo de prevenir e mediar conflitos na área rural. Foi o principal articulador da Comissão Nacional de Combate à Violência no Campo, criada em 2006 com o objetivo de "sugerir medidas para prevenir, combater e reduzir as diversas formas de violência praticadas contra trabalhadores rurais, proprietários rurais, remanescentes de quilombos, ribeirinhos e atingidos por barragens" (Portaria Interministerial 1.053, 2006). Tal comissão é composta por representantes dos Ministérios da Justiça (inclusive das Polícias Federal e Rodoviária Federal), do Desenvolvimento agrário, do Meio ambiente, da secretaria de Direitos humanos e do instituto de Colonização e Reforma agrária (Incra).
} 
ou destinadas, bem como a relação de beneficiários a serem contemplados. $\mathrm{Na}$ parte de consolidação do Projeto de Assentamento, é o movimento social que indica, negocia e pressiona por execução em relação às infraestruturas a serem implementadas, a assistência técnica etc.

É possível, pois, identificar a "forma acampamento" como uma pressuposição também assumida e administrada por parte dos servidores, talvez, inclusive, agindo ou estipulando uma condicionante, sob forma de coerção, a nortear o ingresso na política pública de reforma agrária (Sigaud; Ernandez; Rosa 2010).

Trata-se de uma prática transformada em categoria, por parte dos movimentos sociais, que acaba sendo legitimada pelo Estado, como forma de ação coletiva e política. A variável desse modelo constitui-se tanto pelo movimento quanto, em grande parte, pelo Estado, no reconhecimento da "forma ocupação" como fundamental repertório de luta. Pode-se dizer que, conjugadamente, essa forma acampamento-ocupação, como movimento contínuo, é um repertório em pleno funcionamento, legitimado seja na parte orgânica, admitida, seja na parte funcional da própria linguagem entre o Estado e os movimentos (Castro, 2013).

Constatou-se que o conceito de ocupação, como repertório, assumiu, além da "ocupação da terra”, a "ocupação do Incra”, como prédio, local, onde se encontram o superintendente e os servidores das pastas específicas. A “ocupação do Incra” torna-se, assim, a ocupação de um “território" importante na luta pelo acesso à terra e às políticas de reforma agrária. Trata-se de uma especificidade tornada praticamente uma rotina, de certa forma "institucionalizada", inclusive por parte dos funcionários e dos movimentos.

Como questão específica, diferencia-se, tanto pelo "espaço ocupado" quanto pelos "sujeitos ocupantes". Em outros termos, a "ocupação do Incra" pelos movimentos sociais torna-se algo diferente e "tolerado", ainda que formalmente seja uma atividade ilegal, diferente do que seria uma ocupação de outro órgão público, federal, estadual ou municipal, protagonizado por outro segmento social, urbano, por exemplo. Ao assumir a ocupação como um "repertório de pressão", por um lado, os integrantes e lideranças dos movimentos acreditam que se trata de um instrumental que acelera a 
efetivação das políticas e das demandas indicadas. Pelo lado dos servidores, é corrente a percepção de que as demandas são reconhecidas, no entanto, para alguns, a ocupação atrasa a resolução das emergências e do próprio funcionamento do órgão.

Em relação à ocupação da terra, notou-se a diferença que, por vezes, o próprio Incra faz, de outras formas de ocupação, como aquela realizada por posseiros, daquelas feitas por grupos espontâneos. Nessa perspectiva, o próprio órgão elabora e divulga sua estratégia de abordagem, filtrando sua interlocução nas variáveis dos modelos de ocupação. Assim, para o Incra, há os movimentos organizados (LCP e MST), há os grupos que estão sob a "tutela" do movimento sindical (Federação dos Trabalhadores na Agricultura de Rondônia - FETRAGRO) e há os grupos "espontâneos" ou "independentes", aqueles que se encontravam na terra, em regime de "posse antiga", ou se organizam, na forma de uma "associação", ou simplesmente formam o grupo para a atividade ocupacional, escolhendo lideranças e fazendo-se representar por elas.

Há abordagens e leituras analíticas (Wolford, 2010; Castro, 2013; Bruno, 2012) que interpretam a atuação dos movimentos sociais do campo, sob o ângulo desses processos participativos, como um "momento de democracia participativa" que ocorreria não tanto por um design participativo, muito mais por um déficit do órgão em executar políticas substanciais de reforma agrária, sobretudo por ela não ter sido uma prioridade no contexto nacional. Portanto, a participação dos movimentos sociais do campo (MST, LCP, FETAGRO), ao pontuar essa participação relacionada à implementação de políticas públicas pelo Incra, na verdade estão, os movimentos, "denunciando" a falta de prioridade política do Estado brasileiro com todas as suas condicionantes: orçamento precário, falta de funcionários, estruturas etc.

Isso remete, pois, a aspectos que, mesmo não inscritos na formalidade, efetivam-se na prática: participação dos movimentos no processo de seleção, indicação de propriedades a serem vistoriadas e desapropriadas, pauta de prioridades, entre outras. A respeito disso, é preciso anotar que, mesmo discordando em aspectos circunstanciais, boa parte dos agentes públicos 
considera que, "se não houvesse os movimentos sociais, não se efetivaria nada a respeito de política de reforma agrária".

A lógica da "parceria" desenvolvendo nessa relação entre Estado e movimentos sociais do campo. E tal relação foi se consumando e constituindo na forma de distintas sub-relações. Muitas regras, tácitas ou implícitas, foram assimiladas, estabelecendo-se vínculos que vão da familiaridade a dinâmicas de cooperação, entre servidores e lideranças dos movimentos sociais do campo.

Essa tal "parceria" operacionaliza-se por meio de distintos repertórios, indicando distintos significados, muitos inclusive naturalizados no cotidiano do funcionamento do órgão estatal. Por essa conexão de parceria, a dinâmica do político e da política perpassa e incide desde forma constitutiva da luta pelo acesso à terra, passando pelas interações e influências político-partidárias, até a implementação ou efetivação das políticas consumativas, fomento, custeio, estruturas, na fase de consolidação do assentamento.

Uma dimensão a ser posta é que, a depender do formato institucional dos órgãos, as ações dos movimentos sociais podem influenciar inclusive os procedimentos e normas internas que orientam as políticas públicas destinadas. No caso pesquisado, foi possível constatar que, levando em conta as agendas dos movimentos sociais que pautavam tanto ações diretas de reforma agrária (Incra), quanto ações de regularização fundiária (Programa Terra Legal), uma série de instruções, memorandos internos, grupos de trabalho e outros procedimentos passaram a ser analisados e implementados pela própria Superintendência.

\footnotetext{
${ }^{6}$ Por "lógica de parceria" ou "relação de parceria", entende-se os distintos procedimentos que balizam as relações entre os agentes públicos da Autarquia e os movimentos do campo, por meio das lideranças e coordenações. Trata-se de uma visão (compreensão e sentido do papel e função do movimento por parte dos servidores), na reivindicação da política pública (pressão), mas também das dinâmicas de cooperação. Assim, na implementação das políticas agrárias e de seus processos burocráticos, aproveita-se do conhecimento, da organicidade e atuação desses movimentos junto às suas bases. Tal "relação de parceria" se processa não por planejamento prévio, nem previsão, mas de forma espontânea e dinamicamente recriada. Pode-se dizer, também, que tal forma de interação ocorre em função do descaso programático, por parte do Estado, quanto à política agrária, materializado na redução orçamentária, problemas de gestão e secundarização da questão agrária, como política de Estado e de governos.
} 
De igual maneira, a "relação de parceria", na forma concreta de efetivação de determinadas políticas, sobretudo quanto à aplicação de recursos, fez sentir, conforme observação, a influência dos movimentos. Isso ocorreu seja por pressão por retomadas de terras públicas, negociação, atuação jurídica da Procuradoria especializada, seja nas escolhas ou priorização de áreas a serem atendidas, quanto à infraestrutura dos Projetos de Assentamento.

Por isso, que não é incomum o direcionamento de algumas críticas, por parte dos servidores, em relação ao modelo de atuação do Incra, conforme alguns, agindo "a reboque" dos movimentos sociais. Nessa percepção, mesmo reconhecendo a importância da pressão desses movimentos, isso tem feito com que o órgão de terras se perca em seus objetivos, abandonando o papel e o controle do processo de efetivação da política de reforma agrária.

Constata-se, assim, que transcende a relação automática Estado-Sociedade Civil, ou Estado-movimentos sociais. Em perspectiva analítica, é fundamental filtrar também o papel desenvolvido pelos atores em relação. O Incra, enquanto Estado presente nessa interlocução, transforma-se não somente em um campo de disputa, onde as controvérsias são assimiladas e sistematizadas na forma de política pública definida. É um território onde também os sujeitos se constituem, se representam e definem ou redefinem suas atitudes e papel em consonância com essa perspectiva. De perto, é um espaço onde as "trocas-recíprocas", na forma de consenso, dissenso, enfrentamento ou conciliação, influenciam e impactam.

Não se trata isoladamente de entender esses processos interativos e participativos, somente à luz de enfrentamento, mas de considerar limites e possibilidades de mutações estratégicas e objetivas em relação ao fim prescrito e alcançado. Em perspectiva de atuação política direta, coexistem burocratas, militantes dos movimentos sociais, lobbies patronais, ativistas político-partidários. A fronteira de atuação de um ou de outro nem sempre é perceptível (Castro, 2013).

A ideia central de Wolford (2010) é que esse modelo de "democracia participativa" acontece por acaso e não por proposta. Ou seja, mediante a falta de recursos do Incra e da retirada da reforma agrária como agenda política, os servidores do órgão, em regra, ajustam sua atividade às 
demandas dos movimentos sociais do campo. De certa forma, no cotidiano das suas atividades, chegam a transgredir as margens de um comportamento aceitável e legal. Assim, a questão agrária no Brasil passou a ser participativa, não por intenção, mas por necessidade. Assim ocorre, sobretudo, pelos mecanismos de pressão exercidos pelos movimentos sociais sobre o órgão responsável. O fenômeno da participação, no entanto, deixa de ser uma atividade, transformando-se mais em uma relação. Ressalve-se, pois, que, para os indivíduos não representados pelos movimentos, o sistema político, em regra, mantém-se na linear e histórica lógica de privilégio dos grandes proprietários, ou seja, a marginalização.

Na conclusão da pesquisa de Wendy Wolford (2010), um dos argumentos analíticos, proposto com base na observação, é esclarecedor:

Defendo que a reforma agrária no Brasil rural - tanto como uma questão política como uma prática territorial que resulta na distribuição de terras aos beneficiários anteriormente sem-terra - pode ser entendida, de forma produtiva, como um site da democracia participativa. Neste sentido, o termo site implica uma área física, um momento temporal (uma instância), um domínio cultural, e um espaço institucional de "encontro", onde as linhas dentre o Estado e a sociedade civil estão menos distintas (Wolford, 2010, p.94) ${ }^{7}$

Sempre há o risco de limitar a análise pelo clivo da distinção entre Estado e sociedade civil, como se fossem categorias distintas. Por isso, há que se considerar que, nesse campo de atuação, há variáveis que não se encaixam nessa dicotomia. O que, em primeiro plano, não descarta a percepção de que é nessa relação entre movimentos sociais e Estado/Incra, que se substantiva esse espaço e processo de participação e democracia. Não é, no entanto, um espaço planejado, mas essencialmente pragmático,

\footnotetext{
${ }^{7} \mathrm{I}$ argue that land reform in rural Brazil - both as a political issue and as a territorial practice that results in the distribution of land to formerly landless beneficiaries - can be productively understood as a site of participatory democracy. In this sense, the term 'site' implies a physical area, a temporal moment (an instance), a cultural field, and an institutional space of 'encounter' (Dagnino 2002), where the lines between state and civil society are blurred (Wolford, 2010, p. 94, tradução livre).
} 
sobretudo ante o descaso e vontade política em dar à autarquia um status de programa político.

Fala-se, portanto, do desenvolvimento de uma determinada competência instituída e instituinte, que reconhece, na ação coletiva dos movimentos sociais do campo, um papel preponderante de influência nas políticas de reforma agrária. Essa competência, entretanto, se preestabelece nessa relação a partir do reconhecimento e legitimação pelo Estado dessa "forma-movimento" (Rosa, 2011), e se dimensiona como "relação de parceria”. Dessa forma, categorias são construídas pelo movimento e assimiladas pelo Estado, são internalizadas e constantemente atualizadas nas práticas interacionais entre lideranças dos movimentos sociais e funcionários da autarquia (Rosa, 2011; Penna e Rosa, 2015). Constata-se, assim, que uma compreensão mais apropriada acerca da influência dos movimentos sobre as políticas exige tomar em consideração o papel da burocracia e da forma como a mesma se efetiva.

No plano, onde se dinamiza a correlação de interesses do Estado, pela sua via autárquica e burocrática ante a perspectiva do patronato rural, há evidências marcantes. Invariavelmente, os cargos de gestão/chefia da Superintendência do Órgão têm sido e vêm sendo ocupados por pessoas que já tiveram algum cargo do Executivo ou Legislativo, ou então que intencionam voltar a tais cargos.

Nesse compasso é que se compreende a atuação do lobby patronal, como ator estratégico em termos de viabilizar os interesses da classe junto à autarquia agrária. Essa atuação corporativista encontrou, no órgão fundiário, um campo propício de operacionalização. Uma vez que tocava ao Incra a tarefa de dirigir, implementar e ordenar a ocupação territorial (direta ou indiretamente), a estratégia adotada para as "apropriações territoriais" inevitavelmente contou com os procedimentos e burocracia do aparelho estatal.

Nesse sentido, a atuação patronal encontrou, no órgão, um campo de ação e cooperação estruturante. Moacir Palmeira, nesse sentido, analisa os mecanismos de funcionamento da máquina estatal na forma como operam e cooperam. Percebe-se que é nessa relação que se fortalecem os esquemas de "troca de favores", "apadrinhamento de funcionários por políticos", laços indicativos e típicos do "estado cartorial", característico da dinâmica 
do "lobby patronal" (Palmeira, 1994). O vértice ou o ponto de intersecção - entre essa prática consubstanciada que une a estrutura burocrática do Incra com o conglomerado de pretensões da oligarquia rural no Estado pode ser percebida também sob outra matiz. Foi possível constatar que um número considerável de ex-gestores, ex-superintendentes, ex-procuradores, que serviram ao Incra em Rondônia, prestam serviços técnico-jurídicos, sobretudo, a grandes interesses ou pretensões privadas, que têm como objeto a regularização de grandes propriedades em Rondônia. ${ }^{8}$

Fundamental, nesse sentido, perceber que os blocos vinculados a interesses patronais, junto ao Incra, não só agem na defesa das próprias pretensões fundiárias, como intervêm na elaboração legislativa de proteção dos próprios interesses ou de minar as pretensões de interesses ligados aos grupos e movimentos sociais. Assim o foi, em relação ao grupo político de composição do governo Sarney, a fim de impedir a implementação do I PNRA (Silva, 1987), e assim está sendo na alteração da Lei Agrária (marco legal), com atuação protagônica da Bancada ruralista de Rondônia ${ }^{9}$.

Ao transitar da regência militar para a experiência de redemocratização, o órgão público de terras e reforma agrária via-se, portanto, "apropriado”, em grande parte por uma convergência de interesses. É possível, no entanto, detectar que, no contexto da redemocratização, no deslocamento de uma política de colonização para uma política de reforma agrária,

\footnotetext{
${ }^{8} \mathrm{~A}$ título de exemplo, pode-se constatar, em rápida pesquisa, o grau de intervenção técnica e de influência política de ex-superintendentes do órgão, ex-procuradores que atuam, sozinhos ou em sociedade, com claros e públicos interesses privados, sobretudo na demanda por defesa e regularização de grandes latifúndios: Luiz Duarte Freitas e Sebastião Martins dos Santos (procuradores e ex-Superintendente adjunto), Petrus Emile Abi-Abib (ExSuperintendente e procurador), Amir Lando (meio político e grande proprietário e exprocurador do Incra), Orestes Muniz e Odair Martini ( ex-superintendente do Incra); Amadeu Machado (Ex-procurador).

${ }^{9}$ A influência de 3 Congressistas (Lúcio Mosquini, PMDB, Valdir Raupp, PMDB, e Acir Gurgacz, PDT), alinhados ao governador do Estado, Confúcio Moura, PMDB, foram de fundamental importância no sentido de intervirem junto ao Relator do Projeto que viria a se tornar a Lei no 13.465/2017, em consonância, não só com os interesses da grande grilagem de terras no Estado, como também no sentido de transferência da União para o Estado da incumbência da efetivação da regularização fundiária. Entre as principais alterações dispostas na Lei aprovada, consta a possibilidade de regularização de grandes áreas em até 2.500 hectares, a regularização de ocupações irregulares em Assentamento de Reforma Agrária e a redução em até $90 \%$ do valor a ser pago pelos pretensos proprietários de áreas acima de 240 hectares de terras.
} 
fomentou o acesso dos trabalhadores ao órgão. Nesse contexto, conjuntamente com os ares de renovação, inclusive técnico-burocrática, tornou-se possível, em muito, a mitigação e, em alguns casos, a anulação do forte lobby proprietário (Palmeira, 1994).

Não deixa de ser um movimento dialético essa "convivência" em um mesmo espaço, sinalizando uma presença "proprietário-patronal” e a presença dos movimentos sociais, na forma de "ocupação do prédio". E, por certo, essa nova configuração assustou ou contou com resistências dos funcionários do Incra. No entanto, essa dinâmica foi ganhando cada vez mais "corpo e força”. Por mais que haja, em certos meios, um saudosismo como forma de resistência expressa, predomina a compreensão de que os movimentos sociais constituíram e fortaleceram um importante espaço de interação político-administrativa. Reconhece-se, salvo exceções, que essa intermediação potencializa e dinamiza, com "o interlocutor privilegiado", o debate em torno da questão agrária no Estado de Rondônia.

Como se apreende, múltiplas são as formas que conectam a dinâmica dos movimentos sociais do campo nesta inter-relação com o Estado. Essa diversidade não só marca a dinâmica dos processos participativos, como também vai definindo (constituindo) os diversos atores. A percepção desse fenômeno, tanto na forma quanto nos efeitos, leva a perceber os limites em uniformizar a interpretação de tal realidade como se fosse apenas uma relação entre Estado-sociedade civil. Embora herdeiros desse legado culturalmente estabelecido, é fundamental perceber que, no plano das interações entre Estado-movimentos sociais do campo, a heterogeneidade que marca essas relações faz levantar uma série de suspeitas sobre as categorias padronizadas de análise.

Nesse sentido, converge uma série de abordagens (Wolford, 2010; Avritzer, 2016), pontuando sempre para os limites de uma análise reducionista da relação Estado-movimentos sociais, bem como da sua atual e desafiadora complexidade. Um dos mais circunstanciais reducionismos é interpretar essa relação sob a categoria do "clientelismo", o que não contém todo o sentido interacional. Em regra, não se trata de padronizar tal compreensão em categorias, como se a dinâmica relacional pudesse ser comportada em noções específicas combinadas (Gupta, 2006). 


\subsection{MOVIMENTOS SOCIAIS DO CAMPO E A INSERÇÃO ESTATAL: ENTRE APORIAS E PERSPECTIVAS}

Uma questão recorrente que pauta a análise da relação entre Estado e movimentos sociais do campo diz respeito à perspectiva da representação política e seu papel referente aos objetivos imediatos ou a médio e longo prazo. Em certo grau, a ideia de "ter um representante" é muitas vezes alimentada, no seio dos segmentos sociais, deixando transparecer que a mediação política, por essa via, é sinônimo de força e que, ao fim, a intervenção poderia objetivar a realização de "favores e obras", em prol do público da reforma agrária, através da instituição responsável por tal função (CASTRO, 2013).

Como se constata, a opção pela resposta política institucional, em todos os níveis de governo, tem sido uma variável constante, debate esse articulado pelos movimentos sociais do campo. O fato de ingressar no mundo e na lógica do Estado talvez ressoe como possibilidade de fomentar uma nova institucionalidade pública. No entanto, em grande parte, pode ser constatado que a própria existência, a constituição dos movimentos sociais, acabou por ser absorvida pela agenda do Estado, bem como por sua burocracia.

Nesse contexto, a dimensão participativa dos movimentos sociais do campo, no contexto sociopolítico e econômico, vislumbrava três atitudes primordiais, que em muito convergem: 1) a participação como forma de acesso à competência efetiva, objetivada pela "lógica de resultados", ou seja, para acessar a política pública, obtendo o seu resultado final, na forma de "favores, estruturas, fomento etc". Nessa perspectiva, a lógica de favorecimento e favorecidos incorpora-se na percepção bilateral dessa dinâmica (absorção clientelista); 2) a participação na dinâmica estatal, buscando acessar as políticas previstas pela inserção do movimento na "arena estatal", como locus provedor possível. Dilui-se a ideia de resistência ou enfrentamento político, filtrada pela demarcação de um novo sujeito interlocutor, contudo, pontual ou circunstancial (absorção instrumental e incorporada); 3) constituição de um institucionalismo compartilhado, ou 
seja, ao trilhar pelo caminho da participação, propõe-se o fortalecimento da instituição corporativa (sindical), como meio de acessar resultados, firmado no reconhecimento. Quando não se pode com o Estado, "associa-se" estrategicamente a ele, buscando tornar possível o reconhecimento (absorção instrumental).

Muitas são as variáveis ou instrumentais dessa forma de participação. Como já foi dito, a depender da conjuntura política nacional e grupos que compõem a base de sustentação, a dimensão participativa é mediada pelo Partido Político, para cargos de gestão e de chefia, podendo inclusive contar com a indicação e participação dos movimentos sociais. ${ }^{10}$

Em outra dimensão, sobretudo percebida em períodos eleitorais, tem sido comum o vínculo pontual que se expressa no apoio a nomes ligados ou vinculados às "causas sociais do campo", como campo de atuação, considerado importante para tais movimentos ("ter alguém lá"). Nesse sentido também, sempre que necessário, na atuação em plano estadual ou federal, constatou-se a estratégia de firmar determinadas "alianças" (muitas vezes independente do Partido), que potencializassem ou intermediassem as articulações, burocráticas ou governamentais, em torno da causa agrária.

Percebe-se aqui que, em regra, para boa parte dos movimentos sociais do campo, a lógica é, em virtude da atuação pontual, de determinado nome eleito, estabelecer ou demarcar, por dentro do Estado/Instituição, um campo de debate, em que as "pautas de demandas" do movimento sejam apresentadas e discutidas. Assim, "ter alguém lá" significa igualmente uma ponte de acesso à participação, discussão e encaminhamento das demandas, conforme boa parte do senso comum de membros dos movimentos.

Boa parte das análises foca no impacto negativo que incidiu sobre os movimentos sociais do campo, desde o ingresso de partidos de esquerda nos governos (Martins, 2016, Ricci, 2013). Entendem que, em regra, são

\footnotetext{
${ }^{10}$ Nas duas últimas décadas, aliás, essa prática tem sido habitual. A indicação é feita, em regra, pelo Partido político de plantão, indicando nomes do próprio partido ou de sua base aliada. Entre 2003 a 2015, para o cargo de superintendente na SR/17 (Rondônia), foram indicados dois nomes ligados ao Partido dos Trabalhadores (legitimados pelos movimentos sociais do campo), e atualmente ocupa o cargo indicado da base de sustentação (PSDC) um ex-Deputado estatual que concorreu às eleições inclusive vinculando, ao seu nome, seu exercício profissional (Brito do Incra).
} 
instaurados vários mecanismos de cooptação e subalternização das mobilizações sociais no campo e que isso teria, de forma extraordinária, acontecido com a emergência do governo Lula, em 2003.

Outras análises acenam para um componente mais estrutural, no sentido de que as formas de participação precisam ser relidas no contexto das alianças políticas e econômicas no Brasil, na expressão mais elaborada do "capitalismo de laços" e "presidencialismo de coalisão" (Limongi; Figueiredo, 1998; Lazzarini, 2011), entre outros. Nesse campo, percebese, com maior clareza, o impacto sentido pelos movimentos sociais quando de uma maior centralidade do mercado no direcionamento das políticas públicas.

Nesse sentido, uma sucessão de pautas conservadoras vai tomando e ganhando espaço no contexto recente, configurado por um esvaziamento político dos direitos sociais (inclusive revogados em grande parte), indicando com clareza uma guinada cada vez mais neoliberal e ao mesmo tempo conservadora, como programa de governo (AVRITZER, 2016).

O desenho conjuntural mapeava, assim, um fenômeno que significou, em muito, uma desagregação, uma ruptura entre o campo político e a participação social. Setores significativos dos movimentos sociais se viram envoltos em um verdadeiro cenário de conflitos e enfrentamentos, e isso, especialmente, em relação ao próprio "governo de esquerda".

Como consequência direta, impõe-se um descaso com a questão agrária, assim como com a agenda ambientalista. Isso se complementa, na forma de descompromisso, por uma "ausência de agenda", quando se trata de pautas voltadas aos povos e comunidades tradicionais (indígenas, quilombolas, ribeirinhos, extrativistas, entre outros). A confluência desses elementos demarca, com esse impasse, a expectativa da possibilidade de uma relação programática de políticas públicas entre os movimentos sociais e o Estado.

Assim, é possível constatar que grande parte da causa do distanciamento do Partido dos Trabalhadores com sua base, sobretudo dos movimentos sociais do campo, deu-se no campo do "presidencialismo de coalisão", incidindo de certa forma na despolitização de toda uma agenda progressista, sistematizada teórica e pragmaticamente nas lutas dos movimentos sociais. 
E, enfim, ao pautar a ação política pela "lógica da governabilidade", os governos do Partido dos Trabalhadores indicavam de forma clara, por seu lado, a razão do impasse de uma agenda de compromissos.

Ilustra esse cenário a pesquisa e estudo, sob a coordenação de Maria Celina D’Araújo (2009), ao examinar o perfil social e político dos cargos de alto escalão, em relação às lideranças sindicais com vínculos com os movimentos sociais.

Tabela 8 - Participação de Sindicalistas e Entidade Patronal por Governo em relação a Ministérios e Ministros (1985-2008)

\begin{tabular}{|l|c|c|c|c|}
\hline \hline & $\begin{array}{c}\text { No de } \\
\text { sindicalistas no } \\
\text { Ministério }\end{array}$ & $\begin{array}{c}\text { \% em relação } \\
\text { ao total de } \\
\text { Ministros }\end{array}$ & $\begin{array}{c}\text { Participação } \\
\text { de entidade } \\
\text { patronal }\end{array}$ & $\begin{array}{c}\text { \% em relação } \\
\text { ao total de } \\
\text { Ministros }\end{array}$ \\
\hline Sarney & 4 & 8,0 & 10 & 18,9 \\
\hline Collor & 3 & 8,6 & 9 & 25,7 \\
\hline Itamar & 4 & 9,3 & 4 & 9,1 \\
\hline FHC1 & 2 & 5,0 & 8 & 20,5 \\
\hline FHC2 & 2 & 3,6 & 15 & 26,8 \\
\hline Lula 1 & 16 & 26,2 & 6 & 9,4 \\
\hline Lula 2 & 6 & 15,8 & 5 & 13,2 \\
\hline Total & 37 & 11,5 & 57 & 17,6 \\
\hline \hline
\end{tabular}

Fonte: Própria Autoria com base em: D’Araújo, 2009

Nesse sentido, manifesta-se importante e de efeitos práticos o caráter dessa relação direta/indireta entre as lideranças dos movimentos sociais e sindicais, quando participantes de cargos no governo. Conforme D'Araújo (2009), não se pode entender esses indicativos à luz da dicotomia técnico-burocrática de um lado e políticos de outro, uma vez que se torna plenamente possível adaptar o aparelho do Estado aos interesses do partido.

Isso acaba ocorrendo devido ao fato de os resultados da pesquisa confirmarem que, no caso dos dirigentes vindos do setor público (carreiras públicas), havia, por parte deles, fortes vínculos com os movimentos sociais, terceiro setor e, em especial, com os sindicatos. Isso denota um nível de 
participação e inserção diferenciada, demonstrando uma inédita confluência tanto ideológica quanto corporativa entre governo, movimentos sociais e funcionalismo público.

Outro elemento que coincide no levantamento feito diz respeito, de forma inédita, aos ministros com algum tipo de envolvimento com os movimentos sociais. Nessa perspectiva, é possível destacar, conforme Tabela 9, o percentual de participação em movimentos sociais relacionados aos ministros nomeados, nos governos do período de redemocratização.

Tabela 9 - Ministros e participação em movimento social por governo (alguma participação)

\begin{tabular}{|c|c|c|}
\hline Governos & Frequência & $\begin{array}{c}\text { \% em relação ao total de } \\
\text { ministros }\end{array}$ \\
\hline Sarney & 19 & 35,9 \\
\hline Collor & 8 & 22,9 \\
\hline Itamar & 15 & 31,8 \\
\hline FHC1 & 11 & 28,2 \\
\hline FHC2 & 14 & 25,0 \\
\hline Lula 1 & 28 & 43,8 \\
\hline Lula 2 & 17 & 45,9 \\
\hline Total & 112 & 34,4 \\
\hline
\end{tabular}

Fonte: D’Araújo, 2009

Na perspectiva do estudo feito (D’Araújo, 2009), são retratados ainda alguns elementos importantes, no campo da ocupação dos espaços dos ministérios. Em primeiro lugar, a constatação de que há setores ministeriais blindados, como áreas preservadas para setores economicamente alinhados, sobretudo pelos aspectos "técnicos" do mercado (atividades monetárias, fiscais e arrecadação de recursos).

Em segundo lugar, como historicamente as indicações aos ministérios refletem os alinhamentos políticos, essa lógica não foi rigorosamente pautada nos governos Lula, dado inclusive à forte presença sindical, indicando, assim, um espaço de maior receptividade da diversidade que os caracteriza. Por certo, tais alterações no cenário indicam avanços formais 
na participação democrática, mas, em tese, isso não sinaliza para avanços concretos e efetivos. Muito menos, não implica uma ruptura com a clássica lógica do clientelismo e com as práticas corporativas.

Em relação a esse debate, havia uma expectativa de que haveria uma dinamização da política agrária no governo Lula. Havia, igualmente, uma "identificação" dos movimentos sociais do campo com o presidente, seja pelo itinerário histórico seja em sede de promessas verbalizadas, publicamente, na convivência da figura política de Lula com as lutas sociais do campo. Fato é que as mobilizações chegaram a diminuir, na expectativa de que as respostas governamentais atendessem a tais demandas. Atribui-se ao perfil sindicalista de negociador do presidente o estabelecimento de um diálogo com os movimentos e um arrefecimento na adoção de políticas de repressão e criminalização, por parte do Estado (Engelmann, Gil, 2012). No entanto, constatou-se que o governo Lula acabou não cumprindo as metas do PNRA e sequer executando uma política de Reforma agrária, descumprindo também as promessas feitas.

O que se viu, portanto, foi a efetivação de reestruturação dos assentamentos antigos, convergindo, pois, mais para atender o fornecimento de força de trabalho às indústrias vinculadas ao agronegócio, que para executar um programa de democratização do acesso à terra. De tal forma, a tolerância sentida, por parte dos movimentos sociais do campo, no primeiro mandato, transformou-se em atividades de protestos e ocupações, em um segundo. Registre-se, contanto, que essa dinâmica não foi estabelecida com a mesma intensidade que em governos anteriores, e não mais com a mesma base social (Engelmann; Gil, 2012, p. 7-8).

Em abordagem mais aproximada, constatou-se que houve, por parte do governo, na verdade, uma tentativa de conciliação entre os dois modelos agrícolas. De um lado, o fortalecimento dos assentamentos na direção da agricultura familiar (produção de alimentos para programas de alimentação e combate à fome e à pobreza) e, de outro, a injeção de incentivos ao agronegócio, sobretudo o setor voltado para a produção em grande escala e 
exportação ${ }^{11}$. Os dois comportamentos políticos, expressados objetivamente nos programas de governo, acaba por reforçar a hegemonia econômica do latifúndio, protagonizado pelo agronegócio, com fortes vínculos que uniam não só a elite agrária nacional quanto também a internacional.

Nesse contexto, é consenso falar em "desmobilização" dos movimentos sociais do campo, como resultado desta política estatal voltada para a questão agrária e agrícola no período (Engelmann; Gil, 2012, p. 8). Por outro lado, constatou-se que tal fato também se operou como resultado estatal em "integrar" os sindicatos e movimentos sociais, demonstrando, senão direta, indiretamente, a perspectiva de "esvaziá-los" politicamente, reorganizando-os para um melhor controle político (Martins, 2016; Ricci, 2013). Esse impacto fez-se sentir nos processos de organicidade e atuação pública dos movimentos sociais do campo, por todo o Brasil.

\subsection{DINÂMICAS PARTICIPATIVAS E OPORTUNIDADES POLÍTICAS: "DA AÇÃO AO MOVIMENTO"}

Não se pretende aqui entrar no debate acerca do que é ou do que deixa de ser uma ação coletiva ou movimento social. Pelo óbvio, parte-se da ideia de que ação não é movimento, o qual, em tese, está mais relacionado a uma reação ordenada e direcionada a um objetivo específico. Em regra, e isso se aplica aos movimentos sociais do campo, o movimento social, como reação organizada, caracteriza-se por uma defesa ante uma situação de risco, ante uma adversidade, ante determinado interesse, fortalecido pela confluência, gerando graus diferentes de sociabilidade capaz de ativar uma rotina de atuações coletivas, sob os mais distintos repertórios.

Entende-se, apenas para ampliar o campo de análise, que a ação coletiva nem sempre é necessariamente organizada, muito embora ative e

\footnotetext{
${ }^{11}$ Neste sentido, arautos do agrobusiness vieram a público para externar apoio e constatar que ele (governo Lula), "foi ótimo para o setor", cf.

http://revistaepoca.globo.com/Revista/Epoca/0,, EMI138951-15223,00O+AGROPETISMO.html; Da mesma forma, atestavam que "nenhum outro partido político fez mais pelo agronegócio em Mato Grosso do que o PT". Cf: www.reportermt. com.br/politica/erai-afirma-que-pt-foi-o....agronegocio.../39516; Assim, o setor, em 2014, sentia-se muito à vontade para convocar o "volta Lula”, cf: https://oglobo.globo.com/brasil/ volta-lula-entoado-por-empresarios-do-agronegocio-12376141.
} 
mobilize o interesse de grande número de pessoas. Assim, os próprios repertórios utilizados podem significar comportamentos não estruturados, na forma de reação a determinado fato ou situação. Necessitaria, portanto, que a ação coletiva incorporasse alguns elementos, para que viesse a se tornar uma ação coletiva organizada ou um movimento social.

Há um consenso, em grande parte dos autores referenciados neste estudo, que os movimentos sociais, em regra, têm uma identidade, um ou mais opositores, projeto de vida e de sociedade, possuem uma certa continuidade, determinadas práticas de pressão (repertórios) e podem surgir não apenas como uma reação, logrando objetivos mais amplos e conscientemente buscados. Concorda-se, ainda, que a própria ação coletiva pode se contextualizar em um campo de ambivalências e ambiguidades ${ }^{12}$ que, em muitos casos, instrumentalizada, reproduz ou reconstitui o esquema de dominação e domesticação dos atores sociais e de suas demandas.

$\mathrm{Na}$ análise de todo o processo de colonização, constata-se, sem muito esforço, que a insistência de um passado presente, na forma de desigualdades e violências extremas, se sobrepõe. A face mais cruel dessa moeda retrata-se na concentração da terra e nos processos consequentes de espoliação, desrespeito, expropriação. Não sem lutas, resistências e mobilização, os camponeses, os povos tradicionais, os povos da floresta têm buscado saídas, forjado conquistas que miram tanto no reconhecimento e efetivação de direitos coletivos, quanto também na luta por acesso à terra e democratização fundiária. A partir da década de 1980, esses povos formaram movimentos na luta pela terra, organizaram-se instrumentalmente no reconhecimento de outras formas de estrutura fundiária, mobilizaram pautas territoriais, até então invisibilizadas, e demarcaram, ante a sociedade e perante o Estado, a posição política de diversas e distintas demandas. Novos repertórios

\footnotetext{
${ }^{12}$ Por ambivalência do fenômeno, compreende-se aqui a possibilidade de equívocos por parte da própria ação coletiva, quando, muitas vezes, "permite-se" capturar por respostas instantâneas ou pontuais às suas demandas, agindo de forma instrumental sob a diretiva de uma lógica de resultados, tão somente obscurecendo aspectos políticos e adversários políticos maiores. Já a ambiguidade diz respeito à incorporação de diretrizes de ações facilmente tangidas por interesses corporativos, no entanto, sob uma retórica de protesto ou de reivindicação política. Instrumentalizada a ação política, ela se torna facilmente refém de interesses estatais ou institucionais "bem localizados", enfim.
} 
oxigenaram a ação coletiva dos movimentos sociais do campo e passaram inclusive a ocupar outros espaços de debate, recriando e mesmo ressignificando novas fronteiras de disputa (novos espaços públicos).

No contexto da elaboração da Constituinte - segunda metade da década de 1980 - esses processos de mobilização e participação ganharam uma espetacular projeção. As oportunidades políticas, no contexto da reforma da Constituição, despertaram, por dentro da sociedade, o anseio de luta por acesso a direitos e reconhecimento. Ainda no cenário nacional, é possível constatar um processo de acúmulo e verticalização das lutas organizadas do campo, na década de 1990.

O contexto, imediatamente após a elaboração e promulgação da Constituição, projetou as lutas pela terra. $\mathrm{Na}$ Amazônia, dois importantes e trágicos acontecimentos, de um extremo a outro, alavancaram a questão agrária no campo nacional e internacional: o massacre de Corumbiara (RO), em 1995, e o massacre de Eldorado dos Carajás (PA), em 1996.

O Movimento dos Trabalhadores Rurais Sem Terra (MST), por seu turno, experimenta um processo de crise no início dos anos 2000. No entanto, ressurge como fator de influência, durante o primeiro mandato de Lula (Ondetti, 2006). Na verdade, para o autor, essa correlação histórica reforça a ideia de amparar a análise dos movimentos sociais do campo, na América Latina, sob o crivo da Teoria das Oportunidades Políticas.

Nesse sentido, afasta-se, em tese, da Teoria econômica clássica da ação coletiva, de Mancur Olson ${ }^{13}$, visto que, mais que a perspectiva dê resposta ou satisfação de interesses econômicos, individuais ou coletivos, é insuficiente para explicar a restauração dos movimentos sociais do campo, no

\footnotetext{
${ }^{13}$ Mancur Olson (1999), em sua "Lógica da ação coletiva", vai desenvolver a teoria da mobilização de recursos, cujo foco principal é pensar que não há uma identidade coletiva irracional nas ações coletivas, ou seja, os movimentos sociais se mobilizam e constroem sua racionalidade mobilizadora em torno dos grupos de interesses. Esse sentimento ou racionalidade seria a mola propulsora da organização, dinamicidade e estruturação dos movimentos sociais, constituindo-se, assim, no principal motivo para as mobilizações. A lógica organizacional pautar-se-ia pela utilidade (escolha racional), que conta com os estímulos como resposta (vantagens/desvantagens), determinando possíveis ganhos, como resultado da ação cooperativa.
} 
período. Também nesse aspecto, é essencial compreender os aparatos de ação, ou o repertório das ações coletivas, manejados pelos movimentos ${ }^{14}$.

Quanto aos repertórios utilizados pelos movimentos sociais organizados, em geral, objetivam "atrair" a atenção da opinião pública e dos meios de comunicação, bem como estabelecer um sistema de pressão sobre o Estado, por meio dos seus órgãos. Assim, ao adotar estratégias de confronto com as estruturas de poder local, acionam mecanismos e instrumentos burocráticos e políticos do poder central. Essa forma de atuação foi muito significante para a ação do MST na região amazônica.

As estratégias de protesto levam, inevitavelmente, a ação para o campo público e, assim, procedem-se as diversas formas de "aliança e simpatia", e conecta-se também a opinião pública. Nesse nível, os repertórios são os mais variados e circunstanciais possível: marchas de protesto, demonstrações, ocupações, bloqueios de estrada etc. (Ondetti; Wambergue; Afonso, 2010).

No plano da ação coletiva local, revela-se, como repertório fundamental, dispor de mecanismos que possam forçar um confronto com a elite fundiária regional, e com os seus defensores, nas estruturas de governo. Isso tem demonstrado não só a projeção do debate para uma esfera pública de atuação, como também tem, em grande parte, acelerado o ritmo de implementação de políticas públicas agrárias. Ainda que não apresente a solução da questão, faz pelo menos avançar o debate e a própria questão, no plano governamental.

Em Rondônia, a percepção da força dessa estratégia suscita, no plano dos repertórios, uma demarcação territorial dos movimentos junto aos próprios órgãos agrários e seus servidores, repropondo um nível variável e diversificado de formas de ação, conexões e inter-relações. Recria, igualmente, em variadas dimensões, a própria organicidade e papel do Estado,

\footnotetext{
${ }^{14}$ Entende-se, aqui, por "repertório" todo um conjunto de formas de organização, de táticas, de protesto e de resistência que, culturalmente, por serem compartilhadas, estão disponíveis aos agentes e militantes dos movimentos sociais do campo, em determinado espaço/ território, e em determinado momento histórico. Enquanto conhecimento compartilhado, o repertório revela tanto o "modus operandi", através dos quais as exigências são processadas, como também as questões estruturais subjacentes. Nesse sentido, as condições de trabalho, fatores demográficos, tecnologias, papel do Estado, retratam e determinam a diversidade nas ações coletivas, que podem ser utilizadas.
} 
no órgão ali representado. $\mathrm{Na}$ última década, isso tem se verificado cotidianamente num verdadeiro processo de "ocupação" da Superintendência e Unidades Avançadas, por parte das lideranças, por meio de reuniões espontâneas ou pré-agendadas, audiências sobre questões pontuais ou coletivas, em diferentes setores dos órgãos agrários.

Constitui-se, assim, um repertório diferenciado em relação à forma antes existente (sobretudo década de 1980), quando o órgão de Estado era um dispensador ou provedor na estratégia dos programas de colonização. Esvaziava-se, nesse repertório tradicional, a percepção política do coletivo que demandava. Agora, em muito, a questão agrária, viabilizada pelo sujeito coletivo que a reivindica, ganha maior conteúdo político e mobilizador.

Sob o enfoque das "oportunidades políticas", merece destaque considerar como os movimentos sociais, em seus processos de mobilização e confronto, reinterpretam a própria realidade agrária, imperativo das condições e circunstâncias em que vivem seus agentes. Assim, percebem a dimensão sistêmica produzida e reproduzida, instrumentalizando essa compreensão como fator de mobilização.

No início dos processos de colonização, a contribuição desse instrumental foi intensamente alimentada pela perspectiva religiosa, contando com forte apoio da Igreja, na sustentação das ações de confronto e resistência. A ideia da consciência política, fomentada por uma leitura da realidade, à luz das suas estruturas (econômica, política, ideológica), e que se articulava em termos de vincular a teoria à prática, foi mobilizada pela Teologia da Libertação. Assim, a "era movimentista" (Gohn, 2011), sob a inspiração desse movimento eclesial (Teologia da Libertação), fomentou e mobilizou e sustentou, pela Igreja, muitos movimentos sociais, como no caso dos movimentos agrários em Rondônia.

A resistência e as mobilizações produzidas pelas organizações do campo, nas décadas de 1970 e 1980, conjugavam, entrementes, uma série de fatores e determinantes. Eram o resultado da luta por sobrevivência, uma luta por inclusão, perante os desmandos do Estado e seus projetos, resultante dos acúmulos de experiências pretéritas de organização (regiões 
de origem), consciência política e ideológica fomentada por vínculos comunitários e religiosos etc.

Assim, a conjunção de fatores externos, associados a uma consciência da realidade, sob o impacto dos contextos econômicos e políticos regionais, traduzia-se em "oportunidades políticas", de mobilização e organização, mínimas e necessárias, para o enfrentamento e conquistas dos interesses, em maior ou menor grau, coletivizados. O programa de colonização, como uma medida política estrutural, eivada de contradições externas, propiciou uma reação, sobretudo naquilo que afetava as perspectivas individuais. Em grande parte, foi uma mobilização autônoma, sendo que o enfrentamento de início pautava-se pela sobrevivência ante o adversário próximo (jagunços, grandes grileiros, madeireiros).

Em pouco tempo, incorporou-se uma reação contra o Estado, omisso na solução do problema agrário e ativo na repressão policial e judicial. No entanto, essa reação também comporta efeitos provenientes da conjuntura externa, não só pelo constrangimento sofrido, mas também nas interações de apoio e alianças às ações concretas. E quando essa mobilização, em certo grau, é capturada pelo Estado, em boa medida ela se reveste de componentes estigmatizados no paternalismo e clientelismo estatal.

No campo das análises das oportunidades, há que pôr em debate, ainda, a realidade histórica do campesinato. Como já se disse, a motivação da defesa da posse de um pedaço de terra, onde pudesse plantar e conviver com sua família, traduzia para o camponês a própria reconstrução de seu imaginário social. Isso porta uma significância fundamental para esse colono-migrante, porque compõe o que ele nutriu como sonho.Assim,como forma de subsistência, sua luta inicial não será pela propriedade de terra do ponto de vista jurídico. Aqui reside, inclusive, a diferença entre a propriedade vista como terra de lucro, para o empreendedor rural, o latifundiário, e como espaço de trabalho, convivência, produção e sustento, na lógica camponesa.

Percebe-se, pois, que não se trata necessariamente de uma luta revolucionária, mas luta por existência, agregando um modo de vida e de produção. Não se coloca aqui a conquista do poder, muito menos do Estado. Não há um projeto alternativo de organização social. O que se defende, 
na forma de luta e resistência, é seu modo e condição de vida, de forma diferente, dissonante, portanto, do outro modo de vida fundado nos moldes da reprodução capitalista (Ianni, 2009). Nesse compasso, é discutível, entretanto, a categorização do campesinato como classe "primitiva" ou socialmente inferior.

Nesse aspecto, as demandas dos colonos-migrantes, nas décadas de 1970-1980, sinalizam para outra dimensão de luta pela terra, diferente do que ocorria no sul e sudeste do Brasil. Essa luta, estabelecida em áreas de fronteiras de expansão, de Projetos de colonização, não pode ser esvaziada de seu conteúdo político. Por isso, insurge-se contra uma leitura que reduz os fatores determinantes de enfrentamento e resistência a fatores meramente econômicos, como se fosse apenas o resultado de um enfrentamento entre o desenvolvimento e o atraso, entre os grandes empreendimentos e a economia de subsistência, entre posseiros e povos tradicionais.

Encerrar a discussão nesse enquadramento teórico é reduzir a perspectiva do debate. Seria o mesmo que ignorar ou passar ao largo das implicações sociais, culturais, da condição camponesa. Ainda que não se proponha à tarefa de organizar uma sociedade diferente, essa condição camponesa representa a um só tempo - e por sua capacidade de agir - as contradições do modelo político e econômico projetado, como também acenam, na forma de "metáfora do outro mundo", para o campo da produção, das relações sociais e da forma de convivência/existência na terra (Ianni, 2009). 
Nota-se, pois, que, na fronteira entre o capitalismo agrário e o modo de produção camponês ${ }^{15}$, há um confronto que subsiste ou se recria, na forma de insurgência, fazendo as reivindicações e lutas adquirirem um outro sentido. Nesse sentido, reflete Octávio Ianni, para explicitar as potencialidades inerentes a essa condição camponesa:

A reivindicação principal do campesinato é a posse e o uso da terra. Luta para preservar, conquistar ou reconquistar o seu objeto e meio básico do trabalho e vida. Em face da acumulação originária, ou do desenvolvimento extensivo e intensivo do capitalismo no campo, o camponês luta pela terra. Reage à sua expulsão do lugar em que constrói a sua vida. E essa luta frequentemente adquire conotação revolucionária. Por um lado, o camponês resiste à proletarização no campo ou na cidade. E isso é contrário ao funcionamento do mercado de força de trabalho, aos fluxos e refluxos do exército industrial de reserva, à subordinação real

\begin{abstract}
${ }^{15}$ Muitas são as abordagens sobre o modo de produção camponês. Via de regra, o debate evoca algumas correntes, como a que sustenta a existência de um modo de produção camponês, alternativo ao modo de produção capitalista (Velho, 1972). O fato de existir, no Brasil, a herança de um "capitalismo autoritário", ambiguamente forjaria esse modo de produção camponês, em uma perspectiva funcional ao processo de acumulação. Sob outro enfoque, José de Souza Martins (1975) sustenta haver na "frente de expansão", um determinado modo de produção camponesa, fundado nas experiências territoriais. Já na "frente pioneira”, prevaleceria, hegemonicamente, o modo de produção capitalista, que acaba subordinando as relações, recriando novas relações de acumulação. Para José Graziano da Silva (1978), o camponês pátrio é surgido do próprio capitalismo de produção. Ele emerge como resultado desse modo de produção capitalista que moderniza conservando as velhas estruturas. Assim, o camponês acaba sendo proprietário apenas formal dos meios de produção. Sua sobrevivência é tolerada e assegurada apenas para servir aos propósitos da classe hegemônica. Na perspectiva de Ploeg (2006), o modo de produção camponês funda-se na "condição camponesa", isto é, em condições de promover a autonomia, meios de sobrevivência e dignidade, frente ao trabalho dependente e subserviente. Por isso é um processo dinâmico e contínuo de construção. Tal modo de produção, enfim, articula-se com as relações sociais, com uma nova forma de perceber a natureza do trabalho e dos recursos disponíveis. Nesse modo de produção camponesa, tanto os recursos sociais quanto os materiais representam uma unidade orgânica, que são controlados pelos próprios envolvidos no processo de trabalho (controle camponês). Para os movimentos sociais do campo no Brasil, o modo de produção camponesa parte do reconhecimento da diversidade camponesa e de seus modos de ser, criar, fazer e viver. Em processo de construção, avança-se igualmente nas pautas das diferentes formas de conviver com a terra, florestas e águas (territorialidades), na inclusão das questões de gênero e geracional, da alimentação com qualidade (soberania alimentar) e outras soberanias: energética, genética e hídrica, sobretudo. Considera, em perspectiva dialética, o agronegócio como seu principal adversário, pela manipulação do capital financeiro, acumulação de terras, agrotóxicos e destruição ambiental. Para maiores aprofundamentos, consultar as produções disponibilizadas pelo Movimento dos Pequenos Agricultores (MPA) e materiais de Redes de Agroecologia.
\end{abstract}


do trabalho ao capital. Por outro, a luta pela terra impede, ou dificulta, a monopolização da terra pelo capital, sua transformação em propriedade mercantil, o desenvolvimento extensivo e intensivo do capitalismo na agricultura. Nessas duas perspectivas, o movimento camponês adquire dimensão nacional e põe em causa os interesses prevalecentes no governo, no Estado. Um dos componentes estruturais da ordem burguesa é a burguesia agrária, a indústria agrícola, a produção de valor na agricultura. Na medida em que esse elemento da ordem burguesa se vê bloqueado em seu funcionamento ou expansão, coloca-se em pauta um problema para as classes dominantes, o bloco de poder. (Ianni, 2009, p, 142).

Mesmo compreendendo ser, esta leitura, uma importante chave de compreensão acerca dos contextos que compõem as "oportunidades políticas" nas formas de lutas dos movimentos sociais do campo, há que trazer à baila que, além de econômicas, as formas de opressão são também culturais e sociais, além de políticas.

$\mathrm{O}$ "discurso da integração" nunca esteve tão em voga quanto atualmente, no sentido de propor a "adequação", nos modos de produção e cultura camponesa. A “assimilação", como por osmose, captura o sentido da terra, da posse e do trabalho, como produto material e simbólico de pertença. A inserção, cada vez mais estimulada, do homem e da mulher do campo ao mundo do agromercado implica cada vez mais o desafio às formas e condição camponesas, em sua dimensão de ser, criar, fazer e relacionar. Desenha-se, pois, um campo de disputa, onde a imposição pela integração busca eliminar as possibilidades de resistência e as perspectivas de mudança.

Fica exposto, assim, que há um conjunto de situações, externas ou incorporadas, que dinamizam as possibilidades, seja de intervenção, seja de mobilização, por parte dos movimentos sociais do campo. No fundo, há um risco generalizado, sentido ou não, quando os setores sociais do campo se orientam pela mediação política ou institucional, como recriação de um novo "espaço público" de debate e intervenção. Em maior ou menor grau, por força conjuntural expressa nas oportunidades políticas, a ação dos movimentos transita ou oscila entre a captura (absorção) e o enfrentamento 
instrumental elevado a um grau extremo, ante o imperativo das demandas ou como resposta às repressões.

Ondetti (2006), nesse sentido, analisa que, em muitas circunstâncias, a repressão, a criminalização e a violência contra os movimentos sociais acabam potencializando o próprio desenvolvimento da ação coletiva. Isso fica claro, em alguns casos, como Corumbiara, Eldorado dos Carajás, assassinato da Ir. Doroty, quando tais acontecimentos, pela repercussão que alcançaram, geraram constrangimento no governo federal, levando-o inclusive a medidas e políticas que não estavam na agenda governamental. E isso, por vias diretas ou indiretas, acaba levanto ao aumento tanto do processo das ocupações, como repertório próprio, como da reinserção política dos movimentos, em um novo campo de participação e mediação.

Considerando os conflitos no campo e a mobilização das bases sociais desse setor, percebe-se uma transição das mobilizações localizadas expandindo-se para a participação em espaços públicos de maior abrangência. A participação autônoma figurada nessa perspectiva, no Estado de Rondônia, potencializou a constituição de movimentos sociais que, aos poucos, vão se estruturando e reorganizando seu repertório. Em regra, tais segmentos estão vinculados a uma estrutura nacional e constroem canais de aliança e estratégia com mediações internacionais (Redes de apoio, Entidades transnacionais, Organismos multilaterais).

Por outro lado, remanesce um setor, tido como "Independente", sem uma organização de maior envergadura, que transita da "manipulação populista" ao "clientelismo burocrático", via de regra, sob influência de situações de "coronelismo político", ainda muito evidenciado na região. Essas formas de "incorporação clientelista" retratam as conexões existentes entre uma oligarquia rural, aparelhos e organismos federais, enlaçados no poder institucional localmente instalado. A privatização do público, em tais contextos, demarca um processo histórico, em muito descrito como patrimonialismo de Estado, por Raymundo Faoro (2012). 


\subsection{MOVIMENTOS SOCIAIS E RACIONALIDADE POLÍTICA - LEGITIMAÇÃO PELO PROCEDIMENTO OU PELA PARTICIPAÇÃO: DESAFIOS}

Ante uma perspectiva transformada em tendência, que muitas vezes insiste nas homogeneizações, a análise dos movimentos sociais do campo no contexto amazônico encerra alguns desafios. Em primeiro lugar, a compreensão da realidade amazônica excede a compreensão institucional da Amazônia. Em segundo lugar, para além das narrativas oficiais, há que, num exercício de desvendar consensos impostos, localizar e permitir falar as inauditas contranarrativas dos povos e comunidades originárias, dos camponeses, uma vez que são e foram vozes de resistência e de reação contra-hegemônicas. Em terceiro lugar, contra o "silêncio das genealogias", que ignora o passado e reduz o presente a instante, demanda-se por um exercício de rupturas necessárias, sem as quais, horizonte algum será autêntico. Isso implica rever "narrativas impostas" de um passado de ajustes e não de resistências.

Dessa forma, apenas uma ótica singular, que isola o enfoque das ações coletivas, precisa ser superada. Assim como se faz imperativo superar as perspectivas que enfeixam as interpretações em conceitos universalizados. No esforço em compreender o fenômeno de atuação política dos movimentos sociais do campo, portanto, há que transcender o velho esquema de leitura "estado-sociedade civil", assim como transpor uma perspectiva meramente linear de compreensão.

Uma instigante crítica feita à questão agrária, enquanto política pública, e à Reforma agrária, enquanto procedimento ou instrumento de efetivação de tal política, tem ganhado cada vez mais espaço. Em geral, trata-se, tal crítica, de constatar que, no Brasil, não houve e nem nunca haverá reforma agrária (Navarro, 2014). Ao mesmo tempo, imprime-se uma leitura homogeneizante acerca do determinismo do "agro", enquanto evidência e símbolo do progresso, da solução dos problemas do País.

Assim, ao contrário da leitura republicana ("sem reforma agrária não há democracia”), impõe-se a narrativa de que é justamente por haver 
democracia, ampliando a necessidade de grupos e classes sociais, em âmbito urbano, que se esvaziou o conteúdo político da reforma agrária e dos interesses rurais do mundo rural. Ressalva-se, nesse aspecto a "moderna agricultura empresarial”. (Navarro, 2014, p. 714).

Diante dessa "tirania urbana", portanto, a influência do rural ou do agrário vai perdendo visibilidade social e capacidade de influir nos rumos da sociedade, resultando, pois, na incompatibilidade entre democracia e reforma agrária, uma vez que, inclusive, a manutenção das assimétricas estruturas fundiárias não representam uma ameaça à ordem democrática. Uniformiza-se, portanto, a ideia e o sentido, legitimado pelo agronegócio, de certo "apagamento do passado", com a perda de visibilidade pública da questão agrária (Navarro, 2014).

"Negar a questão agrária é negar que a terra é uma das bases do poder e dominação econômica, política e social no País" (Ramos, 2014, p. 689). O contraponto da retórica que nega a centralidade da questão agrária no Brasil sucumbe ante a realidade de que não só o Brasil tem sido o país do latifúndio, como do fato de que tal condição, sobretudo na Amazônia, é o resultado de um processo amplo de saque de bens públicos. Por isso, todo o esforço, traduzido pela "fome insaciável" da Bancada ruralista em desmontar os instrumentos públicos voltados para a Política agrária, para revogar elaborações legislativas e cassar, inclusive, direitos constitucionalizados.

Para a implementação dessa retórica de negar a persistência da questão agrária, desconsideram-se questões fundamentais, a ver com graves problemas sociais pátrios: superexploração da mão-de-obra, ausência de proteção trabalhista em grandes propriedades, como regra, contradições do modelo de produção agrícola, de costas para o mercado interno, amplificação dos conflitos agrários, grilagem ou apropriação indébita e fraudulenta de terras públicas e internacionalização planejada do solo brasileiro.

Desse prisma teórico, é possível constar que a questão agrária, mais que uma questão social, apenas, é eminentemente uma questão política por todos os lados em que possa ser observada. Muito menos, não pode ser interpretada como algo de um passado não resolvido, ou de solução impossível. Pode, sim, haver mecanismos que tente ocultar a reforma agrária por 
trás das aparências, das ambíguas categorias e das pseudoconcreticidades, conforme analisa Roberto de Paula (Paula, 2016).

$\mathrm{Na}$ análise, além de demonstrar a "insistência em permanecer", busca-se desvendar as artimanhas retóricas e políticas que definem e redefinem tais vínculos no nosso contexto histórico, socioeconômico e político, resultando naquilo que se define como projeto de colonialidade. Assim, a questão agrária está organicamente atrelada a esse processo de colonialidade, material e ideologicamente sustentado:

Os efeitos ideológicos do processo colonizador materializam-se na totalidade da negação do Outro, com a mimética imposição de um conjunto ordenado de dominação ou colonização, enlaçando a língua, a religião, a forma de pensamento e a coerção jurídica, como manifestações de um único projeto de sociedade. Há um sentido de história inacabada da Questão Agrária marcada pela permanência de relações que se estabeleceram no seio da colonização e se perenizaram como colonialidade (Quijano), demandando um esforço hercúleo de descolonização (Paula, 2016, 11).

Como se constata, a questão agrária brasileira, sucessivamente alimentada por processos de colonialismos internos, reflete ou tem reflexo na disputa política, nos fatores organizacionais do poder. Pelo poder, o latifúndio, como estrutura germinada nos processos de colonização, se mantém e, na ordenação estatal, encontra proteção, sobretudo, tutela jurídica. Logra-se, assim, a salvaguarda de interesses dos grandes proprietários em detrimento da política agrária, em prejuízo, sequestro e dilapidação de direitos mínimos, mesmo que formalmente assegurados na ordem normativo-legal, estruturados pelo próprio Estado.

No contexto amazônico, em distintos níveis, os projetos de colonização, capitaneados por políticas estatais estratégicas, mantiveram sempre um pressuposto: o ocultamento das realidades locais, de seus sujeitos históricos, ao mesmo tempo que faziam uma defesa intransigente e legitimadora das estruturas que mantivessem salvaguardadas os ditames seja 
do latifúndio atrasado, seja das empresas rurais, seja, hoje, do agronegócio e de suas agroestratégias ${ }^{16}$.

Para que se surtissem os efeitos, em dois planos, essas estratégias se consumavam: um aparato legal de conveniência, sobretudo elaborado pelas corporações de interesses, pelas bancadas patronais e pela repressão. A estratégia de tornar a questão agrária, ou a democratização da terra, poderia ser colocada, a qualquer momento, como questão de "segurança nacional", e assim impunha-se a estratégia política do medo e da perseguição. Dessa forma, sob a "ótica legítima" do Estado, a questão agrária seria sumária e historicamente reduzida e, portanto, conduzida, como uma questão de polícia, mais que de política. Enquanto isso, Estado e latifúndio se complementam.

Os movimentos sociais do campo assumem uma identidade com características diferenciadas no contexto amazônico e nos processos ocorridos no Estado de Rondônia. As condicionantes que envolvem o caso específico, portanto, carregam uma forte carga advinda daquilo que se considera, no conjunto, como projeto estrutural para a Amazônia, mas também dimensiona-se pelo contexto específico, diferenciado da colonização dirigida, no Estado de Rondônia.

Uma primeira dimensão relaciona a lógica de transformar esses "novos territórios" em ganho capitalista. E assim foram, por exemplo, os grandes projetos minerários do Pará.Uma segunda dimensão diz respeito ao papel ou função que o Estado assume e seu protagonismo. E, nesse sentido, opera-se a ideia de incorporação projetada, utilizando-se de "pioneiros" que, ao abrirem áreas não exploradas economicamente, possibilitam (projetadamente) a inserção capitalista, como ocorre na Amazônia, a maior fronteira do país.

\footnotetext{
$\overline{16}$ Conforme analistas dos programas de ocupação da Amazônia, por agroestratégias entende-se de uma série de medidas, praticamente articuladas por agências multilaterais, agentes financeiros, grandes empresas, mediados quase sempre pela ação governamental, que buscam remover os obstáculos jurídico-formais visando a expansão dos monocultivos de grãos, dos empreendimentos agropecuários, incorporando assim vastas extensões de terras a estes interesses. Constata-se também a "commoditização" dos recursos, das terras e das florestas. Para tanto vale as iniciativas em flexibilizar direitos territoriais dos povos tradicionais e indígenas, desconsiderar tratados e convenções internacionais e acelerar um processo de aniquilação de direitos atingidos e declarados na Constituição referente à questão ambiental, territorial, consultas prévias, etc. Sobre este tema: ALMEIDA, Alfredo Wagner B. de. (Org,) "Agroestratégias e desterritorialização: os direitos territoriais e étnicos na mira dos estrategistas dos agronegócios”. (ALMEIDA, 2010).
} 
Se a frente de expansão dizia respeito ao primeiro momento de ocupação do espaço (vazio demográfico), tendo como consequência um deslocamento da "população civilizada", a frente pioneira é o lugar onde se cria o "novo", novas sociabilidades, formas de organização e produção, nova racionalidade fundada na lógica do mercado e na ideia de progresso (MARTINS, 1997). Dessa forma, para Martins:

[..] o avanço da frente pioneira sobre a frente de expansão e a conflitiva coexistência de ambas é mais do que contraposição de distintas modalidades de ocupação do território. Ao coexistirem ambas na situação de fronteira, dão aos conflitos que ali se travam - entre grandes proprietários de terra e camponeses e entre civilizados, sobretudo grandes proprietários, e índios - a dimensão de conflitos por distintos projetos históricos ou, ao menos, por distintas versões e possibilidades dos projetos históricos que possam existir na mediação da referida situação de fronteira. Essa situação de fronteira é um ponto de referência privilegiado para a pesquisa sociológica porque encerra maior riqueza de possibilidades históricas do que outras sociais com interesses conflitivos, agrega a esse conflito também o conflito entre historicidades desencontradas (Martins, 1997, p.155).

Considera-se, assim, que a busca por uma racionalidade que ajude a compreender a ação coletiva dos movimentos sociais do campo incorpora todas essas discussões e fazem da abordagem uma questão característica em um contexto mais ampliado. A experiência de Rondônia, seja na implementação dos projetos de colonização (privada e pública), seja na resistência dos posseiros, da década de 1970 ou dos processos de ocupação, dos anos 1980, retratam uma especificidade e ao mesmo tempo uma diversidade, em relação às múltiplas formas de atuação, de resistência e de interação com o Estado, no espaço onde as demandas foram e são articuladas.

Ainda que se constate que a luta da ocupações e defesa das posses, dos anos 1970-1980, representava um repertório "tradicional" de enfrentamento, não há como desconsiderar sua relevância para os processos decorrentes. Nessas formas de resistência e luta, ainda que a lógica da ação 
coletiva fosse objetivada racionalmente em interesses econômicos bastante localizados (o sonho da terra própria), envolviam outros fatores, como redes de apoio e articulação, atuações cooperativas e, sobretudo, a exposição, em maior ou menor visibilidade, dos equívocos dos projetos de colonização.

Assim, os movimentos sociais, da década de 1990, ao dimensionar a necessidade de fortalecimento dos vínculos organizacionais, entendeu que era preciso "ganhar" o "espaço público", inserindo-se, estrategicamente, em uma nova arena de atuação, onde as táticas de protesto e demonstrações públicas tornassem visíveis suas reivindicações.

Por esse mesmo caminho, o movimento sindical foi incorporando dinâmicas de atuação e presença, para além do fortalecimento das próprias estruturas. Questões agregadas, como crédito, seguridade social, agricultura familiar, poderiam e deveriam ser, nessa estratégia, incorporadas à questão agrária.

Dessa forma, é pela percepção da necessidade de atuar no "espaço público", com objetivo também no recurso da opinião pública, que os movimentos sociais do campo qualificaram suas atuações. A revitalização desses movimentos sociais do campo, assim, põe em evidência, também, a vulnerabilidade política por parte do Estado, mas evidencia, sobretudo, e confronta o absurdo assimétrico da realidade do latifúndio e da grilagem que, com o aval estatal, inviabilizou a possibilidade de uma distribuição equitativa de terras e recursos, no campo em Rondônia.

Ao pôr em evidência a atualidade da questão agrária, os movimentos sociais põem abaixo esses artifícios, retóricos e imaginados, de que é justamente pelo processo de modernização democrática que tal questão tem de ser desconsiderada. Muito menos, trata-se de relegar tal questão a um refúgio inacessível, no contexto republicano.

A pluralidade de demandas, materializadas pela urbanização excessiva, não pode servir de "cortina de fumaça" para os seculares problemas sociais, ao contrário, os desvela e amplifica. Não há, pois, como negar o caráter patrimonialista que permeia nossa constituição social, as ambiguidades e contradições que recobrem a relação de poder e a corporativização de interesses, alojados nas estruturas do Estado brasileiro. 
Uma autêntica racionalidade política, a ser construída pelo protagonismo dos movimentos sociais do campo, necessitará desarmar as armadilhas montadas que, potencialmente, poderiam sequestrar as possibilidades democráticas da participação e da intervenção. Em absoluto, a opção em cruzar a fronteira, em um espaço de relação/interação, significa buscar a legitimidade pelo procedimento. Em outros termos, não se trata de cumprir regras burocráticas, trilhar pelas margens da legalidade, mas de implementar condições de produzir impactos concretos, de justiça e bem-estar social aos povos do campo. Por isso, uma atuação que se norteie pela transformação das perversas estruturas fundiárias, é inexorável.

Caberia, pois, aos movimentos sociais do campo, essa tarefa política de superação de um modelo de participação democrática centrada no procedimento. Remete-se também à superação de um modelo democrático, pela representatividade eleitoral, "Estado-cêntrica", bem como uma ressignificação da democracia em termos de uma cidadania ampliada, mais que regulada. Não é, pois, ocultando as estruturas organizacionais, enquanto fatores de poder, politicamente instalados, que a democracia se amplia. Há, portanto, um cenário de grandes potencialidades, que caracterizam os movimentos sociais do campo, em seus processos de diálogo e participação, como requisito essencial de uma leitura e reconstrução democrática.

\section{CONCLUSÃO}

A luta pela terra, no contexto brasileiro, e sobremaneira, no contexto da colonização da Amazônia, é uma luta eminentemente política, seja em sua dimensão positiva, enquanto ação transformadora e instrumental, por parte dos movimentos sociais, seja pelas ostensivas tentativas de domesticação e transformação dessas lutas, por parte do Estado.

O fenômeno da colonização, inclusive, sistematiza as condições tanto no plano econômico e político, quanto no plano social e jurídico, que contextualizaram tal processo histórico. Se, por um lado, a colonização em si representou, em tese e prática, um modelo de inserção da Amazônia na dinâmica de expansão do capital, por outro lado, a ação coletiva 
dos movimentos sociais, em muito representou seu contraponto. A forma dirigida de ocupação, como maneira de legitimar ou perpetuar estruturas de apropriação e dominação, foi enfrentada em vários níveis, pelos colonos-migrantes, desvelando mitos, narrativas e imaginários impostos, principalmente sob o mote do desenvolvimento e da integração nacional.

Ausentados, os povos originários, indígenas, quilombolas, ribeirinhos e seringueiros, sofreram na pele e no sangue a imposição do desconhecimento, do esquecimento e da interdição de mínimos direitos. Reordena-se, assim, a sociedade colona, com as mesmas bases de sempre, ou seja, da desigualdade, do saque e da ação espoliativa dos povos e comunidades tradicionais.

Em outro campo, buscou-se, tantas vezes, a luta por terra e direitos dentro da ordem instituída. Percebia-se, aliás, que a única forma de dar legitimidade a essa luta seria sob a tutela do Estado. Dessa forma, tornou-se oportuno, para esse mesmo Estado, esvaziando o conteúdo político da demanda agrária, manter as coisas como estavam, acomodando os interesses antagônicos, prevalentes e hegemônicos no seio do mesmo Estado. Por mais paradoxal que pareça, revelava-se, assim, ambígua e historicamente, uma domesticação funcional de conflitos estruturais, uma maneira de subalternizar as relações, sempre na lógica do capital.

Assim, sendo a questão do acesso à terra uma questão estrutural, na história econômica, social e política brasileira, é na instrumentalidade do Estado que tal questão se totaliza. Em outras palavras, a questão agrária, na dinâmica da colonização, revela o Brasil em sua constituição e reconstituição social, econômica e política. É igualmente nesse contexto que os movimentos sociais do campo são compreendidos e se reconhecem, tanto no plano das condicionantes sociais e políticas quanto culturais, em que se desenvolvem.

É no processo de resistência, organização e lutas concretas, por parte dos grupos e movimento sociais do campo, que esses sujeitos coletivos vão dando conta da consciência da subalternidade, que a eles se revela. Por outro lado, tais movimentos também são percebidos de forma diferente, na própria forma como se reconhecem, e na forma como o Estado os reconhece. Via de regra, para o Estado, representam uma ameaça à ordem, uma 
subversão à lei, uma provocação e, por isso, a ideia de arranjos e composições, como formas de domesticar ou despolitizar tais ações.

Seja como for, essa dinâmica põe em questão pelo menos dois debates: de um lado, a percepção de que a questão do acesso a terra, ou questão agrária, é uma questão estrutural no Brasil e não se resolve sob o dirigismo ou tutela paternalista e compensatória do Estado, e, de outro lado, a questão do protagonismo e condições colocadas aos próprios movimentos sociais do campo.

Por sua ação, sinalizam a possibilidade de ruptura à ordem instituída? Podem resolver as estruturais e desiguais injustiças, perante o império e a retórica da ordem e da lei? Amoldam-se por meio de arranjos políticos possíveis, afetados sempre pelas condições políticas vigentes, e, assim, reféns do contexto?

No caso específico e objeto do presente estudo, verificou-se que a questão agrária, no âmbito do processo de colonização, e a questão da efetiva participação dos movimentos sociais no Estado são questões elementares para rediscutir o Brasil e para compreender as dinâmicas socioterritoriais, econômicas e políticas em Rondônia.

De tal forma, a leitura dessa realidade tecida por meio de uma teia complexa de vínculos desafia consensos, mobiliza contextos e ativa a consciência crítica, para além da observação das aparências. Cabe uma responsabilidade aos movimentos sociais do campo, antes de tudo, a superação de uma compreensão colonizada da realidade, não importando de onde surja o colonizador. Compete, também, aos agentes dos movimentos sociais, uma percepção do dinamismo em movimento, que recupere as fontes, mas que ajude a enxergar as margens, a fim de que se mantenha o horizonte em perspectiva emancipatória.

Nesse sentido, a história das lutas agrárias supõe uma consciência coletiva do protagonismo dos movimentos sociais, sem vedetismo narcísico, muito menos ingenuidade histórica e política. Estar em movimento, portanto, sinaliza para um esforço incansável contra as rotineiras formas de exploração e toda sorte de constrangimentos estruturais. 


\section{REFERÊNCIAS}

ABERS, Rebeca; Von Bülow, Marisa. Movimentos sociais na teoria e na prática: como estudar o ativismo através da fronteira entre Estado e sociedade? Sociologias. Porto Alegre, ano 13, n.28 p. 52-84, 2011.

ABERS, Rebeca; SERAFIM, Lizandra; TATAGIBA, Luciana. Novas relações Estado-sociedade no governo federal brasileiro. Repertórios de participação em um Estado heterogêneo. In: ENCONTRO ANUAL DA ANPOCS, 35. Anais... 2011.

ABRAMOVAY, Ricardo. Paradigmas do capitalismo agrário em questão. 3. ed. São Paulo: Edusp, 2007.

ACERVO ISA. Viagem ao Remoto País dos territórios. Revista Visão, 7 out.1974, p. 25 32. Disponível em: <https://acervo.socioambiental.org/acervo/noticias/viagem-ao-remoto-pais-dos-territorios>. Acesso em: 10 jan. 2018.

ALBERTI, Verena. Manual de história oral. 2.ed. Rio de Janeiro: FGV, 2004.

ALLEGRETTI, Mary Helena. A construção social de políticas ambientais: Chico Mendes e o Movimento dos Seringueiros. 2002. Tese (Doutorado) - PPG em Desenvolvimento Sustentável e Gestão de Política Ambiental. Universidade Nacional de Brasília UNB, 2002.

ALMEIDA, Alfredo Wagner. 2010. Agroestratégias e desterritorialização: os direitos territoriais e étnicos na mira dos estrategistas dos agronegócios. In: A. ALMEIDA et alli. Capitalismo globalizado e recursos territoriais: fronteiras da acumulação no Brasil contemporâneo. Rio de Janeiro: Lamparina, 2010. p. 101-143.

ALMEIDA, Alfredo Wagner Berno de. Universalização e Localismo-Movimentos Sociais e crise dos padrões tradicionais de relação política na Amazônia”. ABRA-Associação Brasileira de Reforma Agrária. Ano 19, n. 1. abril/jun. de 1989. Abra (Associação Brasileira de Reforma Agrária), p. 4-7

ALONSO, Ângela. As teorias dos movimentos sociais: um balanço do debate. Revista Lua Nova, São Paulo. n.76, 2009. Disponível em: <http://www.redalyc.org/articulo. oa? id=67313619003>. Acesso em 23 jun. 2017.

AMARAL, Januário. Mata virgem: terra prostituta. São Paulo: Terceira Margem, 2004.

ASSELIN, Victor. Grilagem: corrupção e violência em terras do Carajás. Petrópolis: Vozes/ CPT, 1982.

AUBERTIN, Catherine. (Org.). Fronteiras. Brasília: Ed. Universidade de Brasília, 1988.

AVRITZER, Leonardo. Impasses da democracia no Brasil. Rio de Janeiro: Civilização Brasileira, 2016. 
BALLESTRIN, Luciana. Para transcender a colonialidade. In: Revista IHU online (Revista Impressa). São Leopoldo, n.431, Ano XIII. p. 40-41, nov. 2013.

BARBOSA, Adelto Rodrigues. Histórias silenciadas, formas de resistência na ocupação do município de Urupá: a cultura da colonização. 2017. Dissertação (Mestrado em História) PPG em História e Estudos culturais, UNIR, 2017.

BECKER, Berta Koiffmann. Amazônia. São Paulo: Ática, 1991

BECKER, Bertha Koiffmann. A fronteira em fins do século XX: oito proposições para um debate sobre a Amazônia. In: BECKER, Bertha K.; MIRANDA, Mariana Helena P. de; MACHADO, Lia Osório. Fronteira amazônica: questões sobre a gestão do território. Brasília: Editora Universidade de Brasília; Rio de Janeiro: Editora Federal do Rio de Janeiro, 1990.

BOSI, Ecléa. O tempo vivo da memória: Ensaios de Psicologia social. São Paulo: Ateliê Editorial, 2003.

BOURDIEU, Pierre. O poder simbólico. Trad. Fernando Tomaz. Rio de Janeiro: Ed. Bertrand Brasil S.A, 1989, p. 163.

BOURDIEU, Pierre. Sobre o Estado. Trad. Rosa Freire d'Aguiar. São Paulo: Companhia das Letras, 2014.

BOURDIEU, Pierre. 1998. O capital social - notas provisórias. In: CATANI, Afrânio Mendes e NOGUEIRA, Maria Alice (Orgs.). Escritos de Educação. Petrópolis: Vozes, 1998.

BRASIL. Decreto n. 91.766, de 10 de outubro de 1985. Aprova o Plano Nacional de Reforma Agrária - PNRA, e dá outras providências. Diário Oficial da União, Brasília, 11 de outubro de 1985.

BRASIL. Lei no 8.629, de 25 de fevereiro de 1993. Dispõe sobre a regulamentação dos dispositivos constitucionais relativos à reforma agrária, previstos no Capítulo III, Título VII, da Constituição Federal. Diário Oficial da União, Brasília, 26 de fevereiro de 1993.

BRASIL. Lei no 11.952 de 25 de junho de 2009. Dispõe sobre a regularização fundiária das ocupações incidentes em terras situadas em áreas da União, no âmbito da Amazônia Legal; altera as Leis nos 8.666, de 21 de junho de 1993, e 6.015, de 31 de dezembro de 1973; e dá outras providências. Diário Oficial da União, Brasília, 26 de junho de 2009.

BRASIL. Lei no 13.465 de 11 de julho de 2017. Dispõe sobre a regularização fundiária rural e urbana, sobre a liquidação de créditos concedidos aos assentados da reforma agrária e sobre a regularização fundiária no âmbito da Amazônia Legal; institui mecanismos para aprimorar a eficiência dos procedimentos de alienação de imóveis da União; altera as Leis nos 8.629, de 25 de fevereiro de 1993, 13.001, de 20 de junho de 2014, 11.952, de 25 de junho de 2009, 13.340, de 28 de setembro de 2016, 8.666, de 21 de junho de 1993, 6.015, de 31 de dezembro de 1973, 12.512, de 14 de outubro de 2011, 10.406, de 10 de janeiro de 2002 (Código Civil), 13.105, de 16 de março de 2015 (Código de Processo Civil), 11.977, de 7 de julho de 2009, 9.514, de 20 de novembro de 1997, 11.124, de 16 de junho de 2005, 
6.766, de 19 de dezembro de 1979, 10.257, de 10 de julho de 2001, 12.651, de 25 de maio de 2012,13.240, de 30 de dezembro de 2015, 9.636, de 15 de maio de 1998, 8.036, de 11 de maio de 1990, 13.139, de 26 de junho de 2015,11.483, de 31 de maio de 2007, e a 12.712, de 30 de agosto de 2012, a Medida Provisória no 2.220, de 4 de setembro de 2001, e os Decretos-Leis nos 2.398, de 21 de dezembro de 1987, 1.876, de 15 de julho de 1981, 9.760, de 5 de setembro de 1946, e 3.365, de 21 de junho de 1941; revoga dispositivos da Lei Complementar no 76, de 6 de julho de 1993, e da Lei no 13.347, de 10 de outubro de 2016; e dá outras providências. Diário Oficial da União, Brasília, 12 de julho de 2017.

BRESSER-PEREIRA, Luiz Carlos. O paradoxo da esquerda no Brasil. In: Revista Novos Estudos CEBRAP, São Paulo, n.74, p. 25-45, mar.2006. Disponível em: <http://www. scielo.br/scielo.php?script=sci_arttext\&pid=S0101-33002006000100003 >. Acesso em: 10 jan. 2018.

BRUNO, Regina. Guardiões da reforma agrária: servidores públicos e técnicos em defesa de uma reforma agrária durante a ditadura militar do Brasil. Tempos Históricos, v. 16, 2012, 2. semestre.

BRUNO, Regina. Movimento Sou Agro: marketing, habitus e estratégias de poder do Agronegócio. ENCONTRO ANUAL DA ANPOCS, 36. Águas de Lindóia. Disponível em: <http://anpocs.org/index.php/encontros/papers/36-encontro-anual-da-anpocs/gt-2/gt16-2/8027-movimento-sou-agro-marketing-habitus-e-estrategias-de-poder-do-agronegocio?path=36-encontro-anual-da-anpocs/gt-2/gt16-2>.Acesso:10jan.2018.

CARTER, Miguel. Desafiando a desigualdade: contestação, contexto e conseqüências. In: CARTER, Miguel. (Org.). Combatendo a desigualdade social: o MST e a reforma agrária no Brasil. São Paulo: Editora Unesp, 2010.

CARVALHO, Horácio Martins de. O campesinato contemporâneo como modo de produção e como classe social. Curitiba, 2012. Disponível em: <www.landaction.org/IMG/rtf/ Os-limites-da-resistencia-social-camponesa.rtf>. Acesso: 10 jan. 2018.

CASSIRER, Ernst. O mito do Estado. Trad. Álvaro Cabral. São Paulo: Códex, 2003.

CASTILHO, Alceu Luís. Partido da Terra: como os políticos conquistam o território brasileiro. São Paulo: Editora Contexto, 2012.

CASTRO, Camila Penna de. Conexões e controvérsias no Incra de Marabá: o Estado como ator heterogêneo. 2013. Tese (Doutorado em Sociologia) - Departamento de Sociologia da Universidade de Brasília, 2013.

CASTRO, Josué de. Geografia da fome - A fome no Brasil. Rio de Janeiro: O Cruzeiro, S.A, 1946.

CASTELLS, Manuel. Redes de indignação e esperança: movimentos sociais na era da internet. Trad. de Carlos Alberto Medeiros. Rio de Janeiro: Zahar, 2013. 
CHAGAS, Afonso Maria das. Emergência dos direitos territoriais frente ao direito de propriedade fundiária: do colonialismo jurídico à pluralidade de direitos. 2012. Dissertação (Mestrado em Direito) - PPG em Direito da Universidade Vale dos Sinos - UNISINOS. São Leopoldo, 2012.

CLEPS JUNIOR, João. Descaminhos da reforma agrária no contexto das reformas neoliberais e da crise institucional no Brasil. In: NERA - Núcleo de Estudos, Pesquisas e Projetos de Reforma agrária. n.120, dez. 2017. Disponível em: <www.fct.unesp.br/nera >. Acesso em: 13 março 2018.

CNDH. Conselho Nacional de Direitos Humanos. Relatório de Missão: Rondônia. 2016 (Material impresso).

COIMBRA, Cláudia Conceição. Territórios em trânsito: estratégias de sobrevivência das mulheres do Acampamento Arraial da Vitória, Ariquemes. Rondônia e a instituição de seus territórios. 2015. Dissertação (Mestrado em Geografia) - Programa de Pós-Graduação em Geografia, Universidade Federal de Rondônia - UNIR. Porto Velho, 2015.

COY, Martin. Problemas atuais de colonização e desenvolvimento rural numa fronteira agrícola na Amazônia brasileira e a resposta do Estado: O caso de Rondônia. In:EMBRAPA/CPATU (Org.).SIMPÓSIO DO TRÓPICO ÚMIDO, 1. Belém. Anais... v. VI: Temas Multidisciplinares, p. 321-331. Belém,1986.

COLLINS, Patrícia Hill. Em direção a uma nova visão: raça, classe e gênero como categorias de análise. In: MORENO, Renata (Org.). Reflexões e práticas de transformação feminista. São Paulo: SOF, 2015.

CORUMBIARA. Direção de Vincent Carelli. Estúdio: Vídeo nas Aldeias. Brasil, 2009.

COSTA, Francisco de Assis. Agropecuária da Amazônia: os desafios do desenvolvimento sustentável. Belém: NAEA/UFPA, 2012.

COSTA, Francisco de Assis. Ecologismo e questão agrária na Amazônia. Belém: Sepeq/ NAEA/UFPA, 1992.

COSTA, Gleimiria Batista de. Permanência de práticas tradicionais em Reservas Extrativistas no Estado de Rondônia. 2012. Tese (Doutorado em Desenvolvimento Regional) - Universidade de Santa Cruz do Sul - UNISC, 2012.

COWELL, Adrian; RIOS, Vicente. A década da destruição. Direção Adrian Cowel e Vicente Rios, 34 min. Produção Verbo Filmes/Cit. 2010.

CPT/VÁRIOS AUTORES. Conflitos no Campo Brasil 2016. Goiânia: CPT Nacional, 2017.

CPT/VÁRIOS AUTORES - Comissão Pastoral da Terra. Conflitos no campo Brasil: 1988. Goiânia: CPT, 1989. 
CPT/RO. Comissão Pastoral da Terra - Regional Rondônia. Relatórios dos conflitos no campo no Estado de Rondônia. Porto Velho, 1991. (Material impresso)

CPT/RO. Comissão Pastoral da Terra - Regional Rondônia. Atas e Relatórios. Porto Velho, 1989. (Material impresso)

CRUZ, Montezuma. O latifúndio armado e a bala contra Agenor. 2007. Disponível em: $<$ http://www.tudorondonia.com/noticias/o-latifundio-armado-e-a-bala-contra-agenor-montezuma-cruz-,3918.shtml>. Acesso em: 15 jan. 2018.

CUNHA, Sílvio Rodrigus Persivo. O Xadrez da Terra. Um Estudo Sobre a Colonização Dirigida em Rondônia.1985. Dissertação de Mestrado. Belém: UFPA. Ano de Obtenção: 1985.

CUNHA, Eliaquim Timóteo; MOSER, Lilian Maria. Os Projetos de Colonização em Rondônia. In: Revista Labirinto, Ano X, n. 14, dez. 2010. Disponível em: <www.periodicos.unir.br/index.php/LABIRINTO/article/download/938/922>. Acesso em: 12 dez. 2017.

DAL MASO, Mansueto. Movimentos Sociais: a longa viagem para o mesmo lugar. 2004. 300f. Tese (Doutorado em Filosofia e Ciências Sociais)- Programa de Pós-Graduação em Filosofia e Ciências sociais, Universidade Estadual de Campinas - UNICAMP, Campinas, 2004.

D'ARAUJO, Maria Celina. A elite dirigente do governo Lula. Rio de Janeiro: CPDOC, 2009.

DUARTE, Nestor. A Ordem privada e a Organização política nacional. São Paulo: Brasiliense, 1966.

ENGELMANN, Solange I; GIL, Aldo Duran. A questão agrária no Brasil, a política agrária no governo Lula e a relação com o MST. In: Revista Eletrônica do CEMOP, n.2, set. 2012. Disponível em: < http://www.memoriaoperaria.org.br/revistaeletronica/solange_e_aldo_duran.pdf $>$. Acesso em: $10 \mathrm{dez} .2017$.

FAORO, Raymundo. Os donos do poder: formação do patronato político brasileiro. 16. ed. São Paulo: Globo, 2012.

FEARNSIDE, Philip Martin. Projetos de colonização na Amazônia brasileira: objetivos conflitantes e capacidade de suporte humano. Cadernos de Geociëncias, n. 2, 1989. p.7-24.

FELZKE, Lediane Fani; OLIVEIRA, Dalva Felipe de; PAULA, Jania Maria de. Memória e resistência na migraçao para a Amazônia: O caso de Nova Londrina em Ji-Paraná, Estado de Rondônia, Brasil (En línea). Mundo Agrário, v.15, n.30. Disponível em: <<http://www. memoria.fahce.unlp.edu.ar/art_revistas/pr.6495/pr.6495.pdf >>. Acesso em: 10 mar. 2018.

FERNANDES, Florestan. A revolução burguesa no Brasil. São Paulo: Globo, 2005. 
FERNANDES, Bernardo Mançano. Reforma Agrária no Brasil, para além de um projeto: uma luta permanente. In: A Questão Agrária no século XXI - escalas, dinâmicas e conflitos territoriais. São Paulo: Expressão Popular, 2015.

FERNANDES, Bernardo Mançano. Contribuição ao estudo do campesinato brasileiro: formação e territorialização do MST (1979-1999). 1999. Tese (Doutorado em Geografia) PPG Geografia, Universidade de São Paulo, 1999.

FERREIRA, Maria Madalena. Rondônia: principais fases de desenvolvimento. In: ALMEIDA SILVA, Adnilson de; NASCIMENTO SILVA, Maria das Graças; SILVA, Ricardo Gilson da Costa. (Orgs.). Colonização, território e meio ambiente em Rondônia: reflexões geográficas. Curitiba: SK Editora/Porto Velho: PPGG/UNIR, 2012.p. 31-57.

FERREIRA, Iremar Antônio. Fachos acesos na mata. 2009. Dissertação (Mestrado) - PPG em Desenvolvimento Sustentável e Meio Ambiente, Universidade Federal de Rondônia UNIR. Porto Velho, 2009.

FOUCAULT, Michel. Microfísica do Poder. Trad. Roberto Machado. Rio de Janeiro: Graal, 1979.

GERALDES, Elen Cristina et al. (Orgs.). Mídia, Misoginia e Golpe. Brasília: FAC-UNB, 2016.

GOHN, Maria da Glória. Movimentos Sociais na Contemporaneidade. Revista brasileira de Educação, Rio de Janeiro, v. 16, n. 47, maio-ago. 2011.

GOHN, Maria da Glória. Teorias dos movimentos sociais: paradigmas clássicos e contemporâneos. 11.ed. São Paulo: Edições Loyola, 2014.

GRAMSCI, Antonio. A questão Meridional. Trad. de Carlos Nelson Coutinho e Marco Aurélio Nogueira. Rio de Janeiro: Paz e Terra, 1987.

GRAZIANO DA SILVA, José. Estrutura agrária e produção de subsistência na agricultura brasileira. São Paulo: Hucitec, 1978.

GRZYBOWSKI, Cândido. Caminhos e descaminhos dos Movimentos Sociais no Campo. Petrópolis: Vozes, 1987.

GUIMARÃES, Alberto Passos. Quatro Séculos de Latifúndio. 5. ed. Rio de Janeiro: Paz e Terra, 1981.

GUIMARÃES, Juarez Rocha. Do sentimento à imaginação republicana: em busca de uma narrativa para a reforma agrária do século XXI. In: STARLING, Heloisa Maria Murgel; RODRIGUES, Henrique Estrada; TELLES, Marcela (Orgs.). Utopias agrárias. Belo Horizonte: Editora UFMG, 2008.

GUPTA, Akhil. Blurred Boundaries: the discourse of corruption, the culture of politics and the imagined state. In: SHARMA, Aradhana; GUPTA, Akhil. The Anthropology of the State: Areader. Oxford: Blackwell, 2006. p. 211-243. 
HALL, Anthony. Developing Amazonia: Deforestation and social conflict in Brazil's Carajas Programme. Manchester University Press, Manchester, UK. 1989.

HOLANDA, Sérgio Buarque de. Raízes do Brasil. São Paulo: Companhia das Letras, 1995.

HÉBETTE, Jean. Cruzando a fronteira: 30 anos de estudos do campesinato na Amazônia. Belém: EDUFPA, 2004, v. I a IV.

HENRIQUES, Maria Helena Fernandes de Trindade. A política de colonização dirigida no Brasil - um estudo de caso, Rondônia. Revista Brasileira de Geografia, v.46, n. 3/4, p. 393-423, jul./dez., Rio de Janeiro, 1984.

HONNETH, Axel. Luta por reconhecimento: a gramática moral dos conflitos sociais. Tradução de Luiz Repa. São Paulo: Ed. 34, 2003.

IANNI, Octávio. Colonização e contra-reforma agrária na Amazônia. Petrópolis: Vozes, 1979.

IANNI, Octávio. A utopia camponesa. In: WELCH, Clifford Andrew et al. (Orgs.). Camponeses brasileiros: leituras e interpretações clássicas. v. 1. São Paulo: Editora Unesp, 2009.

LAZZARINI, Sérgio. Capitalismo de Laços: os donos do Brasil e suas conexões. São Paulo: Elsevier, 2011.

LIMONGI, Fernando; FIGUEIREDO, Argelina. Bases institucionais do presidencialismo de coalizão. Lua Nova [online]. 1998, n.44, p. 81-106. Disponível em: <http://www.scielo.br/scielo.php?script=sci_arttext\&pid=S0102-64451998000200005\&lng=pt\&nrm=iso $>$. Acesso: 12 fev. 2017.

McADAM, Doug; TARROW, Sidney; TILLY, Charles. Para mapear o confronto político. Tradução de Ana Maria Sallum. In: Revista Lua Nova. n. 76. São Paulo, 2009. p. 11-48.

MARIÁTEGUI, José Carlos. Sete ensaios de interpretação da realidade peruana. São Paulo: Expressão Popular, 2010.

MARTINS, Márcio Marinho. Corumbiara, massacre ou combate? A luta pela terra na Fazenda Santa Elina. 2009. Dissertação (Mestrado em Geografia) - PPG em Geografia, Universidade Federal de Rondônia - UNIR. Porto Velho, 2009.

MARTINS, José de Souza. Fronteira: a degradação do Outro nos confins do humano. São Paulo: Hucitec, 1997.

MARTINS, José de Souza. A reprodução do capital na frente pioneira e o renascimento da escravidão no Brasil. In: Tempo Social, Revista de Sociologia da USP, v. 6. n.1-2. jan. 1995.

MARTINS, José de Souza. O tempo da fronteira: retorno à controvérsia sobre o tempo histórico da frente de expansão e da frente pioneira. In: MARTINS, José de Souza. Fronteira: A degradação do outro nos confins do trabalho. São Paulo: Editora contexto, 2. ed. 1997. p.131-179. 
MARTINS, José de Souza. O poder do atraso: ensaios de sociologia da história lenta. São Paulo: Editora Hucitec, 1994.

MARTINS, José de Souza. Lutando pela terra: índios e posseiros na Amazônia Legal. In: Revista de Ciências sociais, v. 11, n. 1-2. Fortaleza, 1980. p. 7-27.

MARTINS, José de Souza. Capitalismo e tradicionalismo. São Paulo: Pioneira, 1975.

MARTINS, José de Souza. Do PT das lutas sociais ao PT do Poder. São Paulo: Contexto, 2016.

MASCARO, Alysson Leandro. Estado e forma política. São Paulo: Boitempo, 2013.

MESQUITA, Helena Angélica. Corumbiara: o massacre dos camponeses. Rondônia (1995). 2001. Tese ( Doutorado em Geografia Humana) -Programa de Pós-Graduação em Geografia Humana, Universidade de São Paulo-USP, 2001.

MONTEIRO, Rodrigo Paranhos. De fronteira a território - Agricultura familiar na Amazônia Ocidental: o caso da formação da bacia leiteira em Ouro Preto do Oeste, Rondônia. Dissertação ( Mestrado) - PPG em Desenvolvimento, Agricultura e Sociedade, Universidade Federal Rural do Rio de Janeiro, 2004.

MINDLIN, Betty. Diários da floresta. São Paulo: Editora Terceiro Nome, 2006, 245 p.

MOSER, Lilian Maria; ERNESTO, Eduardo Servo. A migração para Rondônia (Brasil) pós década de setenta: um olhar a partir dos estudos culturais. Revista de História da UEG, Anápolis/GO, v. 5, n.1. jna./jul. 2016. Disponível em: <http://www.revista.ueg.br/index. php/revistahistoria/article/view/4827>. Acesso: 12 jan. 2018.

MURTA, Raíssa de Oliveira. Ethos Camponês e espaço rural periférico: (des)encaixes frente à legislação florestal brasileira. 2014. Dissertação (Mestrado) - PPG em Extensão rural, Universidade Federal de Viçosa, 2014.

NAVARRO, Zander. Por que não houve (e nunca haverá) reforma agrária no Brasil? In: BUAINAIM, Antônio; ALVES, Eliseu; SILVEIRA, José Maria da; NAVARRO, Zander. O mundo rural no Brasil do século 21: a formação de um novo padrão agrário e agrícola. Brasília: Embrapa, 2014, p. 695-694.

NEVES, Delma Pessanha. Questão agrária: projeções societais em confronto. Revista Texto e Debates, Boa Vista, n.31, p. 79-106, jan./jun., 2017.

NUNES, Victor leal. Coronelismo, enxada e voto: o município e o regime representativo no Brasil. Rio de Janeiro: Companhia das Letras, 1947.

NOBREGA, Renata da Silva. "Entra na roda": história, cotidiano e mobilidades em Rondônia. Tese (Doutorado em Sociologia) - PPG em Sociologia, Universidade Estadual de Campinas, Campinas, 2016. 
OLIVEIRA, Ricardo Costa de. O silêncio das genealogias: classe dominante e Estado no Paraná. 2000. Tese (Doutorado em Sociologia) - PPG em Sociologia, Universidade Estadual de Campinas, Campinas, 2000.

OLIVEIRA, Ariovaldo Umbelino de. A geografia das lutas no campo. São Paulo: Contexto, 1994.

OLIVEIRA, Ariovaldo Umbelino. Integrar para (não) entregar: políticas públicas e Amazônia. Campinas/SP: Papirus, 1988.

OAN - Ouvidoria Agrária Nacional. Atas e Relatórios, 2016 e 2017 (material impresso).

OLIVEIRA, Francisco; BRAGA, Ruy; RIZEK, Cibele. Hegemonia às avessas. São Paulo: Boitempo, 2010.

OLSON, Mancur. A lógica da Ação coletiva: os benefícios públicos e uma teoria dos grupos sociais. Tradução de Fábio Fernandez. São Paulo: Ed. Universidade de São Paulo, 1999.

ONDETTI, Gabriel. Land, Protest and Politics: the landless movement and the struggle for agrarian reform in Brazil. Pennsylvania: University Press, 2008.

ONDETTI, Gabriel. 2006. Repression, opportunity, and protest: Explaining the take off of Brazil's Landless Movement. Latin American Politics and Society, v. 48, Issue 2, p. 61 - 94 , 2006.

ONDETTI, Gabriel; WAMBERGUE, Emmanuel; AFONSO, José Batista Gonçalves. De posseiro a Sem-Terra: o impacto da luta pela terra do MST no Pará. In: CARTER, Miguel. (Org.). Combatendo a desigualdade social: o MST e a reforma agrária no Brasil. Tradução de Cristina Yamagami. São Paulo: Editora UNESP, 2010.

PAULA, Roberto de. Questão agrária e insurgência na América Latina. 2016, 186f. Tese (Doutorado em Direito) - Programa de Pós-Graduação em Direito, Universidade Federal do Paraná - UFPR, Curitiba, 2016.

PORTELLI, Alessandro. História oral como arte da escuta. Tradução de Ricardo Santhiago. São Paulo: Letra e Voz, 2016.

PERDIGÃO, Francinete; BASSEGIO, Luis. Migrantes amazônico. Rondônia: a trajetória da ilusão. São Paulo: Ed. Loyola, 1992

PALMEIRA, Moacir. Burocracia, política e reforma agrária. In: MEDEIROS, Leonilde et al. Assentamentos Rurais: uma visão multidisciplinar. São Paulo: Editora Unesp, 1994. p. 49-69.

PENNA, Camila; ROSA, Marcelo C. Estado, movimentos e reforma agrária no Brasil. Revista Lua Nova - Revista de Cultura e Política, n. 95, São Paulo, maio/ago., 2015, p. 57-85. 
PLOEG, Jan Douwe van der. O Modo de produção camponesa revisitado. In: SCHNEIDER, Sérgio. A diversidade da agricultura familiar. Porto Alegre: UFRGS, 2006. p. 13-56.

PORTO-GONÇALVES, Carlos Walter. A Reinvenção dos Territórios: a experiência latino-americana e caribenha. CLACSO, Consejo Latinoamericano de Ciencias Sociales, 2006. Disponível em: <http://bibliotecavirtual.clacso.org.ar/clacso/gt/20101019090853/ 6Goncalves.pdf2006>. Acesso em: 10 jan. 2018.

PRADO JÚNIOR, Caio. Formação do Brasil contemporâneo. Belo Horizonte: Itatiaia; São Paulo: Publifolha, 2000.

RAMOS, Pedro. Uma história sem fim: a persistência da questão agrária no Brasil contemporâneo. In: BUANAIN, Antônio Márcio; ALVES, Eliseu; SILVEIRA, José Maria da; NAVARRO, Zander. O mundo rural no Brasil do Século XXI: a formação de um novo padrão agrário e agrícola. Brasília/DF: Embrapa, 2014.

REIS, Elisa Pereira. Brasil: Cem anos de questão agrária. Revista de Ciências Sociais, Rio de Janeiro, v. 32, n. 3, p. 281-301, 1989.

REIS, Elisa M. P. Elites Agrárias, State-Building e Autoritarismo. Dados, v. 25, n.3, p. 331-348, 1982.

RENNÓ, L. R. Estruturas de oportunidade política e engajamento em organizações da sociedade civil: um estudo comparado sobre a América Latina. Revista de Sociologia e Política, n. 21, p.71-82, nov. 2003.

RIBEIRO, Ana Clara Torres. Por uma Sociologia do presente: ação, técnica, espaço. Rio de Janeiro: Letra Capital, 2013.

RIBEIRO, Djamila. O que é lugar de fala? Belo Horizonte: Editora Letramento, 2017.

RICCI, Rudá. Lulismo - da era dos movimentos sociais à Ascenção da Nova classe média brasileira. Rio de Janeiro: Contraponto, 2013.

ROSA, Marcelo. O Engenho dos Movimentos: reforma agrária e significação social na zona canavieira de Pernambuco. Rio de Janeiro: Garamond, 2011.

SANTOS, Carlos. A Fronteira do Guaporé. Porto Velho/RO: EDUFRO 2001.

SANTOS, José Vicente Tavares de. Matuchos: exclusão e luta: do sul para a Amazônia. Tradução de Lúcia Mathilde Endlich Orth. Petrópolis: Vozes, 1993.

SCHERER-WARREN, Ilse. Redes de Movimentos Sociais. 5. ed. São Paulo: Loyola, 2011.

SCHERER-WARREN, Ilse. Das mobilizações às redes de movimentos sociais. Revista Sociedade e Estado, v.21, n.1, p. 109-130, jan./abril, 2006. Universidade Nacional de 
Brasília: Brasília. Disponível em: <http://www.scielo.br/scielo.php?pid=S0102-699220060 00100007\&script=sci_abstract\&tlng=pt>. Acesso em: 23 jun. 2017.

SCHERER-WARREN, Ilse; KRISHKE, Paulo J. Revolução no cotidiano? Os novos movimentos sociais na América Latina. Brasília: Editora Brasiliense, 1987.

SCHERER-WARREN, Ilse; LÜCHMANN, Lígia Helena Hahn. Situando o debate sobre movimentos sociais e sociedade civil no Brasil. Revista Política \& Sociedade, n. 5, p. 13-34, out.2004.

SERJE, Margarita. El mito de la ausencia del Estado: La incorporación económica de las "zonas de frontera" en Colombia. Cahiers des Amériques, n. 71, p. 95-117, 2012. Disponível em: <http://journals.openedition.org/cal/2679 ; DOI : 10.4000/cal.2679>. Acesso em: 10 jan. 2018.

SIGAUD, Lygia; ERNANDEZ, Marcelo; ROSA, Marcelo. Ocupações e acampamentos: sociogênese das mobilizações por reforma agrária no Brasil. Rio de Janeiro: Garamond, 2010 .

SILVA, José Gomes da. Caindo por Terra: crises da Reforma Agrária na Nova República. São Paulo: Busca Vida, 1987.

SILVA, José Gomes da. Buraco negro: a Reforma Agrária na Constituinte de 1987-88. Rio de Janeiro: Paz e Terra, 1989.

SILVA, Ricardo Gilson da Costa. Amazônia globalizada: da fronteira agrícola ao território do agronegócio - o exemplo de Rondônia. Confins, n. 23, 2015. Disponível em: <http:// confins.revues.org/9949>. Acesso em: 10 mar. 2018.

SODRÉ, Nelson Werneck. Formação Histórica do Brasil. São Paulo: Editora Brasiliense, 1962.

SOUZA FILHO, Carlos Frederico Marés. A função social da terra. Porto Alegre: Sergio Antônio Fabris, 2003.

SOUZA, Jessé. A Elite do atraso: da escravidão à Lava jato. Rio de Janeiro: Leya, 2017.

SOUZA, Murilo Mendonça Oliveira de. Luta, territorialização e resistência camponesa no leste rondoniense (1970-2010). 2011. Tese (Doutorado em Geografia) - PPG em Geografia, Universidade Federal de Uberlândia, 2011.

SPIVAK, GAyatri Chakravorty. Pode o subalterno falar? Tradução de Sandra Regina Goulart Almeida, Marcos Pereira Feitosa e André Pereira Feitosa. Belo Horizonte: Editora UFMG, 2010.

STEINBECK, John. As vinhas da Ira. Tradução de Herbert Caro e Ernesto Vinhaes. Rio de Janeiro: Record, 2013. 
TEDESCO, João Carlos. Terra, Salário e Família: ethos e racionalidade produtiva no cotidiano camponês. 1998. Tese (Doutorado em Sociologia) -PPG em Sociologia, Unicamp, Campinas, 1998.

THÉRY, Hervé, Rondônia: mutações de um Território federal na Amazônia federal. Curitiba: SK Editora, 2012.

TOURAINE, Alain. Poderemos viver juntos? Iguais e diferentes. Tradução de Jaime A. Clasen e Ephraim F. Alves. Petrópolis: Vozes, 1998.

TURCHI, Lenita Maria. A colonização Dirigida no Processo de Expansão e ocupação da Fronteira Agrícola. Revista de Economia Rural. Brasília/DF, v.19, p. 92-125, 1981.

VELHO, Otávio Guilherme. Frentes de Expansão e Estrutura Agrária. Rio de Janeiro: Zahar, 1972.

WOLFORD, Wendy. Participatory democracy by default: land reform, social movements and the state in Brazil. The Journal of Peasant Studies, v. 37, n. 1, January 2010, p. 91-109.

WOORTMANN, Klass. “Com parente não se neguceia”: o campesinato como ordem moral. Anuário Antropológico, n.87. Brasília (UNB): Tempo brasileiro, 1990. 


\section{Sobre o autor}

Afonso Maria das Chagas é brasileiro, Professor do Magistério Superior na Fundação Universidade Federal de Rondônia.. Lotado no Departamento de Ciências Sociais. Tem Doutorado em Ciência Política pela UFRGS (Universidade Federal do Rio Grande do Sul), Mestrado em Direito Público pela UNISINOS (Universidade do Vale do Rio dos Sinos), Especialização em Processo Civil pela UNISUL (Universidade do Sul de Santa Catarina) e graduação em Direito pela UNIR (Universidade Federal de Rondônia), em Teologia pela PUC-PR e em Filosofia pela IFITEME. 
